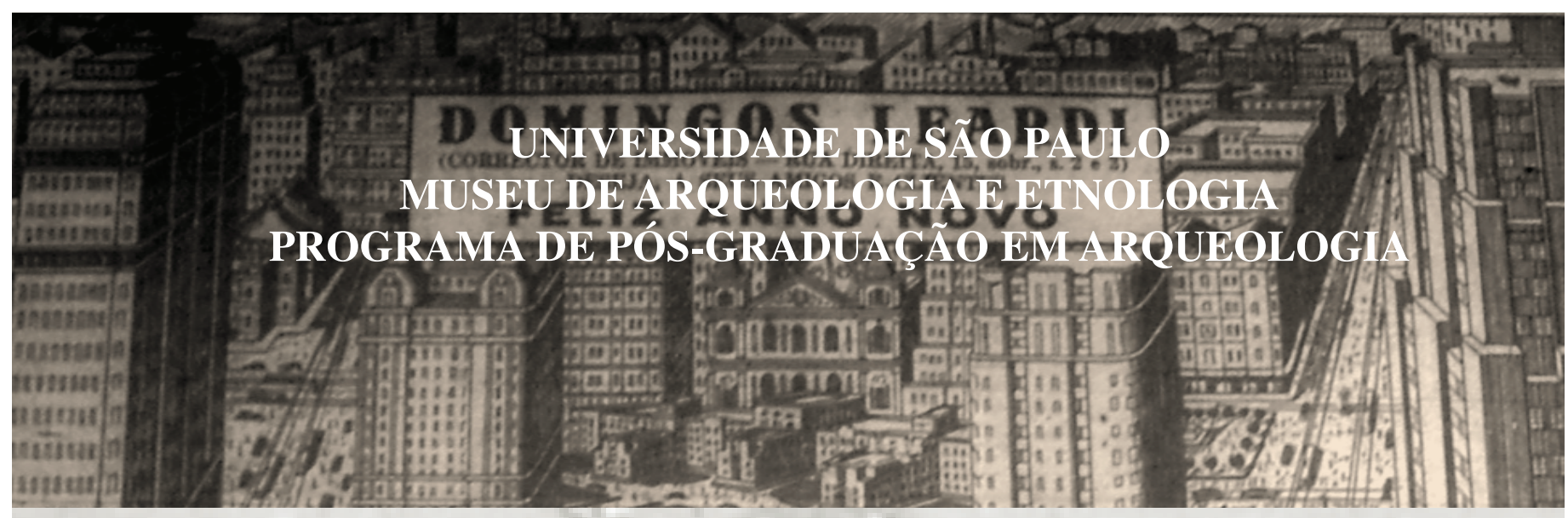

\title{
LOUÇA BRANCA PARA A PAULICÉIA: ARQUEOLOGIA HISTÓRICA DA FÁBRICA DE LOUÇAS SANTA CATHARINA / IRFM - SÃO PAULO E A PRODUÇÃO DA FAIANÇA FINA NACIONAL (1913 - 1937)
}

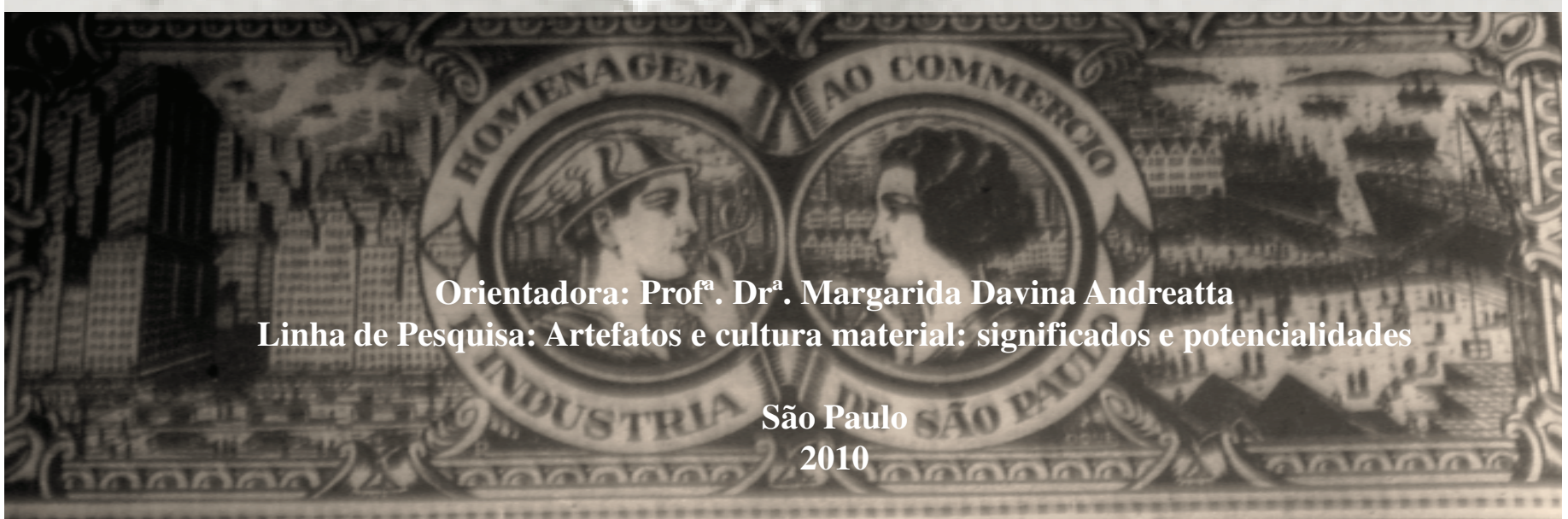




\title{
UNIVERSIDADE DE SÃO PAULO MUSEU DE ARQUEOLOGIA E ETNOLOGIA PROGRAMA DE PÓS-GRADUAÇÃO EM ARQUEOLOGIA
}

LOUÇA BRANCA PARA A PAULICÉIA:

\author{
ARQUEOLOGIA HISTÓRICA DA FÁBRICA DE LOUÇAS SANTA \\ CATHARINA / IRFM - SÃO PAULO E A PRODUÇÃO DA FAIANÇA \\ FINA NACIONAL (1913 - 1937)
}

Rafael de Abreu e Souza

Dissertação apresentada ao Programa de PósGraduação em Arqueologia do Museu de Arqueologia e Etnologia da Universidade de São Paulo, para obtenção do título de Mestre em Arqueologia.

Orientador: Prof. Dra. Margarida Davina Andreatta

Linha de Pesquisa: Artefatos e cultura material: significados e potencialidades

São Paulo

2010 


\section{RESUMO}

SOUZA, R. A. Louça branca para a Paulicéia: Arqueologia Histórica da Fábrica de Louças Santa Catharina / IRFM - São Paulo e a produção da faiança fina nacional (1913 - 1937). 2010. Dissertação (mestrado) - Museu de Arqueologia e Etnologia, Universidade de São Paulo, São Paulo, 2010

O ano era 1912, e um imigrante italiano e um grupo de irmãos provindos da aristocracia fazendeira encontraram-se nos escritórios sobre o famoso Café Guarany, no pulsante coração comercial da cidade, o Triângulo, para combinarem os trâmites à fundação da primeira fábrica de louças em faiança fina do país, em moldes industriais, produção em série e larga escala, no, então, rural bairro da Lapa. Assim teve início a história da Fábrica de Louças Santa Catharina, posteriormente Indústrias Reunidas Fábricas Matarazzo (IRFM) São Paulo, que abarrotou a cidade de São Paulo com toneladas de louças brancas ou decoradas feitas em seus inúmeros fornos. Fundada no fulcro dos projetos de modernização para a Paulicéia tão desvairada, fábrica e louças dialogaram com as conjunturas das quais eram agência e estrutura. Formas e motivos espalharam-se pelos diversos consumidores da cidade, desbancando, muitas vezes, o monopólio da louça branca estrangeira, da qual se diferenciou produzindo-se segundo lógicas e tecnologias locais.

Esta pesquisa baseia-se na análise do sítio arqueológico Petybon, no bairro da Lapa, cidade de São Paulo, região da Água Branca/Vila Romana, escavado no ano de 2003, que revelou ter sido o local de uma antiga fábrica de louças em faiança fina, inaugurada em 1913, fundada meio à maciça imigração italiana e o financiamento das indústrias pelo capital do café. Funcionou até 1937, já pertencente aos Matarazzo que a adquiriram em 1927. O local tem extrema relevância não apenas no contexto da Arqueologia Urbana no Brasil, como também enquanto exemplar dos primórdios da industrialização do país e da história da produção da louça nacional, parcamente tratada pela literatura, pouco valorizada e identificada, apesar de sua frequiência nos sítios arqueológicos do século XX.

PALAVRAS-CHAVE: Faiança fina; Louça Brasileira; Fábrica de Louças Santa Catharina; Matarazzo; Arqueologia Histórica; São Paulo República 


\begin{abstract}
SOUZA, R. A. Industrial pottery for São Paulo city: Historical Archeology of the Santa Catharina Pottery Factory / IRFM - São Paulo and the production of the national refined earthenware (1913 - 1937). 2010. Dissertação (mestrado) - Museu de Arqueologia e Etnologia, Universidade de São Paulo, São Paulo, 2010
\end{abstract}

The year was 1912, and an Italian immigrant and a group of brothers, drawn from an Aristocratic family farmer, met at an office above the famous Guarany Coffee House, in the beating heart of the city, the Triangle, to establish a fellowship and combine the procedures to the foundation of the first refined earthenware factory in the country, based on an industrial manufacturing, by a mass and large scale production, at the rural district of Lapa. That was the beginning of the history of Santa Catharina Pottery Factory, later Matarazzo United Manufacturing - São Paulo, who crammed São Paulo city with tons of white or decorated pottery, made in its many kilns. Forged at the center of modernizations project for the city, the pottery and factory dialogue with the contexts whose were agency and structure. Forms and motifs spread out by various consumers, beating, often, the foreign pearlware and whiteware monopoly, from whom it was distinguished by organizing itself according with its own logic and technology development.

This research is based on the analysis of Petybon archaeological site, in the neighborhood of Lapa, São Paulo, at the region known as Água Branca / Vila Romana, excavated in 2003, which appeared to have been the site of one of the firsts refined earthenware factories, opened at 1913, founded through the massive Italian immigration and the financing of industries by coffee profits. Worked until 1937, then belonging to the Matarazzo Family, who acquired it in 1927. The site is extremely important not only in the context of Brazilian Urban Archeology, but also as an example of the early industrialization in Brazil and the history of national pottery industry, barely treated by literature, almost unknown and unappreciated, despite its frequency at Brazilian archaeological site from the $20^{\text {th }}$ century.

KEY-WORDS: Refined Earthenware; Brazilian Industrial Pottery; Santa Catharina Factory; Matarazzo Familiy; Historical Archaeology; Republican São Paulo 


\section{RESUMEN}

SOUZA, R. A. Loza blanca para la ciudad de São Paulo: Arqueología Histórica de la Fábrica de Lozas Santa Catharina / IRFM - São Paulo y la producción de loza fina nacional (1913 - 1937). 2010. Dissertação (mestrado) - Museu de Arqueologia e Etnologia, Universidade de São Paulo, São Paulo, 2010

Era el año 1912, y un inmigrante italiano y un grupo de hermanos, provenidos de una família aristocrática de hacienderos, se reunieron en una oficina sobre el famoso Café Guarany, en el corazón de la ciudad, el Triángulo, a arreglar los procedimientos para la fundación de la primera fábrica de loza fina del país, con produduccíon industrial en gran escala, ubicada en el districto rural de Lapa. Así comenzó la história de la Fábrica de Lozas Santa Catharina, despúes Industrias Manufactureras Matarazzo - São Paulo, que abarrotaron la ciudad de São Paulo, con toneladas de loza blanca o decorada, hecha en sus variados hornos. Fundada medio a los proyectos de modernización para la ciudad, fábrica y cerámica se relacionan con los contextos de los cuales fueron agencia y estructura. Formas y motivos diferentes distribuidos para los consumidores de la ciudad, superaron, a menudo, el monopólio de la loza blanca extranjera, de la cual distienguese por su propia lógica y desarrollo tecnológico.

Esta investigación se basea en el análisis del yacimiento Petybon, en el barrio de Lapa, São Paulo, la región de Água Blanca / Vila Romana, excavado en 2003, que hubiera sido el sítio de una antígua fábrica de loza, inaugurada en 1913, fundada junto a la masiva inmigración italiana y la financiación de las industrias nacionales con el capital del café. Estuvo abierta hasta 1937, ya pertenecente a la família Matarazzo, que la adquirieron en 1927. El sítio es importante no sólo en el contexto de la Arqueología Urbana en Brasil, sino también como un ejemplo de la temprana industrialización del país y de la história de producción de la loza industrial nacional, mal tratada por la literatura, poco valorada y reconocida, a pesar de su frecuencia en los yacimientos del siglo XX.

PALAVRAS-CHAVE: Loza fína; Loza industrial brasileña; Fábrica de Loza Santa Catharina; Matarazzo; Arqueología Historíca; São Paulo República 


\title{
RESUMÉE
}

\author{
SOUZA, R. A. Faïence pour la ville de São Paulo: Archeólogie Historique de la Fabrique \\ de Cerámique Santa Catarina / IRFM - São Paulo et la production de la faïence \\ nationale (1913 - 1937). 2010. Dissertação (mestrado) - Museu de Arqueologia e Etnologia, \\ Universidade de São Paulo, São Paulo, 2010.
}

L'année était 1912, un immigrant italien et une groupe de frères provenants de l'aristocratie fermière se rencontrent aux bureaux situés sur le fameux Café Guarany, dans le pulsant cœur commercial de la ville, le Triangle, afin de se mettre en accord sur les procédures de fodation de la première fabrique de vaisselles en faïence fine du pays, à utiliser les procédés industriels, production en série et à large échelle, à se situer dans le quartier de Lapa, qui à cette époque-là était un quartier rural. Ainsi a débuté l'histoire de la Fabrique de Vaisselle Santa Catarina qui, à une date postérieure, fera partie des Industries Reunis Fabriques Matarazzo (IRFM) - São Paulo, qui a comblé la ville de São Paulo de vaiselles blanches ou décorées faites par leurs nombreux fours. Crée dans un contexte des projets de modernisation pour la ville de São Paulo, fabrique et céramique ont établi un dialogue avec les conjonctures desquelles elles étaient à la fois agentes et structures. Formes et motifs se sont eparpillés par les différents consommateurs de la ville, au point même de, bien des fois, remplacer le monopole de la vaisselle blanche étrangère dont elle s'était différenciée en se faisant produire à partir de logiques et de technologies locales.

Cette recherche est basée sur l'analyse du site archéologique Petybon, localisé dans le quartier de Lapa, à la ville de São Paulo, dans la région Água Branca/Vila Romana, qui a été fouillé en 2003 et identifiée comme lieu d'une ancienne fabrique de faïence. Fabrique inaugurée en 1913, fondée au milieu d'une immigration italienne massive et aussi du financement des industries par le capital provenant du café. Cette fabrique a été en fonctionnement jusqu'en 1937, à ce moment-là appartenant déjà aux Matarazzo qui l'avaient acquis en 1927. Lieu d'extrême importance non seulement dans le cadre de l'Archeólogie Urbaine au Brésil, mais aussi comme un exemple primordial du processus d'industrialisation du pays et de l'histoire de la production de la vaisselle nationale - sujet très peu traité, tandis que la faïence, elle-même peu valorisé, soit souvent présente dans les sites archeólogiques du XXème siècle.

Mots-Clés: Faïence; Vaisselle Brésilienne; Fabrique de Cerámique Santa Catarina; Matarazzo; Archéologie Historique; São Paulo Republique 


\section{SUMÁRIO}

Apresentação (ou por uma Arqueologia Urbana Antrópica)

1. Programa de Prospecções e Resgate Arqueológico do sítio Petybon escavando uma unidade fabril e um aterro de cerâmica na cidade

1.1. Programa de prospecções e resgate do sítio arqueológico Petybon

1.2. Fábia, Aurélia, Coriolano e Catão na Vila Romana: evolução urbana e ocupação

1.3. Um aterro de louças na cidade

2. Atributos, categorias de análise e artefatos do sítio Petybon

3. Produção: particularidades e especificidades na esfera produtiva

3.1. Processo produtivo na Fábrica de Louças Santa Catharina / IRFM - São

Paulo: tecnologias nacionais e estrangeiras particularizando a louça em faiança fina nacional

3.1.1. A cadeia operatória de produção das louças do sítio arqueológico Petybon

3.1.2. Na longa duração da mercantilização e da industrialização: a

Fábrica Santa Catharina / IRFM - São Paulo e a instalação das fábricas de faiança fina em São Paulo

3.1.3. Louceiros Paulistas: trabalhadores e proprietários da Fábrica de Louças Santa Catharina / IRFM - São Paulo

3.2. Por uma louça asséptica: vidrados, gretamento e discursos higienistas

3.3. Defeitos de produção e o significado dos defeitos: desafios produtivos e o consumo das louças "tipo popular"

3.4. Escritos na Argila: Arqueologia, Epigrafia e as inscrições do sítio Petybon - ou por uma Arqueologia Industrial da produção, do trabalhador e do tempo

3.5. Na mão do oleiro: as impressões digitais nas louças brancas da cadeia 
produtiva do sítio Petybon

4. Consumos específicos em conjunturas particulares

4.1. Tigelas da tradição: formas e volumes das louças brasileiras

4.1.1. O ritual do cafezinho: hábito de sociabilidade com xícaras e 309 tigelas

4.2. Margaridas e "espigas de Trigo" nos motivos, técnicas e padrões decorativos das louças em faiança fina da Fábrica Santa Catharina / IRFM - São Paulo

4.3. As louças na publicidade dos periódicos $O$ Estado de São Paulo e $O$ Correio Paulistano

4.4. Louça e goiabada: como as louças (des)aparecem nos inventários da Grande São Paulo da primeira metade do século XX

5. Considerações finais a um novo paradigma de modernidade para a cidade de São Paulo: episteme da louça branca brasileira

Anexo 2: Catálogo de louças do sítio Petybon (CD-ROM) 


\section{APRESENTAÇÃO \\ (OU POR UMA ARQUEOLOGIA URBANA ANTRÓPICA)} ... raramente a louça é atirada de grandes alturas; é uma
das mais raras ações humanas. Precisa haver ao mesmo
tempo uma casa muito alta e uma mulher tão impulsiva e
violenta que atire o seu jarro ou pote pela janela sem
pensar em quem passa lá em baixo. Louça quebrada era
fácil de encontrar, mas quebrada em algum prosaico
acidente doméstico, sem intenção ou finalidade...

(Virginia Woolf, Objetos Sólidos)

Já não coleciono selos. Agora coleciono cacos de louça quebrada há muito tempo.

Cacos novos não servem

Brancos também não.

Têm de ser coloridos e vetustos desenterrados - faço questão - da horta Guardo uma fortuna em rosinhas estilhaçadas restos de flores não conhecidas.

(Coleção de cacos, Carlos Drummond de Andrade)

Pina-Cabral percebeu, em suas pesquisas, que havia algo na cerâmica popular portuguesa que ninguém percebera antes e que não constava em registros escritos nem em qualquer outra fonte: refere-se à vasta tradição local da indústria cerâmica de artefatos em forma de falo, em Portugal (1993: 105). O antropólogo notou que muitos dos aspectos da cultura popular portuguesa não eram vistos pelos olhos dos pesquisadores e que este tipo de cerâmica foi ignorada, mesmo existindo há muito tempo. São os olhos dos cientistas que vêem apenas aquilo que querem ver, já nos mostrava os Annales desde o final dos anos 1920 (BURKE 1986). Para a arqueologia, Gallay (2002: 6) afirmou que "só vemos aquilo para o qual nos preparamos para ver". Se não estamos, portanto, preparados para a louça brasileira, não a vemos. Fica a dúvida se a faiança fina nacional realmente não estava no sítio ou não foi diagnosticada por não estarmos preparados. Esta deficiência na identificação dos materiais no registro arqueológico (MEJÍA \& THERRIEN 2001/2002: 201) gerou a necessidade da produção de arqueografias.

Os questionamentos de Pina-Cabral nortearam algumas das questões da presente pesquisa em torno da louça em faiança fina, mais barata, mais popular, de fabricação brasileira, que está nos sítios arqueológicos, mas que é pouco estudada e pouco valorizada. 
Parece haver, na verdade, uma ausência de pesquisas sobre o tema, não apenas no âmbito brasileiro, mas no que concerne a America Latina em geral. Tenho a impressão, às vezes, de que há uma supervalorização da louça inglesa em detrimento das cerâmicas locais nas abordagens da Arqueologia Histórica e que não se percebe que, se esta visão é pautada nas idéias provindas das obras de Gilberto Freyre, elas também são devedoras da "relação de amor", como chamou a atenção Pallares-Burke (1997), de Freyre com a Inglaterra. Há que se ter em mente que objetos e sujeitos históricos emergem de construções discursivas (RAGO 2004). Por isso este trabalho é uma proposta de mudança de escalas de observação, a fim de sugerir mudanças em interpretações (SASSAMAN 2005: 335).

Para Therrien, Jaramillo Pacheco e Salamanca (2003: 157), as noções derivadas de ideologias modernas, na America Latina, fizeram ver processos de "inovação" acima da "tradição", de modo que "inovar" foi encarado como a introdução de práticas européias, assimiladas como dominação e, conseqüentemente, imposição, sem que se questionasse muito os sentidos da cultura material em cenários de comunicação intercultural. Até o momento, por exemplo, existem apenas dois estudos arqueológicos, em todo o continente, sobre fábricas de louça branca, sendo um deles na Colômbia, de autoria da própria Monika Therrien, e um no Paraná, o mestrado de Martha Morales sobre a Fábrica Colombo.

No universo das cerâmicas de produção brasileira, ou de produção local, o que é, afinal, essa louça branca? O que é este artefato tão cotidiano, relativamente comum, que faz parte de nosso dia a dia e ao qual não prestamos muita atenção? Nem mesmo percebemos que, ao estabelecer uma relação de catacrese, em língua latina, com a cerâmica, estamos aproximando nosso corpo do corpo cerâmico, tal como fazem muitos povos estudados em sua alteridade em relação a nós, "sociedade ocidental". Para Orser, a análise destes artefatos "banais" propiciaria nossa entrada em um mundo fluido de significados, desafiaria interpretações mais simplificadas (2005: 67). Mullins, estudando a presença dos bibelôs em sítios arqueológicos estadunidenses, por exemplo, acabou mostrando que nem todo artefato tido como mais "fino" (como as louças) é um mero índice da posição social de seu proprietário (ORSER 2005: 66-67). A louça brasileira, banal e corriqueira nos sítios arqueológicos, sob outro prisma, pode mudar a interpretação sobre o contexto do sítio, sua cronologia e os hábitos e características daqueles que as utilizaram. Exemplo disso é a própria porcelana brasileira, muitas vezes descrita como um objeto não identificado, ou a 
faiança fina nacional que, apesar de difícil identificação, é freqüentemente tomada como estrangeira.

Tendo em mente esta ausência de pesquisas sobre o tema, comecei a desenvolver uma pesquisa, ainda na graduação, na Universidade Estadual de Campinas, pautada no sítio arqueológico Petybon, no bairro da Lapa, em São Paulo, com a finalidade de entender melhor um material tão pouco estudado e muito negligenciado nas pesquisas arqueológicas, a louça brasileira, tendo em vista dúvidas e questionamentos de maior âmbito que foram germinando durante os primeiros anos de minha formação em História, semeados pela influência das abordagens da teoria pós-colonial e da arqueologia cubana. Notei também que abordar os primórdios da história da louça branca no Brasil submergir-me-ia aos aspectos de popularização e barateamento deste produto, que passou a ser utilizado por camadas médias e pobres da cidade que antes não compravam, ou não consumiam tanto, louça em faiança fina. Abordar arqueologicamente "aspectos da cultura que não são escritos, os objetos, as coisas, o mundo material usado e transformado pelos homens" (FUNARI 1992: 7), no âmbito do Brasil e da América Latina, a partir do sítio Petybon, e com determinados olhares e abordagens pós-colonialistas, permitiu ir além de uma documentação escrita emanante (do suposto) "centro" (CORZO 2005: 48). Uma vez que "a descrição e a interpretação de vestígios materiais em Arqueologia Histórica são absolutamente impregnados por discursos de identidades derivados das fontes escritas" (JONES 2005: 30), tentei enveredar pela crítica a esta relação no que diz respeito ao que é descrito como "moderno" pelas fontes e o que se encontra na época da modernidade da cidade, assim como realizar questionamentos às categorias derivadas de documentos escritos como "classe" ou "aburguesamento" - como disse Stuart Hall, "os interesses materiais por si só não tem necessariamente uma filiação a classes” (BHABHA 2007: 56). Este trabalho pretende enveredar pelos meandros das tentativas contradiscursivas (SAID 2003: 97) através da interpretação e análise da louça em faiança fina nacional.

Já que toda ação humana deixa alguma marca ou está associada à utilização de algum tipo de instrumento que permanece no solo sob a forma de "registro material" (DEMARTINI \& BRAGA 2005), todo ser humano pode ser, teoricamente, estudado pela Arqueologia. Como nos mostrou Jean-Pierre Warnier, "desde o nosso nascimento até a morte, e mesmo além, nós não escapamos da cultura material, nem mesmo por um breve 
momento. Nas sociedades industriais, sua impregnação vai além das medidas e contrasta com a indigência dos instrumentos de que dispomos para analisá-la" (2003: 6). Isso também não quer dizer que os objetos sejam reflexos passivos da sociedade, mas, sim, mediadores e direcionadores de atividades humanas e relações sociais (FUNARI 2001: 33).

Lembro que uma abordagem mais pós-processualista neste ponto não significa a adoção de uma bandeira pós-processualista nessa pesquisa. Assumir veementemente uma corrente teórica, quiçá, por vezes, limite a capacidade de interpretação que outras ferramentas teóricas poderiam fornecer. Seria como colocar óculos que nos fizessem ver apenas aquilo que o grau-teórico possibilita. Pelo contrário. Acredito que as correntes teóricas têm muito a acrescentar numa pesquisa, de um modo ou de outro (HODDER 1999: 17), uma vez que o conhecimento arqueológico é subjetivo e não possibilitaria generalizações universais ou verdades absolutas (REIS 2003: 71). Entretanto, adotei, sim, um pano de fundo, e um modo de ver o mundo, que é bastante devedor de um corpo teórico específico, destarte suas mais variadas linhas, conhecido como pós-colonialismo, seja aquele dos primeiros teóricos como Ranajit Guha, Partha Chaterjee, seja dos estudos desenvolvidos posteriormente por Said, Bhabha, Hall, Chakrabarty e outros.

$\mathrm{Na}$ América Latina, a abordagem pós-colonial é utilizada na História e na Sociologia, aproximando-se de trabalhos como os de Monjolo e Canclini, mas pouco pela Arqueologia (FERREIRA 2007). Algo que só renderia frutos no intuito de descolonizar os imaginários produzidos sobre o Brasil, intervindo no interior de um sistema de representações (SAID 2007), ou, ao menos, corroboraria um papel mais político da arqueologia em trabalhar as identidades nacionais do ponto de vista da crítica à paradigmas como "centro - periferia" ou noções de "cópia". Algumas destas leituras caracterizam-se, para Lúcio Meneses, como interpretação difusionistas, pautadas em "variações miméticas das estruturas sociais, culturais e políticas ditadas pela Europa" (FERREIRA 2007: 7) que desconsideraram contextos de apropriação e representação historicamente situados. Uma vez que a louça em faiança fina nacional não é cópia, ressalto sempre sua originalidade, mas, lembro aqui, que atento à ingenuidade de uma criação a partir do nada (SCHWARZ 2005), já que este artefato é devedor de um ato de repetição e de uma diferença que o define, por isso não idêntica a louça inglesa (BHABHA 2007:157).

Implicações desta alçada foram questionadas uma vez pela Arqueologia Social 
Latino Americana e também com este intuito tentei, na medida do possível, prestigiar os arqueólogos latino-americanos, lendo os trabalhos que encontrei, destarte a sabida dificuldade no acesso, em geral porque se está conformando no país, de algum modo, leituras específicas das cosmologias do capitalismo que aqui se criaram e desenvolveram, lembrando Sahlins (2004), e interpretações das expressões locais da cultura material que pouco tem a ver com o que ocorreu em contextos cuja conjuntura foi bastante diversa, como a estadounidense. Logo, debati com as constantes problemáticas sobre as proposições em torno de status socioeconômico e cronologias das louças pautadas em pressupostos estrangeiros, questionando o alcance de elementos indicadores de cronologia e status em um contexto tão diverso e complexo como uma cidade (THERRIEN, JAMARILLO PACHECO \& SALAMANCA 2003: 162).

Esta dissertação sintetiza quase seis anos de pesquisas e reflexões em torno do sítio arqueológico Petybon, no interior da zona metropolitana de São Paulo. Quem passa pelo lugar atualmente não imagina que sob um condomínio de alto padrão estão os remanescentes da primeira fábrica de louça em faiança fina do país, em moldes industriais, e que sob a quadra de tênis estão centenas de milhares de fragmentos e peças inteiras de cerâmica branca das primeiras décadas do século XX. Aliás, este é, também, um trabalho sobre o século XX, um século que é tão pouco analisado quanto ignorado pela Arqueologia Histórica, em geral. Parece haver um acordo silencioso entre o que é etnoarqueológico e o que é objeto da Arqueologia Histórica de modo tão pouco claro que acabou eliminando as reflexões e a cultura material (de maneira, inclusive, literal) do breve século, lembrando Eric Hobsbawm (2008).

Quanto à narrativa impingida e à organização da dissertação, alguns pontos devem, ainda, ser esclarecidos. O primeiro deles, e logo possíveis leitores perceberão, é que tentei eliminar as marcas de impessoalidade típicas do discurso academicista e não me utilizei da suposta objetividade atingida em prol de uma aparente "esquizofrenia" do sujeito acadêmico, impessoal e teoricamente intangível; é a crítica de Foucault (2007: 26) em prol do autor como "princípio de argumento do discurso". Para além de pressupor, sobre o discurso acadêmico, um embate entre o doxológico e o epistêmico (FUNARI 1992), pauteime nas abordagens que sugerem ser possível a construção do conhecimento "por meio de todos os instrumentos da linguagem humana, de maneira que um trabalho de pesquisa pode 
oferecer a oportunidade de exercitar a individualidade criadora e de fazer algo que satisfaça aos anseios do estudioso, ao invés de realizar um trabalho que segue, inflexivelmente, as regras de procedimento impostas como padrão, inserindo-se em uma formação discursiva e apropriando-se de um discurso que não condiz com os atuais almejos, porque todos fazem assim, exige-se assim" (CORREA 2004). Lembrando as imprescindíveis discussões de Hayden White (1991) sobre a narrativa na História e na Literatura, optei por escrever a dissertação em primeira pessoa.

Carl Axel Moberg, um dos expoentes da arqueologia sueca, afirmou, nos anos 1960, que "a Arqueologia não é apenas uma disciplina técnica, instrumento de... Não é uma 'ciência da pá' e, nela, os instrumentos contam menos do que o cérebro, como nas outras ciências. Não é também uma 'procura de objetos'. O arqueólogo não anda à procura de 'antiguidades', mas de conhecimentos (....) Não procura também definições de uma qualquer cultura material, porque a noção de cultura é já propriamente falando imaterial. $\mathrm{Na}$ verdade, as questões pelas quais o arqueólogo procura resposta concernem exatamente o imaterial" (MOBERG 1986: 60). O interesse maior nesta pesquisa não são os objetos em si, mas o que eles podem dizer das pessoas e da sociedade que os usaram e produziram, afinal. Dessa forma, discorri sobre a produção da louça em faiança fina no Brasil (seu processo de fabricação em grande escala, em moldes industriais, pela primeira vez), particularmente em São Paulo, seguido de sua conseqüente popularização, adentrando as discussões das demandas pelo produto e de alguns de seus possíveis consumidores, também os componentes dos grupos pobres e médios da cidade no início do século XX.

O discurso de uma São Paulo, do início do século, que se apresenta como moderna, urbanizada, europeizada, elitista, deixou de fora muitos de seus principais componentes e inclusive elaborou políticas que visavam apagar o que era considerado não-moderno, ou seja, aquilo que parecia ligado a hábitos coloniais, rurais, etc. A partir disso propus uma abordagem mais crítica quanto a algumas teses em voga na Arqueologia Histórica e na História como a da "ideologia dominante", já que grupos mais pobres também possuíam aspectos culturais próprios, não sendo/querendo ser "cópia” de uma elite ou "desvio" de um modelo original que pressupõe uma visão rígida de cultura. Aspectos que estão no cerne de questões como as práticas da ação, e não apenas da re-ação, como podem ser vistos nos trabalhos de Chalhoub (2006: 99) sobre as "classes perigosas" no Rio de Janeiro 
oitocentista.

Enquanto trabalho de Arqueologia Urbana, não posso deixar de explicitar algumas das razões que me fizeram enveredar pela história da cidade de São Paulo, através da louça em faiança fina, e que resultaram na produção do Capítulo I, que apresenta aspectos do trabalho de campo, da evolução urbana da área da Fabrica Santa Catharina através do uso de cartas e plantas, e da estratigrafia do sítio Petybon, focando sua mais definidora característica: o fato de ser composto por (ou ser) um grande aterro de louças. Para além de uma resposta adaptativa, para Zarankin (1994: 33) o uso urbano é também uma utilização particular do solo e do espaço em seu contexto específico.

Estendi-me um pouco mais neste capítulo, apesar de não realizar grandes incursões teóricas sobre a Arqueologia Urbana, porque nos últimos anos o Brasil assistiu a um retorno do arqueólogo à cidade, também no âmbito acadêmico, mas especialmente no âmbito da Arqueologia Preventiva. Isto levantou novas questões em torno do próprio fazer da ciência arqueológica que são importantes ressaltar.

A região da grande São Paulo é formada por 39 cidades, em intenso processo de conurbação, referente ao efeito da extensão da capital paulista, formando com seus municípios vizinhos uma mancha urbana contínua. Com 19.616.060 habitantes, é o maior centro urbano do Brasil e da América do Sul, e a sexta maior área urbana do mundo, ocupando $7.944 \mathrm{~km}^{2}$, com área urbanizada de $2139 \mathrm{~km}^{2}$, o que corresponde a menos de um milésimo da superfície brasileira e pouco mais de 3\% do território paulista.

Uma consulta aos 269 relatórios ${ }^{1}$ disponíveis na $9^{\text {a }}$ Regional do IPHAN - São Paulo (até abril de 2009), concernentes a variados projetos, dentre prospecções arqueológicas e vistorias, diagnósticos, peritagens e outras ações não-interventivas levados a cabo na região da grande São Paulo, mostrou o maciço predomínio deste último tipo (70\%) em comparação a atividades interventivas (30\%). O levantamento mostrou também que, desde o início da arqueologia na região metropolitana, nos anos 1970, 35 profissionais exerceram suas atividades ${ }^{2}$, distribuídos entre 78 instituições e empresas, além de 17 profissionais que atuaram de modo autônomo.

\footnotetext{
${ }^{1}$ Os dados que compõe essa rápida avaliação são resultado da leitura dos relatórios e projetos de arqueologia depositados na $9^{a}$ Regional do IPHAN - São Paulo, no âmbito da parceria efetivada pelo termo de cooperação entre a empresa Zanettini Arqueologia e o IPHAN.

${ }^{2}$ Não foram contabilizadas equipes e sim coordenadores de projetos.
} 
O que chamou atenção, pressupondo algumas abordagens no âmbito da Arqueologia Urbana, foi o grande predomínio de vistorias, sem intervenções em sub-superfície, que resultaram em finalizações de projetos, ou seja, após vistorias não interventivas, o subsolo da cidade foi descartado como ente possuidor de potencial arqueológico, pautando-se em justificativas como a de que não foram encontradas as "feições originais do terreno", "meias encostas" ou outras marcas na paisagem típicas de levantamentos para sítios précoloniais ou indígenas. Isto torna aparente o enorme descompasso entre os projetos de arqueologia desenvolvidos na região metropolitana de São Paulo (referindo-se, especialmente, aos trabalhos em Arqueologia Preventiva), e as discussões teóricas e práticas (se é que são separáveis) da Arqueologia Urbana e Histórica.

Desde os anos 1980, a cidade passou a ser tratada como um grande locus arqueológico, na qual é, ela mesma, um sítio arqueológico, devendo ser realizada uma arqueologia da, para e na cidade (SALWEN 1978; STASKI 1999). O que está se realizando, porém, em grande parte da região metropolitana de São Paulo, e talvez em muitos outros centros urbanos, é meramente uma arqueologia na cidade, também sem maiores preocupações em torno da grande expressão arqueológica que é, afinal, a cidade, ou seus edifícios, na busca assídua por vestígios móveis tais quais seriam encontrados em sítios cerâmicos, por exemplo. $\mathrm{O}$ fato de a cidade ter escolhido e selecionado áreas do compartimento do planalto onde foi implantada, orientando seu desenvolvimento (AB'SÁBER 2007: 25), já é, em si, um aspecto arqueológico (aliás, sabidamente conhecido como "padrão de assentamento" a partir de uma visão regional de um conjunto de sítios [ARAÚJO 2001: 97]). Como chamou a atenção Zanettini (2004: 152), “o arqueólogo urbano não tem necessariamente que restringir suas análises aos locais que escava".

A Arqueologia Urbana surge como campo que não se desenvolve unicamente em ações diretas - sondagens e escavações do solo - mas, também, através do estudo sistemático de todo tipo de evidência material do passado, de acordo com uma metodologia científica específica segundo a qual também os edifícios e espaços construídos são analisados nos seus restos materiais (ZANETTINI 2004: 152). Se a arqueologia trata de ações humanas, expressões materiais de culturas, antropizações de meios e criação e modificação de paisagens, porque, como nota-se através da consulta aos projetos de arqueologia realizados na região metropolitana, estes trazem, em sua grande maioria, no 
âmbito de recomendações ou considerações finais, frases como "potencial arqueológico nulo" ou "sem interesse arqueológico", colocando, num mesmo patamar camadas de formação estritamente geológicas, não antrópicas, e a estratigrafia complexa dos meios urbanos?

Os 269 projetos de arqueologia desenvolvidos na região metropolitana de São Paulo estão distribuídos no tempo segundo o gráfico a seguir. A concentração de projetos no final dos anos 1970 e começo dos anos 1980 é resultado do hercúleo trabalho da Prof ${ }^{\mathrm{a}}$. Dr ${ }^{\mathrm{a}}$. Margarida Davina Andreatta (1986), envolvendo o cadastramento e a pesquisa arqueológica das chamadas "casas bandeiristas" (ZANETTINI 2005). Após uma temporada de estudos na Europa, na França, vinculada à Sorbonne e ao Musée de l'Homme, sob os auspícios de Leroi-Gourhan, e depois com os sítios paleo-cristãos em Portugal, a Prof ${ }^{a}$. Dra . Margarida retornou ao Brasil dando início a toda uma vertente francesa de escavações de sítios históricos na cidade. Nota-se, também, segundo o gráfico, dois booms de pesquisas, um em torno de 2003 e outro em 2008, coincidentes com a efetivação da Portaria 230 em 2002, e com a normativa que tornou obrigatória a realização de pesquisas arqueológicas em determinado perímetro urbano do centro da cidade de São Paulo.

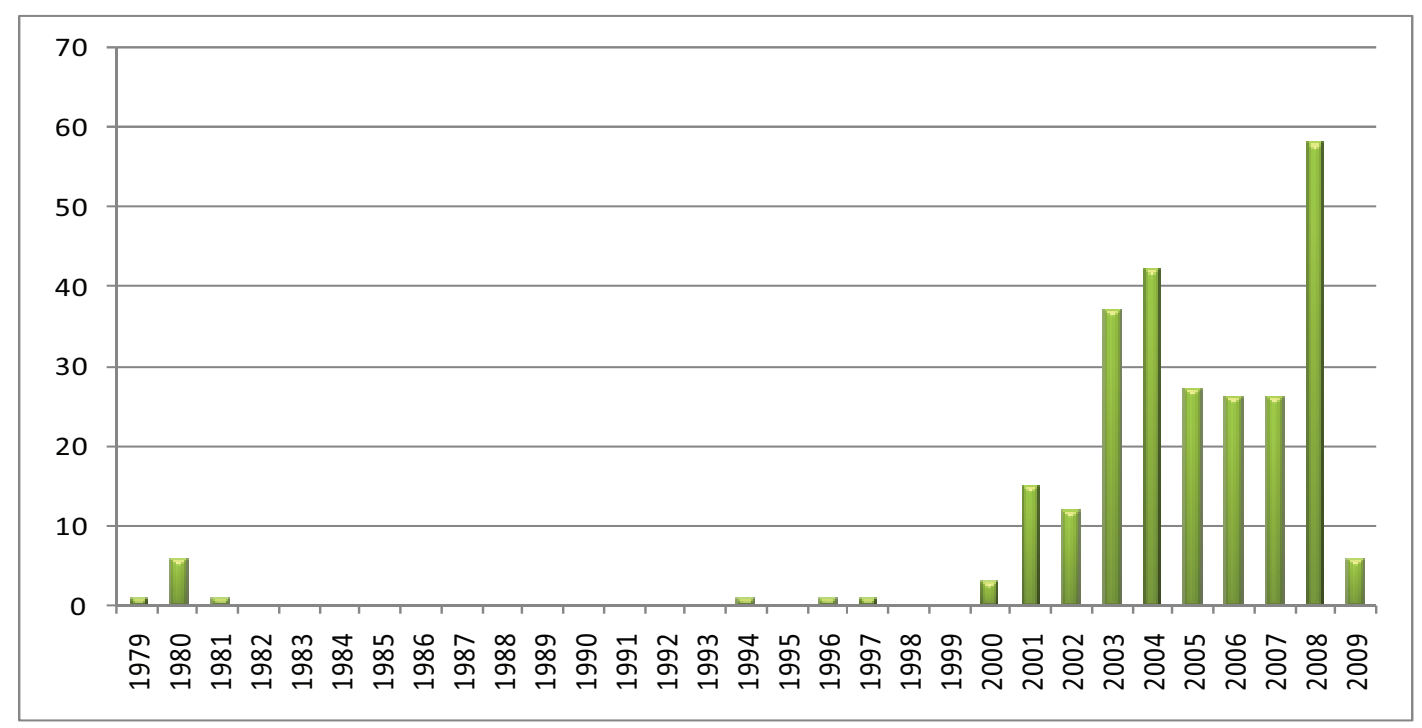

Para a cidade de São Paulo, com um total de 117 projetos, percebe-se a mesma distribuição, com o aumento significante das pesquisas arqueológicas apenas no século XXI. 


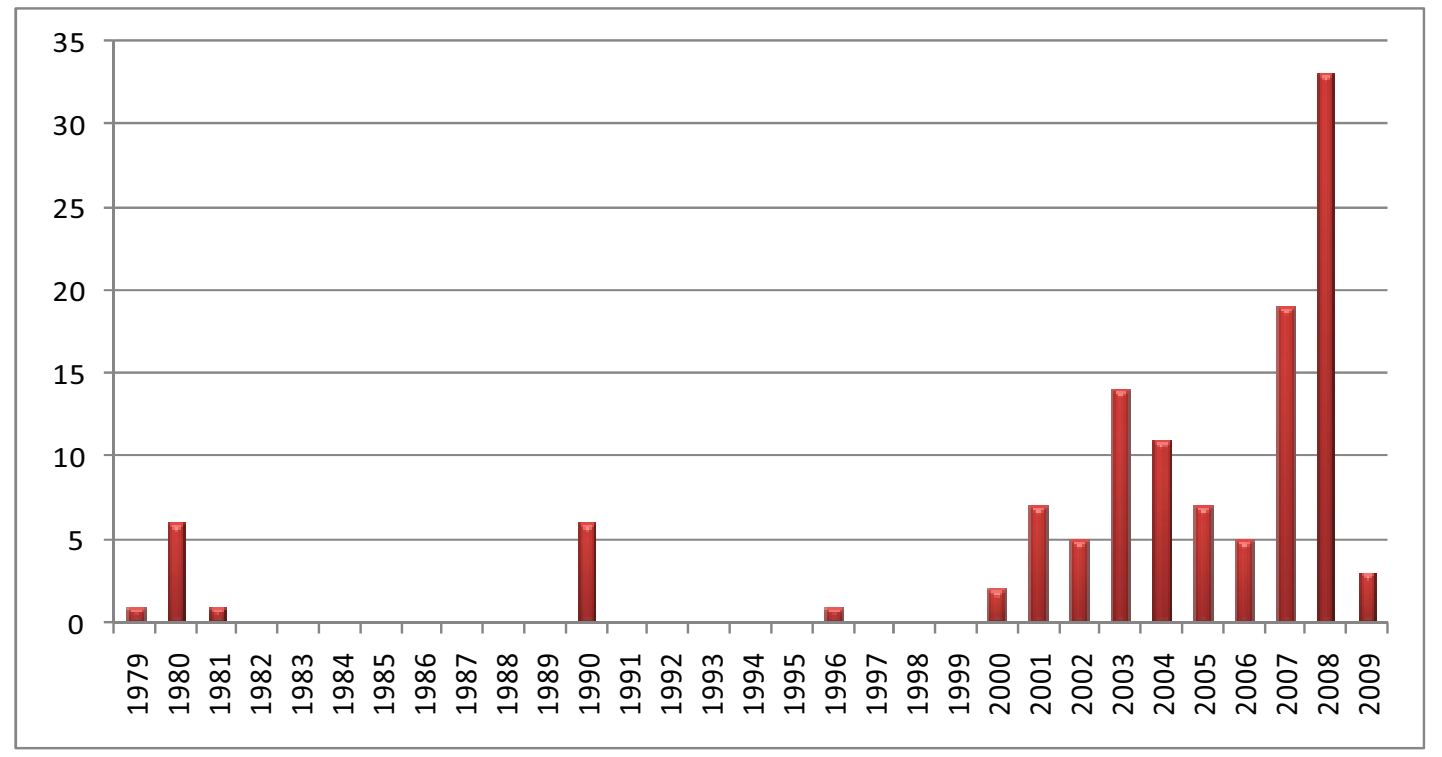

Por município da região administrativa, nota-se, a partir do gráfico abaixo, o predomínio dos projetos de arqueologia preventiva nas cidades de São Paulo, seguida modestamente por Mogi das Cruzes, Santo André, São Bernardo e Mauá.

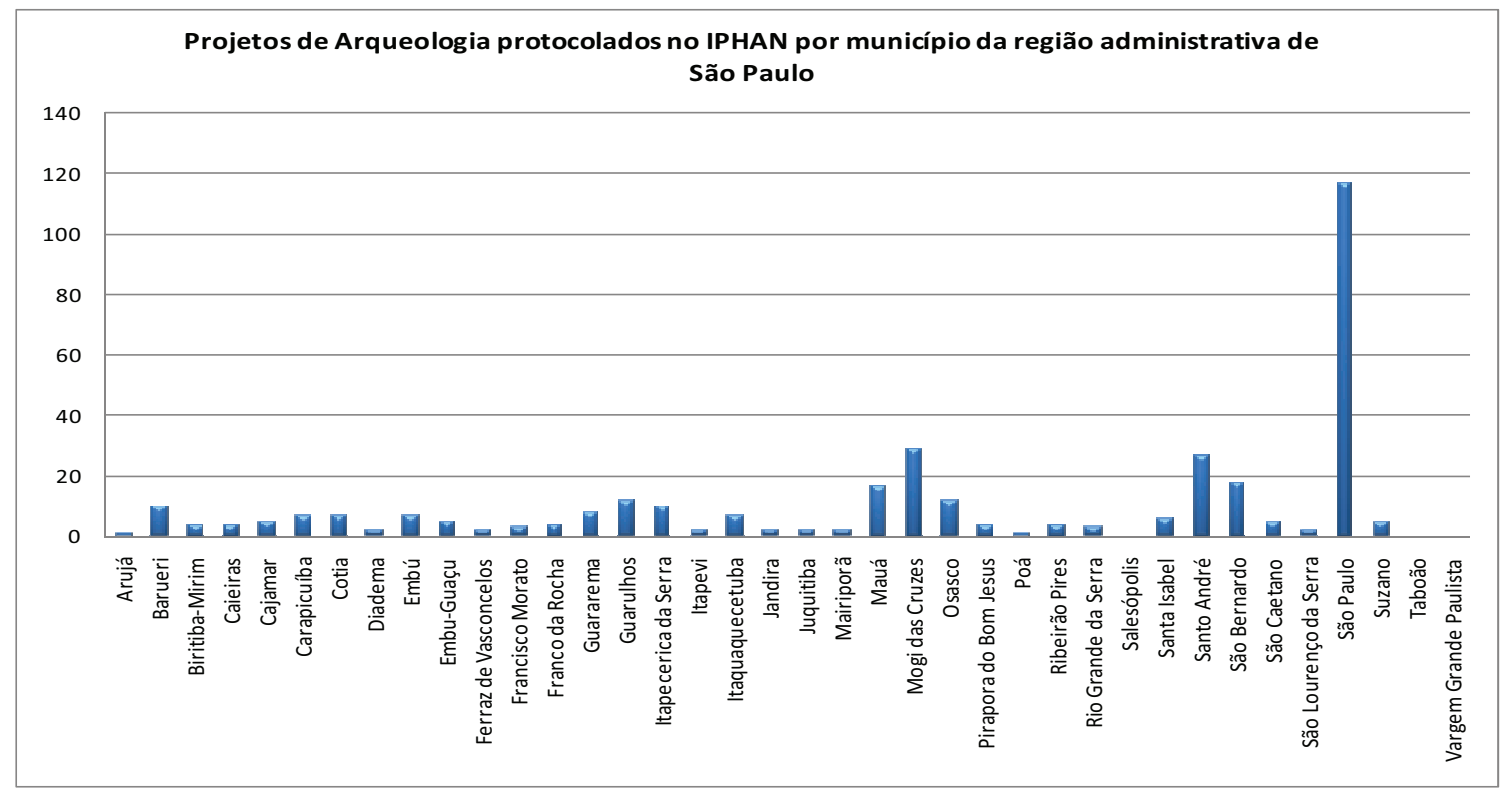

Os projetos levados a cabo até abril de 2009 resultaram no cadastramento de 94 sítios para a região metropolitana, o que significa uma média aproximada de 2,4 sítios por cidade. Estes poucos sítios arqueológicos, distribuem-se, na região, da seguinte maneira: 


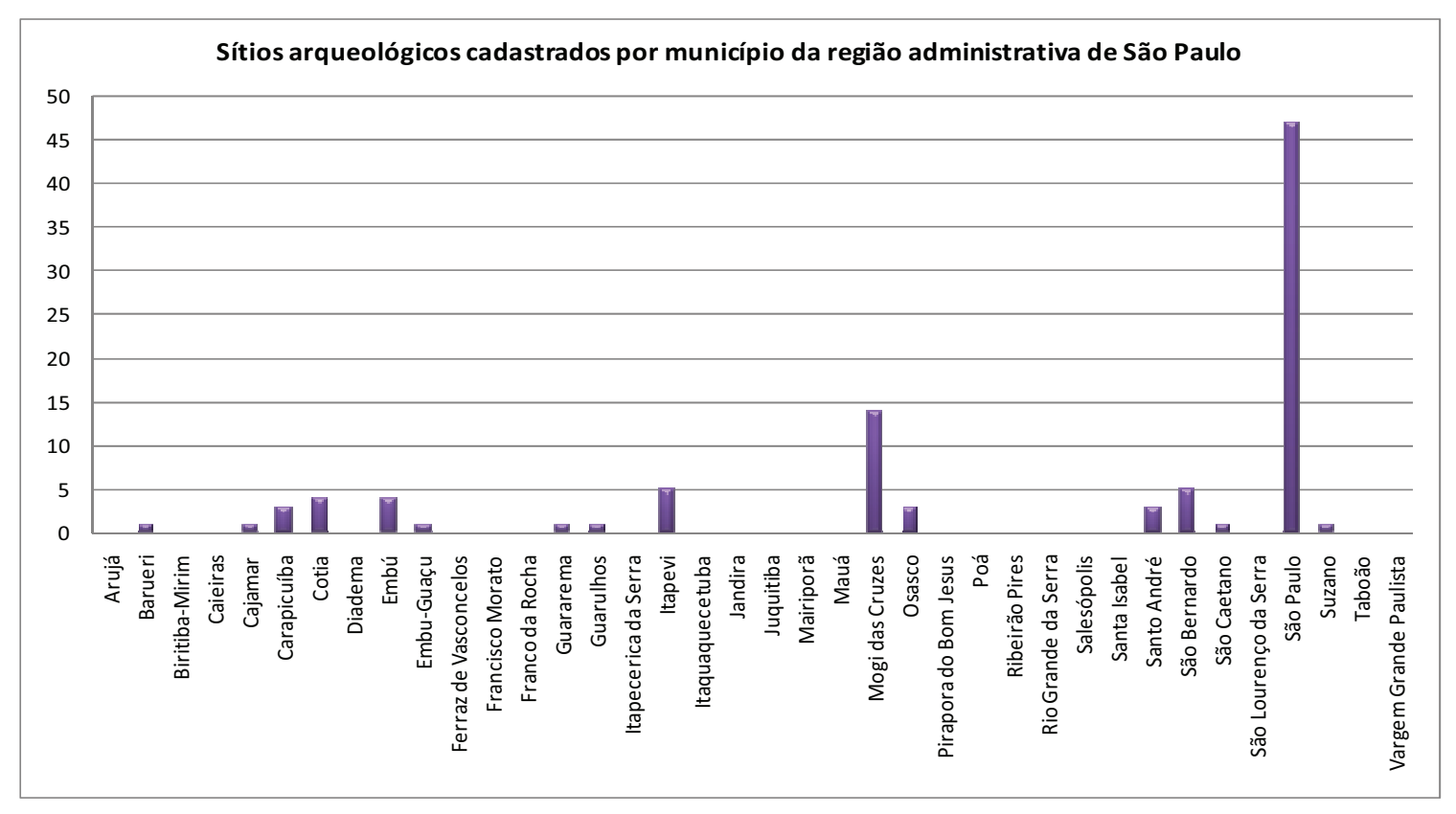

Clara correspondência, portanto, entre a existência de sítios arqueológicos e os municípios onde houve mais projetos de arqueologia, como em Mogi das Cruzes e São Paulo. No entanto, o que se pode perceber, pela análise dos relatórios, é que a relação entre projetos que nada encontram e aqueles que localizaram sítios ou algo de "interesse arqueológico" é muitíssimo baixa, resultando na média aproximada de 0,26 sítios por projeto na região metropolitana e 0,4 sítios por projeto na cidade de São Paulo. O gráfíco abaixo mostra a proporção entre os projetos que resultaram no cadastramento de sítios arqueológicos e os que apresentaram, como parecer, "potencial arqueológico nulo" ou "ausência de interesse arqueológico". 


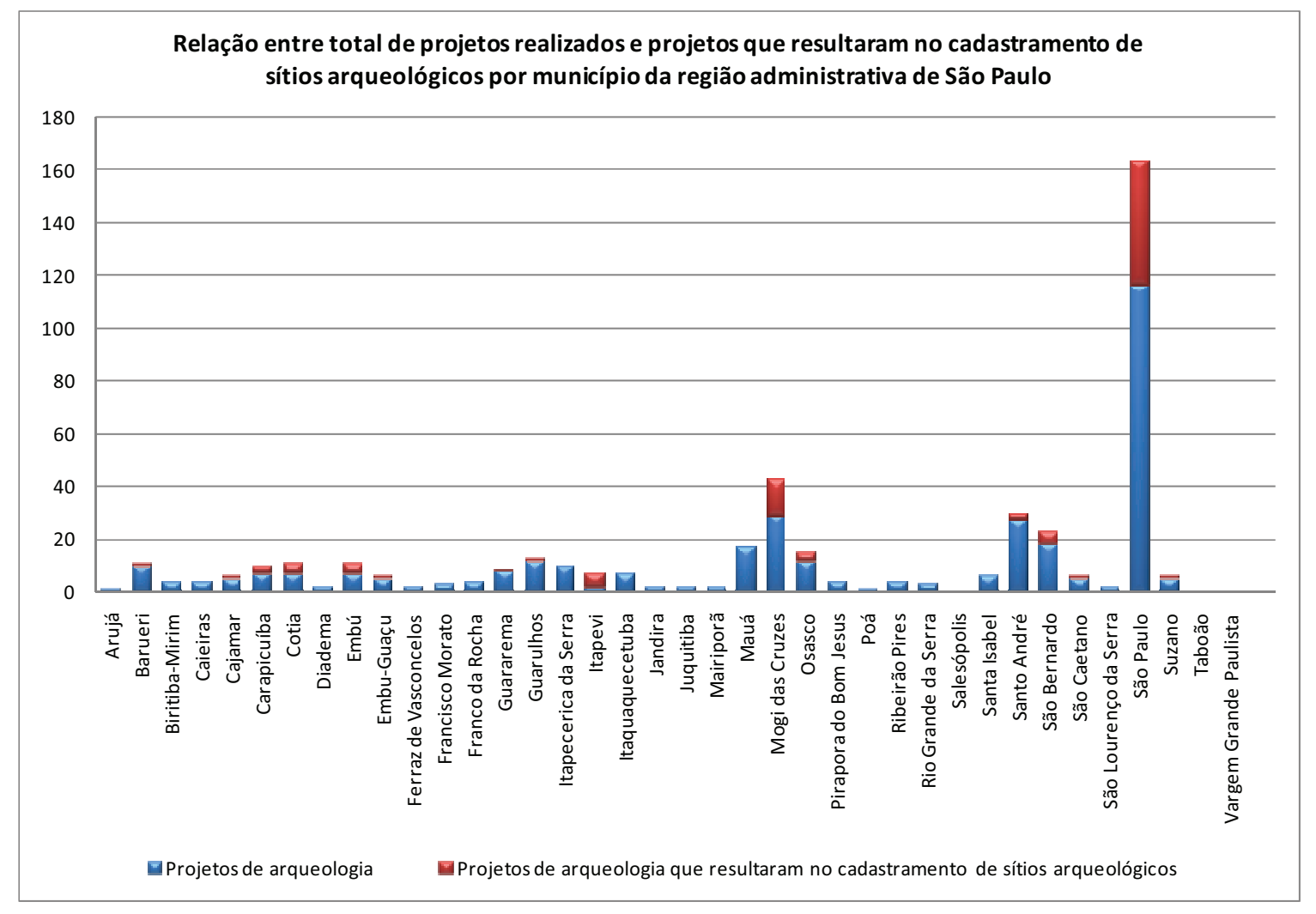

Aqueles projetos que localizaram as chamadas "ocorrências arqueológicas" ou vestígios que, teoricamente, teriam interesse arqueológico, não foram incluídos como projetos que resultaram no achado de sítios arqueológicos, apesar de alguns vestígios localizados serem bastante relevantes, nem por isso gerando aprofundamentos das pesquisas ou programas de prospecção. Alguns relatórios ainda trazem informações sobre as sucessivas e, por vezes, enormes, camadas de aterros na cidade de São Paulo, reflexo da evolução urbana, dos diálogos com a paisagem e da relação homem-natureza, uma vez que aterros são artefatos produzidos pelo homem, portanto relacionados a culturas e visões de mundo. Mas a regra geral é desconsiderá-los do ponto de vista da relevância arqueológica. Como é possível que alguma área da cidade não possua "relevância" arqueológica?

Foi possível inferir, igualmente, pelos cadastramentos, que a grande maioria dos sítios na região metropolitana são históricos - não obstante a ínfima produção acadêmica sobre eles (JULIANI 1996; ZANETTINI 2005; VILAR 2007; CARVALHO 1999). A mesma relação percentual se mantém para a cidade de São Paulo: 

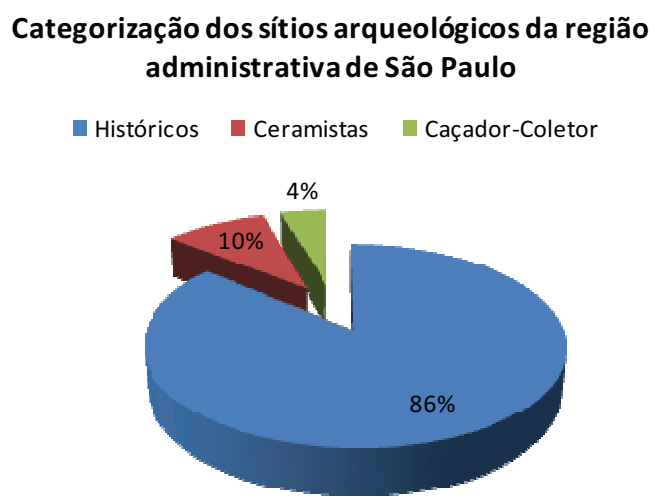

Categorias dos sítios arqueológicos da cidade de São

Paulo

Históricos Ceramistas Caçador-Coletor

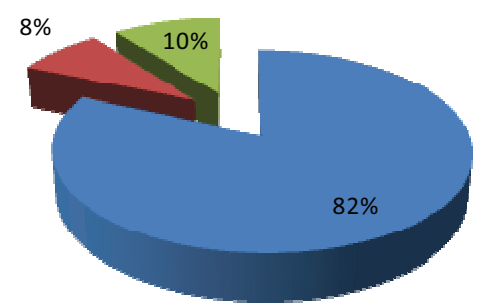

Em linhas gerais, finalmente, o que pode ser notado através da consulta aos projetos de arqueologia presentes no IPHAN-SP é um grande descompasso entre um discurso, que é descrito nos próprios projetos, com definições sobre Arqueologia Histórica e Arqueologia Urbana, acompanhado da justificativa destes projetos e da relevância da arqueologia na cidade, com os resultados das pesquisas ressaltando o potencial arqueológico nulo do meio urbano, ignorando sua complexa estratigrafia, assim como suas edificações e outras modificações urbanas na paisagem, ou mesmo liberando áreas que, teórica e aparentemente, não teriam potencial arqueológico em sub-superfície, sem se quer realizarem intervenções e sondagens. "Se o sítio arqueológico, no caso da arqueologia urbana, é a cidade inteira, cada compartimento desse sítio - rua, quadra, edifício, várzea, fábrica - será um contexto arqueológico, ou seja, cada ente da cidade será um fragmento do sítio arqueológico, o que equipara em termos de relevância os fragmentos enterrados - objetos de atuação por excelência da arqueologia - e as informações fornecidas pela paisagem, pela bibliografia e pela iconografia" (BAVA DE CAMARGO 2009).

Se a cidade é o "sítio", não pode haver intervenções dentro deste "sítio" que não resultem em indícios arqueológicos; não faz sentido negar um caráter arqueológico na/da cidade afirmando-se que ela é antrópica... Termos como "antropizados" ou "antrópicos" não poderiam ser usadas para justificar a ausência de artefatos arqueológicos, uma vez que sua utilização gera uma incongruência conceitual, já que "antrópico" e "arqueológico" não são opostos ou mutuamente excludentes, se a Arqueologia se define, precisamente, como o

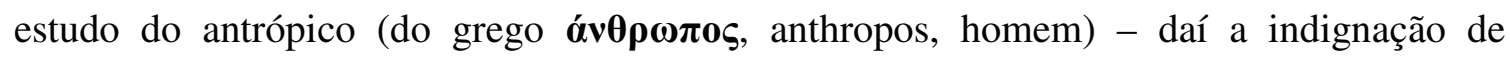
arqueólogos quando existe um senso comum que os associa aos dinossauros. Se é possível 
que o subsolo da cidade não seja, intrinsecamente, arqueológico em sua essência, também não se poderia desconsiderar a possibilidade de localizar sítios como o Petybon (São Paulo), Instituto Bom Pastor (São Paulo), Linhão (São Bernardo), Chácara Cayres (São Bernardo), Fundação (São Caetano), Morumbi (São Paulo), Casa do Itaim (São Paulo) e muitos outros.

Com isto não digo que aterros devem ser cadastrados como sítios arqueológicos, mas que deve ser efetuada uma leitura arqueológica do meio urbano e que monitoramentos de gasodutos no meio de avenidas podem gerar conhecimento arqueológico sobre a evolução urbana da cidade. Falta, para Bava de Camargo (ZANETTINI ARQUEOLOGIA 2009), nestas abordagens, pensar o processo de urbanização paulistana através da arqueologia, efetuando uma arqueologia para a cidade de São Paulo. Pensando esta Arqueologia Urbana, sistematizei algumas idéias na dissertação, sempre pautando-me nas perguntas feitas para e pelo sítio arqueológico, distribuídas ao longo dos capítulos 2, 3 e 4.

O capítulo 2 teve como objetivo apresentar as análises e os artefatos do sítio Petybon. Como o sítio é uma unidade fabril de cerâmica branca, alguns dos objetos e alguns dos atributos que elenquei são desconhecidos. Por isso, na medida do possível, procurei explicar as categorias e o que são, para que servem e o que significam, em especial em relação àqueles artefatos que compõem o "mobiliário do forno" utilizado para a fabricação das faianças finas em uma cadeia produtiva de caráter taylorista.

A partir de algumas problemáticas levantadas pela análise da cultura material, organizei a dissertação agrupando as questões concernentes a um "fora da Fábrica" e um "dentro da Fábrica", isto é, em aspectos da produção e aspectos do consumo passíveis de serem pensados pela interpretação do material arqueológico. Com isto não quero dizer que produção e consumo sejam, de modo algum, esferas separadas; as utilizei para fins didáticos. Cada universo foi dividido em sub-capítulos, com temáticas específicas, mas que se coadunam. Optei por realizar os sub-capítulos na forma de ensaios, bebendo um pouco da ânsia de flexibilidade e novas possibilidades interpretativas que o gênero do "ensaio" ganhou com Burckhardt (1991: 19).

O capítulo 3 refere-se a questões pensadas no "lado de dentro da Fábrica", na esfera da produção, com a história de seu desenvolvimento, seus funcionários, sua cadeia operatória, os defeitos gerados durante este processo, e seus consumos, a relação das louças 
com as teses higienistas na cidade, a presença das impressões digitais, o diálogo com a presença do trabalhador na produção e a análise dos artefatos com inscrição a lápis que foram localizados durante as escavações.

Já o capítulo 4 aponta questões da esfera do consumo e do consumidor das louças em faiança finas nacionais, com reflexões sobre formas e volumes, técnicas e motivos decorativos, além de uma imersão no universo das louças nas publicidades de periódicos e nos inventários da grande São Paulo durante os anos 1910 e 1930.

Por fim, as considerações finais estão no capítulo 5, no qual procurei mostrar como algumas idéias e projetos de modernidade para São Paulo determinaram aspectos de leituras da cidade que influenciaram até mesmo as categorias de análise que elenquei para as louças, pautando-me nas críticas que a teoria pós-colonial faz de certas abordagens. Assim, aponto também à carga ideológica e política que marca a Arqueologia, e que levou à construções de noções de "cópia" ou de "sala de espera da modernidade" por toda a América Latina, tentando, talvez, aproximar-me, um pouco, daquilo que Gramsci (2000) uma vez propôs como "intelectual orgânico" ou Said como "intelectual secular" ou "exilado". Este não é um capítulo sobre teoria arqueológica, pois busquei por toda a dissertação não apartar a teoria da cultura material, da materialidade de seus fundamentos (CONSENS 2004: 143).

É claro que nada do que foi dito acima seria possível sem a escavação do sítio Petybon no ano de 2003 e o esforço do arqueólogo Paulo Zanettini e equipe, composta, à época, por Camila Moraes Azevedo Vichiers, Ana Cristina Jutgla, Daniella Magri Amaral, João Henrique Rosa, Leandro Domingues Duran, Luiz Fernando Erig Lima, Paulo José de Lima, Gabriela Farias, Leandro Key Higuchi Yanaze, (através do trabalho de contrato efetuado pela Zanettini Arqueologia), não apenas para escavar, como também para “convencer”. Da mesma maneira, sem a presença do Departamento de Patrimônio Histórico (DPH) nem mesmo uma vistoria teria sido feita no local.

No âmbito acadêmico, não teria sido possível pensar o Petybon sem o apoio da Prof $^{\mathrm{a}}$. Dr ${ }^{\mathrm{a}}$. Margarida Andreatta e sem o auxílio financeiro prestado pelo CNPq através de uma bolsa de mestrado. Ao início, no entanto, desta pesquisa no âmbito da universidade, devo agradecer ao Prof. Dr. Pedro Paulo Funari, pela longa orientação durante toda a graduação. Ao Museu de Arqueologia e Etnologia da USP pelo suporte dos laboratórios e 
pela salvaguarda de parte da coleção gerada pelo sítio Petybon, um "elefante branco" que poucas instituições quiseram como acervo.

Muitas foram as pessoas que auxiliaram, de algum modo, nesta pesquisa. Agradeço, primeiramente, aos trabalhadores da Fabrica de Porcelana Monte Sião, sem os quais, e sem a qual, não teria compreendido nem um décimo do processo produtivo e do cotidiano fabril da Fábrica Santa Catharina e IRFM - São Paulo. À Renata Xavier Amaral, Jaqueline Lourenço, Fábio Carvalho, Flávia Azevedo, Lettícia Leite, Sérgio Francisco, Grasiela Toledo, Silvana Zuse, Louise Alfonso, Márcia Lika Hattori, Camila Moraes Vichiers, Michelle Tizuka, à Prof. Dr. Fabíola Silva pelas sugestões durante o exame de qualificação, Flávia Godoy, Simone Domingos, à Prof. Dr. Lourdes Domingues, Luana Antonetto, Juliana Luz, Roberta Calábria Albertim, à equipe do setor de arqueologia da $9^{\mathrm{a}}$ Subregional do IPHAN em São Paulo, sem a qual não haveria acesso à coleção IPHAN, ao Prof. Dr. Luiz Cláudio Symanski e ao Prof. Dr. Paulo Zanettini. Ao Prof. Dr. Carlos Appoloni e a Prof. Gelvam Hartmann. Por fim, a D. Eduardo Fagundes, descendente da família Fagundes, os primeiros proprietários da Fábrica, e a Sra. Ignez Cavalheiro, moradora que conviveu com a Fábrica, pelas conversas que me auxiliaram, em muito, a conhecer o mundo dos produtores, por um lado, e dos consumidores, por outro. A meus pais, Ângela e Elias, por todo o suporte à dissertação, e a Carol e Natália. 


\section{CAPÍTULO 1}

\section{PROGRAMA DE PROSPECÇÕES E RESGATE ARQUEOLÓGICO DO SÍTIO PETYBON - ESCAVANDO UMA UNIDADE FABRIL E UM ATERRO DE CERÂMICA NA CIDADE}

Landfills are important to archaeologist because we learn about past societies by excavating buried discards (...) ... landfills are, as archaeologists who excavate older dumps must suspect, millions of small lenses from millions of diverse deposition episodes (...) Landfills digs have recorded traditional types of archaeological data on changing life ways... (RATHJE, HUGHES, WILSON, TANI, ARHCER, HUNT \& JONES 1992: 444)

As cidades trazem em si camadas superpostas de resíduos materiais (...) Poucas vezes mantidos em sua integridade, sobrevivem na forma de fragmentos, resíduos de outros tempos, suportes materiais da memória, marcas do passado inscritas no presente. (BRESCIANI 1999: 11)

\section{SUB-CAPÍTULO 1.1 \\ PROGRAMA DE PROSPECÇÕES E RESGATE DO SÍTIO ARQUEOLÓGICO PETYBON}

No ano de 2003, uma vistoria de técnicos do DPH/PMSP a um terreno na Vila Romana, bairro da Lapa, zona metropolitana da cidade de São Paulo, localizou fragmentos de louças que, segundo relatos dos moradores, estariam associados a uma antiga fábrica existente no local. Um documento foi gerado ("Potencial arqueológico da Fábrica de Louças Santa Catharina. Documentação do sítio Petybon”) pela arqueóloga Lúcia de Jesus Cardoso Oliveira Juliani dando parecer favorável à presença de vestígios móveis (louças), com integridade entre 25-75\%, levando ao cadastramento do local como sítio arqueológico. Passou a ser conhecido no CNSA/IPHAN como sítio Petybon, denominação que remete à última fase de atividades desempenhada na unidade fabril outrora existente (Fábrica de Biscoitos Petybon). O documento previa a necessidade de se promover prospecções arqueológicas no terreno, anteriormente à implantação de um empreendimento imobiliário no local, o condomínio Paradiso Vila Romana. 
À época, a avaliação deu-se a partir da análise de áreas adjacentes ao terreno que seria submetido a um programa de prospecções ${ }^{3}$, assim como através de inferências tomadas dos registros textuais e iconográficos identificados pelo DPH/PMSP. Nesta vistoria não foram efetuadas intervenções arqueológicas propriamente ditas, no subsolo da propriedade, e a qualificação de seu potencial exigiu, desta maneira, a conformação de um programa de prospecções com abordagem abrangente e sistemática, no sentido de avaliar as proposições do DPH e, em caso positivo, contextualizar e exumar os vestígios remanescentes.

Foi assim que, em agosto do mesmo ano, a empresa Zanettini Arqueologia foi contratada para dar início a um programa de prospecções e resgate no sítio Petybon, sob autorização federal de pesquisa IPHAN/MinC Portaria ${ }^{\circ} 151$ de $1^{\circ}$ de Agosto de 2003, em terreno então pertencente à Companhia Mofarrej de Empreendimentos, contando com aproximadamente 13,5 mil m², sob coordenação do arqueólogo Paulo Eduardo Zanettini. O terreno atualmente localiza-se entre as ruas Fábia, Coriolano e Aurélia, na Vila Romana, bairro da Lapa (coordenada UTM 23 K 0326574 / 7397261). A área incide sobre parcela de terreno originalmente pertencente ao complexo industrial de Louças Santa Catharina, a qual sofreu paulatinas transformações em seu layout, de modo a atender a novas finalidades (no caso, a produção de gêneros alimentícios), até sua completa desativação no final dos anos 1980.

As atividades do programa arqueológico sistematizaram fontes textuais, cartográficas, iconográficas e testemunhos orais que permitiram estabelecer o processo ocupacional e as transformações vivenciadas pela área desde a implantação da fábrica de louças em 1913. Foram organizadas em duas fases: uma primeira, que abarcou prospecções geofísicas não invasivas com a utilização do Radar de Penetração no Solo (GPR), levada a cabo em julho de 2003, e uma segunda, que concerniu nas escavações arqueológicas propriamente ditas, envolvendo intervenções em sub-superfície, realizadas em agosto do mesmo ano.

As prospecções com o GPR abrangeram 36\% do terreno submetido a estudos, ou seja, $3.500 \mathrm{~m}^{2}$; para a área definida como de maior potencial arqueológico, foi utilizada uma antena de $100 \mathrm{Mhz}$, de maior penetração, totalizando $1.842 \mathrm{~m}^{2}$ de recobertura. A efetuação de prospecções geofísicas através do GPR propiciou a definição de áreas dotadas de maior potencial arqueológico para posteriores escavações; por outro lado, o Radar auxiliou a equipe

\footnotetext{
${ }^{3} \mathrm{Na}$ época, o terreno submetido aos estudos possuía aproximadamente 13,5 mil $\mathrm{m}^{2}$, enquanto a área da antiga Fábrica que ali existia ocupava terreno com cerca de $36 \mathrm{mil} \mathrm{m}^{2}$. O restante do terreno original, hoje, é cortado por duas ruas e possui algumas casas. Por isso se as pessoas cavarem seus quintais irão encontrar, sem sombra de dúvida, muitas louças.
} 
de arqueologia na tomada de decisões dos locais que não deveriam, de modo algum, ser submetidos à perfurações, e dos que se caracterizaram como zonas intensivamente perturbadas, reduzindo-se custos e danos desnecessários a equipamentos públicos ainda em uso, como redes de água e esgoto (ZANETTINI ARQUEOLOGIA 2003).

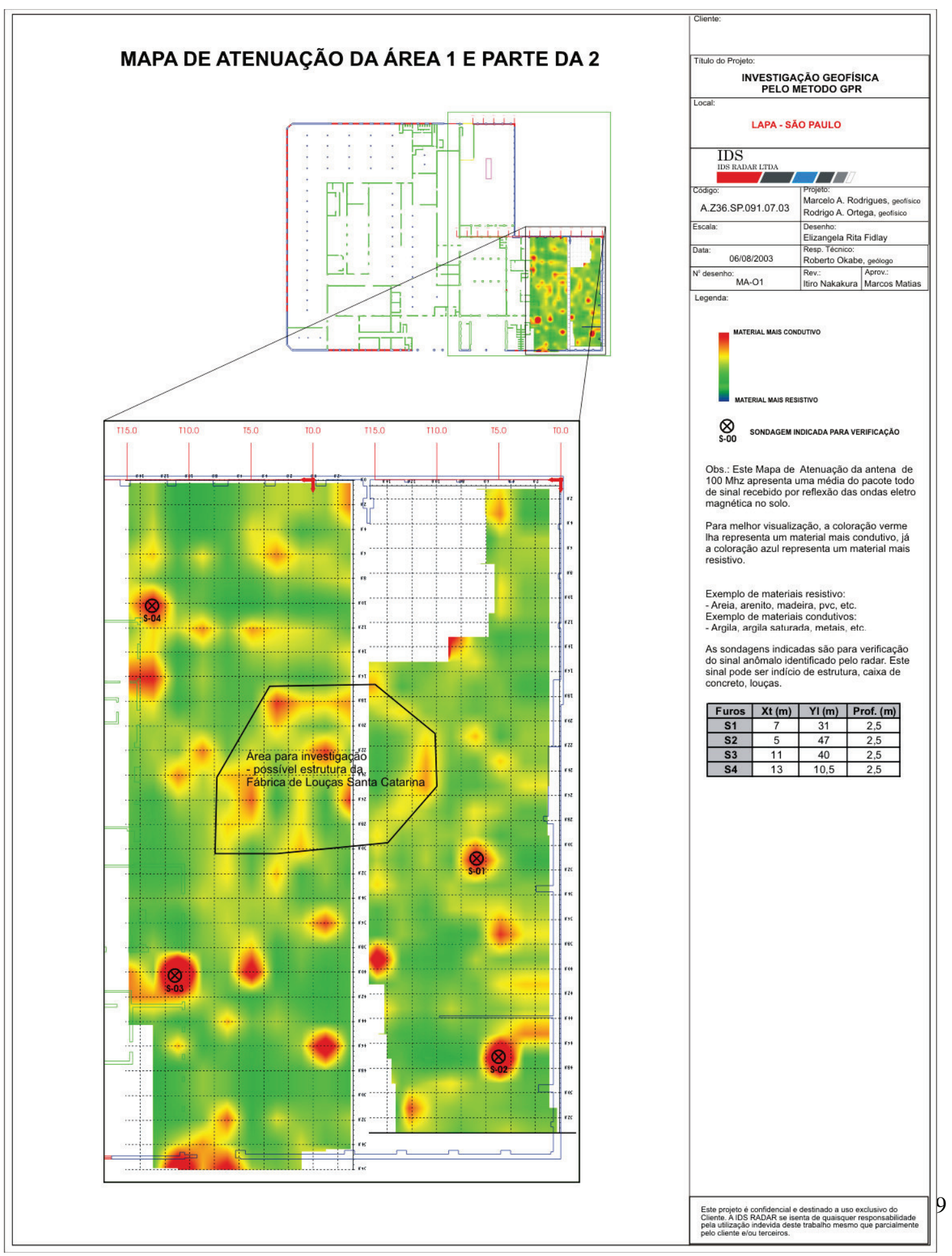




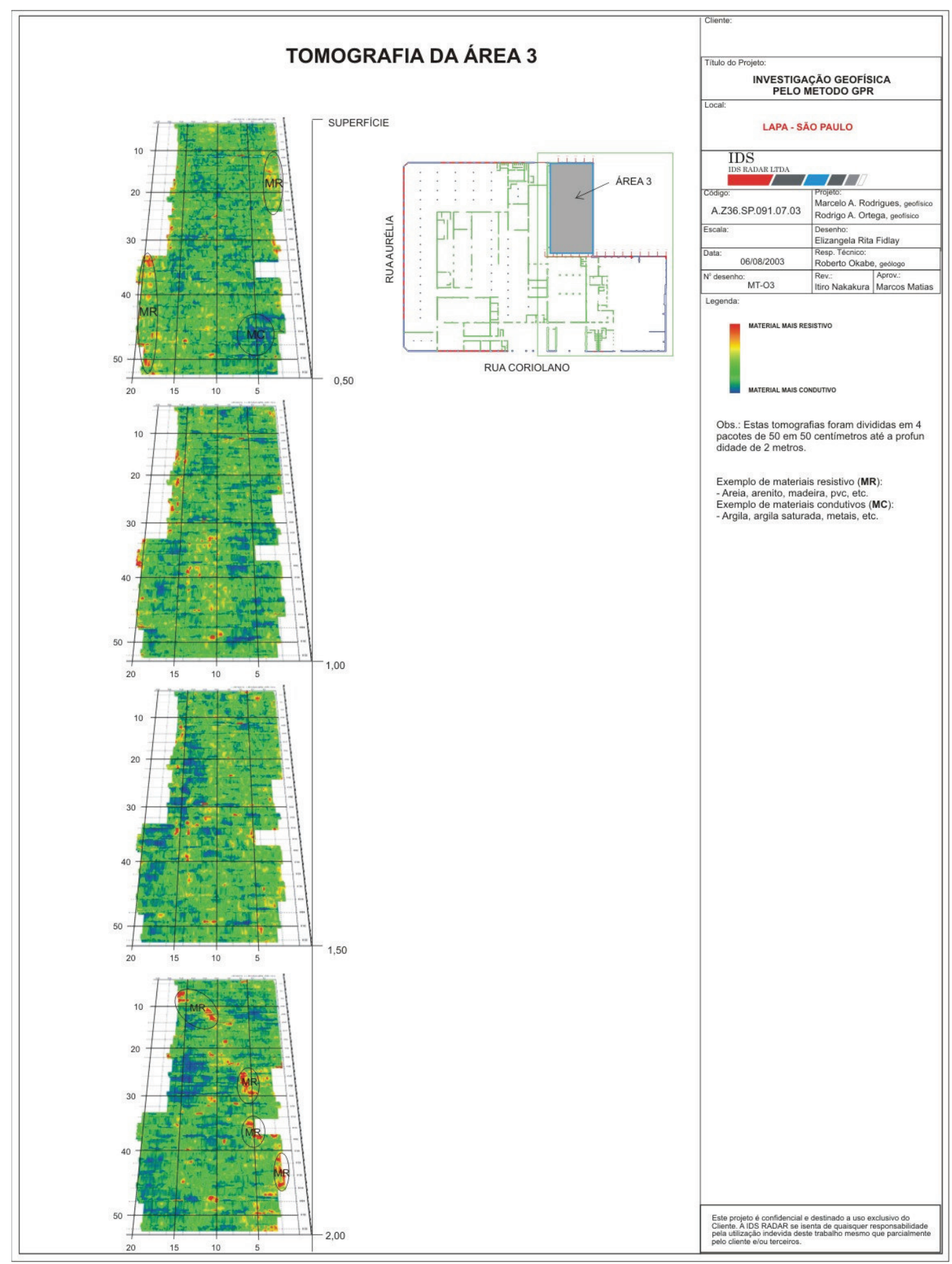

De posse de alguns dados históricos, da análise cartográfica, e do estudo geofísico, passou-se à etapa de escavação. Foram abertas, manualmente ou com auxílio de maquinário, um total de 39 unidades de escavação (denominação dada a todas as intervenções sub- 
superfície, independente de seus formatos e tamanhos), que variaram de sondagens métricas (1 x $1 \mathrm{~m}$ ) a escavações controladas de 4 a $30 \mathrm{~m}^{2}$ (ZANETTINI ARQUEOLOGIA 2003).

As primeiras intervenções objetivaram a qualificação dos estratos arqueológicos e a seleção de áreas dotadas de vestígios a serem submetidas a escavações de detalhe, gerando um primeiro zoneamento do sítio Petybon. Deste modo, três grandes zonas de interesse e potencial (especialmente para vestígios móveis) foram definidas, a saber:

1) Zona de baixo potencial arqueológico

2) Zona de médio potencial arqueológico

3) Zona de alto potencial arqueológico

A Zona de baixo potencial arqueológico (UE 5 a 28) foi aquela voltada para as ruas Aurélia, Coriolano e Fábia, a leste do terreno, conformando um pequeno platô elevado, cuja cota, na época, era levemente inferior ao nível da rua Coriolano. Segundo as plantas históricas, esta era a área ocupada pelas edificações que compunham a Fábrica Santa Catharina e mais tarde a Petybon, às quais sofreram diversas reformas e demolições ao longo dos anos. Por isso, a área apresentou baixa densidade de artefatos, com predominância de elementos estruturais como vigas, baldrames, seções de canaletas, tubulações de água e caixas de concreto.

A Zona de médio potencial arqueológico (UE 1, 2, 30 e 31), na porção oeste do terreno era, segundo a cartografia, parcialmente ocupada por edificações, servindo também de pátio aberto para carga e descarga, descarte de material, etc., o que acarretou seqüencias bem delineadas de camadas de aterramento aplicadas para proporcionar a elevação da cota original e a impermeabilização do local, uma vez que por ali passava um córrego que cortava a propriedade. Esta drenagem foi canalizada anteriormente à década de 1930 (ZANETTINI ARQUEOLOGIA 2003), e a galeria dela originada estava alinhada com os atuais traçados das ruas Marco Aurélio e Cipião - segundo análise obtida pelo GPR, todas as tubulações antigas de águas pluviais do complexo corriam para esta galeria.

Nesta zona, foram abertas grandes unidades de escavação lineares, com orientação Norte/Sul, com objetivo de fornecer uma visão mais ampla do comportamento estratigráfico do terreno e das sucessivas intervenções promovidas desde o início do século XX até os anos 1980. As escavações mostraram que a Fábrica Santa Catharina conduzia suas águas por meio de canaletas de tijolos em forma de arco, rumo à drenagem, tendo sido ampliada e remodelada com alvenaria de concreto pela fábrica de biscoitos. Boa parte das escavações 
desta zona atingiu rapidamente o nível freático, situado à $0,70 \mathrm{~m}$ de profundidade, acarretando interrupção das intervenções (especialmente pela qualidade da água aflorante, contaminada em virtude de um rompimento de ramal de esgoto) (ZANETTINI ARQUEOLOGIA 2003). Tais aspectos (a presença do córrego e do lenço freático bastante superficial) caracterizaram o terreno como um ambiente relativamente úmido, submetido a constantes enchentes, e encharcamentos, o que nos leva a entender, por vezes, a presença dos aterros e do uso da cerâmica como elemento drenante. Voltarei a isto mais a seguir.

Por fim, o que foi delimitado como Zona de alto potencial arqueológico (UE 3, 4, 32) estava circunscrito a uma pequena porção a oeste da propriedade, e parece ter sofrido menos interferências em relação às demais zonas, apresentando depósitos de material cerâmico lacrado, bem como alguns vestígios de edificações remanescentes da fase inicial de ocupação do terreno. Apesar disso, não faltam intervenções posteriores como passagens de tubulações, fossas, etc. Também se observou a presença de camadas de aterro, compostas, no entanto, por terra argilosa escura, rica em cinzas e carvões, associadas a louças e azulejos, indicando uma provável proximidade a um dos fornos outrora existentes (ZANETTINI ARQUEOLOGIA 2003). Abaixo desta camada foi localizada uma canaleta construída com tijolos e argamassa de barro que se prestou, no passado, ao lançamento de fluídos ricos em pigmentos (ZANETTINI ARQUEOLOGIA 2003). As escavações na área também foram efetuadas com cautela, uma vez que o subsolo apresentava-se contaminado graças ao rompimento de uma tubulação clandestina de esgoto, o que ocorreu antes do início dos programas arqueológicos. É preciso ressaltar que as camadas de aterro desta zona apresentaram artefatos associados ao processo de produção da fábrica de louças (caixas refratárias, cones pirométricos, mobiliários do forno). 


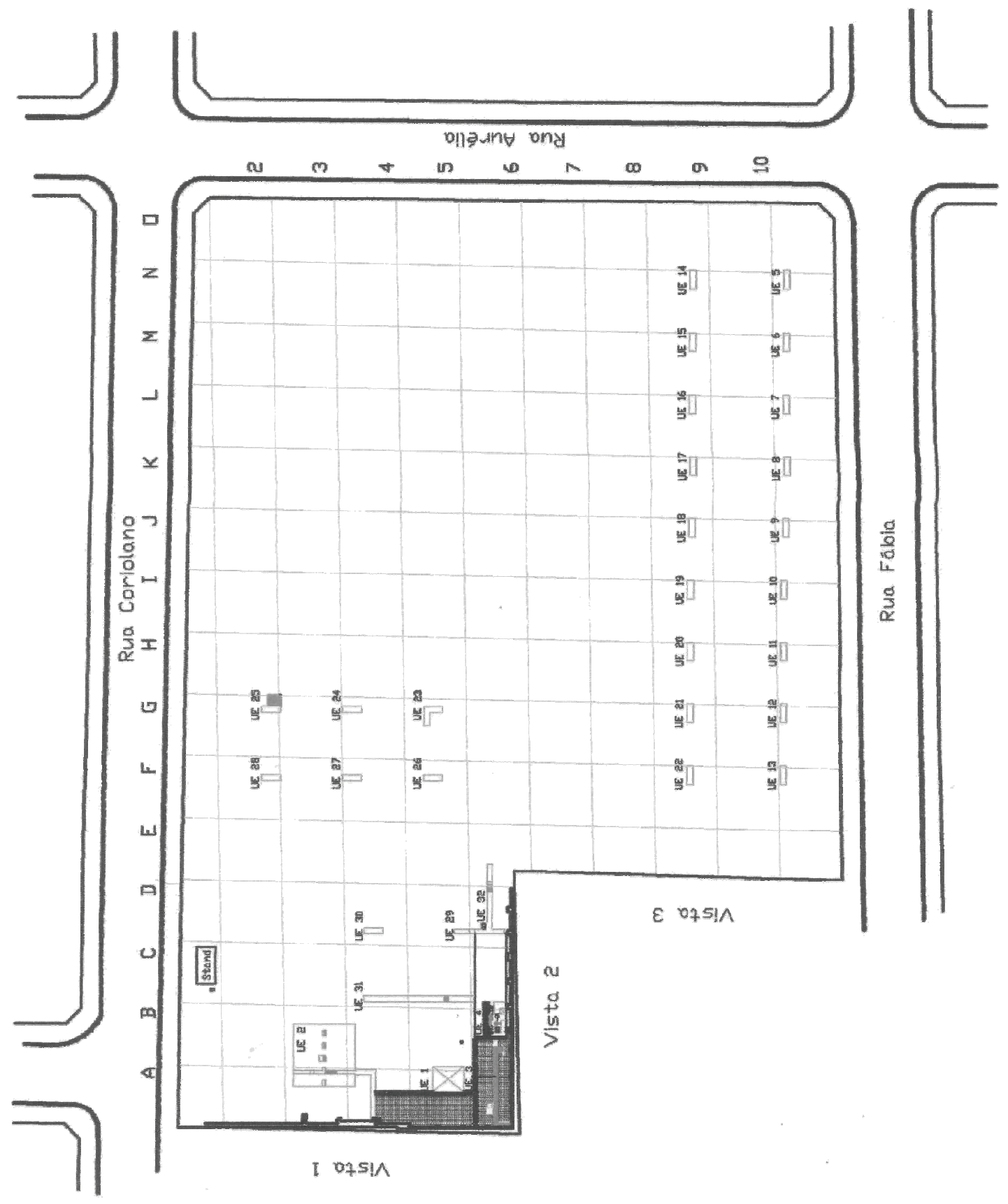

(ZANETTINI ARQUEOLOGIA 2003) 
Abaixo, a planta da escavação sobreposta à aerofotogrametria tirada em 1958, quando a Fábrica já produzia biscoitos (alimentos). Percebe-se que a zona de baixo potencial arqueológico está relacionada à área dos galpões (daí também a localização de muitos alicerces) e a zona de alto potencial arqueológico a região com menos construções (UEs 1, 2, $3,4,29,30,31,32)$. A quantidade de bolsões e aterros com louças aumenta quando nos dirigimos ao quintal da fábrica. Posso apenas imaginar a quantidade, portanto, de louças que está sob o piso das casas na quadra entre as ruas Coriolano, Fábia e Catão, a oeste.

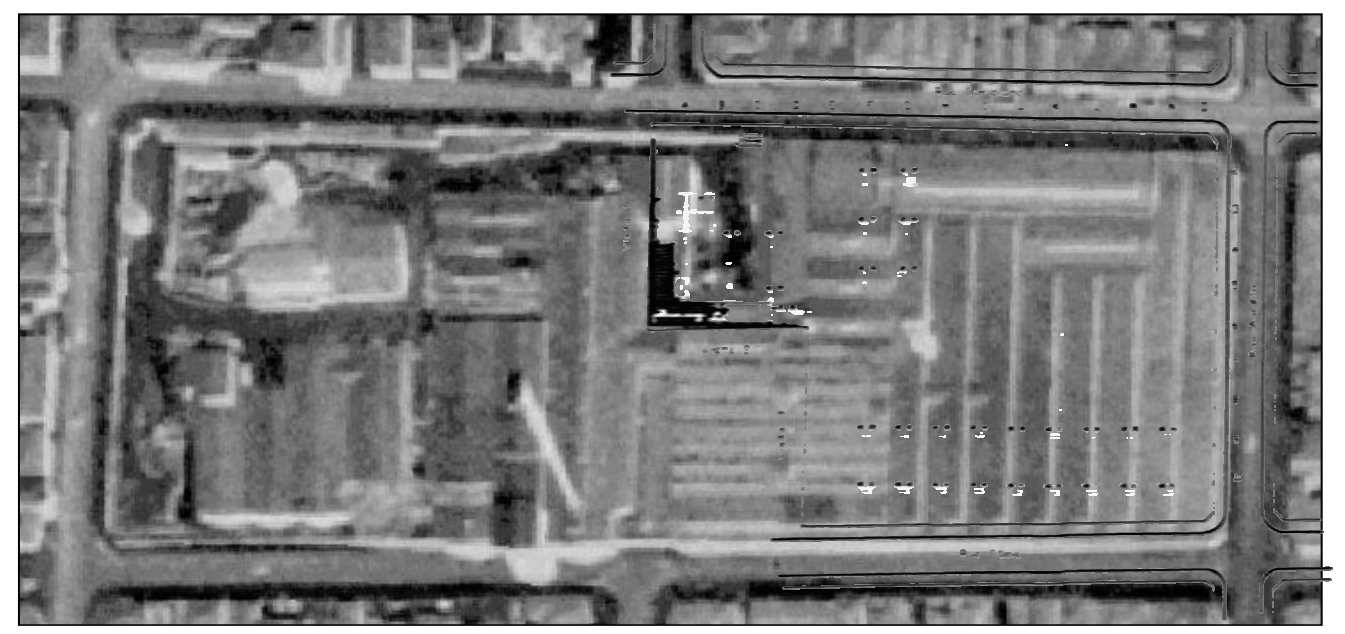




\section{SUB-CAPÍTULO 1.2}

\section{FÁBIA, AURÉLIA, CORIOLANO E CATÃO NA VILA ROMANA: EVOLUÇÃo URBANA E OCUPAÇÃO}

Enquanto trabalho de Arqueologia Urbana, é metodologicamente importante explicitar alguns aspectos da evolução e da ocupação do terreno destinado, inicialmente, à implantação da Fábrica Santa Catharina, em 1913, delimitada pelas ruas Coriolano, Fábia, Aurélia e Catão, na Vila Romana, bairro da Lapa, relevante à compreensão da formação e da história do registro arqueológico. A documentação utilizada, basicamente, pautou-se nas plantas do local, além de alguns documentos oficiais e relatos orais.

As origens da ocupação colonial na Lapa tiveram início nos anos de 1560, quando os jesuítas receberam uma sesmaria próxima ao rio Pinheiros (então chamado Emboaçava ou Boaçava, do tupi "lugar por onde passa"). Ao final do século XVI, a localidade vivia em função do caminho para Santana do Parnaíba, através de sua variante que seguia para Jundiaí e Campinas, bastante usada por grupos tropeiros (SANTOS 1980: 31). Esta ocupação esparsa teria continuado até meados do século XVIII quando os jesuítas estabeleceram uma colônia conhecida como "fazendinha da Lapa", em homenagem a Nossa Senhora do Santuário da Lapa de Lisboa, abandonando o local em 1743 - destarte a permanência do nome. Em 1765, a paragem do Emboaçava contava com cinco casas com 13 homens e 18 mulheres (SEGATTO 1988: 9); novo arrolamento realizado em 1800, pela autoridade eclesiástica da Sé, já apontava para um total de 221 habitantes: 127 mulheres e 94 homens, sendo destes 115 escravos (SANTOS 1980: 32). Do início do século XIX até 1867, foi rota de tropeiros e viajantes que se dirigiam a Itu e ao sertão ou do sertão ao litoral, utilizando-se da ponte do Coronel Anastácio. Este apoio à circulação extra-regional deu-se pela existência, segundo Saint-Hilaire e D'Alicourt, de um pouso de tropas - para Ramos (2001: 59), o mesmo estaria hoje localizado às margens da estrada de Jundiaí e próximo ao córrego onde está o Shopping Bourbon e a Praça Marrey Júnior. A partir de meados do século XIX, vê-se a proliferação de olarias e agricultores em pequenos grupos de trabalhadores, especialmente na área hoje conhecida como Lapa de Baixo, já com a presença de alguns imigrantes.

Em 1867, é inaugurada a estação da Companhia Inglesa; tanto a Lapa quanto a Água Branca constituíam-se, à época, por olarias e sítios (SANTOS 1980: 45). Antes da incorporação do bairro ao que efetivamente se compreendia como núcleo urbano da cidade de 
São Paulo, em meados de 1880, a localidade fornecia produtos primordiais à cidade, via sítios e chácaras, compondo o que ficou conhecido como "cinturão caipira". O bairro da Água Branca foi ligado a Lapa apenas em novembro de 1925, quando a prefeitura recebeu do Dr. Paulo de Souza Queirós as áreas livres entre as ruas Guaicurús, Coriolano, Clélia e Faustolo (SANTOS 1980: 66).

Em 1888 foi iniciado o loteamento da Vila Romana, a primeira iniciativa de ocupação sistemática urbana na Lapa (ZANETTINI ARQUEOLOGIA 2003). O loteamento seguiu um traçado hipodâmico com nomenclaturas de clara inspiração clássica (greco-romana), tão popular nesta virada de século. Em 1891, foi feito o loteamento do Grão Burgo da Lapa, hoje Lapa de Baixo; é nesse período também que ocorreram as instalações das primeiras indústrias e o estabelecimento, em 1899, da estação da São Paulo Railway, que transformou o local em pólo de atração de mão-de-obra, especialmente operária. Quanto ao transporte urbano, os bondes já haviam chegado em 1903, enquanto, além da São Paulo Railway, o bairro contou com a Companhia Sorocabana em 1958, e os primeiros ônibus em 1924 (SEGATTO 1988: $59)$.

Os loteamentos que deram origem a estes bairros foram, de todo modo, intencionais. Desde a crise da abolição e o advento da República, tornara-se prática corrente dos donos de terrenos e chácaras na área urbana lotearem, arruarem ou venderem, para esse fim, suas propriedades (SEVCENKO 1992). Assim foram se adensando bairros já existentes, se formando outros novos e aparecendo núcleos coloniais mais distantes. Pelas várzeas, acompanhando as linhas de trens, se instalavam as indústrias e se formavam os bairros operários (Brás, Pari, Mooca, Ipiranga, Bom Retiro, Barra Funda, Água Branca). Ressalta-se o papel da Light, instalando as paradas finais de suas linhas em pontos extremos pouco povoados, como a Lapa, Santana, Penha, Pinheiros, gerando "fluxos irradiados de valorização imobiliária que, seguindo as direções das linhas, suscitavam a criação de loteamentos em áreas remotas" (SEVCENKO 1992: 123).

É necessário lembrar o estabelecimento não-aleatório de indústrias e fábricas em São Paulo, as quais parecem ter seguido um eixo que compreendia os baixos terraços dos rios Tietê e Tamanduateí, junto às linhas férreas Santos-Jundiaí e Sorocabana (RAMOS 2001: 38). Isto, não apenas pela ferrovia ser o principal meio de transporte da época, mas também pelo fato de que cortavam terrenos planos, amplos, baratos e, teoricamente, impróprios a função residencial. É preciso igualmente ressaltar que a presença das fábricas não extinguiu, de repente, as antigas chácaras, que por cerca de 40 anos co-existiram com as indústrias, 
desaparecendo apenas a partir dos 1930 (RAMOS 2001: 65). Talvez seja por isto que, para o período de estudo deste mestrado, 1913 a 1937, a Lapa fosse um bairro considerado zona rural pela administração municipal, alçando o título de zona suburbana somente nos anos 1940.

Dentre algumas das indústrias que se estabeleceram na Lapa, somadas às antigas olarias, pode-se citar a Vidraria Santa Maria, em 1896, as Oficinas da São Paulo Railway, em 1900, a Fábrica de Tecidos e Bordados Lapa, em 1913, a própria Fábrica de Louças Santa Catharina, em 1913, a Fundição Progresso, em 1916, a Fiat Lux e a Companhia Melhoramentos, em 1919, etc. Muitas das fábricas pertenciam aos Matarazzo. Na região da Água Branca, as IRFM iniciaram o enorme complexo industrial que deu origem ao Parque da Água Branca, que, nos anos 1950, tornou-se o maior complexo industrial da América Latina ${ }^{4}$ (RAMOS 2001: 79). Isto acelerou o crescimento do bairro e fez com que sua população que, em 1920, era de 22 mil habitantes, passasse, em 1950, para 90 mil (SEGATTO 1988: 59).

Somente a partir dos anos 1970 e ao longo da década de 1980 é que houve uma drástica mudança nas feições da Lapa, acarretada pelo início da saída das indústrias para o interior de São Paulo, seguida da derrubada dos galpões, antes ocupados pelas fábricas e suas substituições por edifícios residenciais. Os empreendedores perceberam que a região possuía boa infra-estrutura, centro comercial movimentado, boa rede de transportes, além de saída para as rodovias Anhangüera e Bandeirantes (GARBIN 2003).

Portanto, o delineamento da quadra que corresponde ao sítio Petybon, assim como da quadra que corresponde à antiga Fábrica Santa Catharina, delimitada pelas ruas Aurélia, Coriolano, Fábia e Catão, deu-se neste contexto de loteamento da Vila Romana. No entanto, alguns aspectos de sua formação devem ainda ser esclarecidos. Atualmente, o que se percebe é a existência de três quadras conformadas uma pelas ruas Catão, Coriolano, Fábia e Antonio Califari, outra pelas ruas Henrique Elkis, Aurélia, Coriolano e Fábia (sítio Petybon), e uma menor formada pelas ruas Antônio Califari, Henrique Elkis, Coriolano e Fábia; no entanto, estas três quadras formavam, aparentemente, uma única quadra quando do início do loteamento, totalmente ocupada pela Fábrica Santa Catharina e depois pela Petybon, já que a rua Antônio Califari e a Henrique Elkis não existiam. Ao menos enquanto ruas. As plantas antigas da cidade de São Paulo, nas quais consta o bairro, mostram uma continuação, que corta a quadra sentido Norte/Sul, entre as ruas Cipião e Marco Aurélio, como se ambas

\footnotetext{
${ }^{4}$ Infelizmente, o complexo industrial Matarazzo, do começo do século XX, na Água Branca, foi praticamente destruído, "com o aval da Secretaria de Cultura e Estado, que o considerou apenas como uma listagem de edifícios e de eventuais equipamentos que eles pudessem abrigar" (MENESES 1988: 69).
} 
fossem uma só. Apesar disso, plantas contemporâneas, por vezes, não dividem a quadra em dois, e mostram a presença da Fábrica em apreço ocupando toda a quadra (daí ser paradoxal a existência de uma rua que cortasse o complexo ao meio).

Uma das possibilidades pensadas para o fato é a de que existiria uma passagem pelo terreno, que nunca foi rua, mas que acabou ficando marcada na paisagem e por isso foi desenhada em muitas plantas - por não ser oficial, por vezes não constava. Esta passagem, aparente continuação da rua Cipião para dentro da quadra, sobrepõe-se ao traçado do antigo córrego que cortava a quadra longitudinalmente. A canalização do mesmo foi anterior aos anos 1930 e as pesquisas arqueológicas localizaram sua galeria alinhada às ruas Cipião e Marco Aurélio. Segundo um antigo morador do bairro, o Senhor Antonio Felippe ${ }^{5}$, residente desde 1937, sobre a passagem que se tornou mais tarde a rua Antônio Califari, diz o seguinte:

... Aqui não existia... foi fechado aqui. Isso aqui não era um loteamento, eram terras devolutas, não tinha dono. O Ranzini ficou com tudo isso aqui. A Matarazzo comprou toda essa área do Ranzini. Na divisa entre a Matarazzo e a parte que foi dada como herança para sua filha, há um pequeno rio que fica justamente na ligação das ruas Marco Aurélio e Cipião; você pode ver nas plantas dele, ele não diz que isso aqui é dele. O Mofarrej é que pôs. Eles fecharam isso aqui porque o pessoal atravessava pelo meio da fábrica e, por conveniências, eles fecharam. Aí foi crescendo... (ZANETTINI ARQUEOLOGIA 2003).

Quando da análise das plantas da Vila Romana, percebi uma dinâmica interessante no que concerne à representação do traçado desses arruamentos. Chamo, deste modo, atenção para as diferentes configurações da quadra (ou quadras) na qual estava contida a Fábrica Santa Catharina e que contém o sítio Petybon. Percebi a co-existência de 3 configurações distintas de apresentação da área, cujos layouts são:

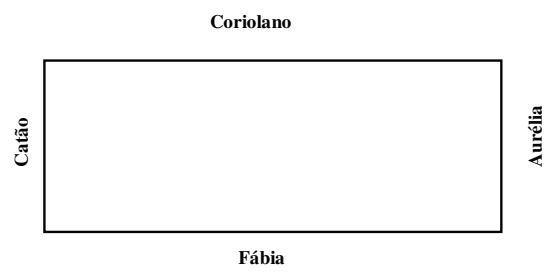

\section{Configuração 1}

Quando a quadra é apresentada inteira, com formato retangular, delimitada pelas ruas Aurélia e Catão (latitudinalmente) e Coriolano e Fábia (longitudinalmente), com seus aproximados $36 \mathrm{mil} \mathrm{m}^{2}$.

\footnotetext{
${ }^{5}$ O Senhor Antonio Felippe, nasceu em 1925, e aos 12 anos foi morar na Lapa, na rua Lituânia, próximo as ruas Tito, Coriolano, Fábia, Aurélia e Catão, com seu pai, o italiano Nicola Felippe, vindos do município de São Manoel, estado de São Paulo. Seu irmão mais novo trabalhou na Fábrica.
} 

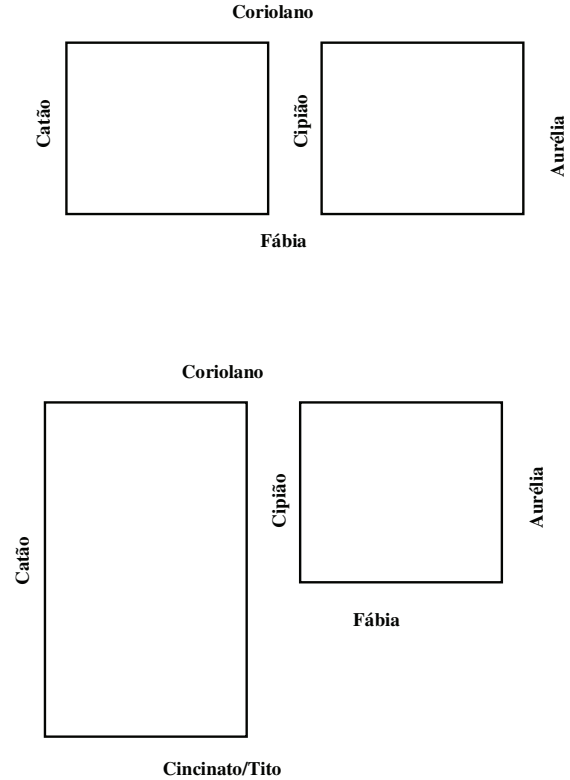

\section{Configuração 2}

Quando a quadra é apresentada dividida em duas, com formatos quadrangular, com uma extensão da rua Cipião (ou Marco Aurélio) cortando o terreno em sentido norte-sul. Assim, formaram-se as quadras delimitadas pelas ruas Catão, pela continuação da Cipião (latitudinalmente), Coriolano e Fábia (longitudinalmente), e pelas ruas continuação da rua Cipião, Aurélia (latitudinalmente), Coriolano e Fábia (longitudinalmente). A quadra da direita é quase a quadra que, em 2003, configurou o sítio Petybon.

\section{Configuração 3}

Quando é apresentada uma quadra quadrangular delimitada pelas ruas Aurélia, Fábia, Coriolano e pela extensão da rua Cipião, e uma quadra retangular, que não apresenta conexão entre as ruas Catão e Fábia, formada pelas ruas Coriolano, Catão, pela extensão da rua Cipião, e pela rua que ora aparece designada como Tito ora Cincinato. A quadra da direita é quase a quadra que, em 2003, configurou o sítio Petybon.

Há que se levar em consideração toda a intencionalidade destas plantas enquanto discursos de poder e que retenções e controle de informações sobre um espaço físico muitas vezes anteciparam a posse desse espaço (PASSOS 2009: 19); as configurações percebidas aqui têm relação com a parcialidade dos mapas que poderiam estar utilizando "artifícios cartográficos" a serviço de algum indivíduo ou grupo (PASSOS 2009: 19).

A seguir, apresento as plantas analisadas (recortadas e acompanhadas por um zoom). Observo que entre as quadras da Vila Romana, o córrego do Mandy se faz sempre presente, a apenas uma ou duas quadras da Fábrica Santa Catharina, mas não há nenhuma representação do córrego que se sobrepõe ao traçado atual das ruas Cipião e Marco Aurélio.
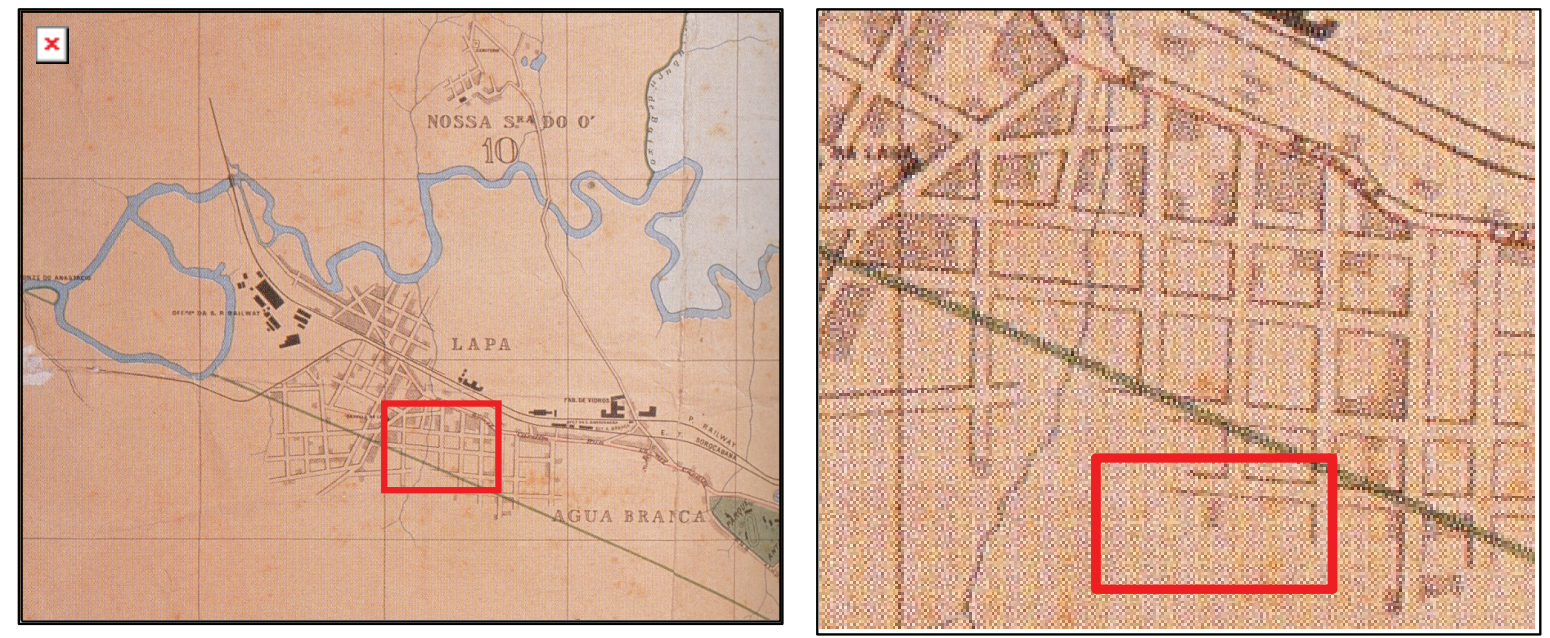

1 - Planta Geral da Cidade de São Paulo - 1905 (PASSOS \& EMIDIO 2009: 48-49) 

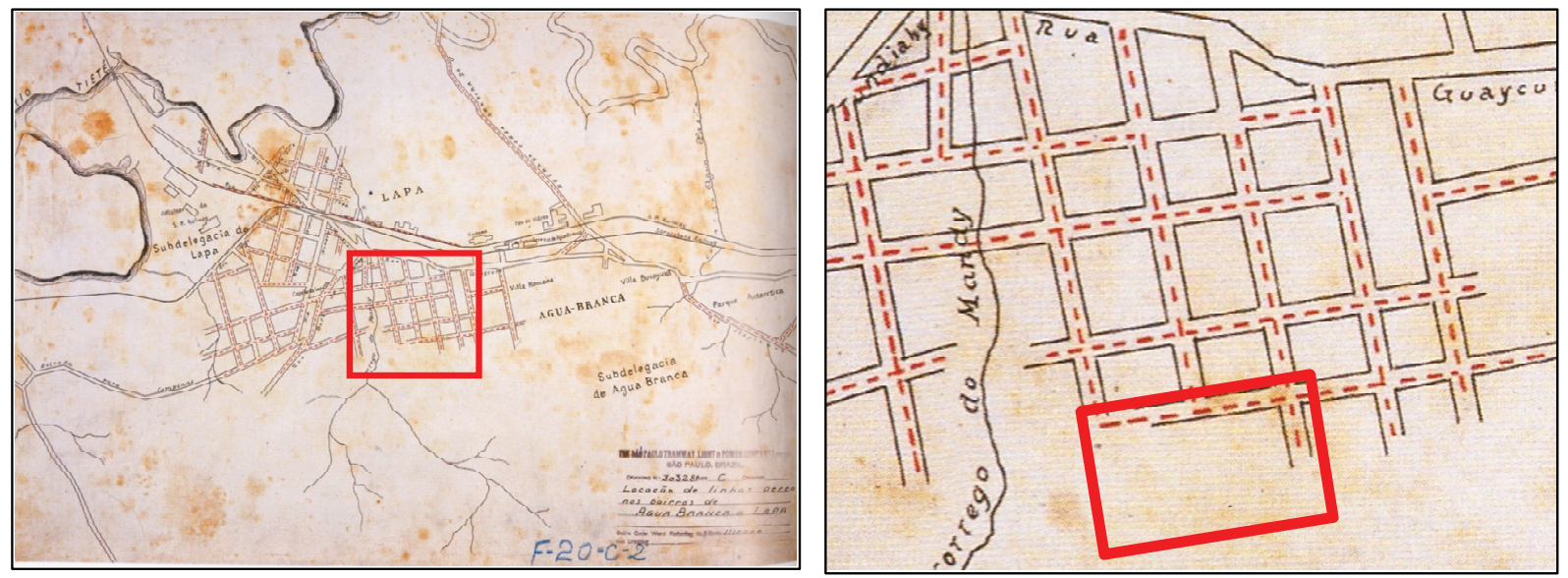

2 - Locação de Linhas Aéreas - sem data (PASSOS \& EMIDIO 2009: 62). Provavelmente feito em torno de 1911
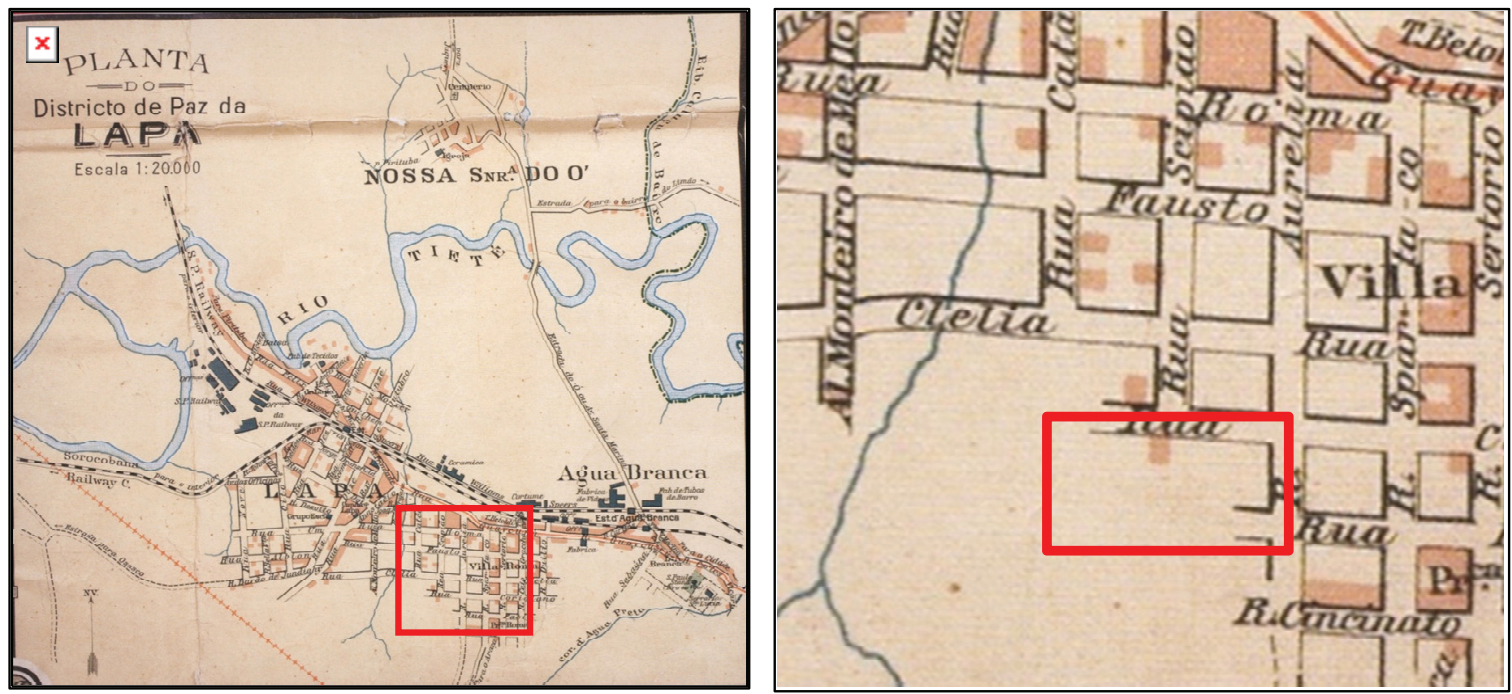

3 - Planta da cidade de São Paulo - 1913 (PASSOS \& EMIDIO 2009: 60-61)
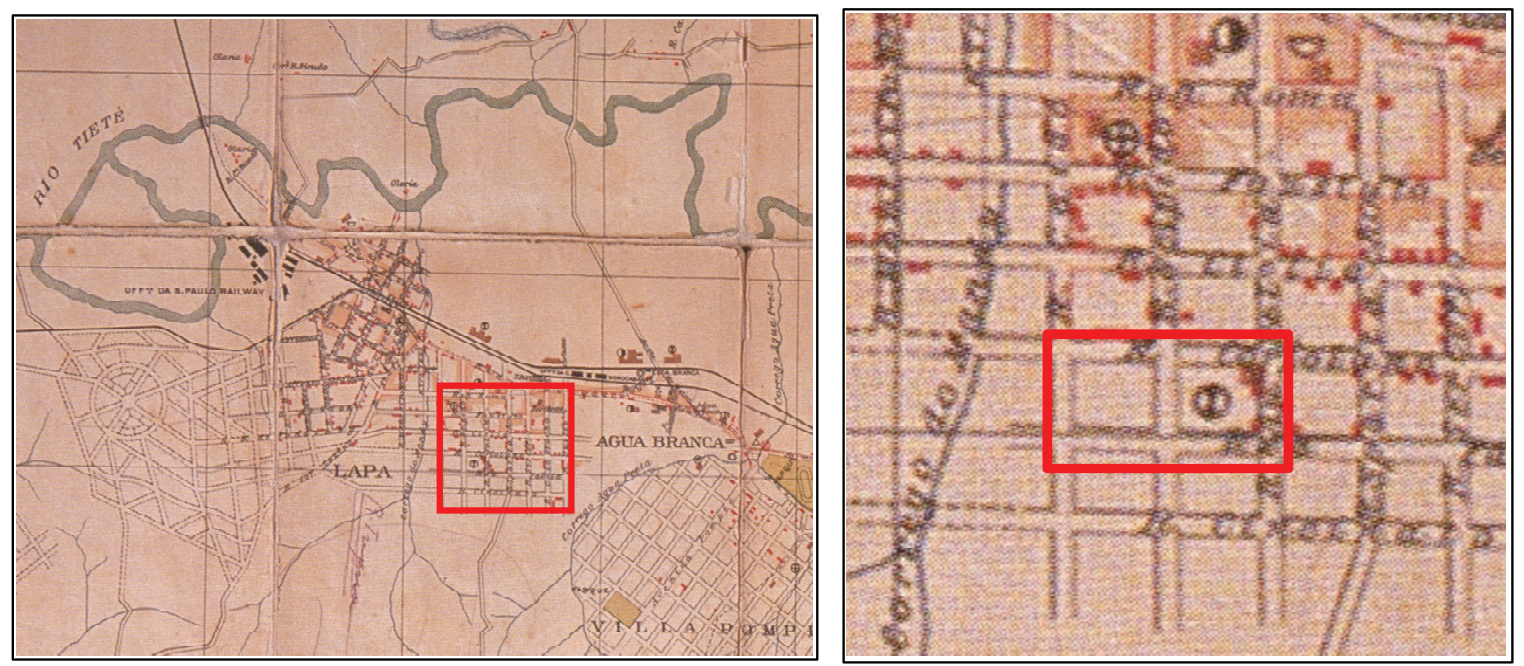

4 - Planta geral da cidade de São Paulo - 1914 (PASSOS \& EMIDIO 2009: 74-75) 

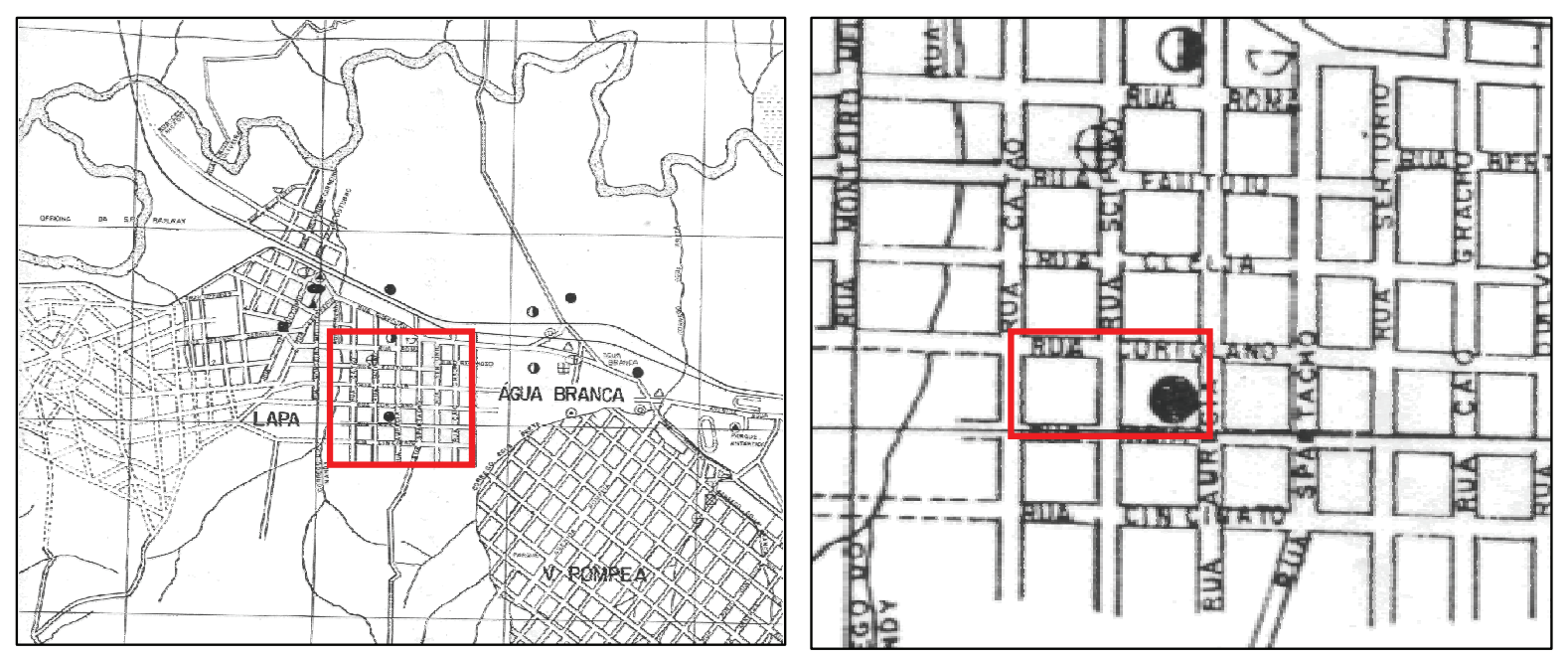

5 - Planta geral da cidade de São Paulo - Comissão Geographica e Geologica - 1914 (Reconstituição da Memória Estatística da Grande São Paulo, 1983)
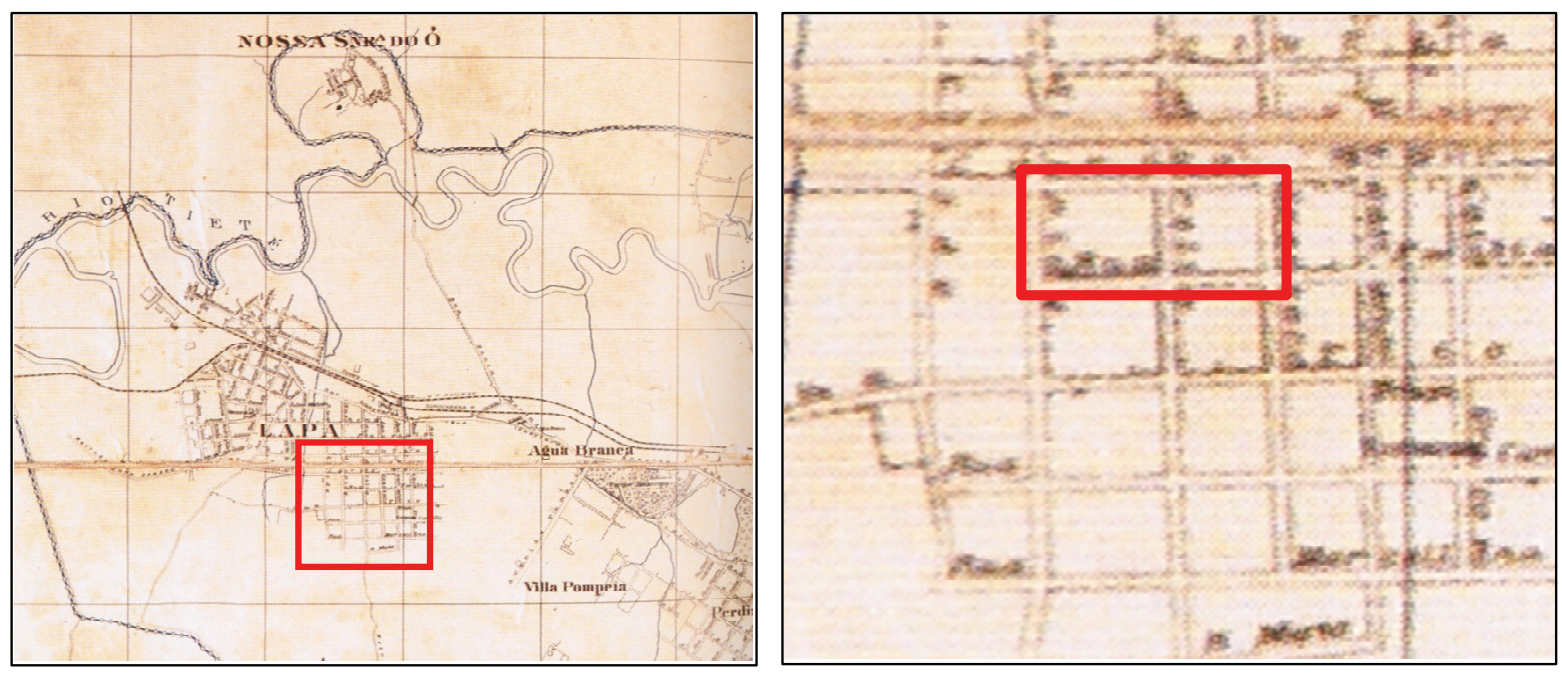

6 - Planta da cidade de São Paulo - 1916 (PASSOS \& EMIDIO 2009: 77-78)
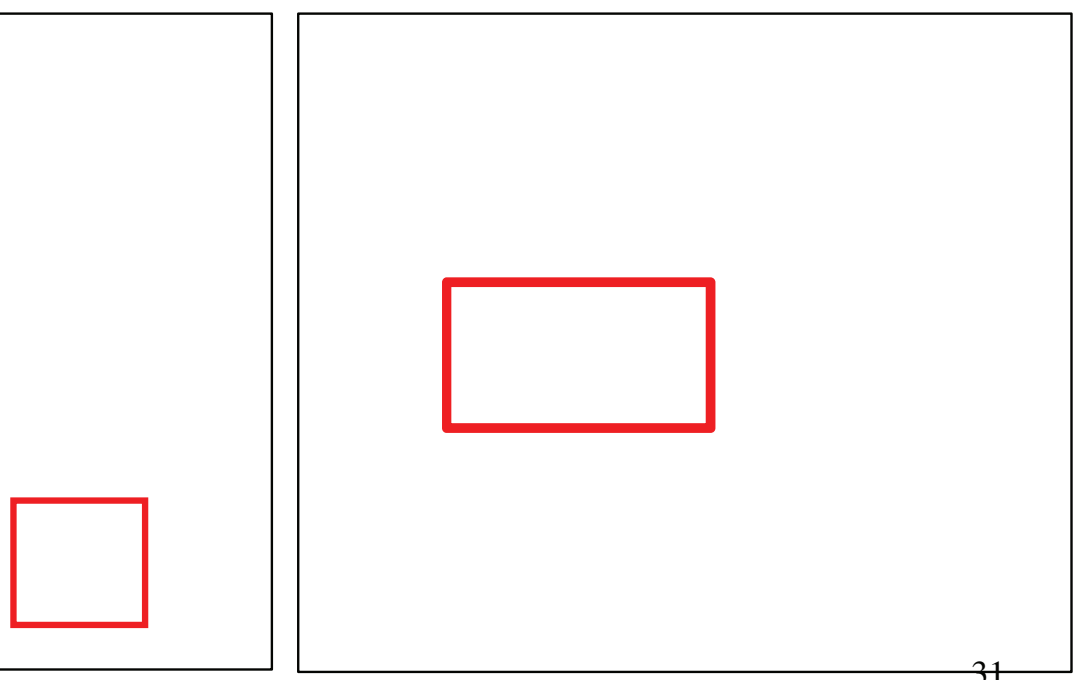

7 - Planta geral da cidade de São Paulo - 1916 (Secretaria de Estado, de Economia e Planejamento, Instituto Geográfico e Cartográfico - ICG. Acervo - Tombo: 1153) 

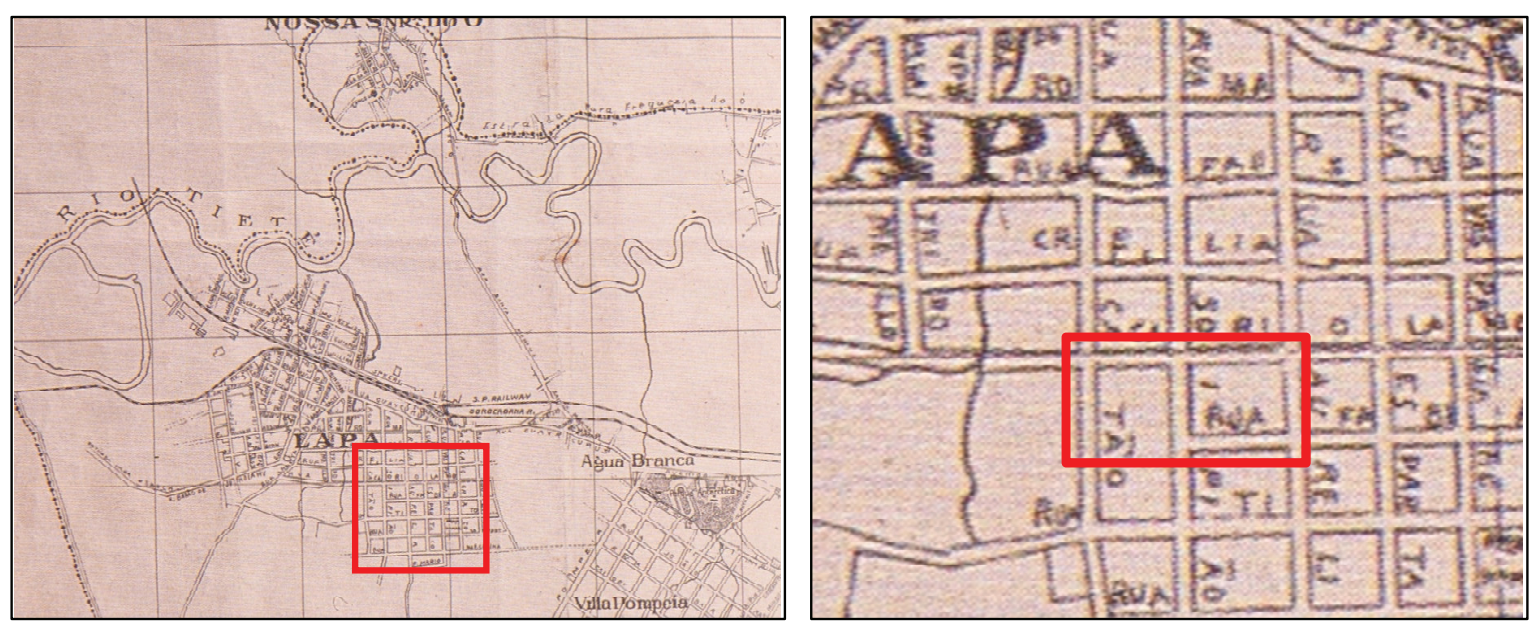

8 - Planta da cidade de São Paulo para indicador prático - 1922 (PASSOS \& EMIDIO 2009: 82-83)
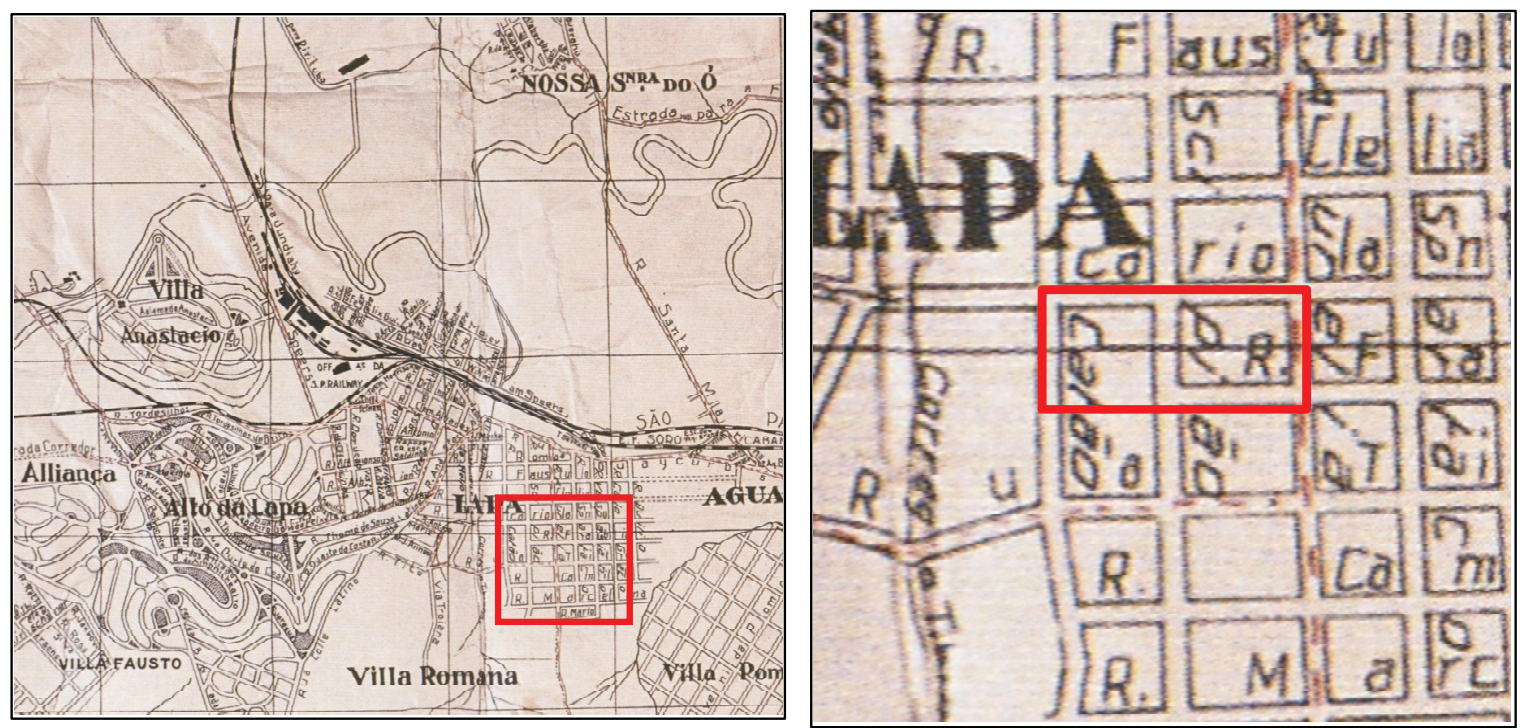

9 - Planta da cidade de São Paulo mostrando todos os arrabaldes e terrenos arruados - 1924 (PASSOS \& EMIDIO 2009: 84-85)
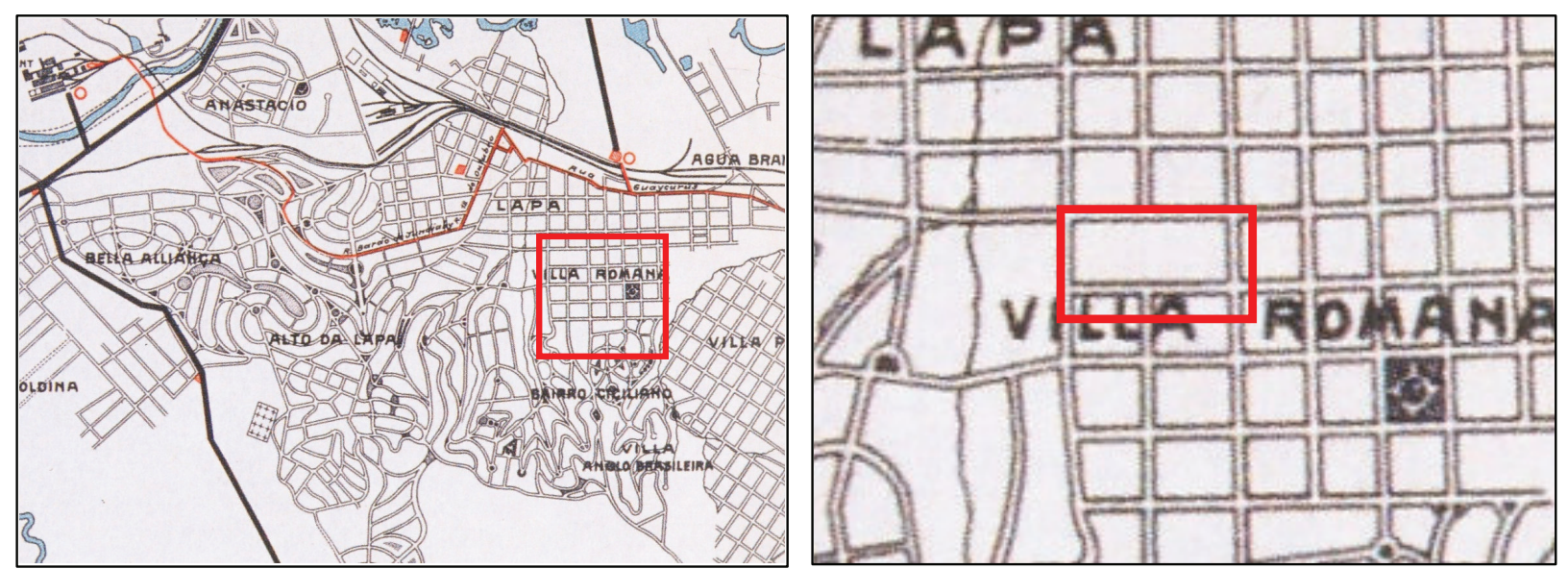

10 - Map of the city of São Paulo showing public utilities operated by subsidiary companies - 1924 (PASSOS \& EMIDIO 2009: 122-123) 

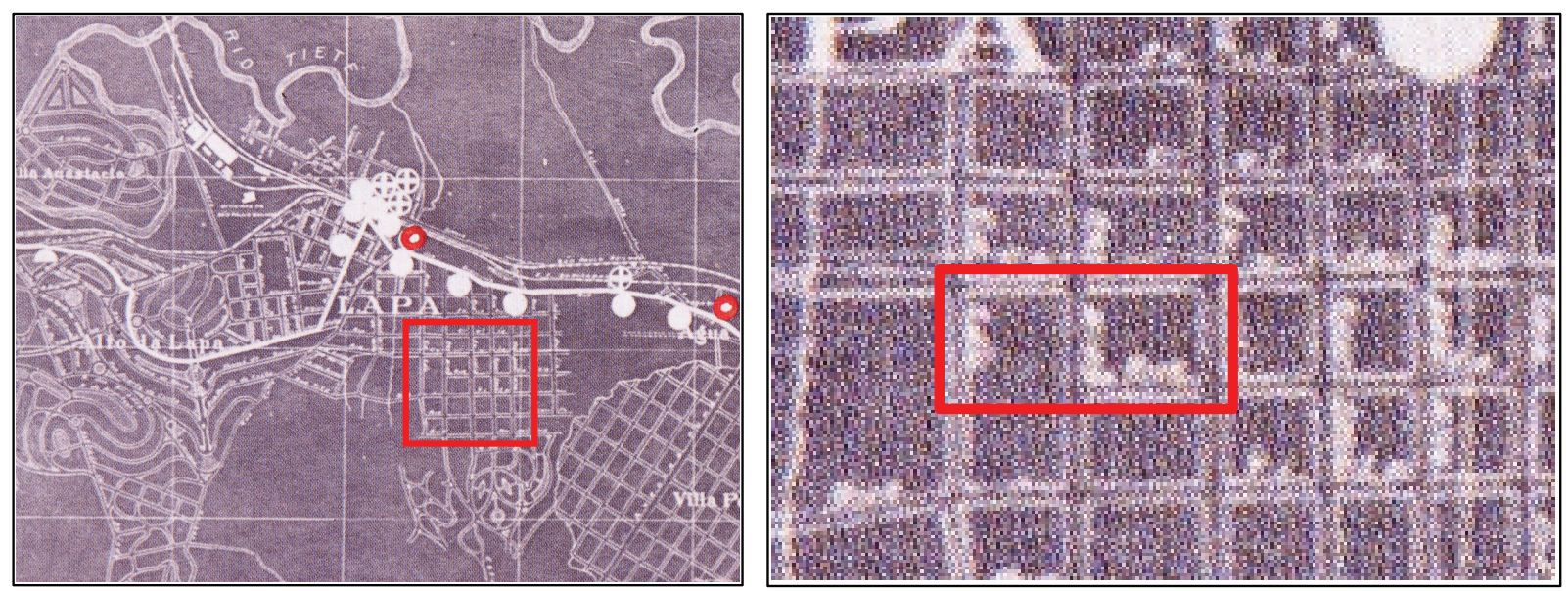

11 - São Paulo tramways: Origins of Traffic - 1925 (PASSOS \& EMIDIO 2009: 90-91)
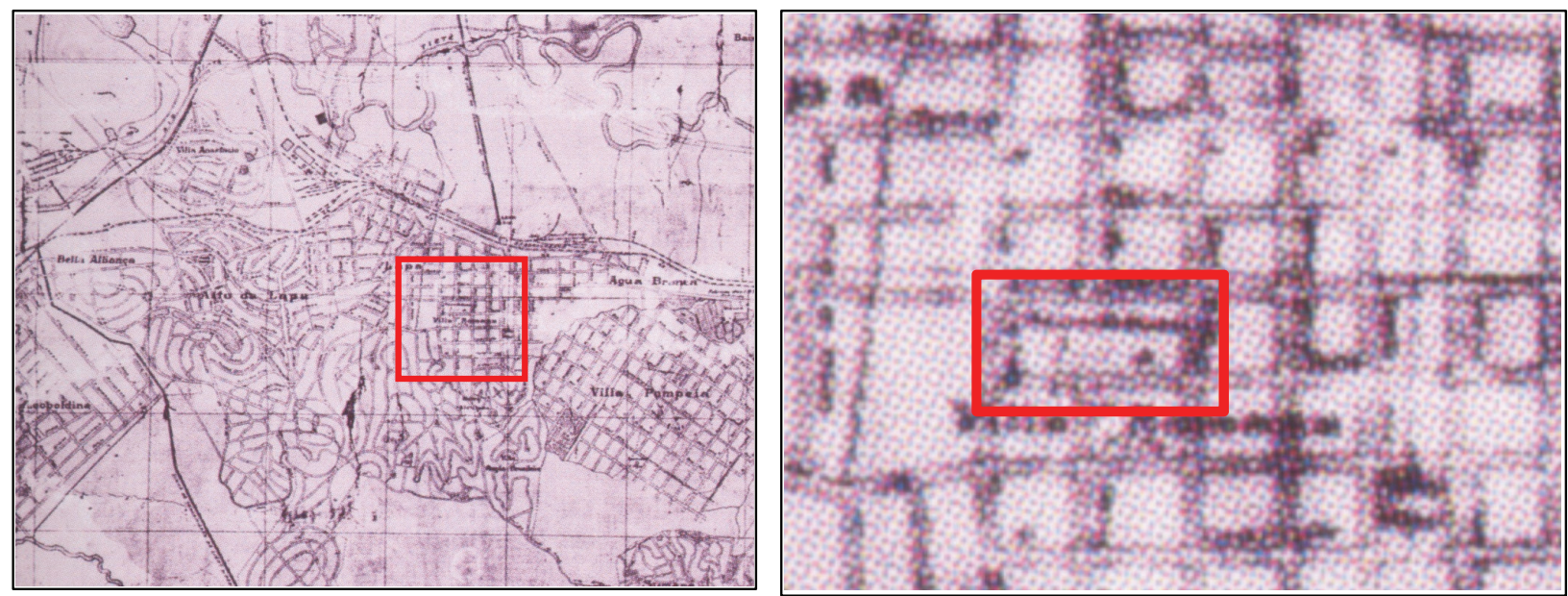

12 - Planta da cidade de São Paulo e municípios circunvizinhos - 1926 (PASSOS \& EMIDIO 2009: 97)
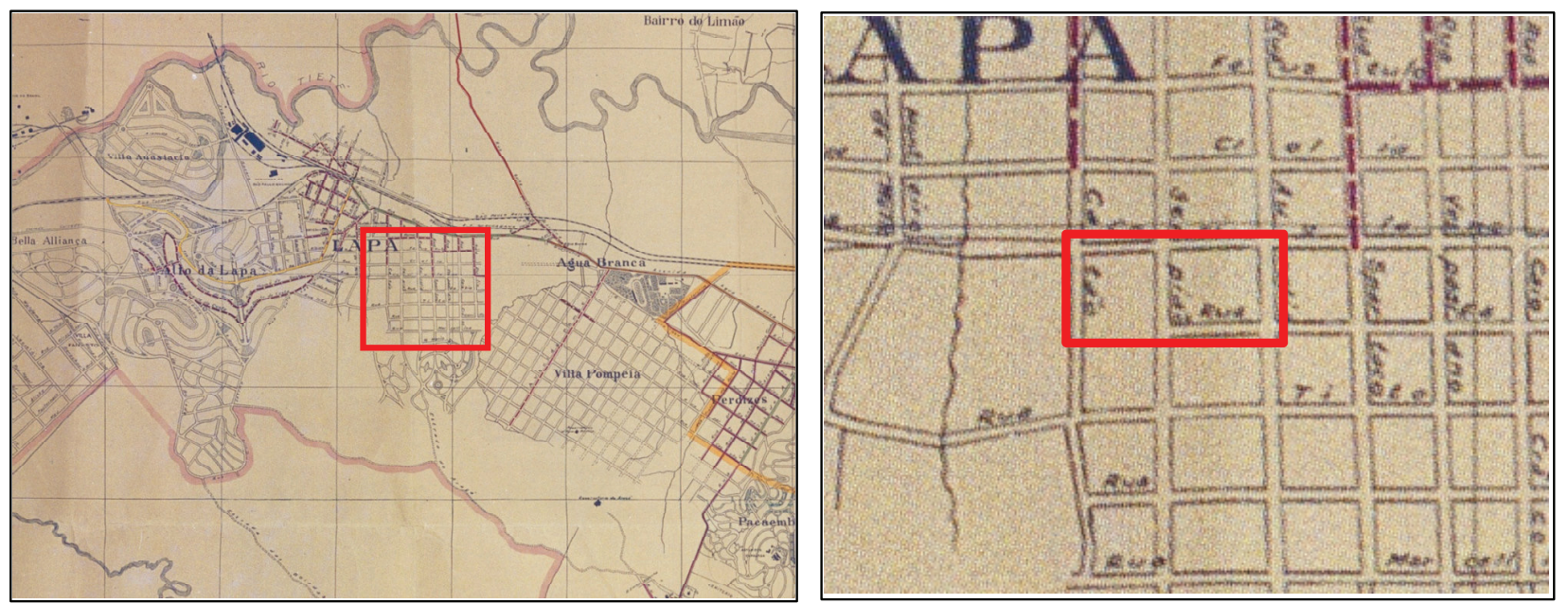

13 - Projeto preliminar para iluminação pública da cidade de São Paulo - 1926 (PASSOS \& EMIDIO 2009: 102-103) 
Com base nas plantas de 1905 e 1913 (plantas 1 a 3), nota-se a existência de uma possível construção no terreno, com fachada voltada para a rua Coriolano, anterior à ocupação da Fábrica Santa Catharina, mostrando que a área não era de todo inabitada (sede de uma chácara?). A quadra ainda não está completamente formada, faltando a continuação das ruas Aurélia, Catão e Fábia. A planta de 1914 (planta 4) marca com um ícone a presença, na quadra, da Fábrica de Louças Santa Catharina. Nela percebe-se os projetos de continuação das ruas Coriolano e Fábia em direção ao córrego do Mandy. A planta de 1916 (planta 6) representa as edificações que compunham a Fábrica, com fachadas voltadas para as ruas Coriolano, Fábia, Aurélia e a continuação da rua Cipião.

Apenas a partir da década de 1940, as plantas não mostram mais a quadra dividida por uma continuação da rua Cipião, nem o não prolongamento da rua Fábia até a rua Catão. Fixase, portanto, a configuração da quadra delimitada pelas ruas Catão, Aurélia, Fábia e Coriolano dentro da qual havia se estabelecido a Fábrica Santa Catharina. Deste modo, as plantas de número $1,2,3,10,12,14,15,17,18$ e 19 apresentam a quadra de 36 mil m² adquirida para a implantação da Fábrica (configuração 1); as plantas 8, 9, 11 e 13 a configuração 2; e as plantas 4, 5, 6, 7 e 16 a configuração de número 3. Portanto, a concomitância das três configurações.
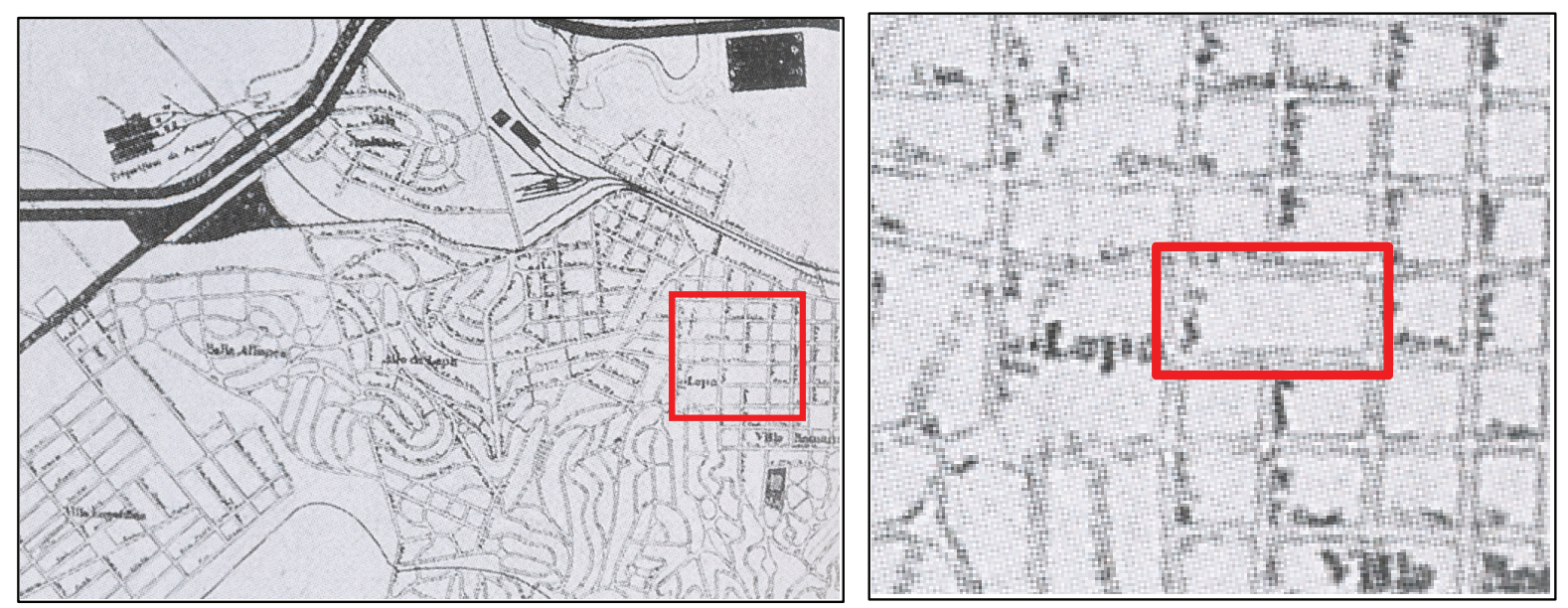

14 - Estudo de um plano de avenidas para a cidade de São Paulo - 1930 (PASSOS \& EMIDIO 2009: 138-139) 

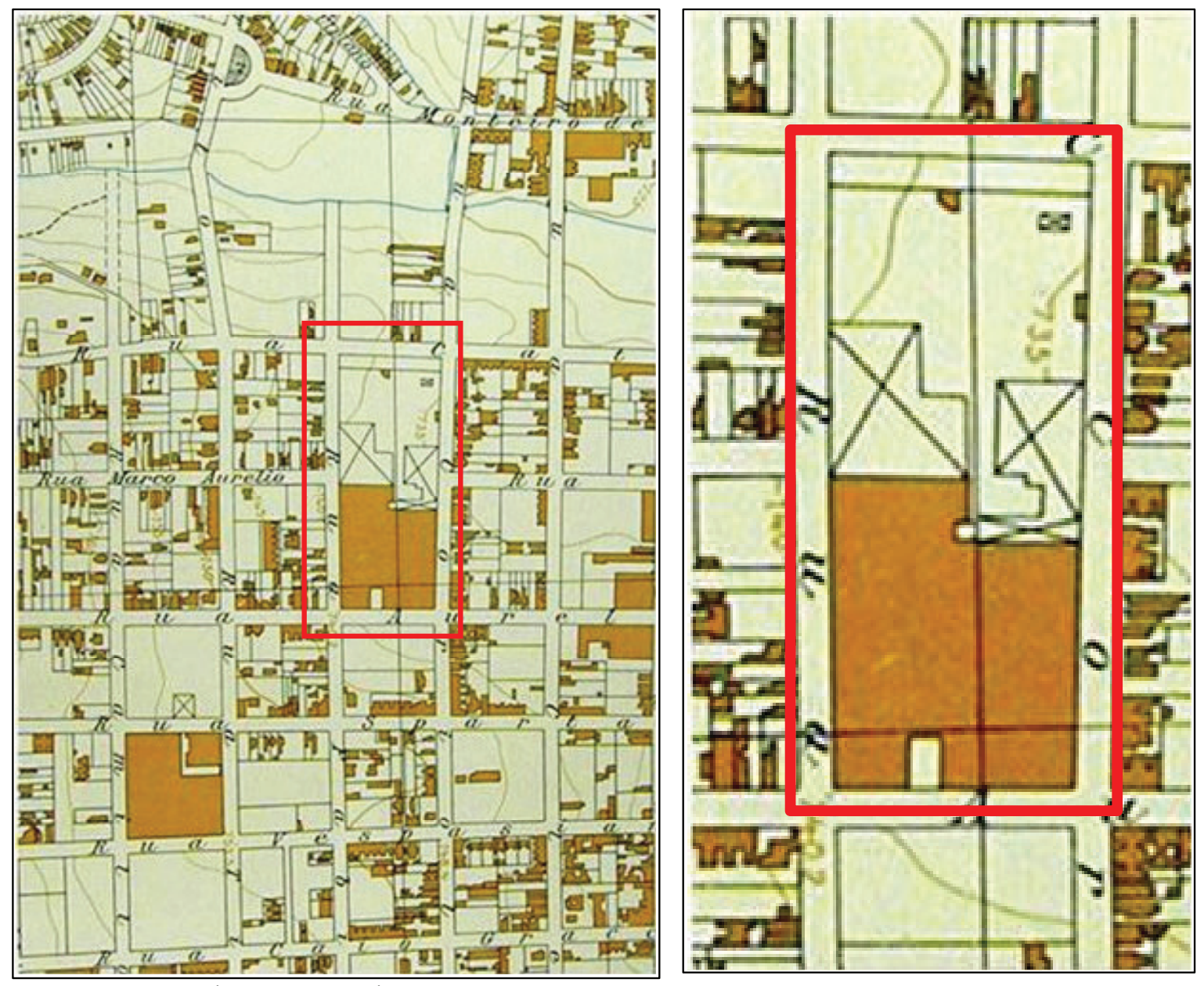

15 - Mapa Topográfico do Município de São Paulo - 1934. Levantamento do SARA BRASIL (ZANETTINI ARQUEOLOGIA 2003)
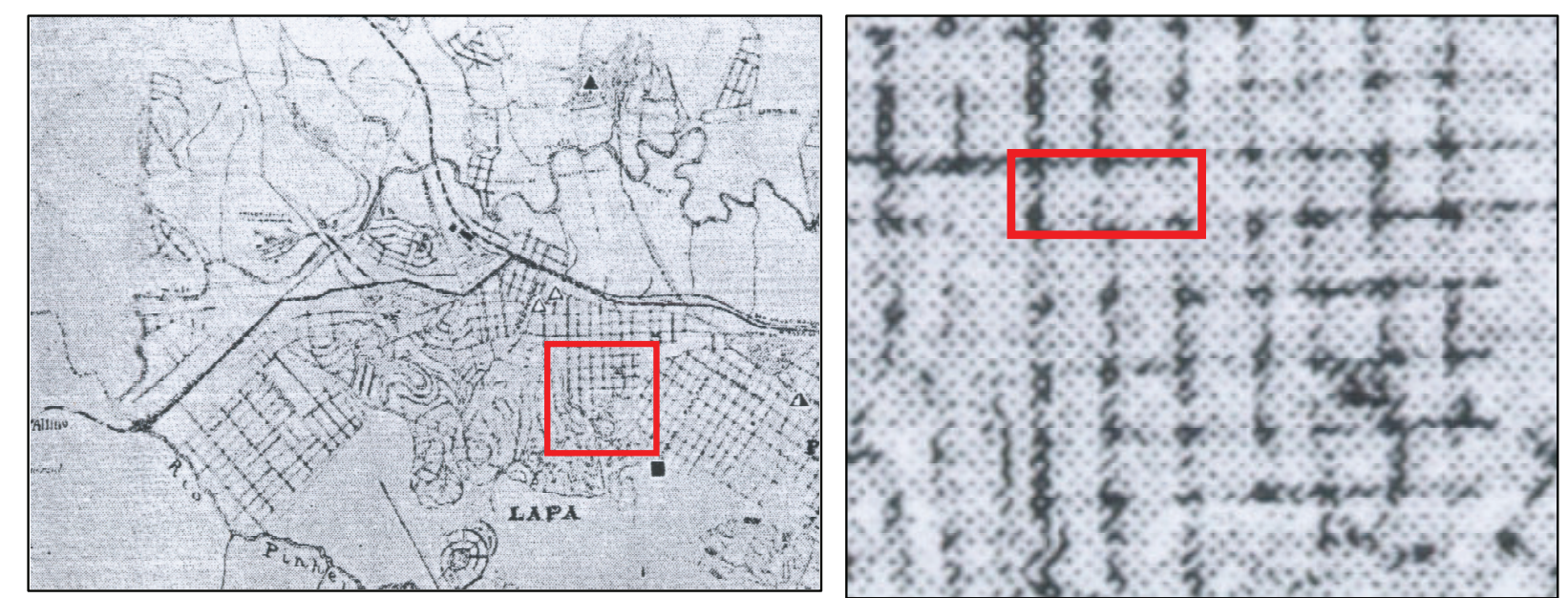

16 - Distribuição das instituições de assistência filantrópica na cidade de S. Paulo - 1935 (Revista do Arquivo Municipal, ano III, v. XXX) 

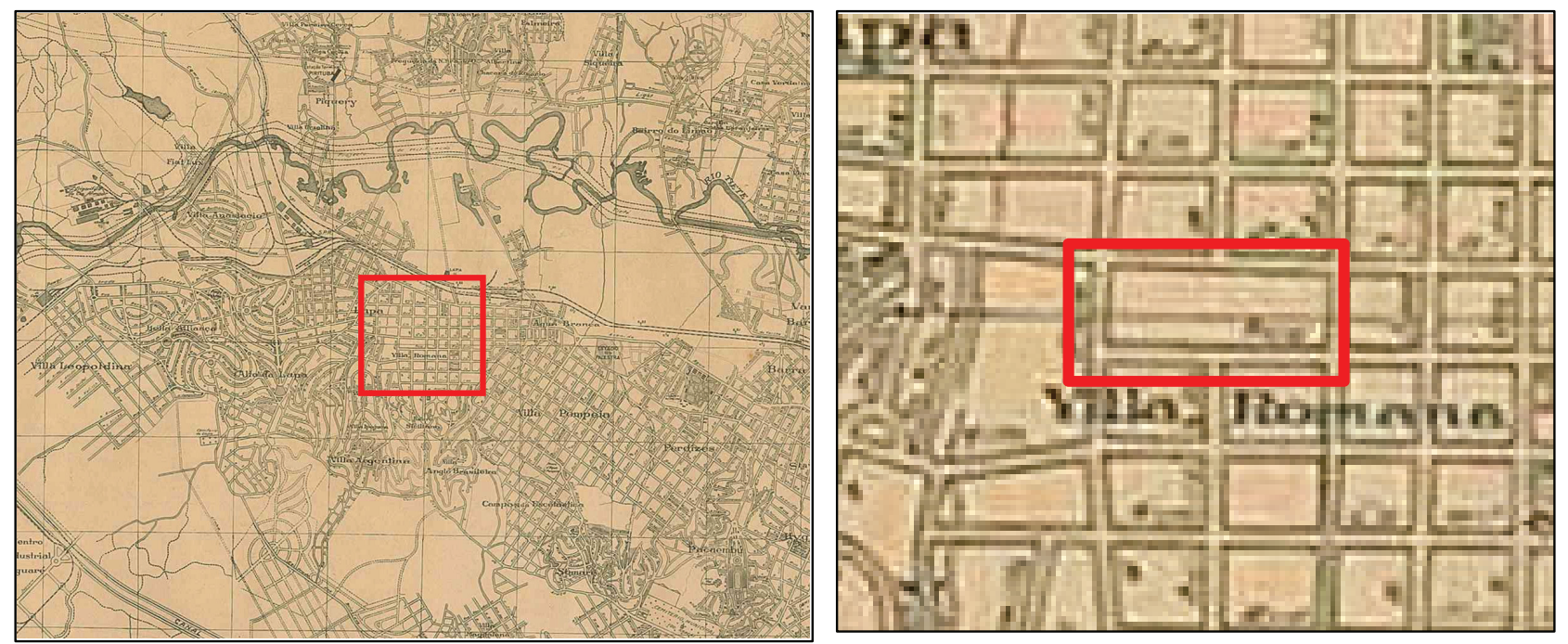

17 - Planta da cidade de São Paulo e municípios circunvizinhos - 1943 (Secretaria de Estado, de Economia e Planejamento, Instituto Geográfico e Cartográfico - ICG. Acervo - Tombo: 1153)
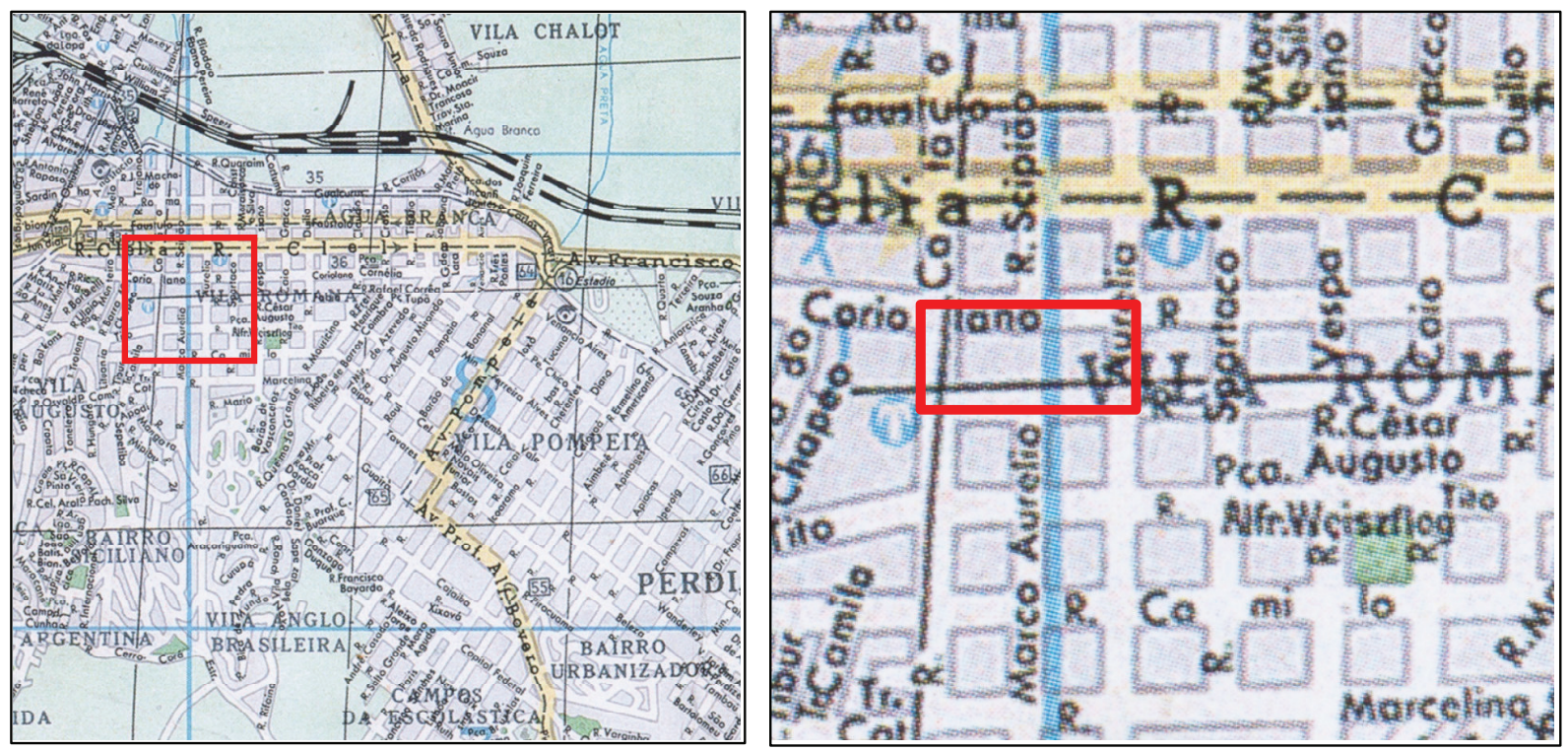

18 - São Paulo: projeção hiperboloid com rêde kilométrica - 1951 (PASSOS \& EMIDIO 2009: 154-155)
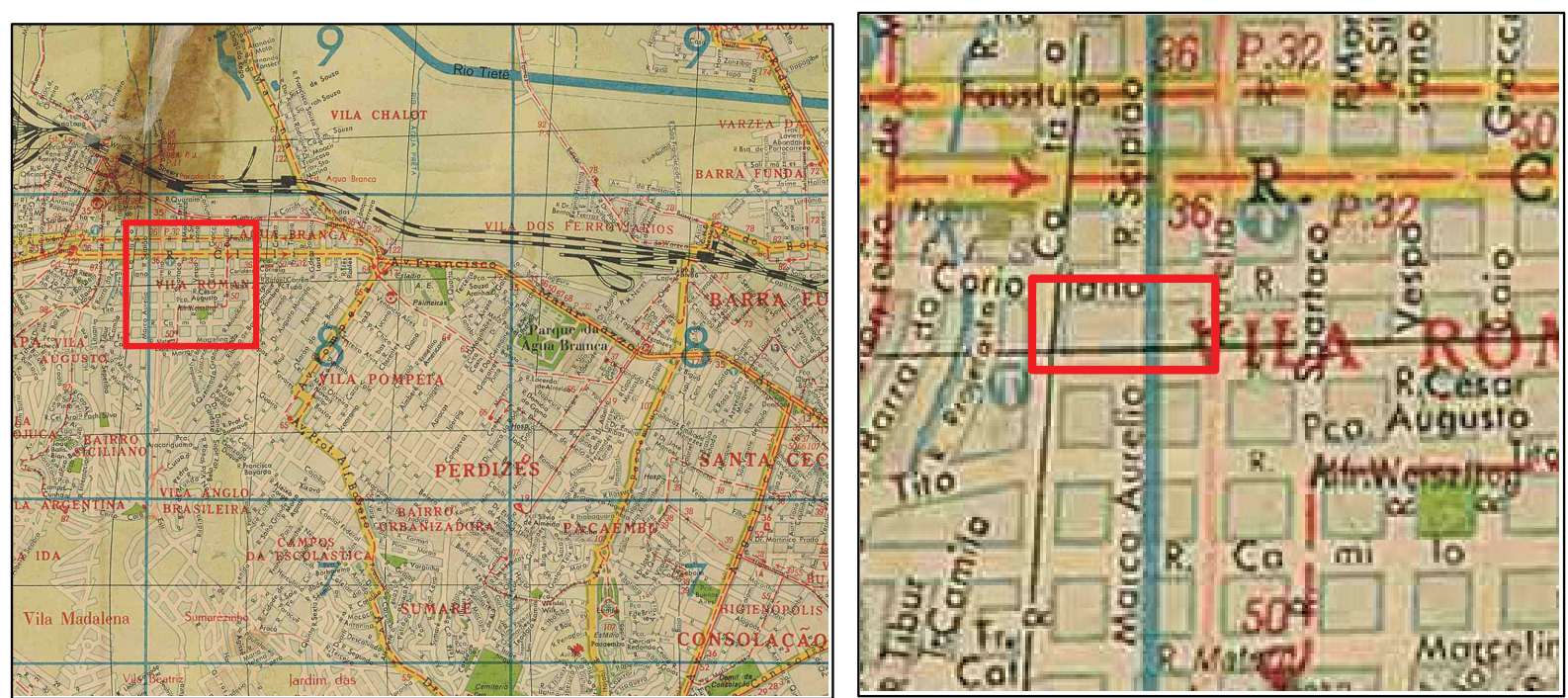

19 - São Paulo: projeção hiperboloid com rêde kilométrica - 1952 (Secretaria de Estado, de Economia e

Planejamento, Instituto Geográfico e Cartográfico - ICG. Acervo - Tombo: 1152) 
O levantamento do SARA BRASIL de 1934 mostra nitidamente a quadra inteira, retangular, que conteve a Fábrica Santa Catharina, já em seus anos finais, onde se pode ver a área dos galpões, voltada para a rua Aurélia, e as edificações com telhados (num total de 4 edificações telhadas, mais duas pequeninas construções), mais para oeste do terreno, onde haveria uma área livre.

Em 1963, o terreno é oficialmente dividido com a criação de duas passagens particulares que, mais tarde, chamar-se-iam rua Antônio Califari e rua Henrique Elkis; como comentei, a rua Antônio Califari talvez tenha sido efetuada sobreposta ao traçado de uma passagem já existente no local, como ficou claro observando-se as plantas anteriores, que marcam a presença de uma continuação da rua Cipião em direção a rua Marco Aurélio. A planta feita pela Emplasa em 1981 ainda apresenta as ruas como PSP-UM (futura Antônio Califari) e PSP-DOIS (futura Henrique Elkis). É possível, portanto, que estes locais de travessia da quadra, utilizados pela população local, existissem já desde o loteamento da Vila Romana, seguindo o leito do pequeno córrego, sendo fechados ou abertos de acordo com as etapas de ocupação da quadra. Por isso, talvez, as plantas antigas ora o marquem, ora não, dando a idéia de uma rua que ligava a Cipião à Marco Aurélio.

A partir dos anos 1960 as plantas mostrarão uma nova configuração do terreno e da quadra que conformava a Santa Catharina, a saber, um layout no qual constam 3 pequenas quadras, resultado da criação das duas ruas no sentido Norte/Sul, que passaram a conectar as paralelas Fábia e Coriolano. Deste modo, criou-se uma nova quadra que abarcou área pertencente a galpões, fornos e quintais, paulatinamente demolidos para dar lugar a habitações. Em época mais recente, a Petybon reocupou parte da área, sendo erguidas algumas edificações, como escritórios e almoxarifados.

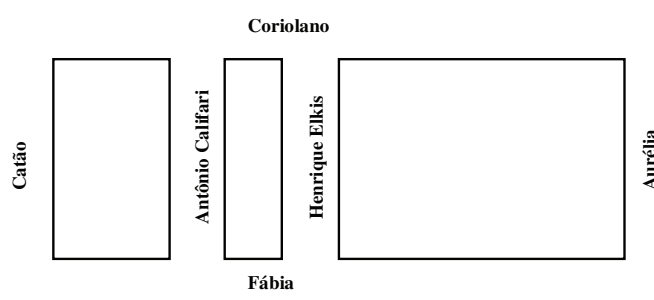

\section{Configuração 4}

Quando a quadra foi divida a partir dos anos 1960 em 3 quadras, com a criação de duas novas ruas (Antônio Califari e Henrique Elkis). 

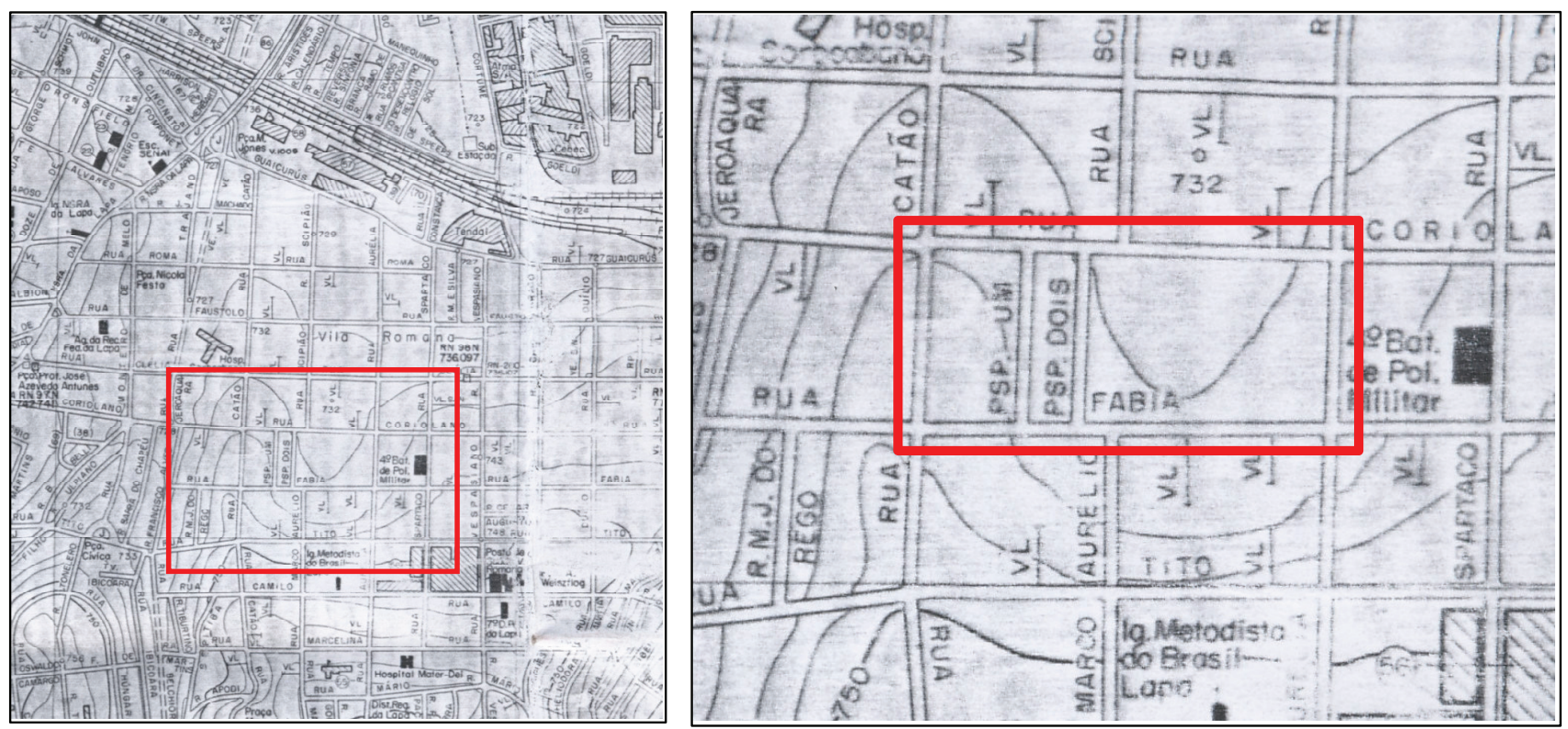

20 - Levantamento EMPLASA - 1981 (FFLCH/USP)

Todas estas configurações dialogam com o papel da quadra em relação a sua ocupação e a ocupação da Vila Romana e da Lapa. Em um primeiro momento, o terreno fora ocupado pela Fábrica de Louças Santa Catharina, fundada em 1913, tornando-se parte das Indústrias Reunidas Fábricas Matarazzo, quando de sua efetiva compra em 1927, até 1937. Neste ínterim, sofreu diversas reformas e ampliações; entre 1932 e 1939, por exemplo, os Matarazzo apresentaram à Prefeitura Municipal, 15 pedidos de autorização de obras em sua fábrica na Lapa, com destaque para a construção de um edifício para depósito, galpões, edifício para manipulação do caulim, instalações para um novo forno de aquecimento a quartzo e novas portarias (ZANETTINI ARQUEOLOGIA 2003).

Ao mesmo tempo em que buscou adaptar fisicamente a estrutura de produção da fábrica aos seus objetivos, o grupo Matarazzo também procurou regularizar a propriedade. Como, originalmente, o terreno era cortado pelo leito do rio que acompanhava o traçado da rua Cipião e, depois, num determinado momento, foi canalizado e coberto, foi necessário incorporar à área da Fábrica suas margens, então propriedade da Prefeitura (fato ocorrido provavelmente já na fase sob ocupação da Santa Catharina, conforme dados arqueológicos). Em setembro de 1933, através de escritura pública, é feita uma permuta onde as IRFM transmitem à Prefeitura "uma área de terreno situada à rua Fábia, esquina com Catão", parte posterior do terreno da Fábrica, em troca do terreno que fazia parte da rua Cipião. 
Com a morte do Conde Matarazzo, em 1937, e a aquisição de jazidas de caulim no $\mathrm{ABC}$, as IRFM encerram as atividades na Fábrica da Vila Romana e passam a produzir louças em São Caetano, na Fábrica de Louças Cláudia. Em 1937, as Indústrias Matarazzo, ainda no processo de desdobramento e diversificação das atividades, criam a empresa Indústrias Alimentícias Petybon Ltda., para produzir massas e biscoitos.

No início dos anos 60, o Grupo Matarazzo, resolvendo um problema de herança familiar, vendeu, em 1963, parte do lote originalmente ocupado pela Fábrica Santa Catarina. Foram abertas as duas passagens particulares, atuais ruas Henrique Elkis e Antônio Calafiori, e a face voltada para a rua Catão foi loteada e vendida. Outra porção do terreno, voltada para a rua Fábia, provavelmente vendida na mesma época, foi ocupada por uma malharia.

As Indústrias Matarazzo já não dispunham, nos anos 1970, do mesmo vigor dos anos anteriores, especialmente da fase de expansão do começo do século XX. A morte de Francisco Matarazzo Jr., em 1977, veio a agravar a crise vivida pelo grupo industrial; sua filha e sucessora no controle das empresas não conseguiu impedir o desmoronamento do império e, no início dos anos 1980, foi solicitada a concordata. Atualmente, a única unidade fabril em operação do grupo produz os sabonetes Francis, em Santa Rosa do Viterbo, Estado de São Paulo. Ainda em 1977, no processo de adequação do grupo à crise interna, as IRFM hipotecaram o terreno e o prédio industrial da Fábrica de Biscoitos Petybon, localizado na rua Coriolano, para o Lloyds Bank International Limited. Em 1979, a Matarazzo se associou a uma empresa americana fabricante de chocolates e massas - a Hershey - para fabricar massas, biscoitos, margarinas e achocolatado líquido (ZANETTINI ARQUEOLOGIA 2003).

Em 13 de janeiro de 1983, a Matarazzo solicitou o cancelamento da hipoteca do imóvel junto ao Loyds Bank e, na mesma data, o vendeu para a Companhia Mofarrej de Empreendimentos. A Petybon, associada à Hershey, permaneceu produzindo sua linha de alimentos na fábrica quando, em dezembro de 1986, o grupo Matarazzo vendeu a empresa para o grupo Bunge, de origem holandesa e sucessores do Moinho Santista. A Petybon Indústrias Alimentícias S/A passou, então, a denominar-se Petybon S/A e manteve a linha de produção de biscoitos na fábrica da Lapa. Em janeiro de 1987, a Petybon assinou um contrato de locação por quatro anos com a proprietária do imóvel, a Companhia Mofarrej.

Em junho de 1988, a Petybon associou-se à Mapa S/A (Mapiant, indústria italiana de massas) e formou a Petymapa, com uma participação de 65\% por parte da Petybon. Em março de 1990, a Companhia Mofarrej renovou a locação do imóvel da fábrica para a Petybon por mais 36 meses. Em julho do mesmo ano, a Petybon criou, com a BSN francesa, 
uma joint-venture que resultou na General Biscuits of Brazil - GBBr. A produção conjunta na fábrica da Lapa (Petybon/BSN) foi iniciada em 1991. Em 1992, a Companhia Mofarrej assinou um novo contrato de locação do imóvel com a $\mathrm{GBBr}$ por 24 meses (ZANETTINI ARQUEOLOGIA 2003).

Ocupando um imóvel alugado e utilizando equipamentos ultrapassados, a $\mathrm{GBBr}$ pôs à venda, em 1993, sua fábrica de biscoitos. A unidade, mas não a marca, foi adquirida pelo grupo Parmalat. A Yolat Indústria e Comércio de Laticínio Ltda. (grupo Parmalat) sucedeu a GBBr na qualidade de locatária do imóvel. A Parmalat deixou de produzir nas instalações em 2000, mas só em abril de 2002 foi cancelada a locação à pedido da Companhia Mofarrej de Empreendimentos. Em novembro do mesmo ano a Mofarrej demoliu os edifícios da unidade industrial desativada (ZANETTINI ARQUEOLOGIA 2003).

Em 19 de maio de 2003, a Companhia Mofarrej registrou, no $10^{\circ}$ Cartório de Registro de Imóveis de São Paulo, a incorporação imobiliária denominada "Condomínio Paradiso Vila Romana" à rua Fábia n ${ }^{\circ}$ 800, composta de três edifícios de 29 pavimentos, com subsolo e andar térreo comuns aos três. 


\section{SUB-CAPÍTULO 1.3}

\section{UM ATERRO DE LOUÇAS NA CIDADE}

É sabida a complexidade da formação dos solos em perímetro urbano; quando nos referimos a estratigrafias de sítios arqueológicos urbanos, esta complexidade aumenta tendo em vista as rápidas ações a que o registro arqueológico na cidade está sujeito, ações eminentemente de caráter antrópico. O dinamismo das áreas urbanas gera uma "estratigrafia arqueológica extremamente complexa" (JULIANI, 1994-5: 366). Andrea Carandini sabiamente chamou os sítios arqueológicos urbanos de "ilhas estratigráficas humanas num mar de estratos naturais" (CARANDINI 1991: 38); a sobreposição de camadas arqueológicas artificiais é uma característica de qualquer meio urbano e constitui a essência da Arqueologia Urbana (ZANETTINI ARQUEOLOGIA 2005: 34). Esta constante possibilidade de que um estrato se transforme em outro é parte da historicidade do nosso subsolo (CARANDINI 1991: 38), transformando o meio em paisagem, onde se manifesta a dialética entre ações humanas e os atos da natureza. Práticas são mantidas ou modificadas, decisões são tomadas e idéias ganham forma: "a landsape retains the physical evidence of these mental activities" (CRUMLEY 1994a apud BALÉE \& ERICKSON 2006: 2). O uso de aterros é um exemplo disso. A estratigrafia dos sítios históricos urbanos, geralmente reocupados sucessivamente, é marcada pela presença dos aterros.

Devido sua localização, no interior da urbs, pelo menos até a década de 1970, a Arqueologia não se interessava por sítios urbanos por considerá-los "destruídos" ou "sem potencial arqueológico". Para Salwen (1978: 458), informações de vários períodos do passado humano existem nestes lugares que, até alguns anos atrás, a maioria dos pesquisadores considerava destruída - tais quais rodovias, terrenos com construções, áreas aradas, etc. (CALDARELLI 2003). "Todo sítio deve ser considerado como portador de informação até que se prove o contrário" (ARAÚJO 2001/2002: 10).

Deste modo, alguns estudiosos começaram a descobrir, como Staski (1999), que os assentamentos urbanos geralmente apresentam boa preservação do registro arqueológico (JULIANI 1994-5: 370). A Arqueologia Urbana passou a trabalhar com a hipótese de que a pavimentação e a chegada do asfalto podem ter protegido alguns sítios e que distúrbios podem apenas ter ocorrido na fina camada superficial, escondendo importantes sítios arqueológicos e deixando muitas de suas características (SALWEN 1978: 454). De duas uma: 
ou a era industrial complicou demais a estratigrafia ou a simplificou ao extremo (CARANDINI 1991: 42).

Com a evolução urbana e o crescimento das ocupações, é indubitável a presença de objetos em sub-superfície e, quando nos referimos às cidades, especialmente materiais cerâmicos construtivos resultantes das diversas demolições e construções. Segundo Schiffer, a cidade é o locus onde quase nenhum elemento é descartado em seu lugar de uso, fazendo com que, conseqüentemente, quase todo contexto arqueológico material seja um refugo secundário (SCHIFFER 1972). Como pontuou Stanley South (1994: 79), não se deve escavar um sítio apenas para revelar a arquitetura, os estratos arqueológicos e os artefatos, mas igualmente para entender os amplos processos revelados e a relação entre eles.

Não foi diferente com o sítio Petybon. As escavações revelaram uma estratigrafia bastante complexa, com inúmeras camadas que se sobrepõem e se superpõem, indicando as diversas fases de ocupação do terreno, com impactos sobre o sítio arqueológico. Encaro, aqui, todo o registro arqueológico como "um fenômeno contemporâneo constituído de vestígios materiais que foram formados, transformados e depositados a partir de diferentes fatores naturais e culturais, chamados de processos de formação" (SILVA 2000: 179). Meu objetivo neste item, dessa maneira, é realizar algumas incursões em torno da formação do registro arqueológico do sítio Petybon, com foco nos processos culturais de formação, discorrendo sobre a natureza da estratigrafia do sítio assim como das estratégias implementadas pelos ocupantes do terreno para conformá-lo segundo diferentes funções, visões de mundo e imprevisíveis motivações (CARANDINI 1991: 42).

Antes de tudo, é necessário apresentar os resultados obtidos pelas intervenções arqueológicas, com base na divisão do terreno em zonas de potencial arqueológico. Para apresentar os perfis das unidades de escavação do sítio, utilizei a metodologia da matriz Harris $(1975$; 1979), pois achei que apresentá-los através dos fluxogramas proporcionaria uma visão mais clara dos estratos e da estratigrafia, diferente de fotos ou desenhos dos perfis, porque, neste caso, como há muitas camadas, o perfil acaba tornando-se um caleidoscópio de cores e texturas.

Na zona de baixo potencial, na porção mais a leste do terreno, a densidade de artefatos móveis mostrou-se baixa, inversamente proporcional a presença de elementos estruturais como remanescentes de baldrames (construídos com tijolos e argamassa de cimento ou concreto armado), presença de canaletas, tubulações de água (algumas em PVC) e caixas de concreto abertas pela Petybon para estoque de matéria-prima (banha, farinha, etc.). O que se 
observou na estratigrafia desta zona foi a presença de sucessivas camadas de obras para implantação dos edifícios, que resultou na presença de restos dos embasamentos das construções com suas redes de tubulação associadas às atividades no interior dos prédios.

Uma vez que esta foi a zona, no terreno, de primeira implantação de edificações, especialmente galpões, não espera-se que abaixo disso haja a presença de vestígios móveis, louças, já que a Fábrica ainda não produzia ou descartava seus produtos concomitante ou anteriormente a presença dos prédios.

No que concerne à zona de médio potencial arqueológico, mais a oeste do terreno, a estratigrafia caracterizou-se por sequiências bem delineadas de camadas de aterramento, aplicadas para proporcionar a elevação da cota original e o distanciamento/impermeabilização do local, outrora cortado por uma drenagem natural, com objetivo de incorporá-la ao complexo, dando-lhe funcionalidade. Como disse, a drenagem foi canalizada e transformada em galeria subterrânea, alinhada a rua Cipião e Marco Aurélio, para onde afluem as tubulações de águas pluviais do terreno. Percebeu-se também, que mediante a retificação e o aterramento, o local foi parcialmente ocupado por edificações, servindo de pátio aberto para carga, descarga e descarte de material. Daí a presença de níveis com material arqueológico móvel, louças, abaixo dos vestígios de estruturas construtivas, como baldrames, pois a produção já existia, e descartou o material em terreno posteriormente ocupado pelas edificações (de acordo com as expansões da Fábrica). Os níveis mais superficiais dos perfis estratigráficos eram camadas de piso de concreto, ou entulhos resultantes de demolição, daí a necessidade de emprego da retro-escavadeira para abertura das unidades.

Nesta zona, boa parte das unidades de escavação atingiu o nível freático (numa média de $70 \mathrm{~cm}$ de profundidade). Foram diagnosticados dois níveis distintos de deposição de descarte de refugo cerâmico. Um mais profundo, apresentando continuidade no sentido Leste/Oeste, conformando uma camada contínua e espessa de fragmentos bastante diminutos. Nesta camada, predomina a louça de segunda queima (vidrada), empregada como elemento drenante.

Já nas camadas mais superficiais, em alguns casos situadas imediatamente abaixo de piso de tijolos (intercalado por camadas mais recentes de concreto e cimento), observou-se a existência de estruturas diferenciais de refugo, pontuais, derivadas da dejeção e empilhamento do material descartado para o eventual preenchimento de valas, buracos e 
correção de depressões anterior à pavimentação da área, originalmente utilizada para lançamento de refugo, galpões de lenha, etc.

Na porção mais próxima da Rua Coriolano, conta-se com uma estrutura alteada, destinada a refeitório da Fábrica da Petybon. A unidade de escavação 2 incidiu sobre a base da edificação suprimida, que se deu mediante a indicação da análise geofísica, cujos dados apresentaram extrema dificuldade de leitura e interpretação. Sinais atenuados apontavam para a possível existência, no local, de um grande bolsão rico em artefatos. No interior da unidade foram evidenciados, ainda, trechos de piso cerâmico remanescente e evidências associadas que indicavam a presença de instalações sanitárias. Após a retirada do piso mais recente, alguns trechos apresentaram a mesma performance, com a presença da camada contínua composta por refugo cerâmico moído.

\section{Unidade de Escavação 10}

Perfil N

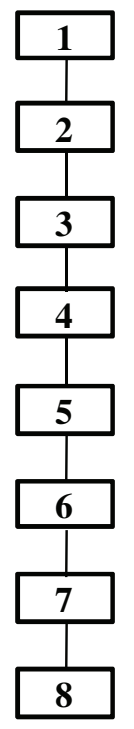

\begin{tabular}{|l} 
1. Aterro: sedimento arenoso, \\
pulverulento, com inclusões de brita \\
2. Aterro: sedimento areno-argiloso, \\
compactado, cor avermelhada \\
3. Fiada de tijolos maciços \\
4. Aterro: sedimento areno-argiloso, \\
compactado, cor avermelhada \\
5. Aterro: sedimento areno-argiloso, \\
compactado, cor avermelhada, com \\
inclusões de pequenos seixos e \\
fragmentos de carvão \\
6. Aterro: sedimento areno-argiloso, \\
compactado, cor avermelhada \\
7. Piche e presença de fragmentos de \\
manilha de grès \\
8. Sedimento areno-argiloso, \\
compactado, cor marromSolo \\
arenoso marrom escuro
\end{tabular}

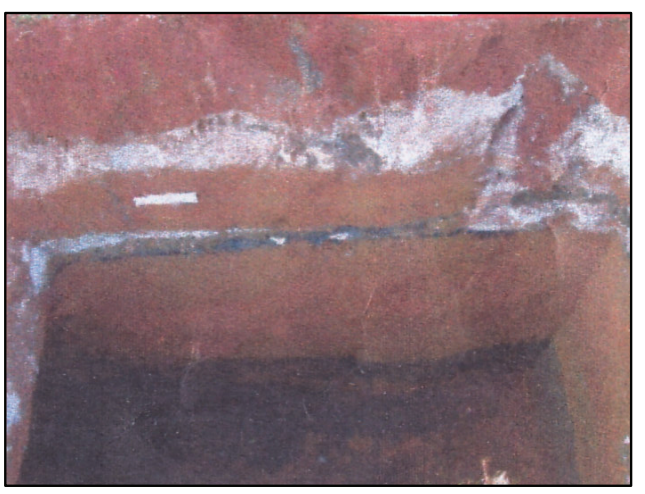

Unidade de Escavação 6

Perfil N

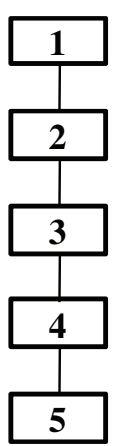

1. Aterro: sedimento arenoso, pulverulento, com inclusões de brita

2. Aterro: sedimento areno-argiloso, compactado, cor avermelhada

3. Construção de tijolos maciços

4. Aterro: sedimento areno-argiloso, compactado, cor marrom claro, com inclusões de entulho construtivo (telhas, tijolos, manilhas)

5. Aterro: sedimento areno-argiloso, compactado, cor avermelhada

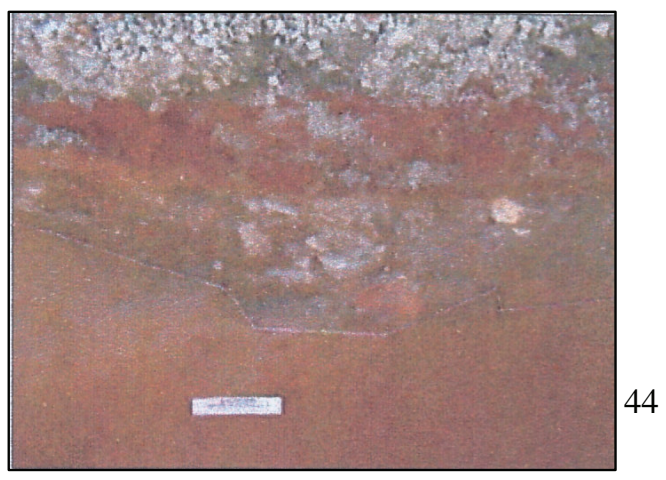


Unidade de Escavação 23

Perfil L

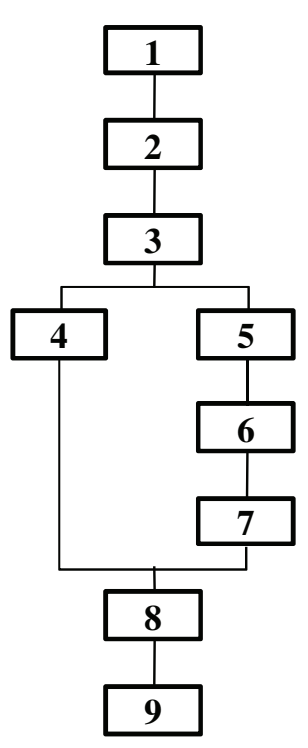

1. Aterro: sedimento areno-argiloso, compactado cor avermelhada

2. Aterro: entulho de material construtivo (cimento, tijolos e fragmentos de rochas)

3. Piso de concreto

4. Aterro: sedimento areno-argiloso, compactado, cor marrom claro, com entulho construtivo (telhas, tijolos, manilhas e pedras) e fragmentos de louça

5. Construção de tijolos maciços

6. Aterro: sedimento areno-argiloso, cor marrom escuro com entulho construtivo (telhas, tijolos, manilhas) e louças

7. Construção de tijolos correspondente a um duto de água (construída com tijolos com a marca da Fábrica de Louças Santa Catharina [estrela de seis pontas com FLSC])

8. Sedimento areno-argiloso, compactado, cor avermelhada, arqueologicamente estéril

9. Nível do lençol freático

Unidade de Escavação 24

Perfil L

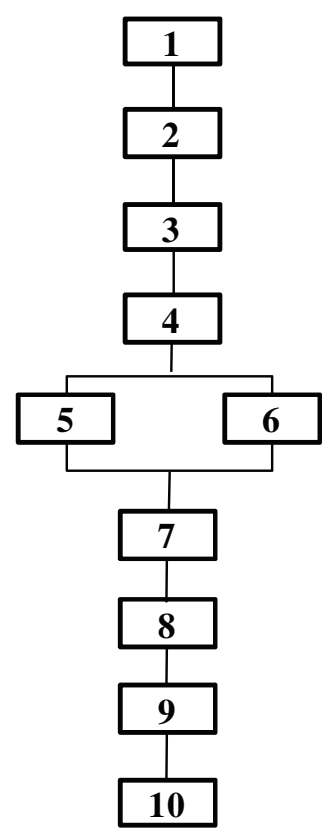

1. Aterro: sedimento areno-argiloso, compactado, cor avermelhada

2. Piso de concreto

3. Aterro: entulho construtivo (cimento, tijolo e pedras)

4. Fundação de tijolos maciços

5. Fundação de tijolos maciços

6. Aterro: sedimento areno-argiloso, compactado, cor marro claro

7. Caulim

8. Sedimento marrom escuro com inclusão de fragmentos de carvão

9. Sedimento areno-argiloso, compactado, cor marrom escuro

10. Nível do lençol freático

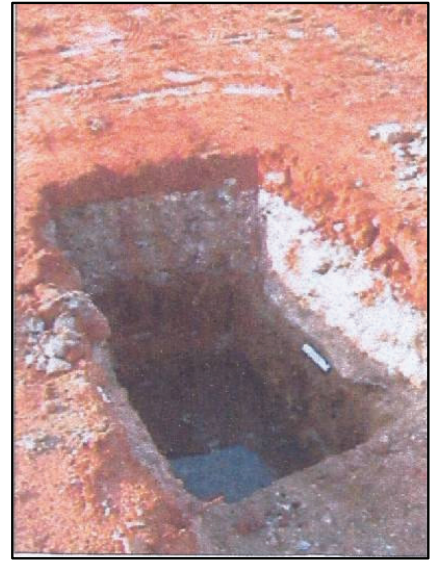

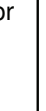




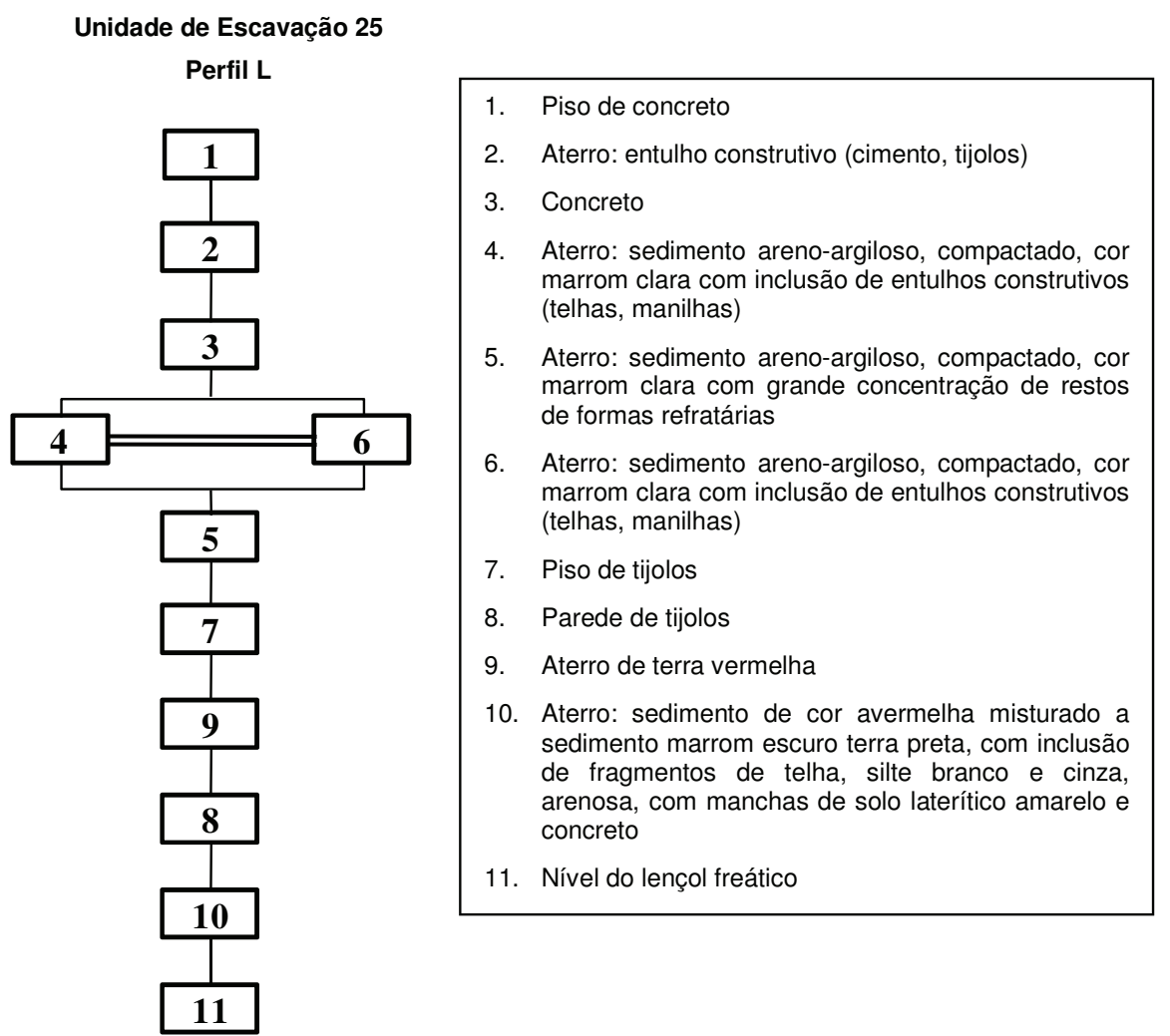

Por fim, na zona de alto potencial arqueológico, no extremo oeste da propriedade, a camada de aterramento difere da seqüência observada nas demais unidades de escavação, sendo composta por um pacote espesso de terra argilosa escura, rica em cinzas e carvões, associadas a cacos de louça e azulejos, indicando a provável proximidade de um dos fornos outrora existentes. Abaixo dessa camada, contou-se com evidências de estruturas de tijolos, dentre elas uma canaleta construída com tijolos e argamassa de barro que se prestou, no passado, ao lançamento e escoamento de fluídos, ricos em pigmentos, sendo efetuada a coleta, no interior da mesma, de material para análises laboratoriais. Na intersecção das unidades de escavação 29 e 32 (que define a transição da zona de média densidade para a de alta densidade de material), foi identificado um bolsão de refugo de louça bastante preservado.

Ocorre que com a venda de parte da propriedade e a alteração do layout da Fábrica, o local destinado aos galpões de argila e fornos maiores foi sendo paulatinamente demolido para dar lugar a habitações, sendo abertas duas pequenas vielas. Numa fase mais recente, a área da Petybon foi reocupada, sendo erguidas edificações mais delgadas, destinadas a escritórios e almoxarifado. Na fase final de ocupação, essa zona contou com edificações menores, destinadas a escritórios comerciais, departamento de pessoal e outras funções 
administrativas, conforme atestam os indícios em superfície e nos muros confrontantes (marcas de estruturas de tijolos, pisos do tipo zetaflex, caixas plásticas de passagem de energia, datáveis, portanto, dos anos 1960/1980). Além da louça em profusão, as camadas de entulho cerâmico apresentam peças relacionadas ao cotidiano de produção ou ao chamado mobiliário de forno (caixas refratárias, caulim, suportes, etc.). Em alguns pontos, o material de refugo atuou como contra piso para a aplicação de concreto, apresentando fragmentos agregados ao mesmo.

O último nivelamento ocorrido nesse pátio, em parte descoberto, deriva provavelmente da transição da modalidade industrial de cerâmica à unidade de produção de gêneros alimentícios, processo que se desenrolou a partir dos anos 1940, já sob os desígnios das IRFM (Petybon). Em uma fase anterior, foi aplicado um piso em tijolos.

Unidade de Escavação 3

Perfil L

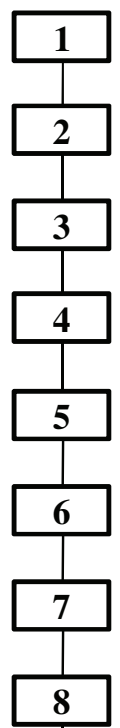

$$
\begin{aligned}
& \text { 1. Piso de azulejo } \\
& \text { 2. Concreto }
\end{aligned}
$$

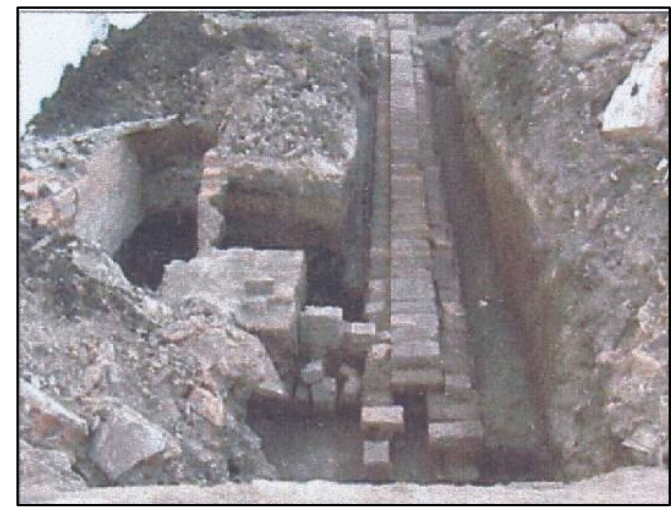

Unidade de Escavação 4 Perfil L

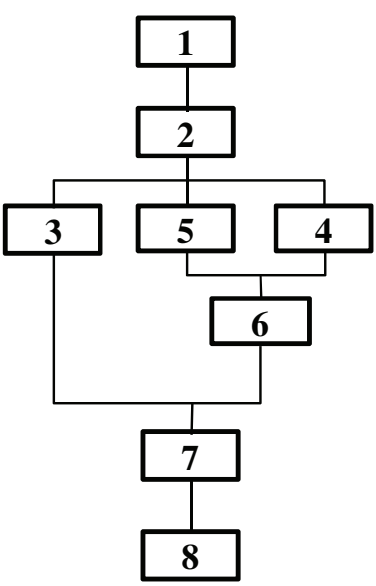

1. Aterro: entulho de material construtivo (cimento e tijolos)

2. Aterro: sedimento areno-argiloso, compactado, cor marrom escuro

3. Aterro: sedimento areno-argiloso, cor acinzentado com inclusão de entulho construtivo (telhas, tijolos, manilhas)

4. Aterro: sedimento areno-argiloso, cor acinzentado com inclusão de entulho construtivo (telhas, tijolos, manilhas)

5. Bolsão de argila

6. Bolsão de louças bem preservadas misturado com sedimento marrom escurlo, argila cinza e restos de formas refratárias

7. Aterro: sedimento areno-argiloso, compactado, cor marrom escuro

8. Rampa de tijolos maciços

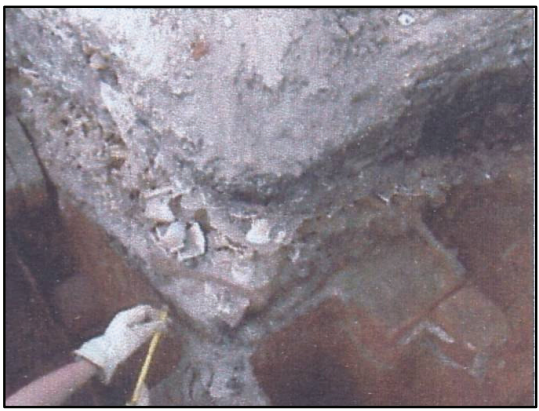




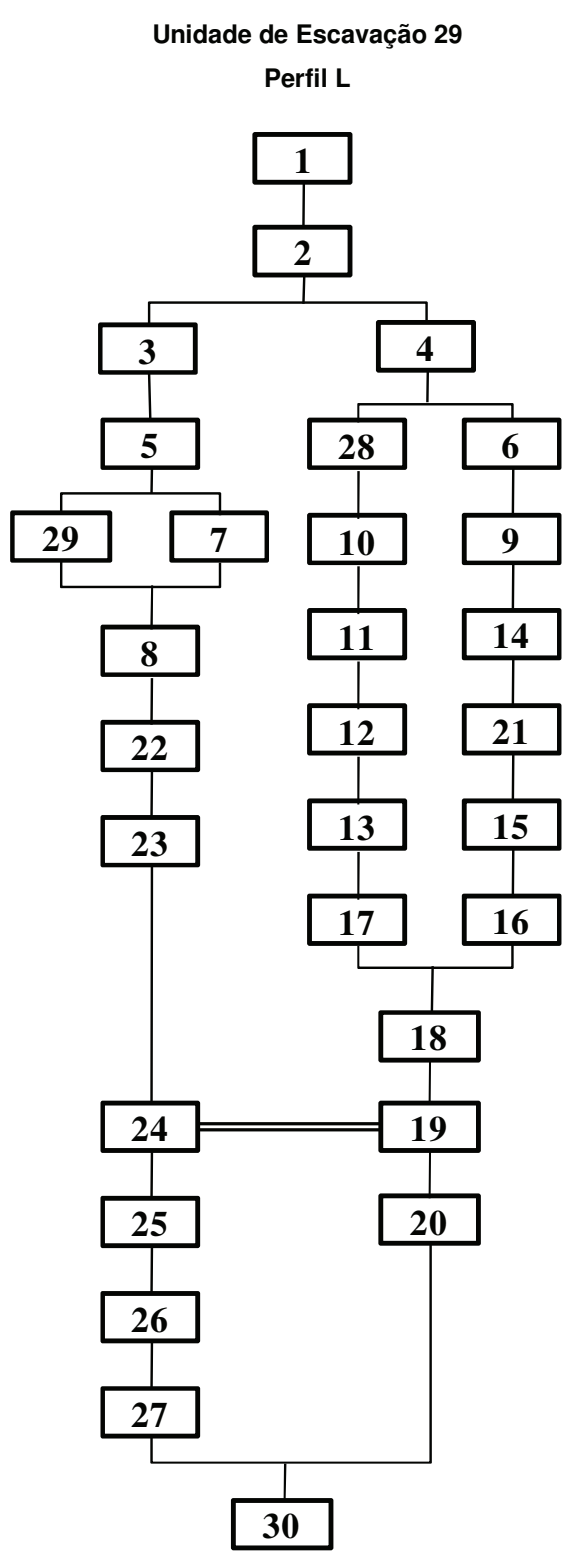

1. Aterro: sedimento areno-argiloso, compactado, cor avermelhada

2. Piso de concreto

3. Aterro: sedimento areno-argiloso, compactado, cor avermelhada

4. Aterro: sedimento areno-argiloso, compactado, cor marrom escura

5. Aterro: entulho construtivo (cimentos e tijolos maciços)

6. Aterro: entulho construtivo (cimentos e tijolos maciços)

7. Embasamento de tijolos maciços

8. Piso de concreto

9. Embasamento de tijolos maciços

10. Aterro: sedimento areno-argiloso, compactado, cor marrom escura

11. Aterro: sedimento areno-argiloso, compactado, cor avermelhada

12. Aterro: sedimento areno-argiloso, cor amarelada com inclusões de fragmentos de louças moídas

13. Aterro: sedimento areno-argiloso, compactado, cor marrom escura

14. Aterro: sedimento areno-argiloso, compactado, cor marrom escura com inclusões de fragmentos de louças e formas refratárias

15. Aterro: sedimento areno-argiloso, compactado, cor marrom escura

16. Aterro: sedimento areno-argiloso, compactado, cor avermelhada

17. Aterro: sedimento areno-argiloso, compactado, cor avermelhada

18. Aterro: sedimento areno-argiloso, compactado, cor marrom escura com manchas de sedimento marrom

19. Aterro: sedimento areno-argiloso, cor marrom escurso com inclusões de grandes fragmentos de quartzo e louça moída

20. Aterro: sedimento areno-argiloso, compactado, cor marrom

21. Embasamento de tijolos maciços

22. Aterro: sedimento areno-argiloso, cor azincentada com manchas de sedimento amarelado

23. Aterro: sedimento areno-argiloso, compactado, cor marrom escura

24. Aterro: sedimento areno-argiloso, cor marrom escura com inclusão de fragmentos de louça moída

25. Caulim

26. Aterro: sedimento areno-argiloso, cor marrom clara, com inclusão de fragmentos de louça

27. Aterro: sedimento areno-argiloso, compactado, com avermelhada

28. Bolsão de louças bem preservado (louças encaixadas, no biscoito)

29. Embasamento de tijolos maciços

30. Nível do lencol freático

Posto isto, gostaria de chamar atenção para um aspecto da composição dos estratos dos sítios históricos, e do sítio Petybon em particular, bastante recorrentes como se pode perceber pela descrição dos perfis acima, sobre o que poucos se debruçaram: aterros. A interpretação de aterros, em Arqueologia Histórica, é importante porque numerosos sítios arqueológicos aparecem no interior de cidades (ORSER 1992: 87). Ressalto-os não apenas porque a estratigrafia dos sítios históricos é composta por aterros sucessivos, mas também 
porque o sítio Petybon é, antes de tudo, um grande aterro. Para Villagrán (2008: 20) "artefatos e sedimentos estruturam conjuntamente os depósitos arqueológicos e não podem ser considerados separadamente no estudo dos processos de formação". Assim, antes de analisar as cerâmicas que compõe este aterro, é preciso mostrar o aterro em si, o aterro enquanto um artefato tendo em vista a realização de uma leitura arqueológica para os estudos destes restos humanos que nunca se encaixam confortavelmente nas definições tradicionais de "sítio" (ASHMORE \& KNAPP 1999: 2). No clássico dos anos 1960 da arqueologia estadunidense In small things forgotten, Deetz (1996: 22) propõe que uma das maiores diferenças entre os sítios históricos e pré-históricos concernia na maneira na qual grandes quantidades de aterro ("a mixture of soil and refuse") foram deslocados durante o período histórico. Para os EUA, a tendência cresceu a partir do século XVII, como pode perceber pelos projetos de aterramentos, construídos de refugos, para servirem de bases a edificações, deslocados de outros lugares.

Para Deetz (1996: 22), uma vez que estes depósitos contêm invariavelmente artefatos, eles podem ser extremamente enganosos, dado que o não reconhecimento de que o material é parte de um aterro levaria o pesquisador a incorrer em inferências errôneas sobre o sítio. Acredito, também, que considerar o material de aterro "fora de contexto" é tão sem sentido como analisá-lo como in situ "original". Primeiramente porque o material dos aterros está num novo contexto (SCHIFFER 1972; 1976), depois porque pressupor que existe algum material que se encontra em seu local de descarte "original", sem sofrer qualquer efeito de processos pós-deposicionais, tanto culturais como naturais, é cair no que Araújo (1995: 4) chamou de "noção errônea e (perigosamente) implícita de que o material arqueológico encontrado em uma escavação se mostra espacialmente disposto da mesma maneira em que foi deixado pela comunidade humana que o utilizou".

Segundo Oliveira (2005: 151), as intervenções arqueológicas "têm focado seus objetivos em recolher vestígios móveis, como: louças, cerâmicas, vidros, metais, restos de alimentação, etc. Geralmente isto ocorre em detrimento de análises estratigráficas que levem em conta a transformação do terreno e estruturas relacionadas à rede de infra-estrutura da cidade". Visto a estratigrafia ser também um documento e não um mero arquivo no qual se inserem os artefatos (LUCENA 1992: 87), sigo a proposta de James Deetz quando diz: "Fill is an artifact itself, and intelligent study of it can be most instructive. This is particularly true in excavation carried out in high-density urban areas where the same soil may have been removed, shifted, and redeposited many times" (DEETZ 1996: 23). Para Harris (1979: 41), a 
unidade de estratificação é um artefato e como artefato deve ser tratado como um todo, com porções de materiais relativamente homogêneas e indivisíveis (CARANDINI 1991: 72). É a relação da parte com o todo. As faianças finas só têm sentido como parte de um todo (SOUTH 1979: 214), que é o aterro. Juntas, desempenham esta função, enquanto "material construtivo" e não enquanto "serviço de mesa": o solo, o sedimento, dentro da qual escavamos é, ele próprio, um artefato, com muitas informações a revelar (SCHIFFER 1983: 690).

Se o aterro é artefato, representando a história de vida do sítio, deve ser pensado também em termos de sua rápida formação, massiva e singular mais do que gradual ou por meio de uma série lenta de eventos cumulativos. Para os aterros do Petybon, o tempo da cidade, rápido, cosmopolita, imperou na formação dos estratos (MROZOWSKI, ZIESING \& BEAUDRY 1996: 28), mais do que num aterro formado pelo descarte fortuito de lixo à beira de um rio durante algum tempo e muito mais se levarmos em conta estratos geológicos. Aderir a estes pressupostos, em um estudo de Arqueologia Urbana, acarreta reconhecer que a) se o aterro é um artefato, o que é este artefato, como é produzido, quais as possibilidades de sua produção, como dialoga com a formação do registro arqueológico, ou melhor, registro arqueossedimentar (VILLAGRÁN 2008: 21); e b) se o artefato arqueológico é um ente ativo dos aspectos culturais de uma sociedade (SCHIFFER 1983: 676), além do funcional, há então aspectos simbólicos nos usos e na produção dos aterros?

Deste modo, análises de aterros de sítios arqueológicos são fundamentais para o entendimento da dinâmica das transformações do espaço urbano e da formação da paisagem urbana atual, além da óbvia importância de seu papel junto à compreensão da existência e conservação dos vestígios arqueológicos (OLIVEIRA 2005: 152). Charles Orser define os aterros como camadas de terraplenagem, compostos por depósitos de areia, pedra, cascalho e artefatos que são, intencionalmente, usados em alguns projetos de construção (ORSER 1992: 86). "Os aterros são evidências da ação do ser humano no ambiente. Apesar de apresentar grande complexidade e dificuldade de exame, procurar identificar a origem dos sedimentos, porquê, por quem, como e quando foi feito, auxilia na compreensão do espaço e apresenta elementos que influenciam na avaliação do potencial arqueológico da região" (OLIVEIRA 2005: 152). Daí que para além de uma unidade estratigráfica, o aterro deve ser entendido como "unidade de ação", para que se torne inteligível (CARANDINI 1991: 134); a estratificação como, portanto, uma seqüência de ações e atividades humanas e naturais acumuladas (CARANDINI 1991: 15). 
Segundo o Houaiss (2001: 333), a palavra portuguesa aterro é citada pela primeira vez em 1831, designando "ato ou efeito de aterrar... um lugar que se elevou ou nivelou com terra ou entulho; aterrado... obra que consiste na deposição de terra ou de material granuloso solto sobre um terreno natural, para formar um chão ou base firme, nivelado ou alteado; aterramento... entulho com que se enche um fosso ou depressão de terreno, ou com que se nivela ou eleva um local". Já aterrar, além do significado (do século XV) de "encher ou cobrir com terra", tem a significação antiga (do século XIII) de "derrubar", depois, "meter medo, assustar", ou, ainda, "atirar por terra". Etimologicamente, o objeto, aterro, e a ação, aterrar, guardam dois sentidos: o de uma modificação antrópica sobre uma paisagem ou ambiente natural, criando camadas de terra e artefatos, e o de derrubar, verbo transitivo: quem derruba, derruba algo com algum intuito.

As escavações do sítio Petybon, e o estudo de suas unidades estratigráficas possibilitaram diagnosticar a existência de quatro tipos de aterro (com algumas variantes), os quais classificaria do seguinte modo:

\begin{tabular}{|c|c|c|}
\hline $\begin{array}{l}\text { Tipo de } \\
\text { aterro }\end{array}$ & Descrição & Variantes \\
\hline 1 & $\begin{array}{l}\text { Quando o aterro forma-se ao longo de um } \\
\text { intervalo de tempo devido ao descarte } \\
\text { gradual de lixo num determinado local }\end{array}$ & \\
\hline \multirow[t]{3}{*}{2} & \multirow[t]{3}{*}{ Quando se aterra com sedimento deslocado } & $\begin{array}{l}\text { Sem a presença de vestígios móveis como } \\
\text { cerâmicas, vidros, etc. Ou seja, só há presença } \\
\text { de sedimento. }\end{array}$ \\
\hline & & $\begin{array}{l}\text { Com a presença de vestígios móveis trazidos } \\
\text { junto do sedimento (ou seja, pegou-se terra de } \\
\text { uma lixeira, um local de descarte ou um aterro } \\
\text { já conformado). }\end{array}$ \\
\hline & & $\begin{array}{l}\text { Com a presença de artefatos presentes no aterro, } \\
\text { descartados no momento do aterramento. }\end{array}$ \\
\hline \multirow[t]{2}{*}{3} & \multirow{2}{*}{$\begin{array}{l}\text { Quando o sedimento é do próprio terreno } \\
\text { que contém o aterro, mas que por causa de } \\
\text { obras ou outra ação foi remexido e então } \\
\text { reposto no local como aterro (quando, por } \\
\text { exemplo, ocorre terraplenagem). }\end{array}$} & $\begin{array}{l}\text { Sem a presença de vestígios móveis como } \\
\text { cerâmicas, vidros, etc. Ou seja, só há presença } \\
\text { de sedimento. }\end{array}$ \\
\hline & & $\begin{array}{l}\text { Com a presença de artefatos presentes no aterro, } \\
\text { descartados no momento do aterramento. }\end{array}$ \\
\hline \multirow[t]{2}{*}{4} & \multirow[t]{2}{*}{$\begin{array}{l}\text { Quando o aterro é formado apenas por } \\
\text { artefatos depositados no solo. }\end{array}$} & $\begin{array}{l}\text { Com a presença de artefatos descartados } \\
\text { durante o processo de aterramento }\end{array}$ \\
\hline & & $\begin{array}{l}\text { Com a presença apenas dos artefatos } \\
\text { depositados para o aterro, sem materiais } \\
\text { teoricamente que não teriam a ver com o } \\
\text { material do aterro (ou seja, sem a presença de } \\
\text { artefatos descartados no momento do } \\
\text { aterramento). }\end{array}$ \\
\hline
\end{tabular}


No caso do sítio, há predomínio dos tipos 1,3 e 4. Isto é: para a construção das edificações, foi necessário o nivelamento do terreno com a formação de um aterro com sedimento vermelho, areno-argiloso, substrato para os embasamentos das construções. Para os estudos dos solos urbanos antropogênicos, o aterro de tipo 1 se encaixaria no que é descrito como man-influenced soil (LEHMANN \& STAHR 2007: 249). Não preciso lembrar que áreas inclinadas tendem a ser alteradas, mais propícias a presença de aterros ou escavações, por vezes combinados, para a eliminação das diferenças do terreno (OLIVEIRA 2005: 163), e que aterros são, por definição, compactados (RATHJE 1991: 122).

Mas os aterros do Petybon tiveram também outras funcionalidades: altear o terreno e diminuir a umidade do mesmo (tendo em vista sua localização ainda nos terraços fluviais do rio Tietê e a superficialidade do lençol freático, além da presença de dois córregos - um dentro do terreno, outro a apenas uma quadra - caracterizando o solo como quase encharcado e propício a enchentes) e agir como um dos planos das estratégias de descarte dos resíduos gerados pela produção de louça. É claro que algumas das características do terreno têm a ver com a escolha do local para a instalação da Fábrica. Ferrovias e indústrias ocuparam as zonas de transição entre planícies aluviais e colinas suaves, áreas baixas e mal drenadas, o que mostra, segundo Ab'Sáber (2007: 103), que "a grande maioria dos bairros industriais e operários justapõe-se aos terraços e planícies aluviais do Tietê e alguns de seus afluentes". Além de conformarem terrenos mais baratos, justamente pelas enchentes, e próximos à ferrovias, a proximidade de alguns cursos d'água foi igualmente imprescindível para este contexto, uma vez que "a água é um recurso fundamental na fabricação de cerâmica utilizada na homogeneização da massa, na limpeza da indústria e higiene dos ceramistas" (SOUZA 2003: 39). Por isso, também, a existência de um poço no terreno, descoberto durante as escavações.

Aqui, darei foco aos aterros dos tipos 3 e 4 (na UE 29 correspondem às camadas 26 e 28 da matriz Harris, por exemplo) por neles estarem contidas as louças da Fábrica Santa Catharina. Segundo Lehmann e Stahr (2007: 249), poderiam ser classificados como manmade soils ("artefacts comprise artefacts solely or mainly from anthropogenic material"). $\mathrm{O}$ estudo dos solos urbanos tem muito a ver com os resíduos materiais produzidos pela indústria que ali se encontrava antes (BRIDGES 1991: 28). No entanto, é importante ressaltar que um aterro que não contém material arqueológico nem por isso deve ser descartado, dado ser, ele mesmo, o material arqueológico, que modificou ou criou aquela paisagem. 
Deve-se saber, igualmente, a data do aterro e não a data de formação do sedimento ou dos objetos nele contido. Assim, por exemplo, os aterros do Petybon podem ser posteriores a 1937, apesar de algumas louças serem de 1913; já observei aterros cuja formação era de 1970, mas cujos artefatos que dele faziam parte eram do século XVIII. O pressuposto básico aqui é que o aterro é sempre cronologicamente posterior aos artefatos que o compõem (tendo em vista a vida do artefato até seu descarte) (HARRIS 1979a: 111). Com esta dinâmica de formação, no entanto, é possível que artefatos mais recentes estejam em níveis mais profundos do que artefatos mais antigos. Datar os objetos não é datar a camada.

Como ressaltei, no sítio Petybon os aterros com louças em faiança fina são basicamente dos tipos 3 e 4 . O interessante são as intenções envolvidas na formação destes dois tipos de aterro, que acabaram influenciando em minha análise cerâmica, uma vez que destas diferentes camadas resultaram louças fragmentadas ou louças inteiras, as primeiras em sua maioria já finalizadas, com vidrado, e as segundas, no biscoito. Este comportamento foi observado nas zonas de médio e alto potencial arqueológico, que, devo lembrar, sobrepõemse, nas plantas da Fábrica, a parte do terreno sem edificação, ou seja, ao quintal, área tradicional de descarte de resíduos em fábricas de produção cerâmica.

O nível mais profundo (tipo 3), sentido Leste-Oeste, foi conformado por uma camada contínua e espessa de fragmentos bastante diminutos, decorados e vidrados; já nas camadas mais superficiais (tipo 4), em alguns casos situadas imediatamente abaixo de vestígios de pisos, observou-se a existência de estruturas diferenciais de refugo, pontuais, derivadas da dejeção e empilhamento do material descartado para o eventual preenchimento de valas, buracos e correção de depressões anteriores à pavimentação. Nesta última camada, as louças encontravam-se inteiras e, literalmente, encaixadas e empilhadas. Traço algumas possibilidades para os processos de formação cultural destes registros.

Quanto às camadas mais profundas, onde se encontram louças finalizadas, fragmentadas, acredito que estas são as louças que estavam em superfície quando do funcionamento da Fábrica, resultantes dos resíduos gerados pela produção. Em geral, sítios em superfície, sujeitos a pisoteio e outras ações, geram artefatos de tamanho diminuto, sem muitos remontes. É sabido que quintais de fábricas cerâmicas são zonas clássicas de descarte dos produtos não vendidos, com defeito, quebrados durante a produção, etc. Quando da expansão da própria Fábrica, assim como quando da construção da nova unidade fabril da Petybon, o próprio solo da época foi utilizado para as obras e para o aterro, e nele constavam os diminutos fragmentos de louça que, pelo menos por 24 anos, ficaram expostos no quintal - 
sofrendo os efeitos dos processos de formação no tamanho dos artefatos (SCHIFFER 1983: 679). Constituíam, portanto, refugos secundários (SCHIFFER 1976), uma vez que após a fabricação, eram imediatamente descartados por não estarem aptos para a venda por alguma razão.

Quanto à camada de aterro de louças mais superficial, foram utilizadas louças inteiras, por vezes ainda encaixadas. O que aconteceu foi o uso de louças armazenadas dentro da Fábrica, estancadas no meio do processo produtivo (ou seja, por vezes, ainda no biscoito). Não foram, portanto, descartadas, e após um período de armazenagem (storage) (SCHIFFER \& SKIBO 1997: 38), foram utilizadas como material de aterro, onde se pode perceber a intenção de depositá-las no solo. Os encaixes, principalmente de malgas e pratos, empilhados nos setores de armazenamento, foram conservados como tal no aterro. Podemos, num primeiro momento, dizer que eram parte do refugo de fato (facto refuse) resultante de um abandono (abandonment) (o fechamento da Fábrica em 1937), dentro das possibilidades dos S-A processes estipulados por Schiffer (1976: 30). Contudo, como estas louças não sofreram uma ação de descarte propriamente dito, mas foram depositadas no solo, poder-se-ia dizer que estão dentro do que Schiffer e Skibo (1997: 39) chamaram de disposal, ou deliberate burial, para Renfrew e Bahn (2001: 47).

Mas para os itens depositados encaixados, acho que é ainda mais enriquecedor utilizar o que Binford (1978: 346) denominou positioning items (placed), uma vez que, além de estarem depositados com certo cuidado, houve um motivo assumido por trás da deposição dos artefatos no solo, antecipando um uso futuro: as louças como aterro, a alta densidade de materiais neste aterro e o encaixe das louças umas às outras, que, além do mais, acarretava o preenchimento das áreas internas dos recipientes que, como são vazadas, poderiam causar futuros acomodamentos da camada (é usual quando se constrói aterros deste tipo, que se soque a terra, ou que seja prensada, para que não existam áreas vazias que possam causar um acomodamento do sedimento ou da camada acarretando problemas estruturais caso acima dele tenha sido erguida uma edificação. Daí também a preferência, muitas vezes, de objetos fragmentados [cacos] ao invés de inteiros).

Todos estes refugos, enfim, tornaram-se parte de aterros, no processo conhecido como uso secundário (secondary use, dentro daquilo definido como $S$-S process), uma vez que estes artefatos foram, sem modificações, utilizados para uma nova função, o de material "construtivo" para aterramentos. O uso de cerâmica para aterros é bastante comum, não apenas porque ela ocupa um volume, físico, junto ao sedimento, deixando a camada de aterro 
mais espessa e compacta, mas também porque enquanto material poroso absorve umidade, agindo como elemento drenante, o que, no caso do terreno do sítio Petybon, tornava-se bastante relevante, especialmente no que diz respeito ao uso dos biscoitos da faiança fina. Além disso, estes usos são parte de estratégias para se livrar de uma enorme quantidade de lixo de uma produção cerâmica, ao que, uma das várias saídas que a Fábrica delineou, foi seu enterramento por aterramento (com eles e acima deles).

A criação de aterros com o material cerâmico pode ser visto, portanto, como uma estratégia de descarte de lixo, que, neste começo de século XX, é um ponto bastante discutido pela cidade que se urbaniza e se higieniza, com a expansão dos serviços de saneamento. Este assunto desdobra-se em três pontos: o das alternativas aos resíduos de produção cerâmica e seus impactos ambientais, o da história do lixo na cidade de São Paulo e os planos para lidar com ele, dentro da implantação das teses higienistas, e da relação que se desenvolveu, ao longo dos últimos séculos, entre lixo e aterro (com a criação, por exemplo, dos aterros sanitários).

O município de Parelhas, a $247 \mathrm{~km}$ de Natal, no Rio Grande do Norte, tem na produção de telhas sua principal atividade econômica, sendo conhecido como "a capital da telha do Seridó", onde existem cerca de 30 empresas ceramistas, que geram renda para mais de 1200 famílias através de empregos diretos. Todavia, uma realidade se faz patente: a atividade ceramista é uma das maiores responsáveis pelo processo de desertificação do Seridó. A Cerâmica Tavares, no povoado Joazeiro, por exemplo, inaugurada em 1975, produz 800 mil peças por mês, com 60 mil telhas por fornada, através da queima em fornos caeiras (abertos) utilizando a madeira da caatinga. Nesta produção, havia $10 \%$ de perda e $15 \%$ das telhas eram de $1^{\mathrm{a}}$ qualidade. Atualmente, adotaram-se novos fornos, os ditos fornos abóbadas e garrafões (fechados) com a utilização, enquanto lenha, de pó de madeira, casca de côco, restos de serraria, etc., fazendo com que a perda por fornada caísse para apenas 3\%. Essa mudança teve em vista os impactos causados pela produção cerâmica, o desmatamento da caatinga, a elevada produção de gás carbônico pela queima e os problemas acarretados com os resíduos gerados pela produção: se $10 \%$ das telhas da fornada eram descartadas, então, por fornada, 6 mil telhas não estavam aptas à venda. Quanto refugo e lixo não seriam gerados em um ano!?

Em Ituiutaba, Minas Gerais, um estudo sobre avaliação de resíduos cerâmicos também da fabricação de telhas mostrou que a produção cerâmica na cidade gerava 407 toneladas de cacos por mês. Estes cacos são resultantes de quebras na produção, geradas por 
telhas inteiras que não apresentaram, pós-queima, características exigidas para comercialização, ou gerados por quebras das telhas devido à movimentação a que são submetidas no universo fabril (DIAS 2004: 37). Avaliando o uso de agregados reciclados de telhas de cerâmica vermelha em camadas de pavimentos de baixo volume de tráfego, percebeu-se que, para a produção de outro município mineiro próximo, Monte Carmelo, onde as fábricas de telha geram 1,9 kg/hab.dia, seria possível executar 10,8 km de camada base de pavimento por ano, ou $32 \mathrm{~km}$ ao se misturar 40\% de solo (DIAS 2004).

Por fim, a Porcelana Monte Sião, também em Minas, com um forno em funcionamento, produz, por fornada, 35 mil peças. Destas, aproximadamente $10 \%$ saem sem possibilidades de comercialização, ou seja, 3.500 peças. Se a Porcelana realiza duas queimas por mês, então são 7 mil peças não vendidas, que se tornarão refugo e resíduo industrial. Em um ano, assim, são 84 mil peças descartadas!

Utilizei estes exemplos para mostrar, primeiramente, que apesar do sítio Petybon parecer um enorme sítio, em quantidade de peças, ao ser comparado com sítios históricos de unidades domésticas, ao que estamos acostumados, não nos chocaria se fosse comparado a sítios de produção, como olarias e fábricas (pouquíssimo escavados). Em comparação a lixeira de uma casa, é claro, o sítio Petybon é gigantesco, mas comparado com a quantidade de refugo gerado por uma fábrica de cerâmica, são completamente plausíveis as dimensões do sítio: está de acordo com uma unidade de produção. Posso apenas imaginar a quantidade de louça descartada pela Fábrica Santa Catharina em 24 anos de produção, sendo que a iniciou com 8 fornos e na época dos Matarazzo chegou a ter 17. Se utilizarmos a mesma projeção de dados da Porcelana Monte Sião, tendo em vista 13 anos (1913 a 1926) com a presença de 8 fornos, e 10 anos, com 17 fornos (1927 a 1937, época da IRFM), pressupondo duas fornadas por mês, por forno, sendo $10 \%$ da fornada descartada, então poder-se-ia dizer que durante todo o período de existência da Fábrica, ela teria gerado cerca de 23.016 .000 de peças descartadas!!

A pergunta que fica é: para onde foi todo esse lixo? A questão dos resíduos cerâmicos hoje em dia é bastante discutida. Como reduzir os impactos ambientais gerados por estas fábricas? Existem vários exemplos, ao longo da história, de estratégias de reaproveitamento de cacos cerâmicos, seja através de usos secundários ou reciclagens. Os impactos da cerâmica em paisagem podem ser vistos, por exemplo, no Monte Testaccio, na Itália, uma pequena montanha artificial, com 50m de altura, formada, ao longo de três séculos, pelo descarte, no local, de ânforas romanas (MARTÍNEZ, RODRÍGUEZ \& ALMEIDA 1989). Muitas vezes, 
cerâmicas foram reutilizadas como elementos construtivos (SULLIVAN 1989), a citar, por exemplo, os vários cacos presentes em paredes de taipa, preenchendo cabodás, etc. As fábricas de louça do município de Pedreira, no estado de São Paulo, desde 1914, data inicial da instalação da produção na cidade, enfrentam o problema do reaproveitamento dos resíduos industriais, os cacos, resíduos sólidos não biodegradáveis, e da ausência de locais adequados de descarte, resultando no acúmulo de cacos em locais impróprios e na construção de aterros ilegais (SOUZA 2003). South (1979: 222) lembra do caso de uma olaria de stoneware em Yorktown, Virgínia, EUA, onde uma rua próxima foi toda pavimentada com restos da produção cerâmica.

Por isso acredito que a Fábrica Santa Catharina, posterior IRFM - São Paulo, desenvolveu estratégias para lidar com estes resíduos e refugos industriais, dentre os quais ressalto o uso das louças como tempero para tijolos e caixas refratárias (reciclagem) e a construção, com as louças, de um aterro (uso secundário). O aterro, portanto, também como uma solução. Não duvido, igualmente, que a Vila Romana seja, literalmente, um "bairro sobre louças", já que a Fábrica deve ter descartado seus cacos e refugos em outros terrenos próximos (até hoje muitas fábricas cerâmicas têm local de deposição clandestina de cacos, geralmente em regiões mais periféricas [DIAS 2004: 39]), utilizando-os para aterrar o córrego que cortava seu terreno - o próprio córrego do Mandy deve ter sido um local constante de descarte e quem sabe até mesmo as margens e o interior do rio Tietê (o complexo de fábricas de louça em Pedreira, por muitas décadas jogou os resíduos da indústria cerâmica no rio Jaguari, contribuindo para seu assoreamento e entupimento dos locais de escoamento das águas fluviais, favorecendo muitas enchentes no município [SOUZA 2003]).

O uso das louças como aterro dialoga também com a história do lixo e do saneamento na cidade de São Paulo, uma vez que ainda não existia um sistema de coleta e que estamos no auge das ideologias da higiene, da presença de micróbios e miasmas e de suas relações com o lixo. Foi no século XIX, com o crescimento das preocupações endêmicas, que o lixo passou a ser encarado como perigo à ordem pública e à saúde, sendo dado início a um debate mais amplo sobre saneamento na cidade (MIZIARA 2008: 4-5). Em 1893 foi protocolado o primeiro contrato com uma empresa particular, a Mirtil Deutsch e Fernando Dreyfus, de serviços de coleta domiciliar e varrição, lavagem de ruas, limpeza de bueiros e bocas de lobo, incineração de lixo e limpeza de mercados. Em 1894 é criado o primeiro Código Sanitário do Estado, com mais de 500 artigos sobre procedimentos de higiene e saúde pública, regulamentando espaço público e privado, em ruas, praças, habitações, fábricas e oficinas. 
Segundo Miziara, o código criou uma geografia do lixo na cidade, afastando dos centros urbanos tudo que pudesse "depor contra os preceitos de civilidade e, conseqüentemente, de higiene" (2008: 7).

Constituíram-se espaços específicos para os restos. Longe dos centros urbanos, a Fábrica na Lapa tinha amplos espaços para jogar suas louças descartadas. É claro que o local mais fácil e viável, sem custos de transporte, era seu próprio quintal (que é o aterro do sítio Petybon). Além disso, seguindo as novas concepções de higiene, esconder o lixo enterrandoo, evitava a proliferação dos micróbios e agentes causadores de doenças. Os aterros como locais de descarte do lixo urbano só tenderam a crescer ao longo do século XX, com a criação, a partir dos anos 1950, dos aterros sanitários. Depois da II Guerra, aterros se tornam o modo mais popular de dispor os restos, mas poucos se dedicaram a pensar sobre eles, seus impactos sociais em longo termo e suas conseqüências ambientais (RATHJE, HUGHES, WILSON, TANI, ARHCER, HUNT \& JONES 1992: 444). Qual o impacto do lixo em nossas vidas e no mundo material em torno de nós? (SHANKS, PLATT \& RATHJE 2004: 71).

Este lixo dialoga, por sua vez, com os planos de urbanização e expansão da cidade. Com a instalação mais maciça de indústrias numa região, a produção de resíduos industriais começa a crescer em quantidade e a mudar em conteúdo, enquanto as atividades industriais crescem em importância (BRIDGES 1991: 28). Esta nova ocupação da cidade, com o estabelecimento de fábricas e indústrias, se relaciona à paisagem existente à época de sua instalação. Estamos na São Paulo que se urbaniza abrindo novas ruas e grandes avenidas e construindo novos edifícios, com grande predomínio da arquitetura de fábrica. Os anos 1920 marcaram o início da verticalização da ocupação da colina central; as igrejas, que durante séculos foram os marcos na paisagem, desapareceriam perante os arranha-céus (JARDIM, MUSA \& MENDES 2003: 22). Em razão dos projetos urbanos nas áreas centrais, as autoridades não faziam segredo da sua intenção de desapropriar e excluir destas áreas os núcleos de população, em especial aqueles em estado de miséria (SEVCENKO 1992: 140). Tudo isso se deu em detrimento de paisagens anteriores, modificadas pela ocupação e pelo crescente campo da construção civil. Este diálogo entre o que havia de ocupação anterior na paisagem, com o que será nela implementado, entre o antigo e o novo, o arcaico e o moderno, está no cerne das questões sobre a modernidade que se tenta implantar na cidade de São Paulo neste começo de século. Proliferam-se as obras, as construções, os aterros e as derrubadas. 
É por isso que aqui retomo a etimologia das palavras "aterro" e "aterrar". O que estava acontecendo em São Paulo não era apenas o nivelamento de terrenos ou o preenchimento de desníveis com terra e refugos materiais (uma característica mais funcional do aterro), mas a construção de novas feições da cidade, derrubando e aterrando sobre aquilo que era antigo. Os planos de urbanização mostram bem um desejo de apagar uma São Paulo com feições ainda coloniais, para o soerguimento de uma São Paulo cosmopolita, a metrópole, e para isso não apenas os hábitos considerados tradicionais estavam sendo combatidos, como também as representações materiais destas tradições. Por isso acho que o aterro teve um papel simbólico: o de sepultar o que veio antes. A idéia é que num perfil estratigráfico, o aumento da profundidade seria inversamente proporcional a cronologia dos eventos de formação (HARRIS 1975: 113), apesar disso nem sempre ser verdadeiro (ARAÚJO 1995). Percebe-se, nas matrizes de Harris, a presença de embasamentos de tijolos maciços abaixo de aterros de louça, acima dos quais novas fiadas são encontradas.

Enquanto construção de uma paisagem, o aterro como manipulação do meio seria um elo entre diferentes ocupações e, também, "uma forma de uma dada população humana interagir com os produtores de ocupações humanas anteriores - sofrer influências destas, intervir em seus vestígios, tecer considerações sobre elas" (HORTA 2004: 56). A expressão do que é considerado moderno teria, no aterro, literalmente, sua linha divisória, pois o que está abaixo da terra é o antigo, o tradicional, o colonial, o que se quer fazer sumir. Derrubar não basta, há que se aterrar: o uso prático dos significantes "aterro" e "aterrar". A Santa Catharina aterrou o terreno que comprou, desnivelado e, como se vê nas plantas históricas, já ocupado por uma pequena edificação, que deve ter sido derrubada; a Fábrica Petybon, reformando a Santa Catharina, usou suas louças para aterrar não apenas o terreno, como algumas antigas construções, derrubadas. A Mofarrej, por sua vez, derrubou todo o complexo, terraplenou e criou nova camada de aterro. Esta última, apagando as antigas feições do bairro operário e fabril, com o erguimento de um condomínio residencial.

Mas o aterro também tem outra dimensão de sua expressão simbólica, dentro da dinâmica da relação homem-natureza. Se nesse início de século, da belle époque, é a metrópole moderna que se quer firmar, ela se faz em detrimento da natureza, com marcas cada vez mais apagadas na cidade. A cidade, assim, aparece como um conjunto intensamente inter-relacionado de ações humanas que exclui, ou tenta excluir, fundamentalmente o predomínio da natureza dentro de seus limites. As estruturas construídas pelo homem fossos, terraplenagens, muros - estabelecem "conjuntos estratigráficos completamente 
artificiais" (CARANDINI 1991: 40) que agem, muitas vezes, contra as ações da natureza: enchentes, chuvas, etc. Os aterros localizados às margens do Tamanduateí são exemplos do processo (DOCUMENTO ARQUEOLOGIA E ANTROPOLOGIA 2007). Não é este o caso do aterro do Petybon, uma manipulação do meio e da paisagem (a criação de uma paisagem)?

A aplicação dos aterros, no caso do sítio Petybon, é um exemplo da adaptação do meio a um sistema sociocultural e político - ou às necessidades e desejos humanos - pelos seres humanos que com ele coexistiram (BALÉE \& ERICKSON 2006: 4), assim como uma adaptação dos seres humanos a este meio. Todas estas intervenções percebidas no sítio sobre as feições naturais do terreno estão associadas às percepções dessas feições e à atribuição de significados culturais (HORTA 2004: 15). É o que a Ecologia Histórica vem chamando de “dinâmica recíproca entre sociedade e meio ambiente" (BALÉE \& ERICKSON 2006: 9). A construção da paisagem atual da Vila Romana, mais especificamente quando penso na formação do sítio Petybon, com seus aterros para a construção de uma Fábrica, são produtos da ação humana, e da intencionalidade humana (mais que o resultado de alguma força evolutiva). 


\section{CAPÍTULO 2}

\section{ATRIBUTOS, CATEGORIAS DE ANÁLISE E ARTEFATOS DO SÍTIO PETYBON}

No presente capítulo apresentarei uma explicação dos atributos considerados durante a análise das faianças finas do sítio Petybon, junto dos gráficos correspondentes ao acervo analisado. A necessidade desta explanação está no fato de que muitos dos atributos por mim elencados não são usualmente utilizados para a faiança fina, seja porque lido com uma unidade de produção e não com um refugo de unidade doméstica, onde as louças já estariam finalizadas para o consumo, seja porque o objetivo que permeia todo o trabalho é o de mostrar a originalidade da louça em faiança fina nacional, buscando atributos que a diferenciem, e facilitem seu reconhecimento, em relação à louça em faiança fina estrangeira. Como não estou partindo dos pressupostos de noções de "cópia", analisei as características das louças do sítio Petybon de modo que as afastassem das louças forâneas, apesar de saber existir semelhanças. Além disto, com o objetivo de realizar análises tecnológicas, estipulei uma ampla gama de atributos relacionados às diferentes etapas da cadeia operatória, etapas estas formadas por um gestual que, justamente, diferenciará estas louças, mesmo que, às vezes, muitas destas etapas não tenham apelo no produto final. Logo, as louças foram analisadas segundo seus atributos tecno-morfológicos e decorativos (parte da peça, etapa do processo de produção, tratamentos de superfície, processo de esmaltação, defeitos de produção, marcas, técnicas decorativas e padrões decorativos); foram igualmente analisadas as chamadas cerâmicas de olaria ou mobiliários de forno.

Importante ressaltar que, apesar da presença de outros materiais como porcelanas e vidros, foquei-me nas faianças finas e seu processo de fabricação, já que compõem quase 100\% do material resgatado no sítio Petybon.

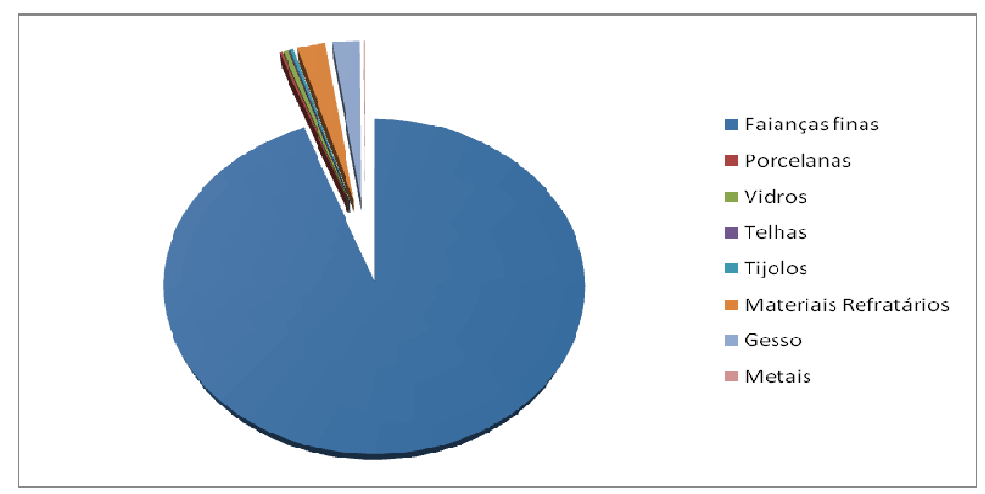


Instituí, para a análise, um recorte, tornando a amostragem a alternativa mais viável, tendo em vista as restrições de tempo (ARAÚJO 2001: 100) e a relação entre novas informações qualitativas e quantitativas. Foram analisadas as 29.740 peças resgatadas do sítio, com ficha de análise mais geral, com menos atributos, identificando morfologias, atributos decorativos, matérias-primas e etapas da cadeia operatória (biscoitos/vidrados). Por outro lado, foi, deste total, analisado de modo pormenorizado uma amostra de 1818 peças que compõem as coleções MAE, IPHAN e NAUBC, nas quais analisei aspectos como tratamentos de superfície, esmaltes, gretamentos, defeitos, decorações, digitais, etc. Importante ressaltar que na amostra estão todas as peças decoradas provenientes do sítio.

\section{Faianças Finas}

Chamo o material estudado aqui de "louça" e de "faiança fina" por serem termos já consagrados, ao menos em Arqueologia Brasileira, o que não faz, de modo algum, a faiança fina ser menos "cerâmica". "Louça" não passa de uma designação genérica para "todo produto manufaturado de cerâmica, composto de substâncias minerais sujeitas a uma ou mais queimas" (PILEGGI 1958: 194-195). Em análises de materiais de sítios históricos, a separação entre peças de "cerâmica" e peças em "faiança fina" é meramente didática e reflete a falta de uma terminologia mais específica, já que a faiança fina é, afinal, uma cerâmica; serve, então, apenas para diferenciar as peças feitas de modo menos industrializado com coloração mais avermelha e mais grosseiras (burdas em espanhol ou coarse em inglês) daquelas de pasta muito branca com granulometria fina e vidrado (fina em espanhol ou refined em inglês). Adoto a classificação de Zanettini (1986: 122), segundo o qual "os produtos em faiança fina apresentam pasta dura e opaca branca, infusível ao fogo de porcelana (...). Sua pasta é produto de vários ingredientes, conforme a fábrica que os aplica; é compacta e de forma geral esbranquiçada dispensando o engobo". Esta pasta, necessariamente, deve ter mais de $30 \%$ de caulim, para que não ocorram formulações excessivamente fundentes, e menos de $70 \%$, para não permitir a formulação de massas refratárias (SILVA, SOUZA, SILVA \& HOTZA 2009: 28). Invenção inglesa do século XVIII, "representa o esforço dos oleiros ingleses na busca de novos processos para substituir a faiança clássica e alcançar a porcelana no Ocidente" (BRANCANTE 1981: 129). Para 
Pileggi (1958: 195), a faiança fina é uma categoria intermediária entre a faiança e a porcelana, descoberta durante a manipulação do grès (BRANCANTE 1981: 129).

Não obstante, existem outras nomenclaturas para a faiança fina que são, em verdade, variedades pontuais da fabricação da pasta básica de argila, caulim, feldspato e quartzo. Póde-pedra, por exemplo, é uma nomenclatura bastante utilizada entre os ceramistas. O Sindicato da Indústria da Cerâmica de Louça de Pó de Pedra, da Porcelana e da Louça de Barro no Estado de São Paulo, por exemplo, adotou o nome seguindo a justificativa de que deveria haver um termo patenteado brasileiro para uma pasta já fabricada em outros países. O governo brasileiro exigiu patente para sua fabricação, na qual era preciso constar uma denominação específica ao novo material empregado (PILEGGI 1958: 195). A origem do termo estaria no aspecto da pasta, resultante da moagem do feldspato e do quartzo a pó não muito fino, no qual as partículas a que ficam reduzidos, visíveis e desiguais em tamanho, dariam a impressão de um "pó de pedra" (ZANETTINI 1986: 123).

O mesmo ocorre com o termo "granito". Para Brancante, a louça granito se diferencia da pó-de-pedra por ter uma pasta mais fundente, mais resistente e com menos capacidade de absorção, ou seja, menor permeabilidade, aproximando-se, por isso, da porcelana (BRANCANTE 1981: 513). Existiria também uma diferenciação segundo a temperatura de cocção, apesar de uma semelhança na composição da massa e no processo de fabricação, dado que a louça pó-de-pedra seria cozida a $1150^{\circ} \mathrm{C}$, mais porosas e com estrutura mais granulosa, e a granito entre $1250^{\circ}$ e $1300^{\circ}$, menos absorventes e, aparentemente, menos granulosa (MEMORIAL DO SINDILOUÇA: 4). Para Miller (1991) uma das designações de ironstone seria granito, ou seja, poderíamos relacionar a "louça granito", com base no autor, à porcelana brasileira. Segundo o Almanak Laemmerte de 1928, a Fábrica de Louças Santa Catharina (Fagundes, Ranzini \& Cia.) produzia "louça de granito" (1928: 291). Devido a esta falta de clareza e a falta de dados empíricos e fotográficos mostrando a diferença "estética" entre a granito e a pó-de-pedra, prefiro adotar o genérico "faiança fina".

É interessante, ainda, situar a faiança fina dentro do mundo dos produtos cerâmicos. Deve-se lembrar que faiança fina e faiança são artefatos diferenciados, do ponto de vista arqueológico. A faiança fina não é uma subcategoria da faiança, destarte a semelhança no nome. O termo tem relação com a língua portuguesa e, portanto, também é bastante devedor da maneira como nós encaramos o mundo cerâmico. Brancante (1981: 129) não inclui a faiança fina na categoria da faiança, segundo ele, "porque sua designação é imprópria e não corresponde ao conceito da faiança verdadeira". 
Em algumas classificações americanas, o correspondente à faiança fina seria refined earthenwares. Existiria um grupo, assim, de cerâmicas ditas earthenwares, dividido em refined earthenwares e coarses earthenwares (ROBERTS 2005): no primeiro estariam o grès, a porcelana e a nossa faiança fina, enquanto que no segundo estariam a cerâmica vidrada e a faiança ibérica. Neste esquema, a faiança fina está muito mais próxima da porcelana do que da faiança. Arqueologicamente, não existiria uma "faiança willow", como já vi em alguns trabalhos, porque este é um padrão decorativo que aparece somente em faiança finas. Na classificação citada, após a diferenciação entre refined e coarse, as faianças finas são analisadas segundo vidrados (cream, pearl ou white) ou segundo padrões e técnicas decorativas.

Existe ainda uma classificação inglesa baseada na permeabilidade das pastas, dividindo-as em impermeáveis/não porosas, nas quais se encontram a porcelana, bone-china, louças vitrificadas e grès, e os permeáveis/porosos, onde estão a terracota, a mayólica, a faiança, a faiança fina, a louça refratária e as chamadas louças de barro (PILEGGI 1958: 109). Enfim, dependendo do atributo da peça a ser ressaltado (um "atributo guia", por assim dizer), haverá variações na classificação, e artefatos, às vezes, tidos como distantes podem ser aproximados. Problema semelhante ocorre nas classificações de grés e porcelana, onde ora o grés é um tipo de porcelana ora vice-versa, e ainda conta-se com termos como "grès porcelanato", pastas como da louça sanitária e porcelana elétrica.

\section{A) $\underline{\text { Classe }}$}

Com fins de facilitar a análise, a primeira triagem das louças do sítio Petybon foi feita com base nas partes das peças passíveis de reconhecimento, isto é, criaram-se divisões relacionadas à identificação da parte da peça que forma o vasilhame, presente no registro, estipulando, a partir disso, categorias funcionais e tipos. Deste modo, foram criados três universos, caracterizados a seguir:

-Universo 1: compreende 13.418 fragmentos, sendo composto por peças fragmentadas que não possibilitaram o reconhecimento das características morfológicas ou funcionais das mesmas. Essas peças foram classificadas na ficha com os seguintes códigos:

1. Fragmento de parede 


$$
\begin{aligned}
& \text { 2. Fragmento de borda } \\
& \text { 3. Fragmento de base } \\
& \text { 4. }
\end{aligned}
$$

Em alguns sítios arqueológicos, especialmente aqueles com faianças finas muito fragmentadas, tento utilizar a categoria "ombro", ou seja, a parte angulosa entre a aba e o frete de pratos, pires, travessas, etc. O reconhecimento desta parte da peça possibilita a identificação de recipientes abertos planos, tal qual a classificação americana flatware. Deste modo, é possível saber, ao menos, se um determinado refugo continha mais recipientes fundos, côncavos, (hollowware) ou abertos, possibilitando inferências sobre práticas de consumo, etc. No entanto, quando o material do sítio Petybon começou a ser analisado, esta categoria, na época, não foi elencada, continuei com a mesma linha de atributos a fim de que pudesse unir todas as planilhas de análise e criar gráficos e tabelas com as mesmas variáveis.

-Universo 2: Este universo apresentou 8.781 peças. Compõe-se por peças nas quais não foi possível o reconhecimento de características morfológicas específicas, assim como suas exatas dimensões, a fim de sua classificação por tipo dentro da categoria funcional. Apesar disto, as características identificáveis permitem uma classificação quanto a sua funcionalidade, dentro dos universos de decoração, higiene pessoal e alimentação, sendo classificada segundo os códigos:

1. Malga / Tigela

2. Xícara

3. Caneca

4. Copo

5. Prato

6. Pires

7. Travessa

8. Terrina

9. Saladeira

10. Manteigueira

11. Tigela bojuda

12. Jarro
13. Bico de Bule

14. Tampa

15. Vaso para planta (cachepô)

16. Jarra

17. Vaso

18. Saboneteira

19. Penico

20. Azulejo

21. Apoiadores

22. Chuveirinho 
Não diferenciei as xícaras entre "xícaras de chá" e "xícaras de café" e preferi usar termos mais genéricos como "xícaras" ou "malgas/tigelas", porque estas terminologias, mais específicas, tendem a induzir função particular à forma sem que se tenham claras indicações de que este foi seu uso pretendido ou real (RICE 1987: 211). Isto se agrava no contexto com o qual estou lidando, de um universo produtivo onde, teoricamente, as louças nem mesmo foram consumidas.

Preferi utilizar a terminologia "malga" por já estar consagrada na Arqueologia Histórica brasileira. No entanto, tenho claro que este é um termo pouquíssimo utilizado no Brasil do século XX, aparecendo em poucas referências históricas e de quase nula compreensão oral. Por isso, acrescentei ao mesmo o termo "tigela" que, apesar de bastante genérico, é como muitas das pessoas que entrevistei designaram a forma conhecida como malga. Tendo em vista que a maior quantidade de peças do sítio Petybon são malgas/tigelas, será importante aprofundar um pouco mais nesta terminologia e na designação desta forma, algo que retornarei com maior afinco adiante na dissertação.

Como mostra o gráfico abaixo, há um claro predomínio das malgas/tigelas, seguidos das xícaras, pratos, pires e canecas na coleção analisada.

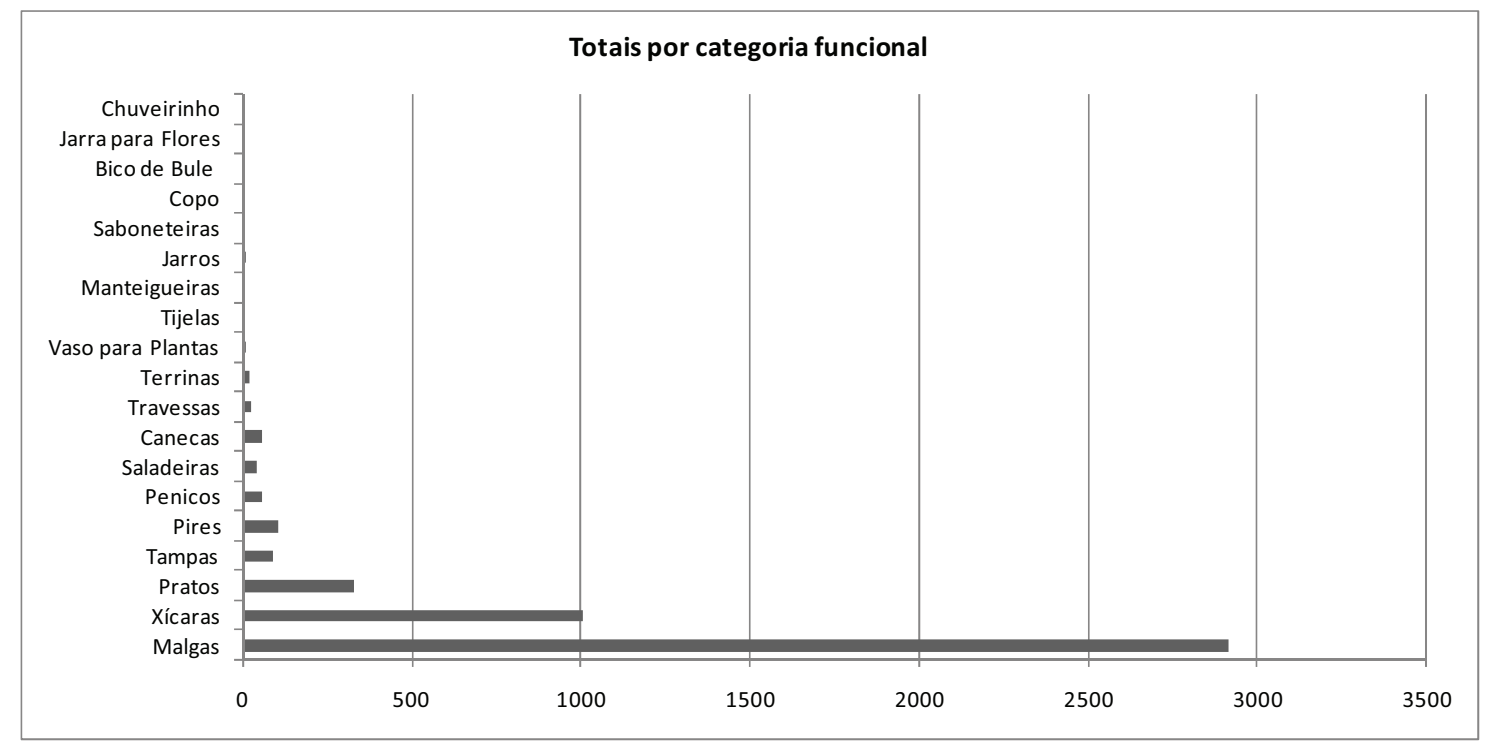

Universo 3: Composto por 3.866 peças, se caracteriza pelo universo onde as peças estão quase, ou totalmente, completas, possibilitando não apenas sua identificação do ponto de vista morfológico, como também estipular tipos, caracterizados por variações no volume e nas dimensões. Com base nestas peças, foram organizadas as 22 categorias funcionais básicas que 
comportam 104 tipos de variantes, sendo os mesmo apresentados nos quadros a seguir. Junto às medidas das dimensões dos tipos, vão os cálculos de volumes das peças. Os cálculos do volume dos vasilhames, indicando as variantes do tamanho de uma mesma forma (como as malgas/tigelas), mostram a importância da reconstituição volumétrica para o estabelecimento de classes funcionais (SINOPOLI 1992), já que pressuponho que artefatos de diferentes tamanhos e capacidades volumétricas provavelmente eram destinados a diferentes usos (GOMES 2005: 174). Formas e funções diferenciadas seriam frutos de costumes, culturas, hábitos e identidades associadas à resolução de problemas do dia-a-dia (SCHIFFER \& SKIBO 1997: 45).

\section{Malga/Tigela}

\begin{tabular}{|c|c|c|c|c|}
\hline Tipo & Base $(\mathrm{cm})$ & Boca $(\mathrm{cm})$ & Altura $(\mathrm{cm})$ & Volume $(\mathrm{ml})$ \\
\hline 1 & 3,0 & 6,0 & 4,0 & 50 \\
\hline 2 & 3,5 & 7,0 & 4,5 & 75 \\
\hline 3 & 4,0 & 8,0 & 5,5 & 125 \\
\hline 4 & 4,5 & 8,5 & 6,0 & 175 \\
\hline 5 & 5,0 & 9,0 & 6,5 & 200 \\
\hline 6 & 5,5 & 10,5 & 6,5 & 275 \\
\hline 7 & 6,5 & 11,5 & 8,0 & 400 \\
\hline 8 & $7,0-7,5$ & 13,0 & 8,5 & 550 \\
\hline 9 & $8,0-8,5$ & 14,0 & 9,5 & 625 \\
\hline 10 & 9,0 & 16,0 & 10,0 & 1000 \\
\hline 11 & 11,0 & $19,0-20,0$ & 12,0 & 2000 \\
\hline 12 & 12,0 & 22,0 & 13,0 & 2800 \\
\hline 13 & 12,5 & 24,0 & 13,5 & 3250 \\
\hline 14 & 12 & - & - & \\
\hline
\end{tabular}

\section{Xícara}

\begin{tabular}{|r|c|c|c|c|}
\hline \multicolumn{1}{|l|}{ Tipo } & Base $(\mathrm{cm})$ & Boca $(\mathrm{cm})$ & Altura $(\mathrm{cm})$ & Volume $(\mathrm{ml})$ \\
\hline 1 & $2,5-3,0$ & $4,5-5,0$ & $4,0-4,5$ & 60 \\
\hline 2 & 3,0 & $4,5-5,0$ & $4,5-5,0$ & 50 \\
\hline 3 & $3,0-3,5$ & 5,5 & 5,0 & 75 \\
\hline 4 & $3,0-3,5$ & 5,5 & 5,5 & 85 \\
\hline 5 & 3,5 & $6,5-7,0$ & 6,5 & 150 \\
\hline 6 & 5,0 & 8,0 & $5,5-6,0$ & 150 \\
\hline 7 & $4,5-5,0$ & $7,5-8,0$ & 5,0 & 200 \\
\hline 8 & 5,0 & 8,0 & 5,5 & 175 \\
\hline 9 & 4,5 & 8,0 & 7,0 & 175 \\
\hline
\end{tabular}

\section{Caneca}

\begin{tabular}{|c|l|l|l|l|}
\hline \multicolumn{1}{|l|}{ Tipo } & Base $(\mathrm{cm})$ & Boca $(\mathrm{cm})$ & Altura $(\mathrm{cm})$ & Volume \\
\hline 1 & $6,0-6,5$ & $6,0-6,5$ & $7,0-7,5$ & 125 \\
\hline 2 & $7,0-7,5$ & $7,0-7,5$ & $8,5-9,0$ & 225 \\
\hline 3 & 8,0 & 8,0 & 9,5 & 300 \\
\hline
\end{tabular}




\begin{tabular}{|l|l|l|l|l|}
\hline 4 & $5,5-6$ & $5,5-6$ & 7 & 198 \\
\hline 5 & $6,5-7$ & 7 & $8-8,5$ & 327 \\
\hline 6 & 5,2 & 5,2 & 9,5 & 202 \\
\hline
\end{tabular}

4. Copo

\begin{tabular}{|c|c|c|c|c|}
\hline Tipo & $\begin{array}{r}\text { Base } \\
(\mathrm{cm})\end{array}$ & $\begin{array}{r}\text { Boca } \\
(\mathrm{cm})\end{array}$ & $\begin{array}{r}\text { Altur } \\
\mathrm{a}(\mathrm{cm})\end{array}$ & Volu \\
me
\end{tabular}

5. Prato

\begin{tabular}{|c|l|c|c|}
\hline Tipo & \multicolumn{1}{|c|}{ Descrição } & Diâmetro da Aba (cm) & Altura (cm) \\
\hline 1 & Raso sem decoração & 21 & 2,7 \\
\hline 2 & Fundo sem decoração & 22 & 4,3 \\
\hline 3 & Raso Trigal & 22 & 2,7 \\
\hline 4 & Fundo Trigal & 21 & 3,8 \\
\hline 5 & Raso com borda ondulada & 20 & 2,7 \\
\hline 6 & Raso decorado & 23 & 2,7 \\
\hline 7 & Raso sem decoração & 22 & 2,7 \\
\hline 8 & Fundo sem decoração & 20 & 3,4 \\
\hline 9 & Fundo sem decoração & 22 & 3,7 \\
\hline 10 & Raso sem decoração & 24 & 2,7 \\
\hline 11 & Raso decorado & 22 & 1,9 \\
\hline 12 & Raso decorado & 20 & 1,9 \\
\hline 13 & Fundo decorado & 20 & 3,1 \\
\hline 14 & Prato de sobremesa & 1,7 \\
\hline 15 & Prato decorado & 20 & - \\
\hline 16 & Prato de sobremesa sem decoração & 16 & - \\
\hline 17 & Prato de sobremesa decorado & 16 & 1,4 \\
\hline
\end{tabular}

6. $\quad$ Pires

\begin{tabular}{|r|l|c|c|}
\hline \multicolumn{1}{|l|}{ Tipo } & Descrição & Diâmetro da aba $(\mathrm{cm})$ & Altura $(\mathrm{cm})$ \\
\hline 1 & - & 10,5 & 1,5 \\
\hline 2 & - & 14,0 & 2,0 \\
\hline 3 & - & 12 & 2,3 \\
\hline 4 & - & 15,5 & 2,7 \\
\hline 5 & Com lábio ondulado & 10 & 1,65 \\
\hline
\end{tabular}

7. Travessa

\begin{tabular}{|l|l|c|}
\hline Tipo & Forma & Altura $(\mathrm{cm})$ \\
\hline & Oval & 3,5 \\
\hline
\end{tabular}

\section{Terrina}

\begin{tabular}{|l|l|c|c|c|c|c|}
\hline Tipo & Descrição & Forma & Base $(\mathrm{cm})$ & Boca $(\mathrm{cm})$ & Altura $(\mathrm{cm})$ & Volume \\
\hline 1 & Trigal & Oval & $12,0 \times 18,0$ & $17,5 \times 25,0$ & 9,0 & \\
\hline
\end{tabular}




\begin{tabular}{|l|c|c|c|c|c|c|}
\hline 2 & - & Oval & $11,0 \times 16,5$ & - & - & - \\
\hline 3 & - & Oval & $15,5 \times 21,5$ & - & - & - \\
\hline 4 & Sem decoração & Oval & - & - & - & - \\
\hline
\end{tabular}

9. Saladeira

\begin{tabular}{|l|l|l|c|c|c|}
\hline Tipo & Descrição & Forma & Base $(\mathrm{cm})$ & Boca $(\mathrm{cm})$ & Altura $(\mathrm{cm})$ \\
\hline 1 & Trigal & Oval & $28,0 \times 18,5$ & $37,5 \times 28,5$ & 7,5 \\
\hline 2 & Sem decoração & Oval & - & - & - \\
\hline 3 & Sem decoração & Oval & - & - & - \\
\hline
\end{tabular}

10. Manteigueira

\begin{tabular}{|l|c|c|c|c|c|}
\hline Tipo & Forma & Base $(\mathrm{cm})$ & $\begin{array}{l}\text { Diâmetro da } \\
\text { aba }(\mathrm{cm})\end{array}$ & $\begin{array}{l}\text { Diâmetro da } \\
\text { boca }(\mathrm{cm})\end{array}$ & Altura $(\mathrm{cm})$ \\
\hline 1 & Circular & 5,5 & 12,5 & 7,5 & 4,0 \\
\hline 2 & Circular & 9,0 & - & 7,5 & 3,5 \\
\hline
\end{tabular}

11. Tigela bojuda

\begin{tabular}{|l|l|c|}
\hline Tipo & Forma & Base $(\mathrm{cm})$ \\
\hline 1 & Circular & 10,0 \\
\hline
\end{tabular}

12. Jarro

\begin{tabular}{|l|l|l|l|}
\hline Tipo & Descrição & Base $(\mathrm{cm})$ & Boca $(\mathrm{cm})$ \\
\hline 1 & - & 8,0 & - \\
\hline 2 & Sem decoração & - & 8,0 \\
\hline
\end{tabular}

\section{Bico de bule}

14. Tampa

\begin{tabular}{|l|l|l|c|c|l|}
\hline Tipo & Descrição & Forma & $\begin{array}{l}\text { Diâmetro do } \\
\text { encaixe }(\mathrm{cm})\end{array}$ & $\begin{array}{l}\text { Diâmetro } \\
\text { Total }(\mathrm{cm})\end{array}$ & $\begin{array}{l}\text { Altura } \\
(\mathrm{cm})\end{array}$ \\
\hline 1 & Tampa de açucareiro & Circular & 7,5 & 8,5 & 2,0 \\
\hline 2 & Tampa de açucareiro & Circular & 6,0 & 7,5 & 3,0 \\
\hline 3 & - & Oval & $7,3 \times 12,5$ & $9,8 \times 15,5$ & 2,0 \\
\hline 4 & Tampa de Terrina Trigal & Oval & - & - & - \\
\hline 5 & Tampa de Terrina & Oval & $12,0 \times 18,5$ & $15,0 \times 22,0$ & 2,5 \\
\hline 6 & $\begin{array}{l}\text { Tampa de Terrina com } \\
\text { encaixe para colher }\end{array}$ & Oval & $\begin{array}{l}18,0 \\
\text { (Largura) }\end{array}$ & $\begin{array}{c}21,0 \\
\text { (Largura) }\end{array}$ & 3,5 \\
\hline 7 & - & Circular & 17,0 & 20,0 & 1,5 \\
\hline 8 & - & Quadrada & - & - & \\
\hline 9 & - & Circular & 5,6 & 6,7 & 3,5 \\
\hline
\end{tabular}

15. Vaso para planta (cachepô)

\begin{tabular}{|l|l|l|l|}
\hline Forma & Base $(\mathrm{cm})$ & Boca $(\mathrm{cm})$ & Altura $(\mathrm{cm})$ \\
\hline
\end{tabular}




\begin{tabular}{|l|l|l|l|}
\hline Circular & 10,0 & 14,0 & 4,0 \\
\hline
\end{tabular}

\section{Jarra}

\begin{tabular}{|l|}
\hline Base $(\mathrm{cm})$ \\
\hline 9,0 \\
\hline
\end{tabular}

\section{Vaso}

\begin{tabular}{|r|c|c|c|}
\hline \multicolumn{1}{|l|}{ Tipo } & Base $(\mathrm{cm})$ & Boca $(\mathrm{cm})$ & Altura $(\mathrm{cm})$ \\
\hline 1 & 13,0 & 18,0 & 18,5 \\
\hline 2 & - & - & - \\
\hline
\end{tabular}

\section{Saboneteira}

\begin{tabular}{|l|l|l|l|l|l|l|l|}
\hline Tipo & Descrição & Forma & Base $(\mathrm{cm})$ & Boca $(\mathrm{cm})$ & $\begin{array}{l}\text { Altura } \\
(\mathrm{cm})\end{array}$ & $\begin{array}{l}\text { Diâmetro do } \\
\text { encaixe }(\mathrm{cm})\end{array}$ & $\begin{array}{l}\text { Altura } \\
(\mathrm{cm})\end{array}$ \\
\hline 1 & Corpo & Oval & 5,0 (Largura) & 8,0 (Largura) & 4,0 & 6,5 (Largura) & 2,0 \\
\hline 2 & Trigal & Oval & $\begin{array}{c}5,0 \\
\text { (Largura) }\end{array}$ & - & & & \\
\hline
\end{tabular}

19. Penico

\begin{tabular}{|c|l|l|c|c|}
\hline Tipo & Base $(\mathrm{cm})$ & Boca $(\mathrm{cm})$ & Altura $(\mathrm{cm})$ & Volume $(\mathrm{ml})$ \\
\hline 1 & 12,0 & 20,0 & 12,5 & 2000 \\
\hline 2 & 13,0 & 22,0 & 14,0 & 3000 \\
\hline
\end{tabular}

\section{Azulejos}

\begin{tabular}{|c|c|c|c|}
\hline \multicolumn{1}{|l|}{ Tipo } & Largura $(\mathrm{cm})$ & Comprimento $(\mathrm{cm})$ & Descrição \\
\hline 1 & 14,4 & 14,4 & - \\
\hline 2 & 7,4 & 14,6 & - \\
\hline 3 & - & 15,1 & - \\
\hline 4 & - & - & $\begin{array}{c}\text { Superfície em relevo na } \\
\text { frente e ranhuras no verso }\end{array}$ \\
\hline 5 & - & - & Com ranhuras no verso \\
\hline 6 & & & Convexas (para rodapés) \\
\hline 7 & & & Côncavos (para quinas) \\
\hline
\end{tabular}

\section{Apoiadores}

\begin{tabular}{|l|l|}
\hline 1 & Trempes \\
\hline 2 & Prisma triangular \\
\hline 3 & Cravilhos \\
\hline 4 & Com canaleta \\
\hline
\end{tabular}

22. Chuveirinho 
O gráfico abaixo mostra a quantidade de tipos por categoria funcional. Há uma maior recorrência dos recipientes de menor volume, especialmente nas categorias funcionais 1, 2 e 3, o que pode ser resultado da maior frequiência na produção de recipientes menores que, em geral, são produzidos mais rapidamente e em maior quantidade (cabem muito mais malgas pequenas nos fornos), e consumidos com maior freqüência (um recipiente por indivíduo).

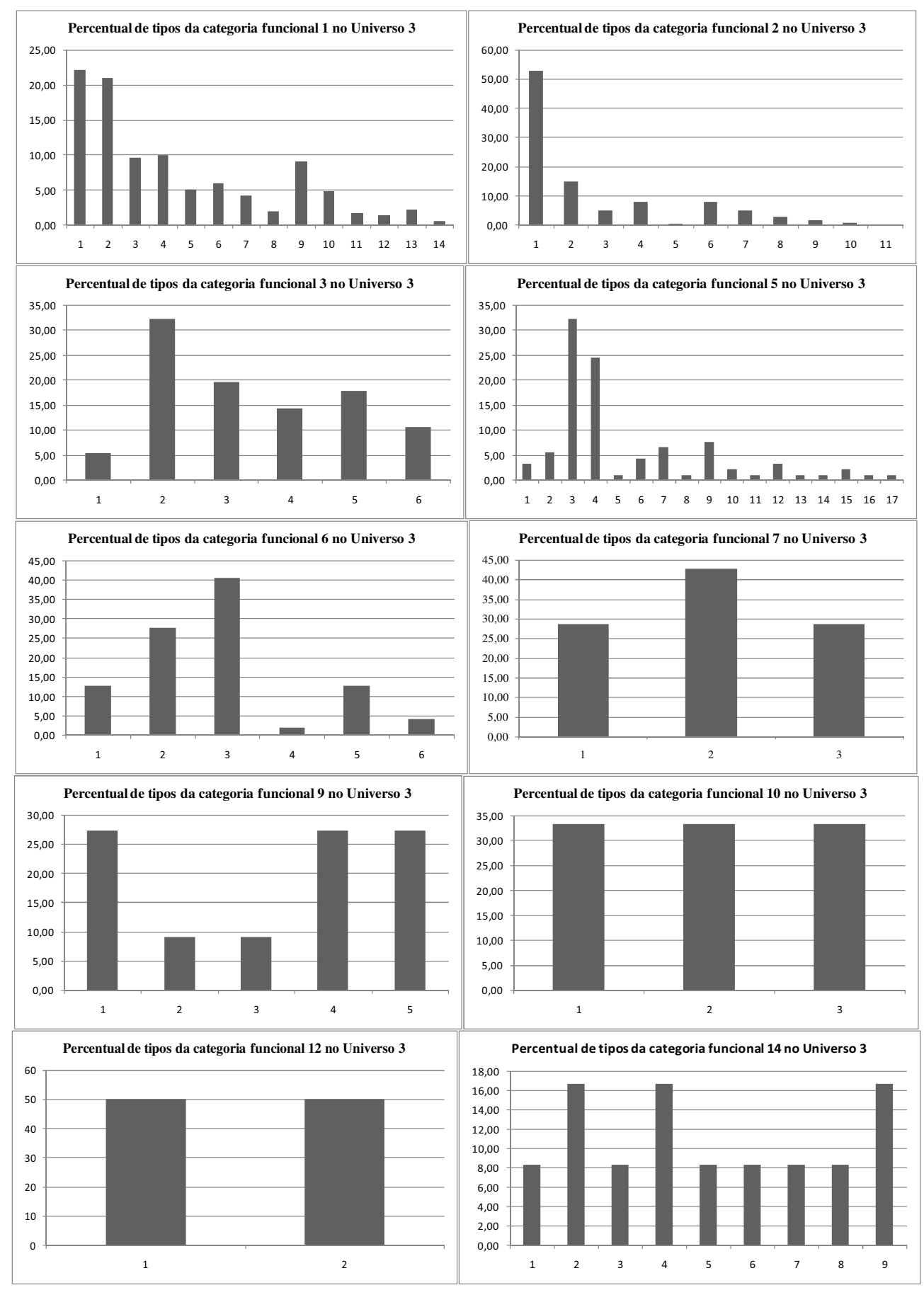




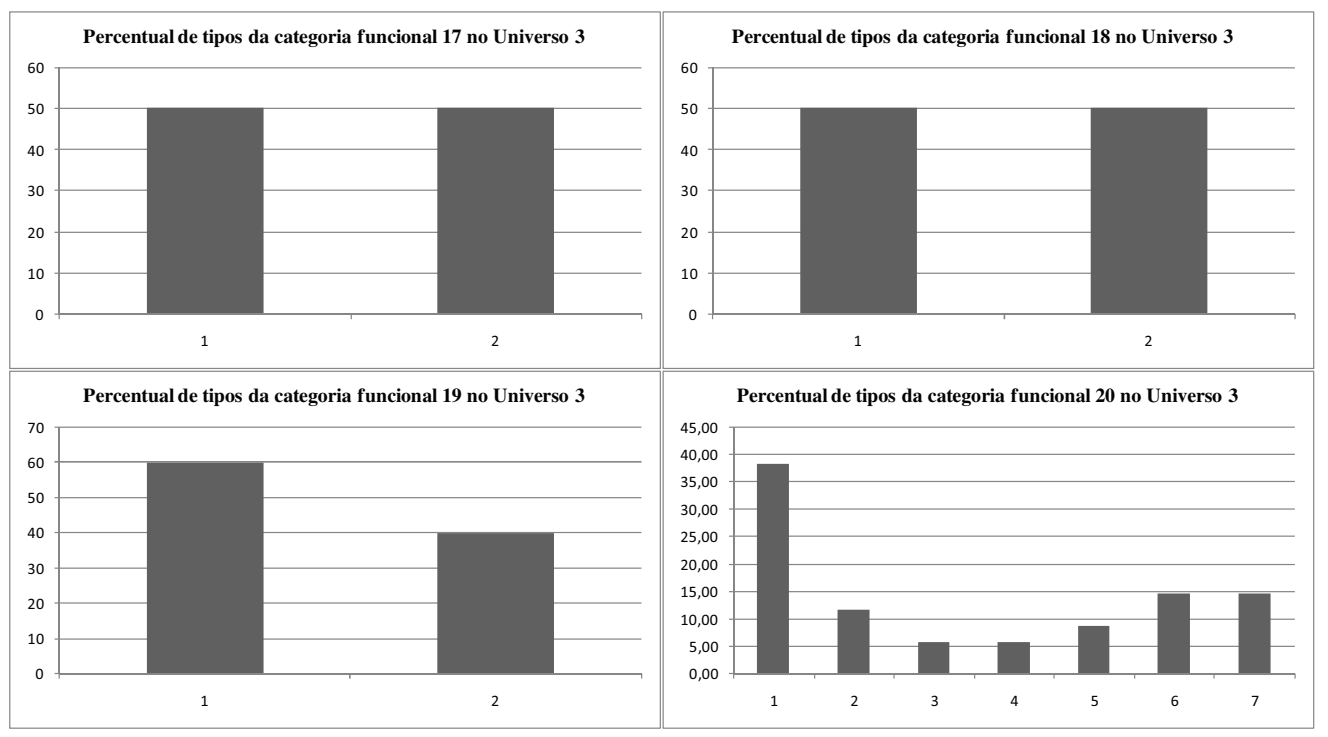



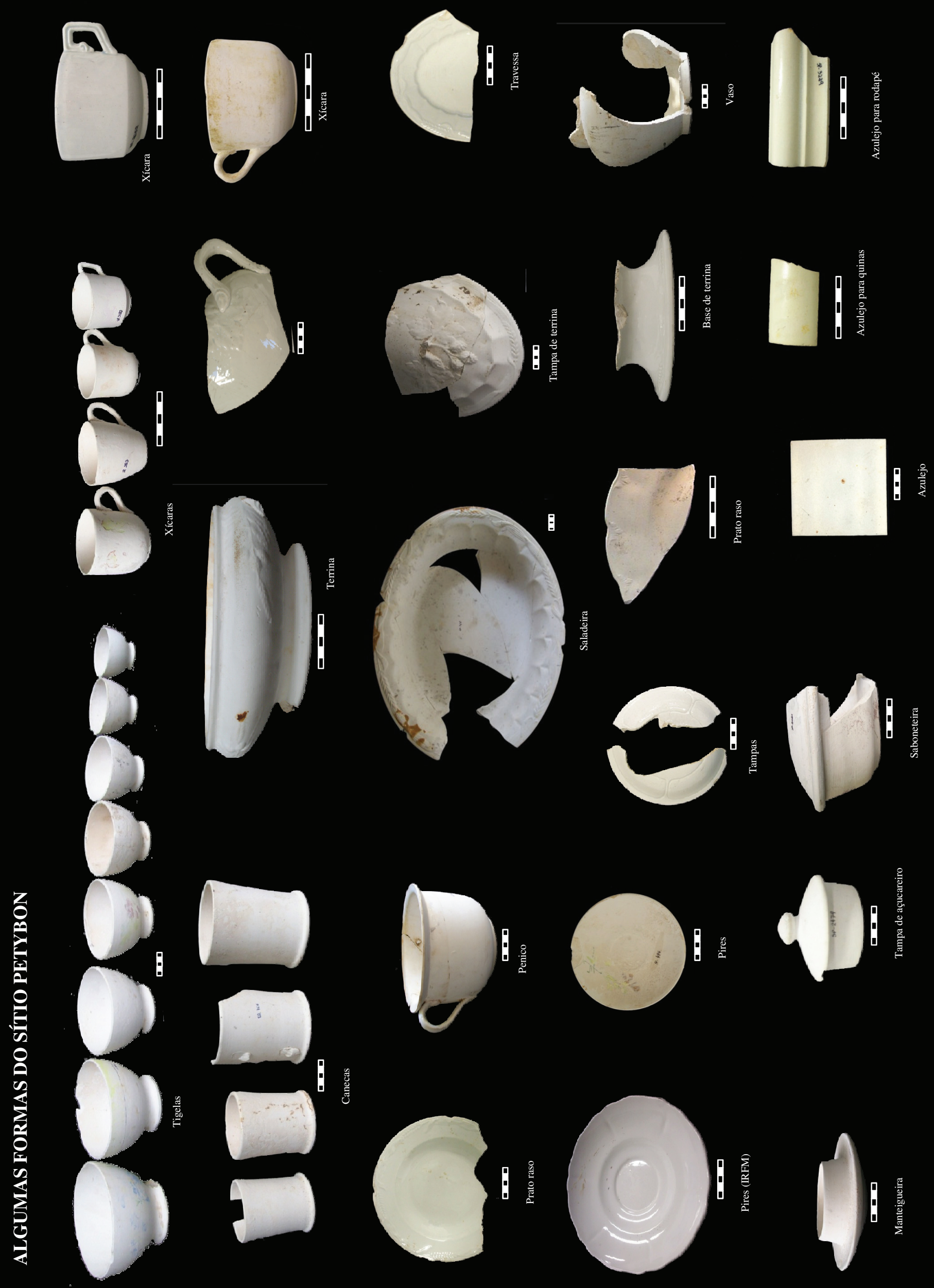


\section{B) Decoração}

O sítio Petybon contém um total de 1050 peças decoradas, tendo sido todas elas analisadas, já que as peças com decoração do sítio concentram-se majoritariamente nas coleções MAE e IPHAN. Considerei como "decoração" aquilo caracterizado como a aplicação de pigmentos que geram efeito cromático ou o que marca relevos na peça, apesar de acromáticos; neste intuito, reconheço que o "branco" também pode ser pensado como padrão e efeito decorativo, assim como uma superfície biscoitada. As peças decoradas representam apenas $4 \%$ do total do acervo gerado pelas escavações; deste total, $91 \%$ são peças com decoração em superfície modificada e $9 \%$ em superfície não modificada ou moldada. As decorações foram analisadas segundo os seguintes critérios: tipo do aspecto final da superfície do recipiente resultante do processo decorativo, técnica de produção da decoração, padrão, motivo e tema.

Como "tipo do aspecto final da superfície do recipiente resultante do processo decorativo" entendo aquilo que se classifica, para as faianças finas, como superfícies modificadas ou não modificadas (TOCCHETTO et alli 2001). As decorações em superfície não modificada foram subdivididas em decorações baixo-esmalte e sobre-esmalte, isto é, aquelas aplicadas sobre o vidrado (como a decalcomania) e aquelas aplicadas sob o vidrado, variações que implicam mudanças na cadeia e no custo dos fatores de produção.

Como técnica de produção de uma decoração, entendo "o conjunto de regras, invenções, operações e habilidades" (VARGAS 1994: 15) que convergem para a criação de uma determinada decoração ou um padrão decorativo, quando há uma repetição do motivo em diferentes peças (ARAÚJO \& CARVALHO 1993: 82). Foram identificadas, na amostra analisada, as seguintes técnicas decorativas:

- Pintado à mão livre: "aplicação da decoração de forma manual” (TOCCHETTO et alli 2001: 25), em geral com pincéis, nas quais é possível observar as marcas das cerdas e os acúmulos de tinta no contorno da pintura resultante da pressão entre o instrumento da ação e a superfície do suporte.

- Carimbado: aplicação de decoração pintada com auxílio de um carimbo (TOCCHETTO et alli 2001: 27). Em geral, por causa do instrumento (carimbo), a decoração é mais estandardizada devido à facilidade de reproduzir motivos de forma quase "idêntica" 
(menos quando o carimbo é uma esponja, como o cut-sponge), além de rapidamente. Na decoração carimbada, existe acúmulo de tinta tanto nas bordas do desenho, devido à pressão entre carimbo e suporte, como mais ao meio do mesmo, devido à força do vácuo entre o carimbo e o suporte quando o instrumento é afastado da superfície.

- Transfer-Printing: a impressão por transferência, ou transfer-printing, é um tipo de decoração impressa criada na Inglaterra em meados do século XVIII, desde cedo utilizada na faiança fina, já que concomitante à sua invenção (BRANCANTE 1981). No âmbito de seu surgimento, e até o desenvolvimento de outras técnicas ao longo do século XIX, o transfer possibilitou a criação de complexas decorações, rapidamente aplicadas às peças, certa estandardização, constituição de jogos e redução dos custos finais (SOUSA 1998: 169; TOCCHETTO et alli 2001). O processo consistia na gravação de um desenho em placas de cobre ou chapa de aço, impresso em um pedaço de filme ou papel seda, então aplicado ao biscoito. O desenho configurava um baixo relevo no metal, preenchido com tinta - quanto mais funda a incisão na placa ou quanto mais tinta, mas escuro o desenho em sua performance final (SAMFORD 1997: 3). Uma esponja, flanela ou instrumento semelhante era utilizado para remoção do papel, deixando no suporte a imagem colorida. Entre a queima, a aplicação da decoração e a queima do vidrado havia, em algumas fábricas, outra queima para fixação da decoração no biscoito e para queimar o óleo que era, em geral, misturado à tinta, para endurecê-la sobre a argila, a fim de que não houvesse risco de escorrer quando mergulhada no vidrado (DUKE 1995: 963; PYE 2007). A gama de cores dos transfers, em geral monocromáticos, era limitada devido às possibilidades de muitas mudarem ou desaparecerem completamente quando sujeitas à temperaturas muito altas, como às da queima do vidrado (DUKE 1995: 963) (além de uma preferência, a utilização do azul cobalto deveu-se a suas características em manter a cor e não desaparecer durante a queima [PYE 2007]). Com o tempo, foram simplificando-se algumas etapas, como a da construção das placas ou a transferência do desenho para o papel de seda (TOCCHETTO et alli 2001: 30).

- Esponjado: É aceite geral que o que traduzimos como "esponjado", do inglês spongeware (ou spongework), é uma metamorfose da decoração conhecida pela técnica do spatterware, desenvolvida como resultado de uma necessidade em acelerar o processo de decoração, que competiu com técnicas como o cut-sponge ou decorações aplicadas com escovas ou pedaços de pano (McCONNELL 1990: 11). Uma observação deve ser feita quanto 
ao contexto brasileiro: o de que "esponjado" é técnica, mas também cria um padrão decorativo homônimo; no entanto, seu homônimo não é o único padrão decorativo criado pela técnica padrões e motivos diferentes podem ser criados por uma mesma técnica. Cito, novamente, o exemplo da Porcelana Monte Sião, que fabrica dois tipos de "esponjado" (termo êmico) referentes às técnicas de aplicação dos pigmentos e tintas com uma esponja. Os dois padrões produzidos pela Porcelana podem ser observados abaixo.
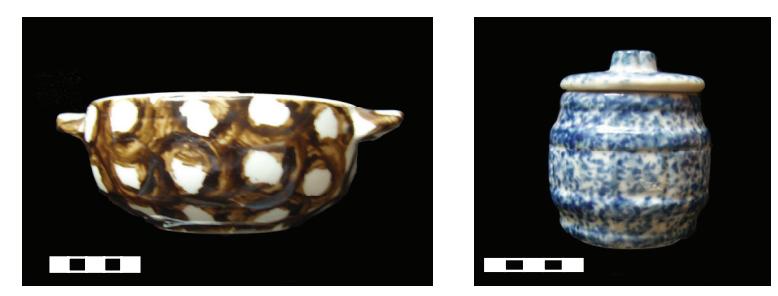

- Decalcomania: conhecida em alguns contextos como decal e como um tipo de “decoração impressa", resulta da aplicação, sobre um suporte, de motivos impressos em uma película ou papel adesivos (SOUSA 1998:197), mono e policromados. Diferente do transferprinting, com a qual é, às vezes, confundida, a decalcomania é majoritariamente utilizada em decorações sobre-esmalte, implicando, na faiança fina, em três queimas, sendo a última em forno contínuo à aproximadamente $600^{\circ} \mathrm{C}$, e apresenta um leve relevo ou aspereza. A decalcomania é produzida impressa em uma emulsão especial de papéis revestidos com película plástica. Quando pronto para usar, o plástico, no qual a decoração está aderida, é retirado e aplicado ao suporte (como um adesivo) (DUKE 1995: 953). Durante a queima, a decalcomania funde-se ao vidrado e o excesso de cola ao redor da decoração desaparece. A técnica ficou muito popular no final do século XIX, quando foi criada, mas no Brasil, a relação é indiretamente proporcional à faiança fina, isto é, quando a recorrência da técnica aumenta, as fábricas de faiança fina estão em decréscimo, ou seja, no período pós II Guerra. Daí a parceria bem sucedida da porcelana brasileira com a decalcomania, comum mesmo nos dias atuais.

- Estêncil: o estêncil é uma técnica que consiste na aplicação de um molde vazado (ou máscara) sobre a superfície do suporte, sobre o qual são aplicadas tintas, em geral através de pincéis, carretilhas ou sprays. As áreas vazadas, do molde, são, na realidade, contornos de motivos decorativos que, após aplicação dos pigmentos, ficam marcados no suporte. A técnica permite decorações mono e policromadas e uma estandardização da produção uma vez que 
reproduz motivos e padrões de modo "idêntico", de maneira rápida, sem que haja necessidade de grande domínio da técnica, como ocorre nas pinturas à mão livre.

- Moldado: as decorações moldadas são aquelas que caracterizam peças em superfície modificada. A decoração está intrinsecamente relacionada à forma da louça, uma vez que ela já está presente, em negativo, nos moldes de gesso que conformam a peça. Assim, quando a barbotina é derramada, no processo de colagem, no interior dos moldes, a massa em suspensão deposita-se nas paredes do molde e preenche os negativos, criando decorações em relevo. $\mathrm{O}$ inverso é feito quando da fabricação dos baixos relevos. Apesar de acromáticas, nas louças brasileiras existe associação entre decorações em relevo e cromáticas, com pigmentos coloridos (que caracterizam superfícies não modificadas).

- Transfer-printing associado à pintura à mão livre: associação das duas técnicas.

- Transfer-printing associado à carimbo: associação das duas técnicas.

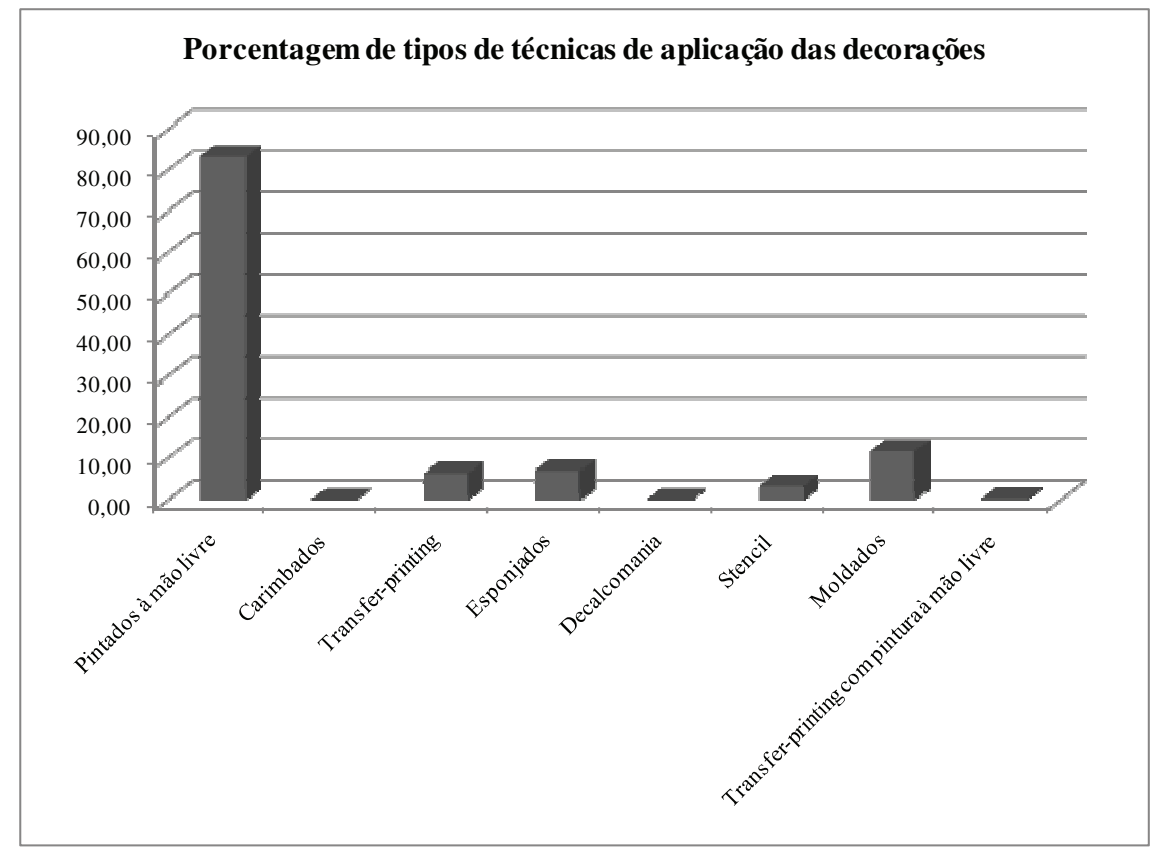

No que concerne aos padrões decorativos e motivos identificados, tem-se o seguinte:

\section{Em superfícies não-modificadas (cromáticas)}


Florais

$>$ Guirlandas

L Laçaria

$>$ Esponjado

$>$ Faixas e frisos

Arabescos

$>$ Rendas

Pontos

Couraça

Antropomorfos

$>$ Ovas

$>$ Geométricos (quadrados e círculos)

Willow

- Florais: os florais são motivos representativos de elementos da flora como frutos, folhas, galhos, gavinhas, sementes, flores, pétalas, raízes, etc. A designação é bastante genérica e em geral se refere àquelas decorações pintadas à mão livre; no entanto, existem motivos florais aplicados em diferentes técnicas, como o transfer, carimbadas, etc. Por isso é difícil a separação, uma vez que não conseguimos identificar cada tipo de flor. No acervo do sítio Petybon, a maior parte das peças com decoração floral foi pintadas à mão livre e classificadas segundo algumas variantes, ou seja, variações decorativas numa mesma técnica (TOCCHETTO et alli 2001: 25). Abaixo, listo os tipos de floral, incluindo alguns com diferentes técnicas de aplicação.

\footnotetext{
$\checkmark$ Margaridas

$\checkmark$ Florais com gavinhas

$\checkmark$ Cristas

$\checkmark$ Floral sobre fundo pintado

$\checkmark$ Fitomorfos com pontos

$\checkmark$ Flor do maracujá

$\checkmark$ Fitomorfo

$\checkmark$ Floral com laçaria

$\checkmark$ Tulipa
} 


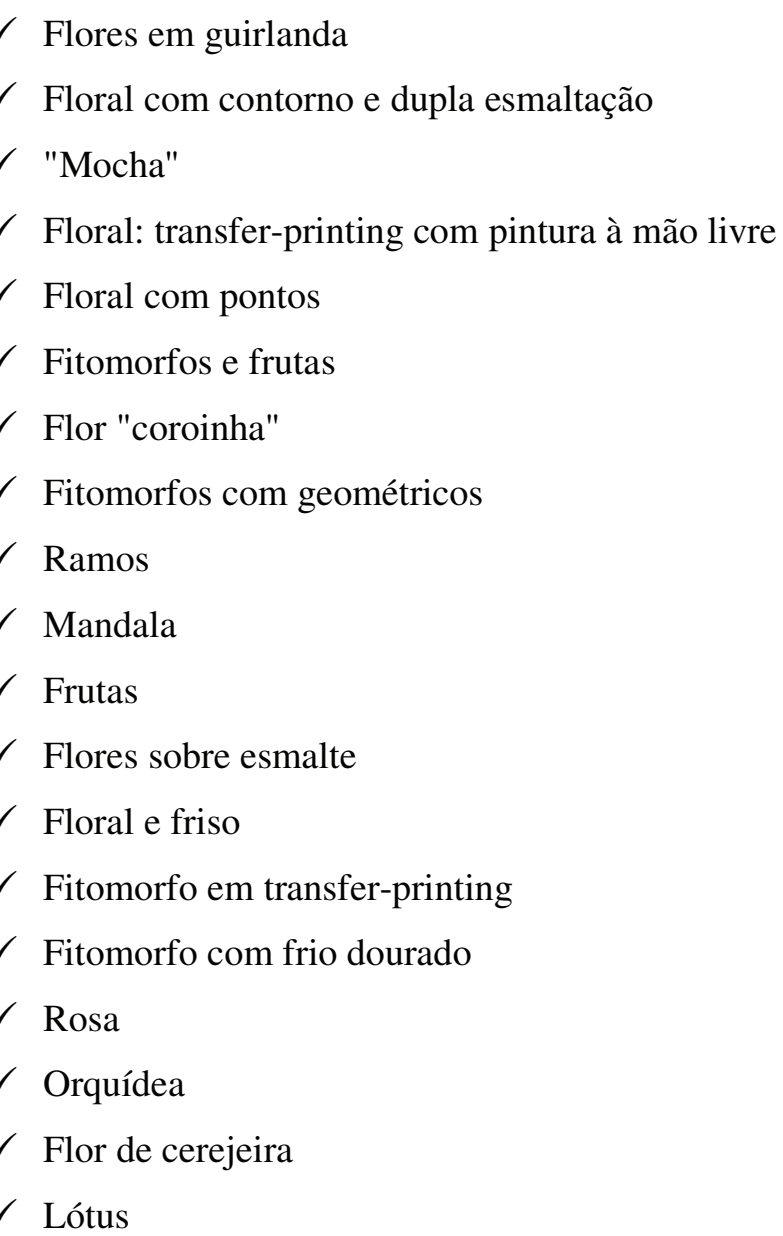

- Guirlandas: este padrão decorativo caracteriza-se pela presença da representação do ornamento, em geral circular ou em semicírculo, feito de flores, folhas e/ou ramagens entrelaçadas. A guirlanda apareceu apenas em transfer-printing.

- Laçaria: decorações compostas por laços.

- Esponjado: padrão decorativo, aplicado pela técnica do esponjado, consistindo em molhar a esponja na tinta e bater a mesma, levemente, sobre a superfície do suporte, originando um efeito de sombreamento e textura, no que concerne uma sensação visual. Presente apenas em malgas. 
- Faixas e frisos: padrão decorativo caracterizado pela presença de faixas, frisos, e faixas e frisos, com variantes na organização destes elementos, mono e policromados. Presente em pratos e malgas.

- Arabescos: elaboradas decorações em formas geométricas, com curvas, que se assemelham a plantas; aplicado apenas através de pintura à mão livre. Presente apenas em malgas.

- Rendas: padrão em transfer-printing representando linhas cruzadas, formando losangos, dando aparência de um tecido rendado. Presente apenas em malgas.

- Pontos: pontos, ou dots, é um padrão aplicado à mão livre, policrômico. Presente apenas em malgas.

- Couraça: decoração em transfer cujos pequenos detalhes, repetitivos, dão a aparência de uma couraça de armadura. Presente apenas em pratos.

- Antropomorfos: padrões decorativos que contém elementos antropomorfos. São de dois tipos: um em transfer, no qual há o busto, de perfil, de uma representação feminina grecoromana, e um associando transfer a carimbado, com a presença de um camafeu no qual há um busto feminino (ao que chamei "camafeu com rendas"). Presente apenas em malgas.

- Ovas: elemento presente em transfer-printing, encontrado também em algumas louças estrangeiras, caracteriza-se pela presença de "ovas", formas alongadas, como uma prancha de surf, repetidamente dispostos adjacentes por toda a aba. Presente apenas em pratos.

- Geométricos: decorações caracterizadas pela presença de quadrados e círculos.

-Willow: o já bastante conhecido e extensamente pesquisado Willow Pattern. 


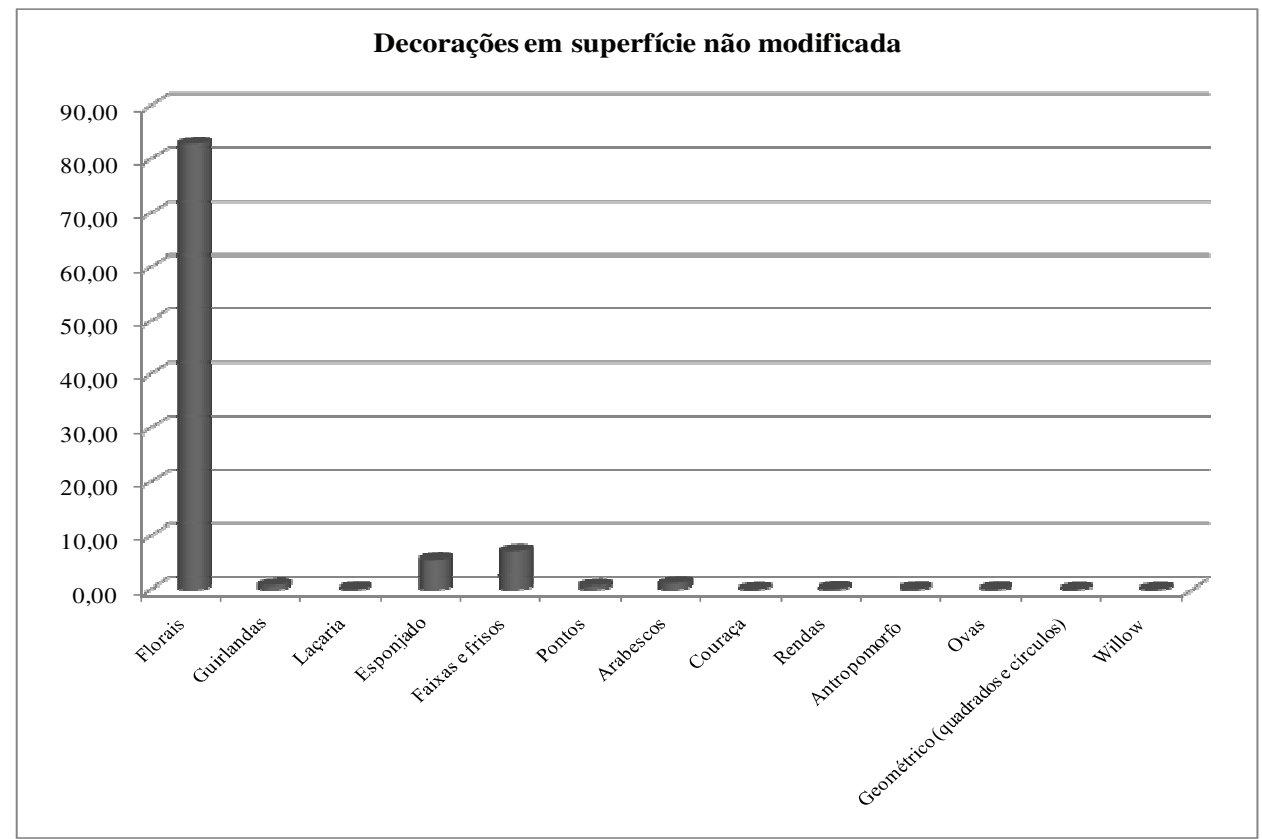

* Em superfícies modificadas (acromáticas)

Trigal

Retângulo com arestas arredondadas

Lírio

Linha em meia lua (moldado, na caldeira)

Borda ondulada

Concha

Não Identificados

\section{Percentual de decorações moldadas (em superfície modificada)}

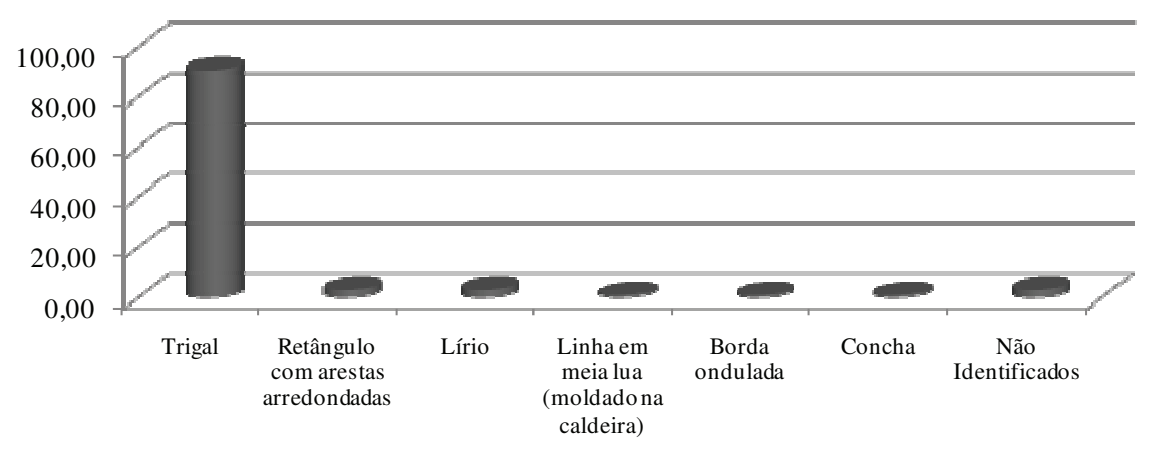


No que diz respeito às terminologias "motivo" e "tema", utilizo a distinção de Erwin Panofsky (1991). O "motivo" se refere às formas puras representativas de objetos naturais como animais, plantas ou um artefato qualquer. O "tema" seria a composição feita com os motivos, somados a assuntos e conceitos, conformando um significado (PANOFSKY 1991). Assim, um tema constituir-se-ia na "proposição de que se vai tratar num discurso" ou no “domínio de assuntos preferencialmente tratados numa obra” (HOUAISS 2001). A decoração como um discurso, ou a louça como uma obra, apresenta proposições ou assuntos que abordam, como mostrarei mais à frente nesta dissertação, o tema do bucólico.

\section{- Louças teste}

A coleção do sítio Petybon contém muitos exemplares do que denominei "louças testes", louças pintadas, cujas pinturas não são decorações ou não possuem um fim decorativo quando de sua produção. Refiro-me, deste modo, àquelas louças que são parte do cotidiano fabril e nos remetem a presença de redes de ensino-aprendizagem neste ambiente considerado opressor. Apesar de não poder afirmar pela análise gestual, acredito que estas louças também se refiram à enorme presença de crianças no universo produtivo. Como "louças testes" também classifiquei aqueles recipientes que foram utilizados, por exemplo, para limpar pincéis, tirando o excesso de tinta ou testando os pigmentos; ao fazer isso, o decorador ou decoradora desenhava formas neste suporte. Destaco, igualmente, a presença de louças no biscoito com marcas a lápis na forma de contornos e desenhos (trato com maior a finco destes aspectos no capítulo sobre as inscrições). São predominantemente artefatos no biscoito, os quais, na amostra analisada, representam 27 peças. 


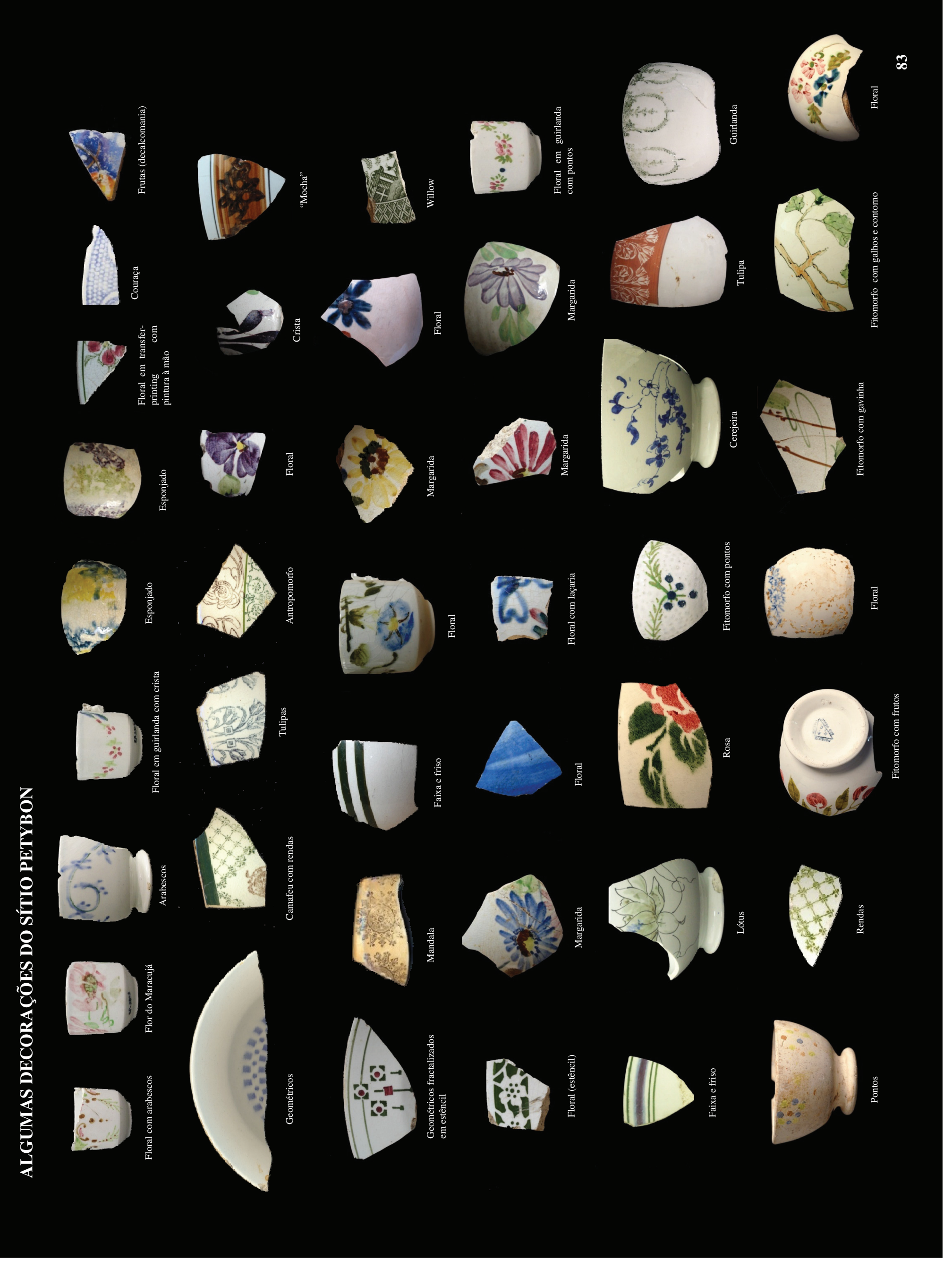



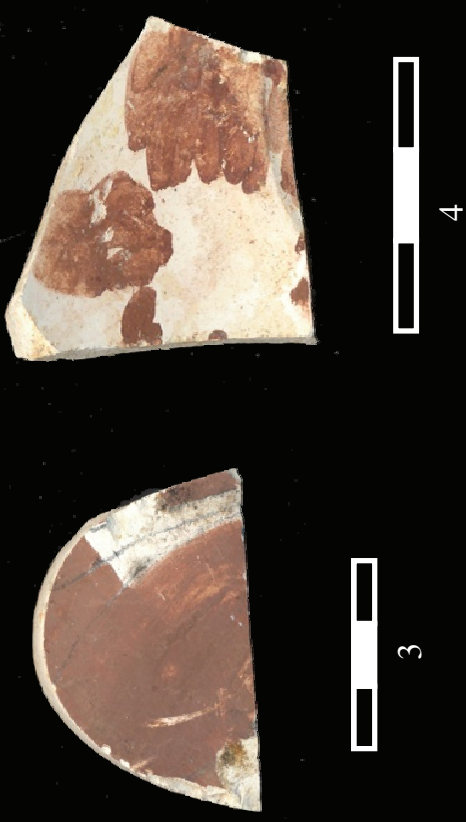

$\Pi^{n}$
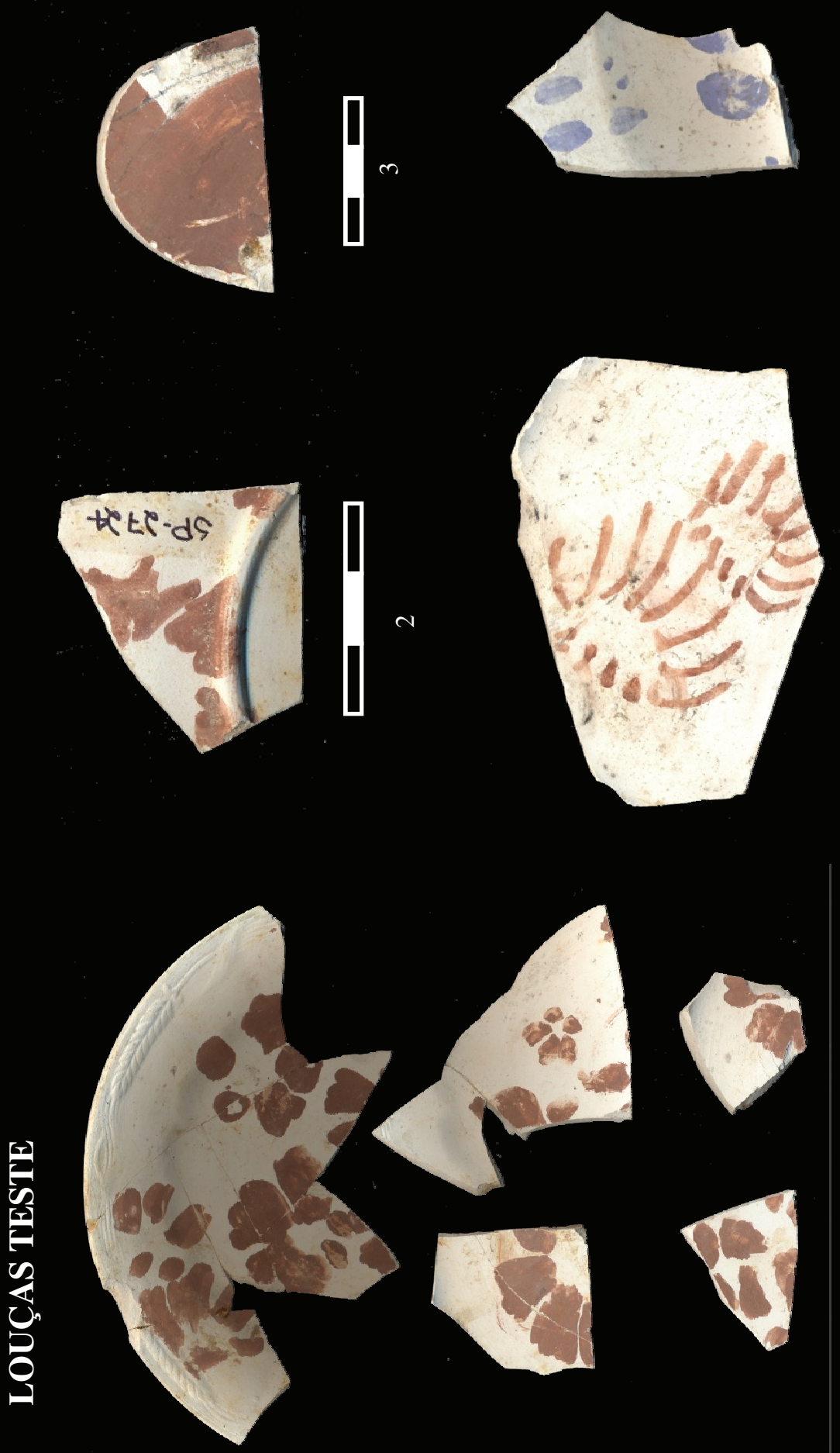
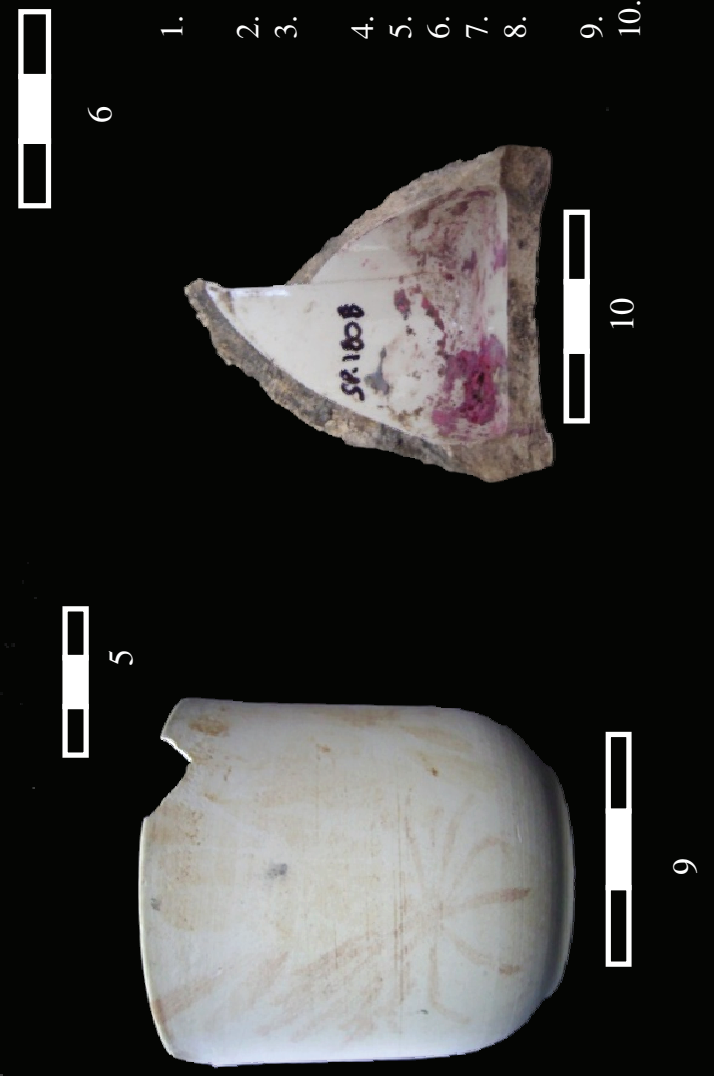

-

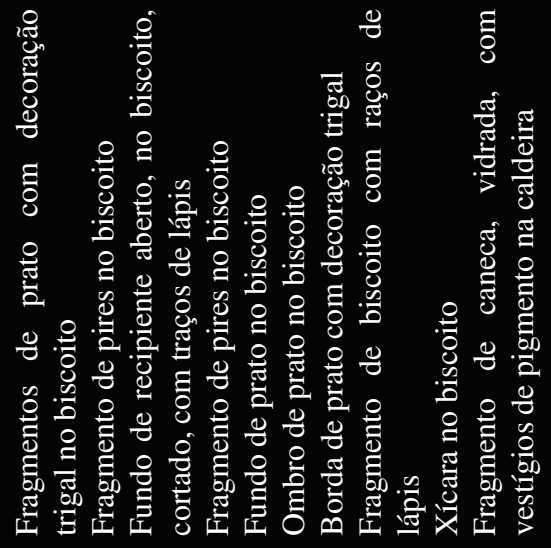

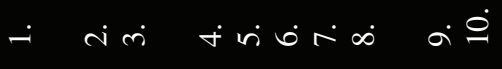
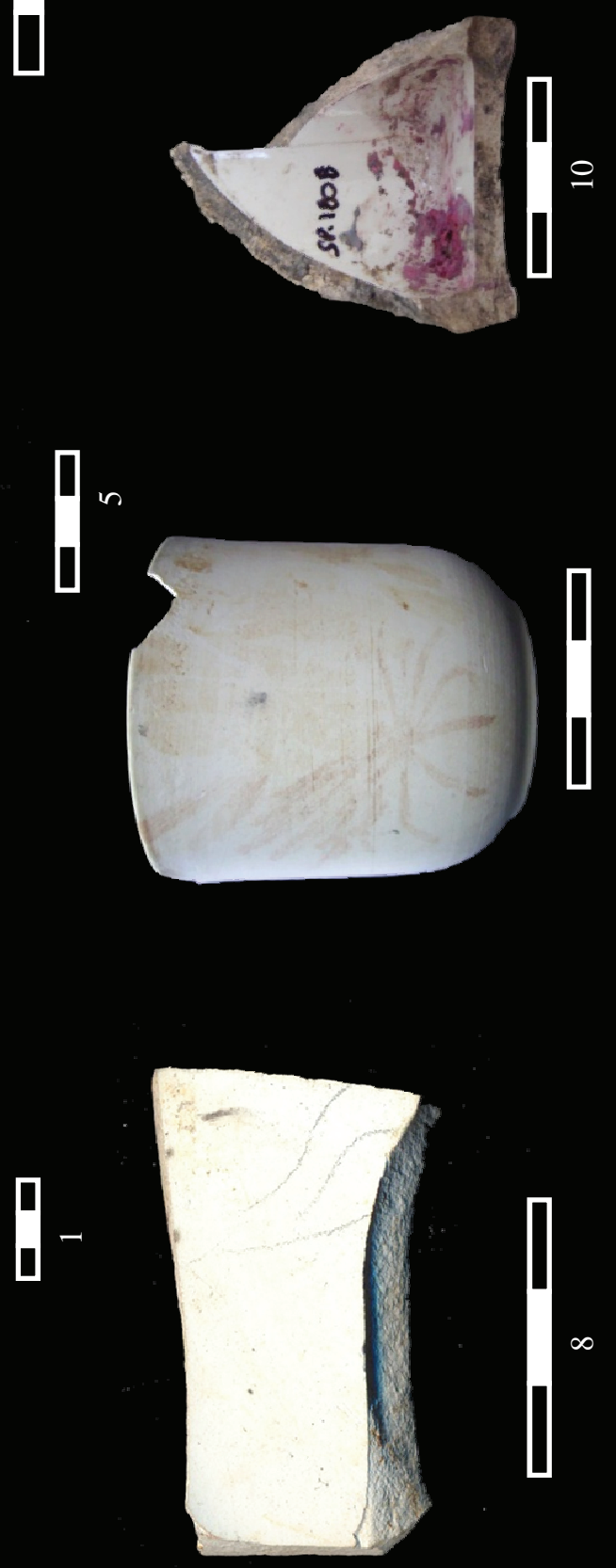


\section{C) Espessura}

De acordo com alguns princípios de análise de categorias cerâmicas, a medição da espessura é bastante corrente. A espessura de uma peça cerâmica vai variar de acordo com seu tamanho e também com seu uso pretendido. Diferente de peças torneadas ou acordeladas, onde a espessura da parede é também estrutural para a sustentação da forma, com o processo de louças por colagem, as paredes dos moldes agem como suportes para as paredes das louças, as quais podem, assim, ter sua espessura adelgaçada. No entanto, não é tão simples fazer louças de pouca espessura e nem é um caminho "natural" da demanda da louça o consumo por peças de espessura delgada, como mostrarei a seguir.

Sabe-se que espessuras finas conduzem o calor com maior facilidade (se as louças têm função de serviço, esta é uma característica pouco desejada - assim a importância de alças) e aumentam as probabilidades de quebra da peça por choques mecânicos (RICE 1987: 227). Paredes grossas, por outro lado, acarretam maior resistibilidade ao choque térmico e ao stress mecânico resultado de manuseio (SILVA 2000: 93). Nas louças do sítio Petybon, e acredito que nas louças brasileiras em geral, a espessura faz parte da cadeia operatória que caracteriza essa louça. Estou considerando, portanto, a espessura como um atributo e, consequentemente, como um traço cultural da produção desta louça, incorporado aos artefatos durante o curso de sua produção ("a process that involves a series of technical decisions that are "embedded in and conditioned by social relations and cultural practice" [DIETLER \& HERBICH apud DAVID \& KRAMER 2001: 140]).

Manipulando as louças em faiança fina nacional e as louças em faiança fina estrangeira, algo no toque das peças me fez perceber algumas diferenças, difíceis, então, de serem verbalizadas. No entanto, a medição das espessuras apontou algumas saídas. No que concerne a faianças finas feitas por colagem, a espessura está diretamente relacionada ao tempo que a barbotina fica dentro do molde de gesso. Este tempo interfere no sistema produtivo e no produto final, pois ele é diretamente proporcional a formação da camada por deposição da pasta em suspensão na barbotina. Com a colagem, a massa líquida (barbotina), derramada dentro de um molde de gesso, tem seus componentes, em suspensão, aos poucos, depositados nas paredes do mesmo. Quanto mais tempo a barbotina permanecer no interior do molde, maior deposição, maior a camada, mais grossa a espessura da peça. Em Fábricas como a Santa Catharina, e hoje a Porcelana Monte Sião, um operário faz a colagem, enchendo um número $x$ de moldes numa bancada. Ao término do enchimento do último molde da bancada, já deve 
estar em tempo de se virar o primeiro: "quanto ao produto final, a diferença de tempo determinará a diferença de espessura" (AUN 2000: 180).

Deste modo, a espessura é quase que totalmente controlada pelo operário, pela velocidade dos gestos do trabalhador. Enquanto primeira fábrica de louça branca do Estado, e a primeira do país em moldes industriais, a Santa Catharina não possuía uma mão de obra nacional especializada no fabrico de louças brancas. Assim, manipular e fabricar as chamadas "casca de ovo", ou louças com espessuras finas, era difícil e implicava em muitas perdas ao longo do processo produtivo. Requer-se certa experiência oleira específica para tirar as peças do molde sem amassá-las ${ }^{6}$. Por isso, optando por uma espessura mais grossa, diminui-se as probabilidades de rachar ou amassar a louça ainda crua, pré-biscoito. Se a louça for muito fina, ainda pode haver deformações durante a queima, e se for muito grossa pode haver comprometimento de encaixes e sobreposições, além de uma maior absorção de vidrado aplicado por banho ou imersão (AUN 2000: 181). Uma fábrica, e isso quer dizer também seus trabalhadores, deve estar ciente das características físico-químicas de sua barbotina para que a peça fique no molde tempo "suficiente" para formação da camada e para que se desprenda por si só. Se a peça for retirada antes do tempo, ela poderá deformar, porém a demora em sua retirada implicaria em rachaduras dentro do molde por encolhimento da peça (ROSSI 2007).

Se a espessura mais grossa foi adotada como procedimento mais funcional da produção de louças brancas no Brasil, com o tempo esta passou a ser quase que uma característica intrínseca dessas louças nacionais e tenho a impressão de que elas só engrossaram com o tempo (veja-se, por exemplo, a espessura de alguns pratos de porcelana brasileira!). É assim que se faz a louça em faiança fina, sem maiores questionamentos - estratégia tecnológica que resultou em uma escolha específica. Pressuponho, portanto, que "em todas as etapas envolvidas no processo de produção, circulação, utilização e descarte dos artefatos, ou em todas as atividades que compõem um sistema tecnológico, o sujeito que dele participa se depara com uma série de opções possíveis de serem empregadas, dentre as quais ele deve escolher sem que esteja necessariamente sujeito à regra básica da maximização da energia" (BUENO 2005: 21). Assim, algumas espessuras características de louças em faiança fina européias são, com menor

\footnotetext{
${ }^{6}$ Quando conversei com o Senhor Carlos Alberto Daldosso, um dos filhos de Antônio Daldosso (“Seu Toninho”), sócio da Porcelana Monte Sião, sobre o assunto, segundo ele a espessura é uma opção da fábrica e tem a ver com o grau de especialização dos trabalhadores. Quanto menor a espessura, maior as probabilidades de quebra ao retirar as peças dos moldes. Os chineses, por exemplo, tinham técnicas milenares e especializadas para tal, coisa que o Brasil não tinha. A mesma coisa tem a ver com a granulometria das pastas que no Brasil é maior. $\mathrm{O}$ processo é o mesmo da porcelana, mas ao mesmo tempo é um pouco mais "rudimentar", já que não é porcelana fina. Grãos maiores na pasta acarretam uma maior espessura das formas (Entrevista realizada em 13 de Outubro de 2006. O senhor Carlos trabalhou por 24 anos na fábrica, começando aos 12 anos).
} 
freqüência, encontradas nas louças brasileiras (como, por exemplo, espessuras entre 1 e $2 \mathrm{~mm}$ ), sem mencionar algumas louças orientais em porcelana.

Com fins comparativos, utilizo dados de outros sítios arqueológicos com presença de louças em faiança fina, a saber sítio Fonte do Campo (NASCIMENTO 2009; ZANETTINI ARQUEOLOGIA 2008), Cananéia 3 (BAVA DE CAMARGO 2009), Saco da Armação (GUIMARÃES 2008), Fazenda Brejão (ZANETTINI ARQUEOLOGIA 2004). Quanto à cronologia, o sítio Cananéia 3 pertence ao final do século XVIII e começos do XIX, os sítios Fonte do Campo do século XIX, mas contêm louças do século XX, Saco da Armação, da segunda metade do século XIX, mas igualmente com presença de louças brasileiras, e o sítio Fazenda Brejão, da primeira metade do século XX. O que percebi foi uma sutil, mas presente, variação entre as espessuras em direção às louças do século XX. Se no sítio Cananéia 3 as espessuras se concentraram entre 2 e $3 \mathrm{~mm}$, na Fonte do Campo a maioria está entre 3 e $4 \mathrm{~mm}$, assim como no Saco da Armação. Nos sítio fazenda Brejão e no Petybon as espessuras concentram-se já acima de 3,5, talvez entre 3 e $5 \mathrm{~mm}$. É preciso lembrar que o único sítio com total ausência de louças brasileiras é o Cananéia 3.
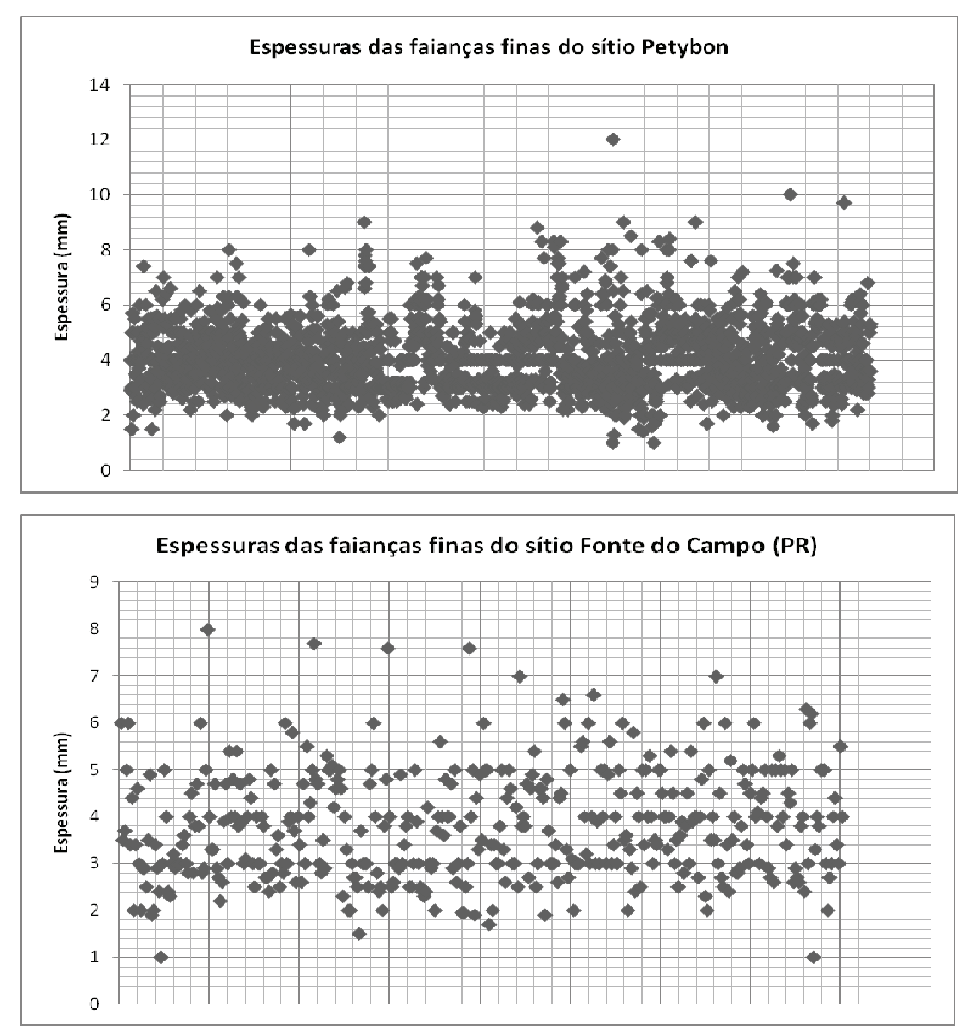

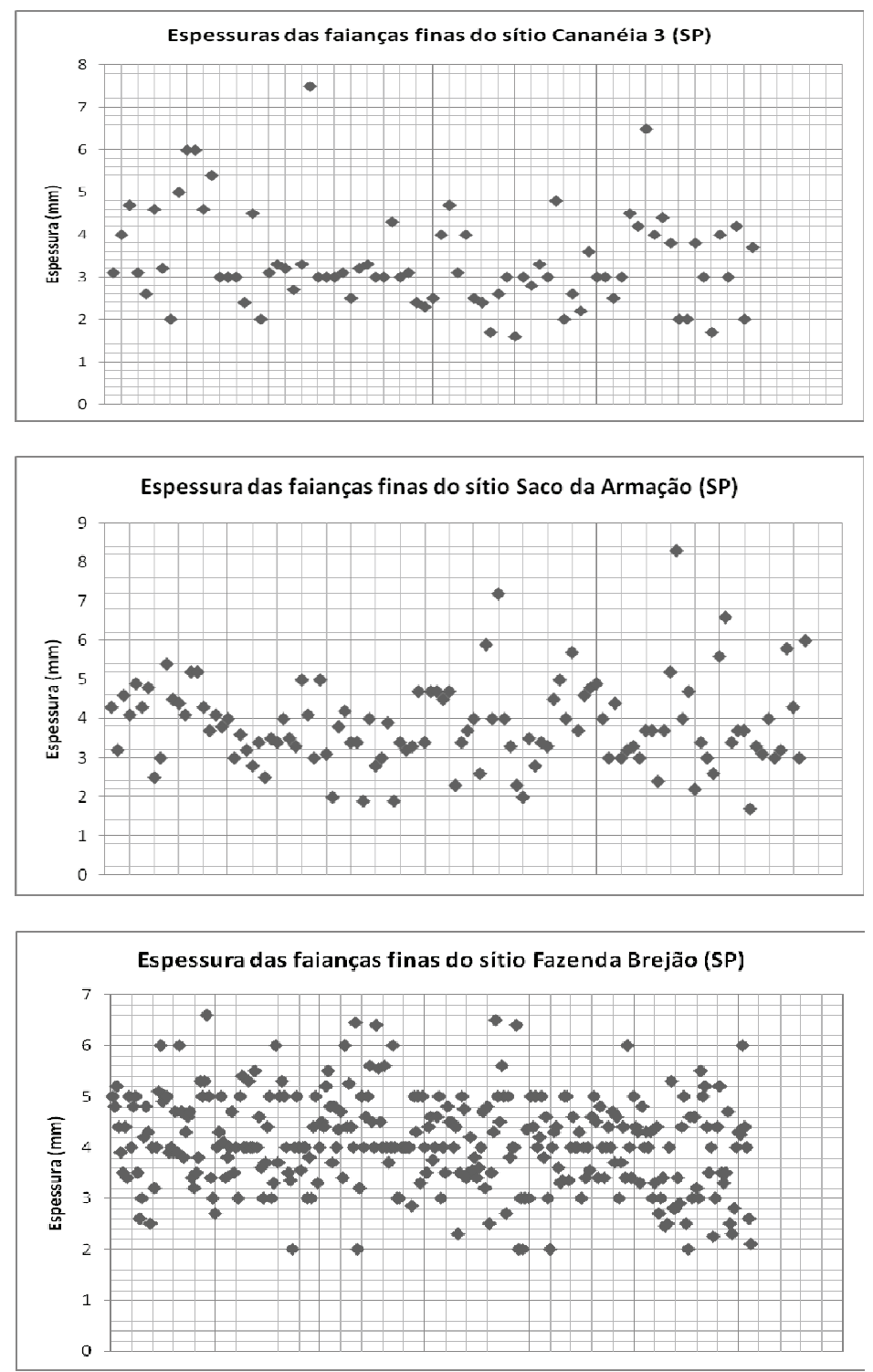

Os sítios com escopo temporal mais recuado, Cananéia 3 e Fonte do Campo, possuem louças com as menores espessuras, diferente do que acontece com a Fazenda Brejão e sítios que contém material do século XX, como a própria Fonte do Campo. Apesar disso, um olhar sincrônico aponta na direção de uma certa homogeneidade na produção da faiança fina no mundo, na qual fica marcada que este tipo de cerâmica está preso a um máximo (6mm) e a um mínimo $(1 \mathrm{~mm})$ no que concerne à espessura de suas paredes.

\section{D) Etapas do processo produtivo}


Enquanto universo produtivo, o sítio Petybon contém diversos artefatos em diferentes etapas do processo de produção, assim como artefatos associados a esta produção. Através deles pode-se reconstituir a cadeia operatória da produção de faiança fina na antiga Fábrica de Louças Santa Catharina e muitos dos gestos que deixam marcas específicas nas superfícies destas louças. Portanto, as peças foram analisadas seguindo sua localização em cinco etapas da cadeia: biscoito, biscoito com decoração, biscoito com vidrado cru, biscoito com vidrado cru e decoração, e vidradas.

Lembro que a faiança fina sofre duas queimas (e às vezes uma terceira dependendo da decoração, se esta for sobre o vidrado). Depois da primeira queima, o resultado é o biscoito, uma louça porosa sobre a qual será aplicada a decoração e depois o vidrado, para, então, ir ao forno pela segunda vez (ZANETTINI 1986; PILEGGI, 1958, BRANCANTE 1993). O biscoito é a peça mais "recuada" na linha da cadeia de produção que sobreviveu no sítio arqueológico, visto antes dele existir apenas a peça crua, queimada após uma seção de acabamentos e tratamentos de superfície.

Os biscoitos com decoração são os biscoitos nos quais foram aplicadas as decorações pintadas, mas ainda não vidradas. Biscoitos com vidrado cru são as peças nas quais o biscoito está coberto com vidrado não fundido, reconhecível por uma camada pulverulenta rosada que cobre a peça. Biscoitos com vidrados crus e decoração são as peças nas quais a decoração foi aplicada sobre os biscoitos que foram, então, vidrados, mas não sofreram, ainda, a segunda queima. Peças vidradas são as peças teoricamente finalizadas, que já sofreram a segunda queima. O sítio Petybon contém $93 \%$ das peças no biscoito e apenas $7 \%$ vidradas, que foram analisadas segundo as etapas elencadas anteriormente e que podem ser vistas no gráfico abaixo:

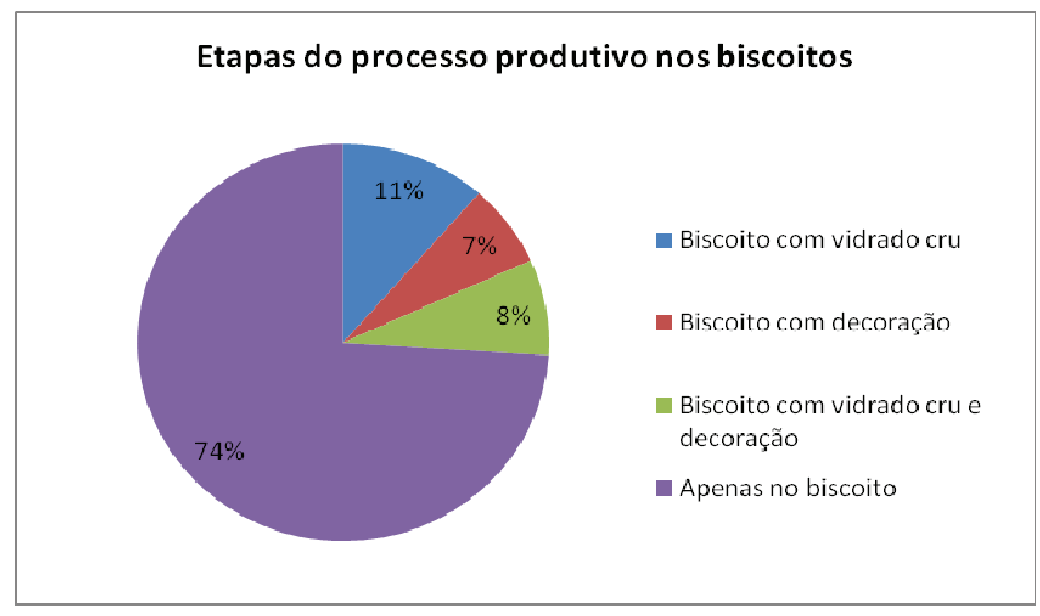




\section{E) Tratamentos de superfície}

Como tratamento de superfície nas louças em faiança fina entendo os atributos relacionados às técnicas de acabamento da superfície das peças, observáveis tanto na superfície externa como na interna (MORAES 2007). Foram observados dois tipos de tratamento: acabamentos e aplicação de vidrados. Não quero dizer que os vidrados nas faianças finas não sejam também aspectos da decoração e tenham um apelo estético, além de funcional, mas, por razões didáticas, os analisei, primeiramente, como um tipo de tratamento dado às superfícies destas cerâmicas. Quanto ao que chamei acabamentos, só foi possível observá-los nas peças nos biscoitos.

\section{Acabamentos}

Para as louças, entendo como acabamento o que pude observar, hoje, nas fábricas de porcelana brasileira no "Setor de Acabamento" (e por isso utilizo o termo), que antecede a queima do biscoito. Para a cerâmica, são elencados diversos tipos de acabamento levados à cabo após a confecção do recipiente, com a argila ainda úmida, que servem-se de variados instrumentos, tais como seixos rolados, sabugos de milho, taquaras e mesmo as mãos (MORAES 2007). Para as faianças finas estudas aqui, uma vez retiradas dos moldes, são acumuladas para secagem ao ar livre, onde pode ocorrer acúmulo de poeiras, além de pequenos fragmentos de massa ou do gesso do molde que podem ter se aderido á superfície das peças. Para eliminar estes vestígios, são aplicados aos biscoitos alguns tratamentos. No sítio Petybon, pude perceber dois tipos de acabamento: o primeiro deixa marcas semelhantes a um pano ou esponja e está presente no interior de recipientes côncavos e no exterior e interior de formas abertas; já o segundo, deixa linhas incisas na parte externa das peças côncavas, podendo caracterizar-se por linhas paralelas ou em espiral. As peças côncavas possuem também marcas em espiral na parte externa do fundo indicando que, ao sofrerem os tratamentos de superfície apontados anteriormente, estavam sobre um suporte giratório, como um torno. Todos estes acabamentos de superfície, ao final, podem ser encarados como uma espécie de alisamento, um "processo de nivelação da superfície do vasilhame" (CHMYZ 1976: 121).

O acabamento com a esponja era realizado em toda a superfície interna do vasilhame, horizontalmente. $\mathrm{O}$ acabamento com os instrumentos que deixam as marcas circulares ou espiraladas ocupa toda a superfície externa dos vasilhames nos quais eram feitos, sendo que a 
distância entre as linhas diminui ao aproximar-se da base. Há possibilidades, igualmente, deste tratamento de superfície ter sido feito em pratos e outras formas abertas, deixando marcas que foram apagadas pelo posterior uso da esponja.

Nesta cadeia de produção, parece não haver muita preocupação com as marcas deixadas pelos acabamentos, uma vez que, mesmo depois da queima do vidrado é possível observar, em algumas peças, essas marcas, traço bastante comum em produções em série, onde, em geral, há mais preocupação com a quantidade produzida e menos com a qualidade da produção.

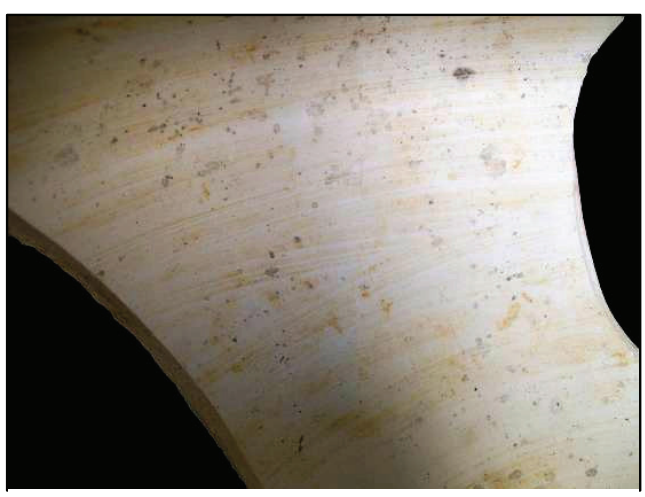

Esponja ou pano interno

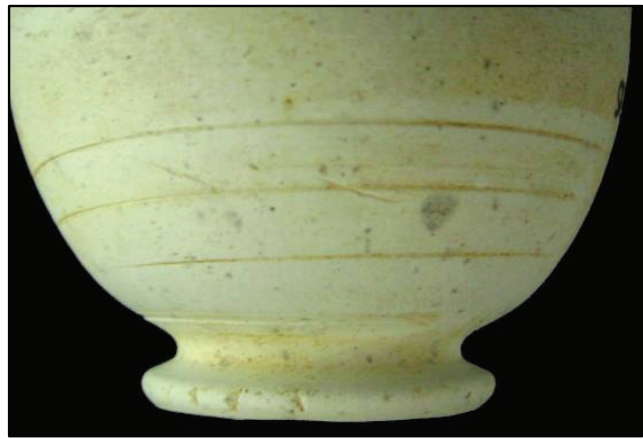

Linhas incisas em espiral

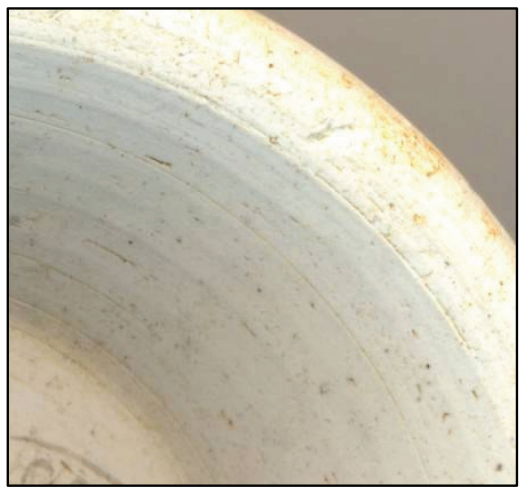

Marcas por pressão formando círculos concêntricos

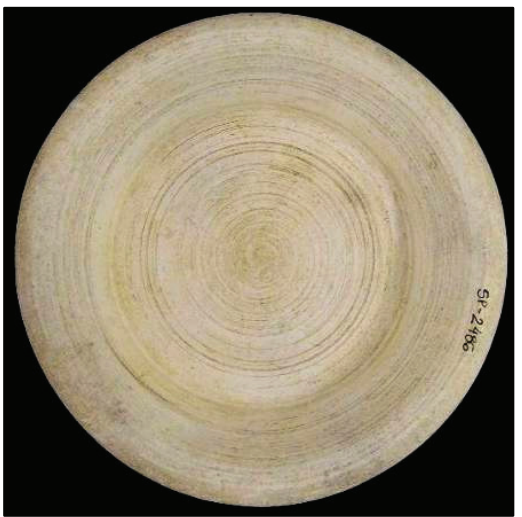

Linhas incisas concêntricas na base

\section{Vidrados / Esmaltes}

Dentre os atributos analisados em faianças finas, o chamado "esmalte" tem suma importância, no que concerne a identificações cronológicas e de proveniência (KINGERY \& VANDIVER 1986: 261). Os vidrados ou esmaltes constituem um tipo de tratamento de superfície de peças cerâmicas, assim como engobos, bruniduras e alisamentos. Primeiramente, 
quero esclarecer que estou me valendo do termo "vidrado" por uma opção didática, sabendo que esmalte e vidrado tem o mesmo significado, apesar de "esmalte" já ser uma nomenclatura bastante consagrada na Arqueologia Brasileira e em meios ceramistas e antiquários (o próprio Ranzini em seus cadernos de nota utiliza o termo "verniz"; o termo "frita" é em geral usado por ceramistas e em menor frequiência a bibliografia traz "glazura"). Não obstante, tecnicamente, algumas áreas como a Engenharia de Produção diferenciam vidrado de esmalte. Segundo Chaves (1997: 22), "vidrados são coberturas vítreas aplicadas sobre superfícies cerâmicas porosas, de modo a dar-lhes acabamento e impermeabilizá-las", enquanto que "esmaltes são coberturas vítreas aplicadas sobre superfícies metálicas (...) O esmalte protege a superfície metálica da oxidação e o metal dá resistência mecânica (exceto ao impacto) ao conjunto".

Para Cristiane Aun (2000: 110), os vidrados "são finas misturas de silicatos, geralmente homogêneas, aplicados sobre a superfície de peças cerâmicas na forma de uma suspensão aquosa, e que, após a queima em alta temperatura, têm seus componentes fundidos, formando uma camada vítrea delgada". Para Norton "o vidrado é uma fina capa de vidro, ou de vidro de cristais, cozida sobre a superfície da cerâmica em estado cru ou em estado de biscoito". Para Terezita Férnandez (1997), “o vidrado não é mais que aquele composto que apresenta uma superfície vitrificada depois da queima. Sua principal característica é a de impermeabilizar a peça além de ser muito resistente e servir de proteção". Da coleção, 2.646 peças estão vidradas e o gráfico abaixo mostra a quantidade de peças vidradas e no biscoito por categoria funcional (somando universos 2 e 3) na amostra das coleções MAE, IPHAN e NAUBC.

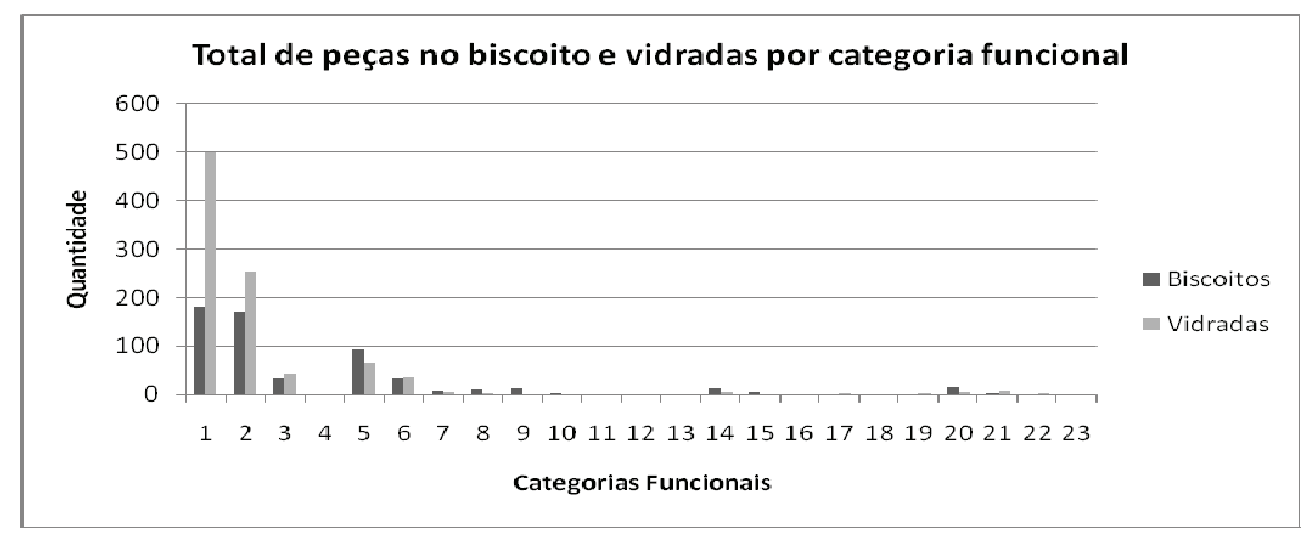

A descoberta da faiança fina inovou o processo de produção das louças em relação à antiga faiança, pois a decoração passou a ser aplicada diretamente sobre a pasta branca, o biscoito, que ganha, por cima, um vidrado, em geral transparente. Vidros, vidrados e esmaltes 
podem ter sua cor ou transparência alteradas mediante a adição criteriosa de pigmentos ou opacificantes (CHAVES 1997: 22), daí a classificação, de língua inglesa, que se utilizou e criou, para as faianças finas e as tênues colorações dos vidrados transparentes, os termos creamware (adição de óxido de chumbo), pearlware (adição de óxido de cobalto) e whiteware (redução de óxido de cobalto). No entanto, não estou utilizando esta classificação aqui, ou melhor, para efeito de comparação, estou utilizando esta classificação para demonstrar como às vezes é falha.

Deste modo, segundo a classificação geralmente utilizada, teríamos para as louças do Petybon, na amostra das coleções IPHAN, MAE e NAUBC, a seguinte relação: 603 peças pearlware, 13 creamware e 23 whiteware, portanto, um claro predomínio do vidrado "perolado". Através da análise química ficou provado, no entanto, que todos estes vidrados, no sítio Petybon, são compostos, majoritariamente, por chumbo, sem adição de cobalto, sendo, portanto, o mesmo vidrado.

O pearlware é definido, na literatura, como com adição de óxido de cobalto, que o faria ser azul. Ele, no entanto, é um vidrado que tem uma produção certa, assim como uma cronologia determinada. Se fosse utilizar o termo aqui, ele já seria falho porque indicaria que nem todo pearlware remete-nos ao século XIX. Contudo, algumas amostras do sítio Petybon, caracterizadas como pearlware, creamware e whiteware, foram analisadas físicoquimicamente, e se constatou que os vidrados apresentaram altíssima taxa de chumbo ${ }^{7}$. Portanto, apesar da coloração azulada, o vidrado tem apenas chumbo, não há cobalto. Mais a frente, retornarei a esta questão explicando mais detalhadamente a problemática desta classificação e porque não a adotei, e ainda a critico.

Em segundo lugar, quero esclarecer porque a faiança fina não é uma cerâmica vitrificada, da qual faz parte, por exemplo, o grès, e, sim, uma cerâmica vidrada. A faiança fina é um tipo de cerâmica vidrada por receber em sua superfície um vidrado. As cerâmicas vitrificadas não recebem uma camada de vidrado, pois devido às características da argila e ao processo de cocção a altas temperaturas, é a superfície da própria cerâmica que vitrifica. Vitrificação é o processo no qual vidro é formado no corpo das cerâmicas, quando minerais silicatos e óxidos são aquecidos o suficiente para que se fundam, formando um líquido viscoso (RYE 1981: 108). Nas cerâmicas vidradas o que vitrifica é o vidrado e não a superfície do biscoito.

\footnotetext{
${ }^{7}$ Foram analisados pelo Laboratório de Física Nuclear da UEL (Universidade Estadual de Londrina), no Paraná, pelo Prof. Dr. Carlos Appoloni.
} 


\section{F) Processo de Esmaltação}

Os processos de esmaltação caracterizam-se não apenas pelo modo de aplicação dos vidrados às superfícies das louças, mas igualmente pelas etapas realizadas entre esta aplicação e a segunda queima. Ou seja, dependendo da fábrica, por exemplo, uma esponja é passada na base das peças, após a aplicação do vidrado por imersão, para a formação de um aro no biscoito que não aderirá à superfície da caixa refratária, dentro das quais as louças são queimadas; na Fábrica, percebi que um processo diferenciado ocorreu: a utilização de mobiliários do forno, como apoiadores e trempes, implicando na não obrigatoriedade do aro no biscoito, já que as peças não tocam diretamente as superfícies refratárias e o vidrado não fundiria com estas durante a segunda queima.

Na Fábrica Santa Catharina, o vidrado parece ter sido aplicado por imersão, ou seja, mergulhando as peças num tanque com o vidrado em suspensão aquosa. Não é à toa ser conhecido também como "frita"; para fabricá-lo seus componentes são "fritos" formando uma massa, como um vidro líquido, que é, então, transformada em folhas transparentes, já frias e endurecidas. Estas folhas são, então, moídas e o que, em geral, se vende às fábricas é este pó. Dissolvido em solução aquosa, é então aplicado aos biscoitos.

No sítio Petybon, portanto, foram estipulados dois tipos de processos de esmaltação: com biscoito aparente na base e sem o biscoito aparente na base, sendo que este último foi diagnosticado em 285 peças do total de peças vidradas da amostra da coleção IPHAN, MAE e NAUBC, no Universo 3. Abaixo, segue exemplo dos dois processos com material proveniente de outros sítios arqueológicos.

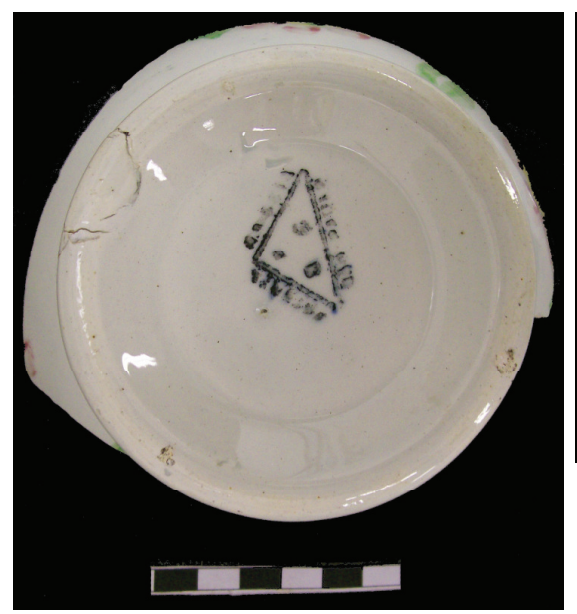

Sítio Petybon - fragmento de malga

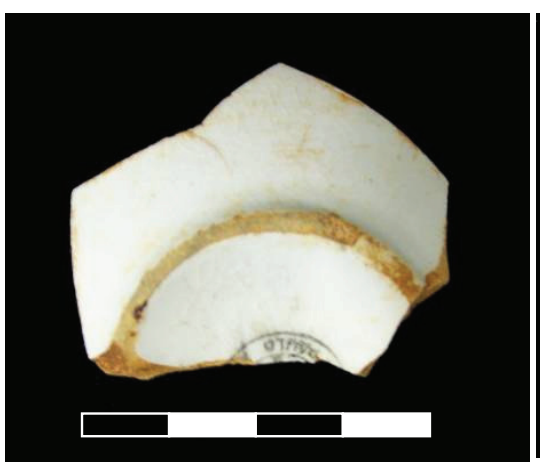

Sítio Fazenda Brejão - fragmento de malga com marca CPF (Cerâmica Porto Ferreira) (ZANETTINI ARQUEOLOGIA 2004)

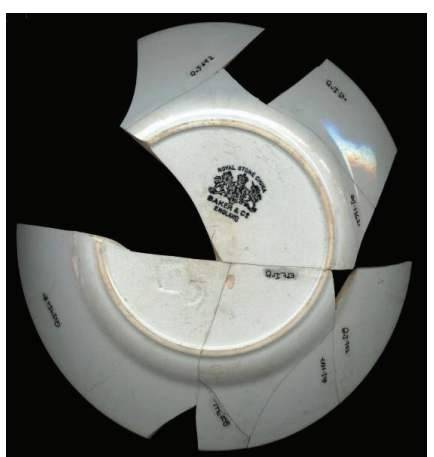

Sítio Baixio dos Lopes (PE) prato com marca Baker \& Cia, ENGLAND (ZANETTINI ARQUEOLOGIA 2008) 


\section{G) Defeitos}

Enquanto um universo produtivo, o sítio Petybon apresenta, além das peças em diferentes etapas do processo de produção, peças que possivelmente foram descartadas devido à problemas ocorridos durante sua fabricação, os defeitos - resta, saber, se os defeitos por mim diagnosticados foram, realmente, causas de descarte. Dentre os defeitos que podem ocorrer no vidrado e na própria superfície cerâmica, foram diagnosticados na coleção os seguintes problemas:

1) Bolhas

2) Partículas inorgânicas que caíram sobre o vidrado durante a queima ou após a esmaltação (fragmentos de fôrma, massa, quartzo ou outras sujeiras) e que se fundem à superfície

3) Defeitos na decoração

4) Partículas inorgânicas que estão sob o esmalte ou sob a superfície do biscoito, que caíram na peça antes da esmaltação.

5) Espirro ou mancha de tinta

6) Muito esmalte acumulou deixando manchas azuladas

7) Amassados ou deformados

8) Rachaduras

9) Vidrado perdeu o lustre e se tornou um pouco rugoso devido à volatilização da superfície do mesmo

10) Vidrado descolou

11) Início de vitrificação na superfície do biscoito deixando o mesmo com cor "mate", como o grès.

12) Fusão de duas ou mais peças durante a queima do biscoito ou a queima do vidrado

13) Espessura muito grossa (tempo demasiado da barbotina no molde de gesso)

14) Marcas de dedo sobre o vidrado

15) Marca da Fábrica carimbada na parte interna da peça 
O gráfico abaixo mostra os tipos de defeito por quantidade na amostra da coleção analisada. Fica clara a predominância dos defeitos 2, 1, 3 e 7 - defeitos que ocorrem mais freqüentemente em etapas de queima.

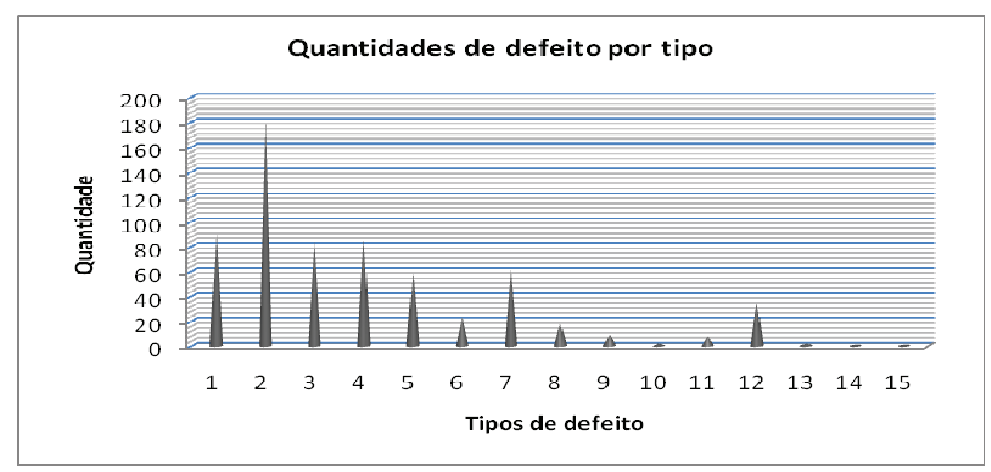

Amassados e deformidades corresponderam a 61 artefatos do total de peças com defeito analisadas na amostra, 9\% do total. Podem ser causados tanto pela manipulação da louça crua, saída do molde, como por problemas devido às altas temperaturas ou alteração do ponto de fusão, já dentro do forno. Por isso, uma espessura mais grossa diminuiria estas probabilidades.

Um dos defeitos mais freqüentes verificados nas louças são as bolhas no vidrado, como se o mesmo tivesse "fritado". As bolhas no vidrado podem ocorrer por diversos fatores durante a produção, mas causas comuns são: deixar as louças menos tempo do que o previsto no forno durante a segunda queima, deixar que fragmentos de lenha queimada se misturem a atmosfera do forno alterando o ponto de fusão dos vidrados e, finalmente, a presença de oxigênio na atmosfera do forno. Às vezes, juntamente com as bolhas, pode-se perceber um tipo de enrugamento do vidrado na superfície da peça, em geral provocado tanto pela aplicação de vidrado em excesso como por oscilações da temperatura de queima no forno (FERNANDÉZ 1997). Correspondem a $14 \%$ do total de peças com defeito na coleção analisada.

Um total de 5\% corresponde, na coleção, às peças, no biscoito ou vidrado, fundidas umas às outras, defeito ocorrido por algum problema entre os separadores e apoiadores, que resultou na união das peças durante a queima, "grudando-as". Esta porcentagem corresponde a um total de 35 peças, mas devo lembrar que quatro artefatos com este tipo de defeito são compostos por 2 malgas, 8 pratos, 18 pratos e 1 travessa, e 3 pires, respectivamente, todos fundidos uns aos outros.

Algumas peças apresentaram um amarronzado na superfície do biscoito, algumas vezes brilhoso, que correspondem a $1 \%$ do total, 8 peças. É de se pressupor que foram biscoitos que 
sofreram queima a uma temperatura alta demais, que levou ao início de uma vitrificação, tal como acontece com o grès.

Algumas louças continham fragmentos de massa, forma ou partículas inorgânicas sob o vidrado, resultado de limpezas pouco eficientes das peças cruas pré-esmaltação, e sobre o vidrado. $\mathrm{Na}$ área onde as trempes tocam as bases das peças podem ser averiguados fragmentos, por vezes grandes, de pedaços de trempe e acumulo de vidrado. Estes defeitos, juntos, correspondem a $41 \%$.

Alguns defeitos apareceram apenas em 1 ou 2 peças, tal qual o caso de um descolamento do vidrado da superfície do biscoito, da presença de digitais sobre o vidrado, espessura muito grossa para um fundo de prato (com 9,7 mm) e um prato ou pires cuja marca está na parte interna da peça (no frete).

\section{H) Gretamento}

Ao analisar os atributos ligados ao processo de esmaltação, indubitavelmente fui levado ao diagnóstico de uma categoria extremamente relacionada às faianças finas, aos vidrados e aos defeitos, à qual chamo "gretamento". Este atributo é, geralmente, utilizado nas explicações a cerca do reconhecimento das faianças finas nos sítios arqueológicos, diferenciando-as das porcelanas, onde nunca ocorre, e ao qual se costuma denominar "craquelado". Adoto o termo "gretamento", vindo da Engenharia de Materiais, para que não haja confusão com uma decoração específica para louças chamada "craquelado" ou "craquelé" (craquelure em inglês). Enquanto decoração é proposital, uma ação consciente por parte do oleiro que escolheu e que quis aquele efeito decorativo, caracterizado por "rachaduras" na superfície da peça. Existe, atualmente, até mesmo um tipo de "verniz craquelador", que produzirá, propositalmente, vidrado com trincas, sendo que as trincas podem, depois, ser coloridas. $\mathrm{O}$ aspecto é desejado para dar um ar mais "antigo" às peças, sendo pouco usado em recipientes destinados a alimentação (quando ocorre, pode haver uma nova esmaltação sobre o vidrado craquelado). Nas Artes Plásticas, o craquelé é também um padrão de finas rachaduras que se formam em pinturas antigas, sendo às vezes usado para detectar obras falsificadas.

Em uma das cadernetas de Romeo Ranzini, sob salvaguarda atualmente do Museu Paulista, referente a seus trabalhos na fábrica que abriu em Osasco nos anos 1940, ele mesmo escreve no dia 24 de Janeiro de 1945: 


\section{Craquelé}

A massa granito J.RI - queimada primeiro no forno de verniz, depois, com verniz comum, a $1^{a}$ antiga e no mesmo forno de verniz, torna-se um lindo e esplendido "craquelé"

$\mathrm{Na}$ Arqueologia, quando nos referimos ao "craquelado" nas faianças finas, estamos nos referindo ao gretamento, efeito causado por tensão vidrado-cerâmica, pela abertura do forno com louças ainda quentes (KINGERY \& VANDIVER 1986: 267) e pela expansão por umidade da pasta, podendo ocorrer durante o uso ou após o descarte da peça, sendo, portanto uma ação inconsciente e não proposital dos usuários. Ninguém escolhe que a louça seja gretada, uma vez que isto não apenas relaciona-se a questões de higiene e limpeza, quando resíduos acumulam entre as gretas, mas é visto mesmo como defeito dos produtos cerâmicos e é, inclusive, bastante combatida.

Pressupostos os termos, define-se gretamento do vidrado como "um defeito que ocorre em peças cerâmicas vidradas, que se apresenta como um sistema de trincas no vidrado. Este defeito é oriundo de tensões de tração no vidrado, que à medida que aumentam provocam sistemas de trincas cada vez mais finos. O gretamento pode se manifestar de diferentes formas. A maioria das vezes chega até a superfície em forma de pequenas fissuras ..., outras vezes, as fissuras permanecem ocultas dentro da interface suporte-esmalte sem chegar à superfície (MENESES, CAMPOS, NEVES \& FERREIRA 2006: 2).

O gretamento pode ser subdividido em gretamento imediato e retardado: o primeiro surge quando "o vidrado a temperatura ambiente é tracionado pelo suporte a ponto de ocorrer o aparecimento de trincas, sendo observado logo após a saída do forno ou pouco tempo depois"; o segundo "ocorre quando da deformação sofrida pelo biscoito devido à umidade adsorvida" (MENESES, CAMPOS, NEVES \& FERREIRA 2006: 2). Portanto, o que vemos nas faianças finas de unidades domésticas é, provavelmente, o gretamento retardado causado pela expansão por umidade (EPU) - em inglês moisture expansion (ME). EPU é o "termo técnico utilizado para designar a expansão sofrida por materiais cerâmicos quando em contato com a água na forma líquida ou de vapor. Essa expansão geralmente ocorre lentamente e é relativamente pequena. Mesmo assim pode levar ao gretamento de peças esmaltadas e ao comprometimento estrutural dos corpos cerâmicos (MENESES, CAMPOS, NEVES \& FERREIRA 2006: 1).

Desta maneira, quando há contato entre a pasta, o biscoito, das louças, e o ambiente (como quando o processo de esmaltação deixa um aro em vidrado na base ou na boca das 
peças), a mesma absorve umidade que causa alteração na dimensão do corpo cerâmico, que se expande. Esta absorção tem a ver com a porosidade do corpo cerâmico e, no caso, sabe-se que os biscoitos das faianças finas são bastante porosos - "a capacidade de absorção de água de uma peça cerâmica fornece um indicativo da porosidade aberta do produto, ou seja, o volume total de poros comunicados com o exterior e susceptíveis de serem preenchidos com um fluido à pressão atmosférica" (MENESES, CAMPOS, NEVES \& FERREIRA 2006: 11). Uma vez que o coeficiente de expansão do vidrado é inferior ao da cerâmica, mais plástica, o vidrado racha, criando trincas ou fissuras no mesmo. A alta taxa de chumbo dos vidrados plúmbeos dá origem a valores menores de expansão e de coeficientes de contração durante o resfriamento (KINGERY \&VANDIVER 1986: 267), menos propensos a apresentar fissuras do que vidrados mais alcalinos.

A análise da presença ou ausência do gretamento nas peças do sítio Petybon possibilitou perceber uma correlação entre o fato do vidrado cobrir toda a superfície da peça em faianças finas e nestas peças não haver fissuras no vidrado - o contrário também sendo averiguado. Peças rachadas, com biscoito aparente, estavam gretadas. Em 627 das peças vidradas da amostra composta pelas coleções IPHAN, MAE e NAUBC o gretamento estava ausente.

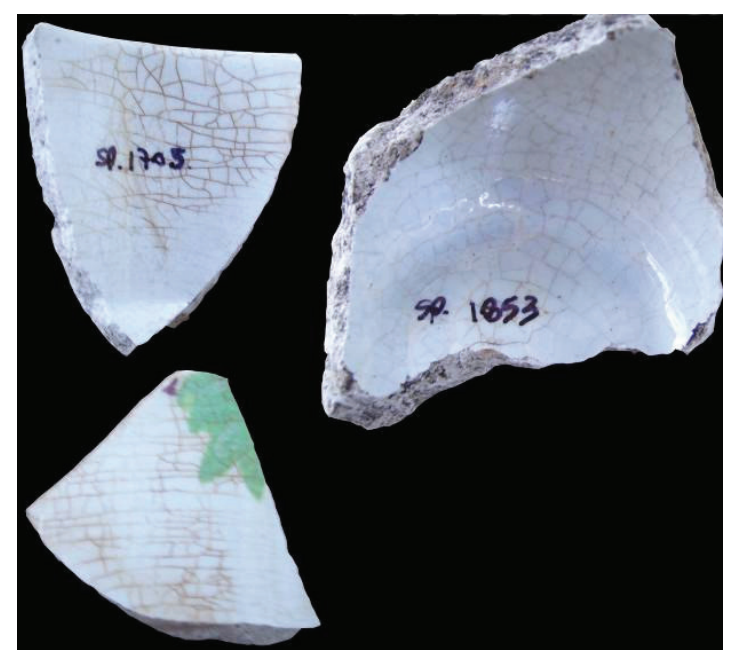

Exemplo de gretamento nos esmaltes de fragmentos de louças do sítio Petybon. No caso, como não foram consumidas, as trincas no vidrado estão amarronzadas pela penetração de terra.

\section{I) $\underline{\text { Marcas }}$}

As marcas, ou selos, são os símbolos existentes, sempre no fundo das peças, que designam o fabricante, não necessariamente presentes em todas os vasilhames. Segundo 
Ramsey, nem todas as louças fabricadas por uma fábrica ganham marcas (RAMSEY apud WORTHY 1982: 342). E isto pode ocorrer por diversos motivos: a não necessidade de marcar as peças, o desejo de grandes lojas, como Mappin, de possuírem louças com um selo próprio, etc.

A coleção analisada apresentou 21 tipos de marcas, sendo incluídas nestas tipologias não apenas seus formatos e designs, como também as variantes de cor. As marcas na tabela abaixo não estão em nenhuma ordem cronológica, seus números apenas indicam a ordem na qual foram sendo diagnosticadas durante a análise.

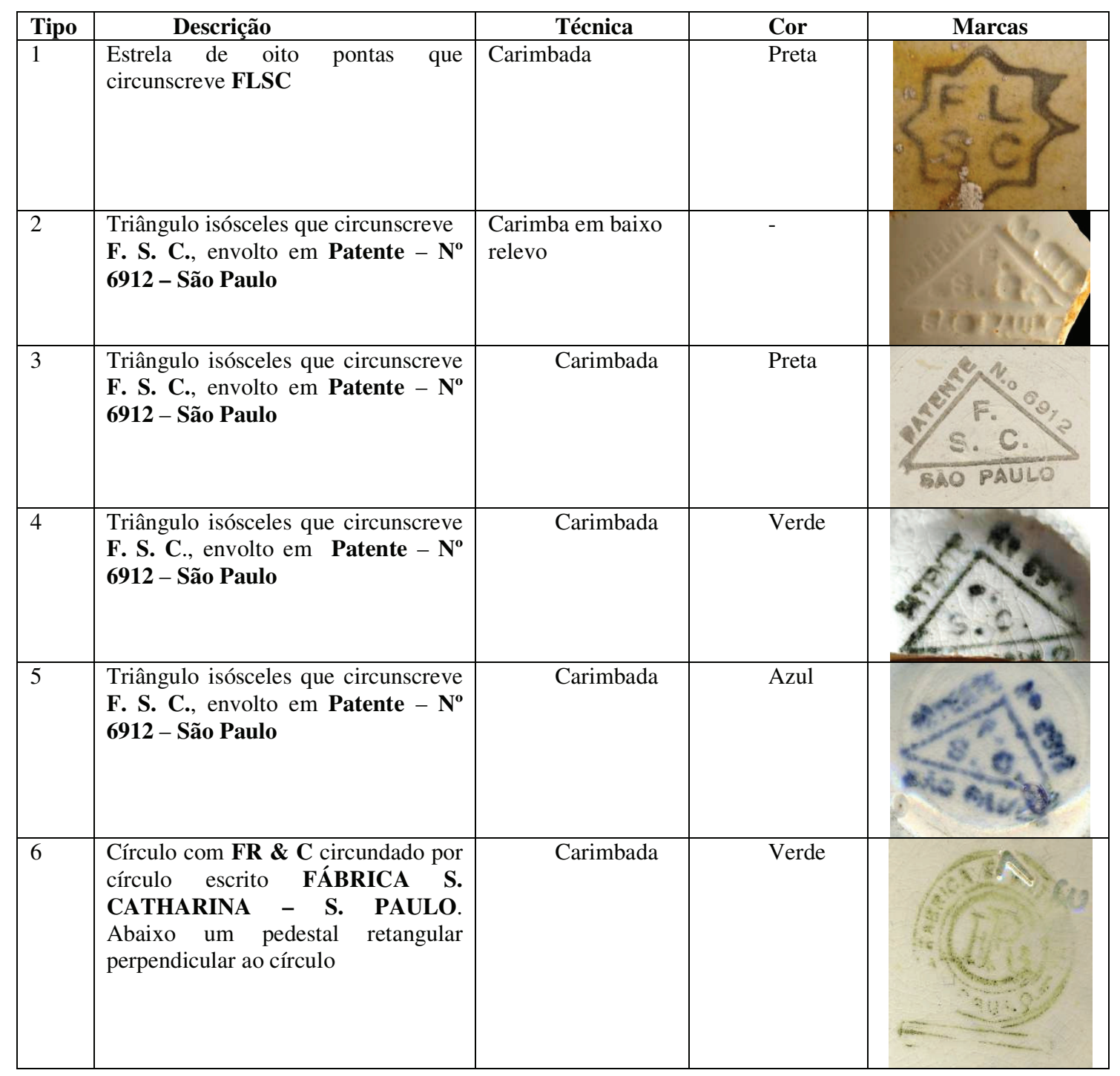




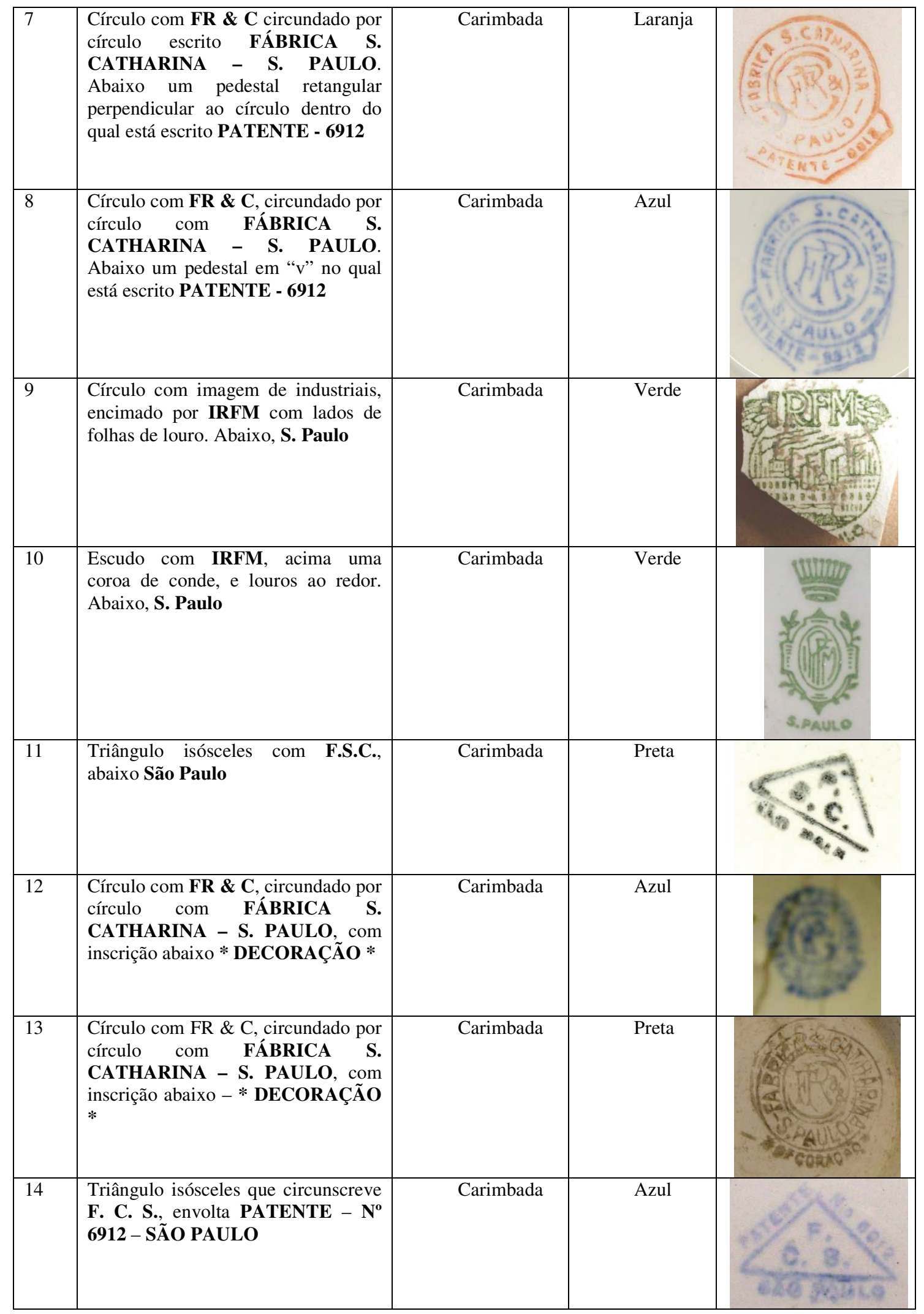




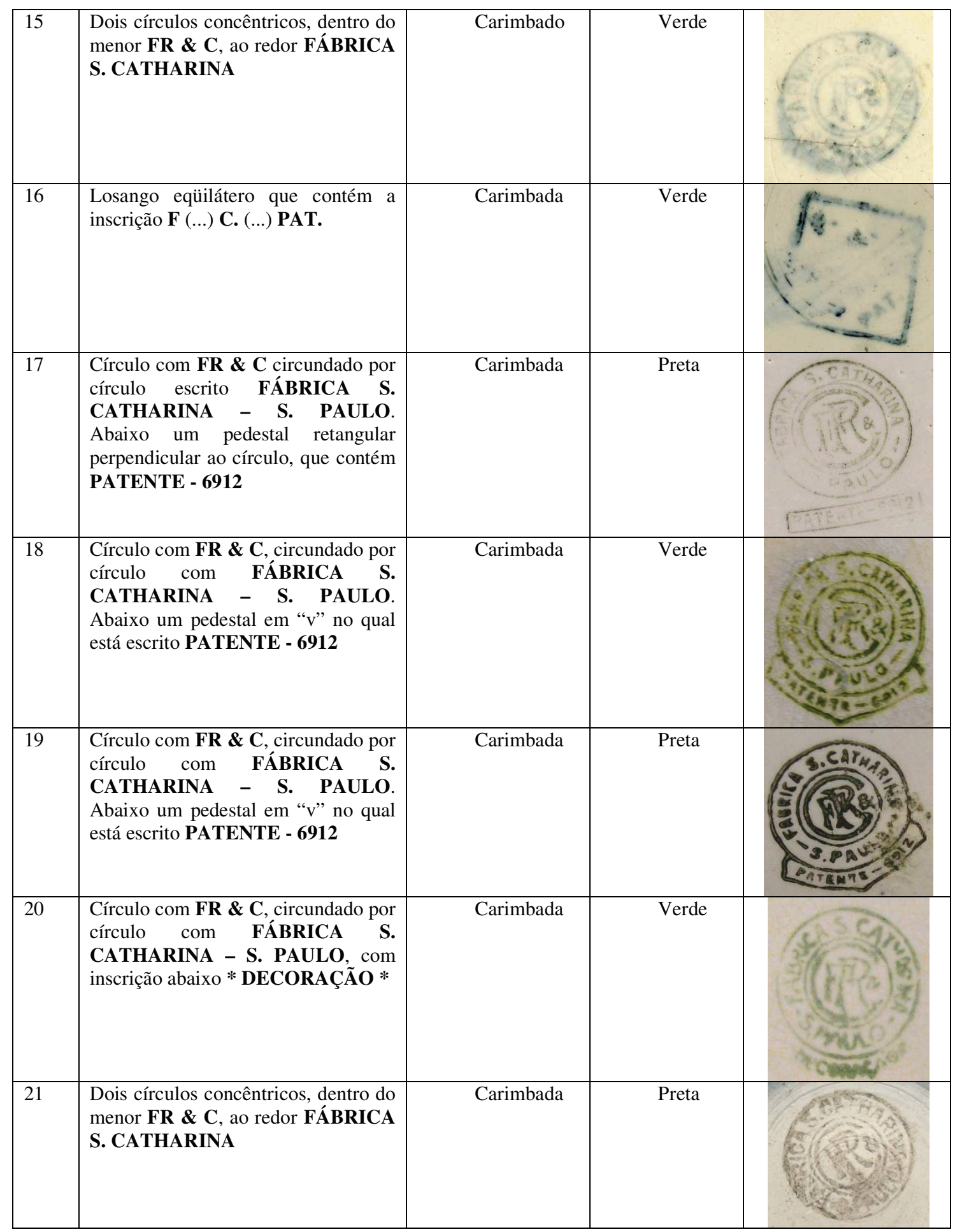

A época da Santa Catharina possui a maior parte das variantes de marcas, ficando a época dos Matarazzo apenas com duas variantes, isto porque se sabe que as IRFM possuíam uma marca única para seus produtos, a marca 9 , que aparece em indústrias químicas, cerâmicas e de 
alimentos, conectando todos os produtos dos quais eram donos. Apesar disso, a complexidade dos elementos é maior nas marcas da IRFM (louros, brasão, coroa, fábricas) do que na época da Santa Catharina, cujas marcas, muito mais simples, em geral configuram-se por formas geométricas (círculos, triângulos, losangos, retângulos e um octógono regular representado por uma estrela de oito pontas). Ressalva seja feita também à marca 14 que só aparece em azul, trazendo a inscrição F. C. S. (ao invés do correto F. S. C.), que pode ter sido um engano na fabricação do carimbo, gerando um defeito visto apenas após a segunda queima. As marcas que contêm a inscrição FR \& C se referem à sociedade Fagundes, Ranzini e Cia.

A marca 10 é um brasão com a coroa do conde, representando o Conde Matarazzo. As coroas são um dos mais antigos símbolos de soberania e nobreza e a IRFM as uniu aos simbólicos louro e brasão na configuração de marcas que demonstravam a força e o poder do grupo; mas, diferente de uma "nobreza" consuetudinária ou hereditária, os Matarazzo justamente colocavam o desenho de suas fábricas justamente para indicar essa nova forma de aquisição de poder, a econômica (via indústria). A coroa representada na marca 10 é a coroa do conde utilizada apenas pelas realezas da Rússia, Brasil, Portugal, Alemanha, França e Espanha, representada com nove pérolas (a coroa de conde, enquanto objeto tridimensional, possui 16 pérolas, vendo-se apenas 9 na sua representação frontal em duas dimensões).

O total do sítio Petybon possui apenas $10 \%$ de louças com marca. $\mathrm{Na}$ amostra analisada das coleções IPHAN, MAE e NAUBC, 511 peças contêm marcas, com predominância das marcas tipo 3, 5 e 11 (todas da época da Santa Catharina e todos em forma triangular).

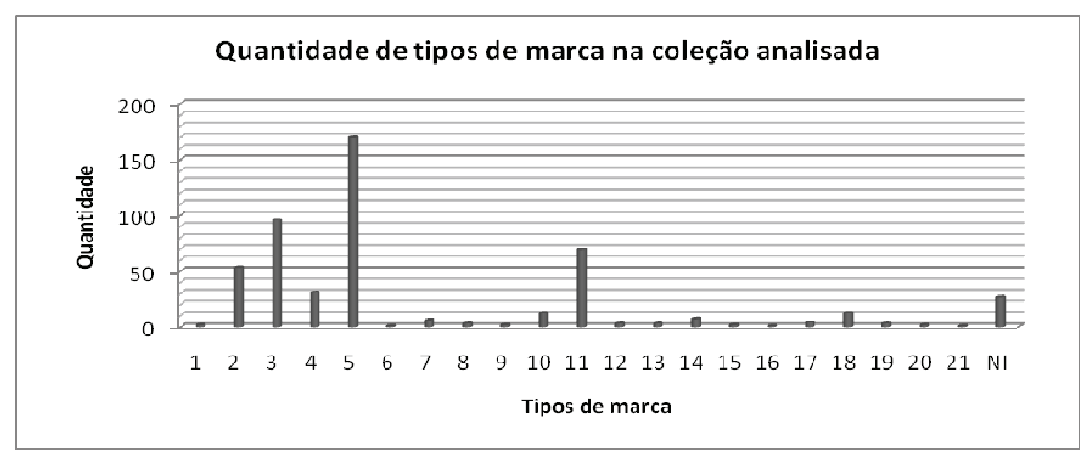

Procurei também perceber se havia alguma especialização das marcas por categoria funcional. $\mathrm{O}$ que ocorreu foi que algumas marcas são específicas de determinadas formas: a categoria funcional 1 e 2, as malgas/tigelas e as xícaras, têm predomínio das marcas 3 e 11, que não aparecem mais em nenhuma outra categoria, com exceção das canecas (categoria funcional 3), nas quais as marcas predominantes são 3 e 4 . Para os recipientes abertos, os pratos têm 
predomínio das marcas 2 e 17 e os pires, 2 e 10, marcas que, praticamente ou completamente, estão ausentes das categorias funcionais 1,2 e 3 . Nas demais categorias, as únicas marcas presentes são a 4 e a 11. Como as marcas 3, 4 e 5 são iguais em design mas diferentes em cor, acredito haver uma separação também por coloração entre marcas e formas: preta para malgas, azul para xícaras, azul e verde para canecas, e em baixo relevo para os pratos e pires.
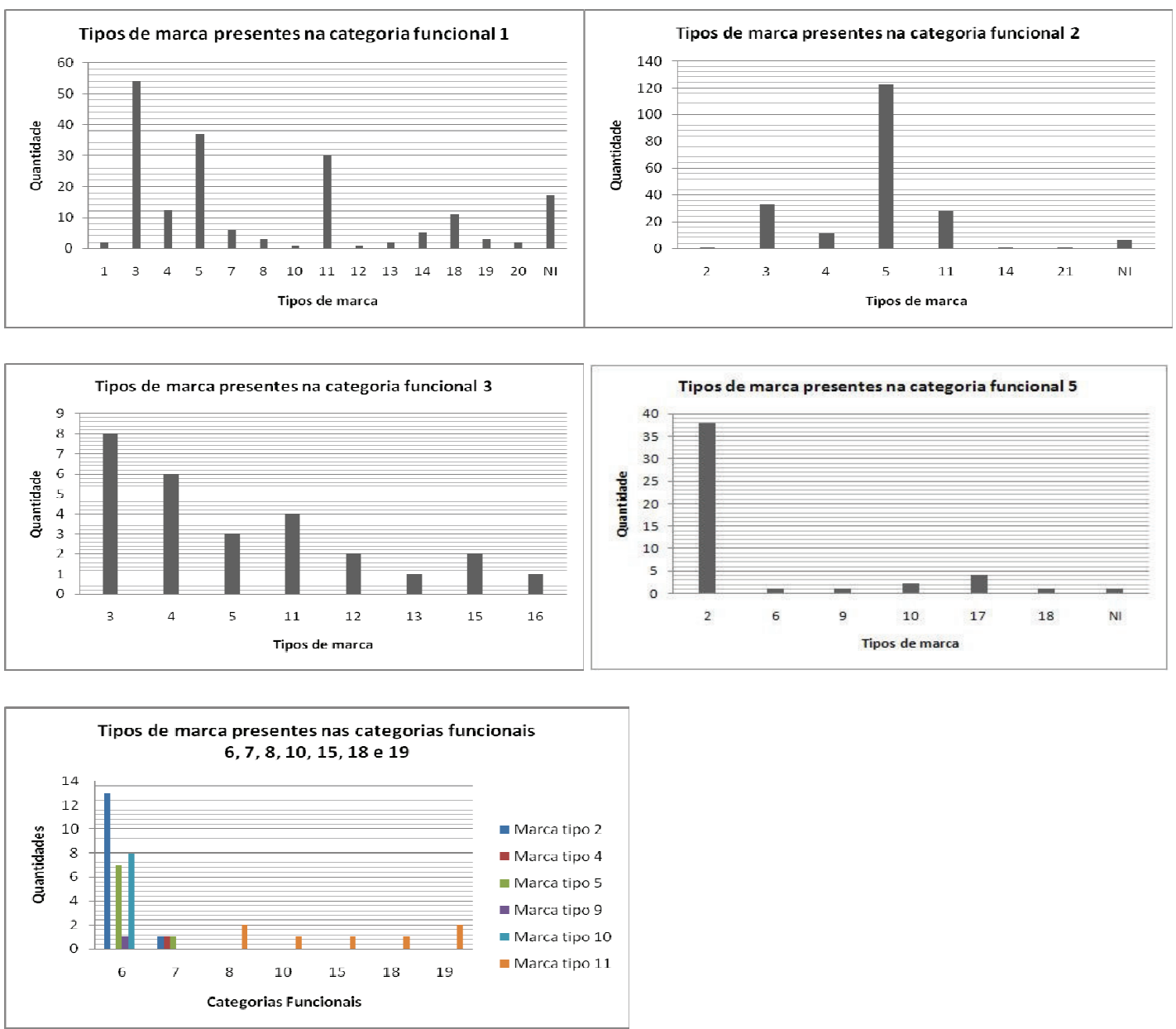

Abaixo, seguem os desenhos básicos das marcas, às quais tentei pressupor uma ordem cronológica de acordo com a complexificação de seus elementos, assim como pela mudança dos proprietários. O intervalo de produção que as marcas definem já é bastante restrito, 19131937, sendo que tudo referente à Santa Catharina vai apenas do período de 1913 a 1926 e as duas últimas marcas do período de 1927 a 1937. Assim, acredito que a primeira e a segunda marca são mais antigas; as triangulares e a losangular fazem parte de um segundo momento; as próximas cinco marcas de um terceiro momento, que é sucedido então pelas marcas dos 
Matarazzo. Isso não implica numa impossível coexistência entre as marcas da época da Santa Catharina

Os decalques que fiz das marcas baseiam-se no que se podia ver nos artefatos arqueológicos. Algumas, por exemplo, como a marca em losango, estão borradas e preferi não inferir qual era a inscrição que continha. A segunda marca, depois da estrela de oito pontas, não foi encontrada no sítio, mas a adicionei porque faz parte das marcas da Fábrica e pode ser encontrada em sítios arqueológicos (como o foi, em unidades domésticas [BORNAL \& QUEIRÓS 2006]). Essa marca contém, além da estrela da Santa Catharina, dois leões, que podem indicar uma inspiração em marcas européias. Pode ser encontrada tanto em carimbo pintado como em baixo relevo (CARVALHO 2008):
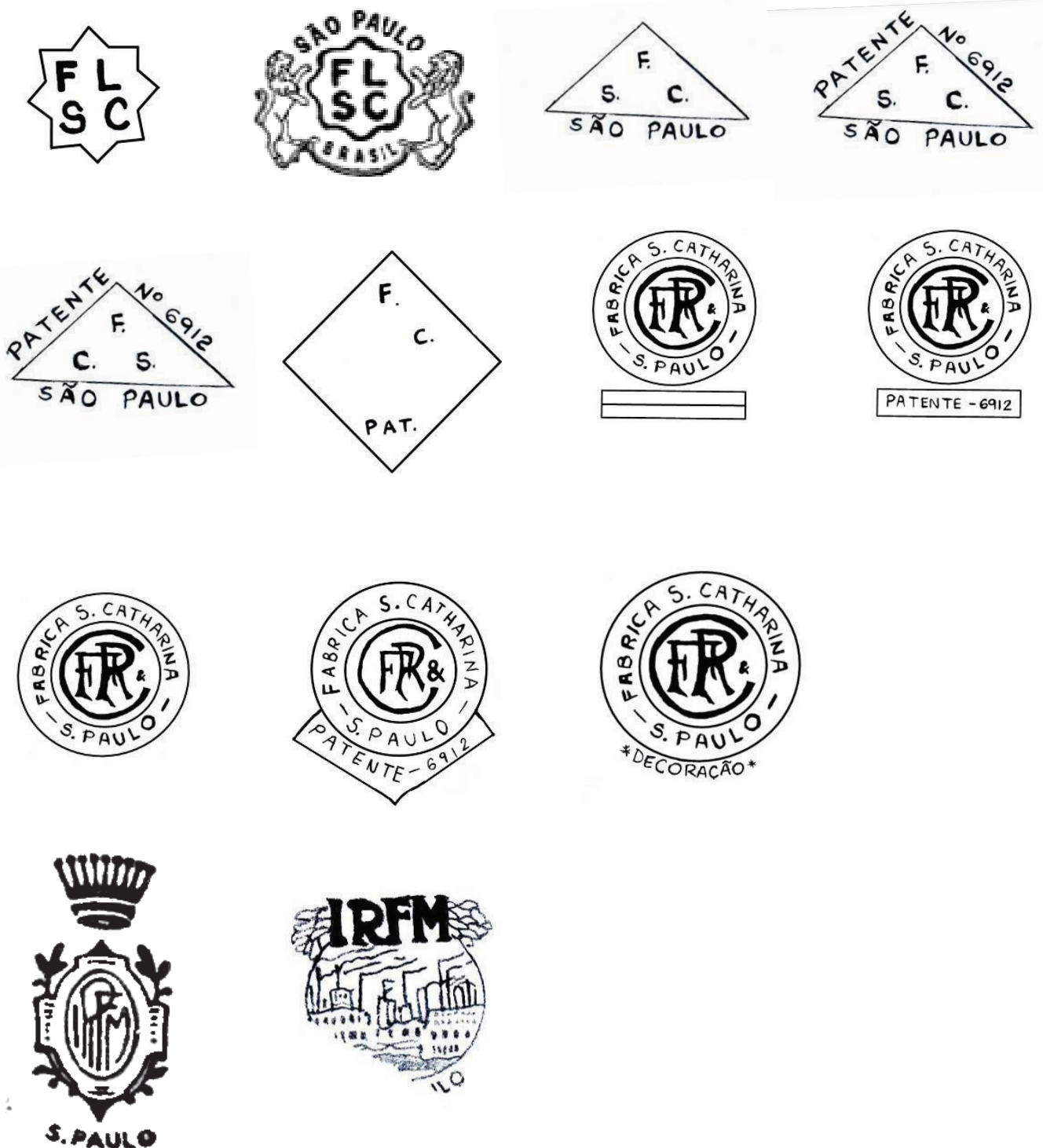


\section{Mobiliário do Forno ou Cerâmica de Olaria}

Mobiliário do forno ou "cerâmica de olaria" (BUGALHÃO, SOUZA \& GOMES 2004), em inglês kiln furniture, são artefatos produzidos para organizar as peças a serem queimadas, facilitar a queima e resolver problemas internos ao forno. Ao que parece, todas as produções cerâmicas com fornos fechados possuem algum tipo de mobiliário. É interessante também perceber que parece existir uma certa tradição quanto à forma dos mesmos, um equilíbrio entre forma e função que resultou em designs e performances destes artefatos que foram, quase que de modo inquestionável, adotados por inúmeras olarias e fábricas ao longo de muito tempo.

No sítio Petybon, o mobiliário do forno é composto por cones pirométricos, apoiadores, cravilhos, trempes, caixas refratárias e os moldes de gesso utilizados na colagem.

\section{A) $\quad$ Cones Pirométricos}

Cones pirométricos são os dispositivos utilizados para calibrar o calor durante a queima de materiais cerâmicos. Os cones, usados, freqüentemente, em jogos de três, são posicionados nos fornos junto das cerâmicas a serem queimadas e fornecem uma indicação visual de quando os objetos alcançaram um estado de maturidade $x$, uma combinação de tempo e temperatura. Assim, os cones pirométricos dão um equivalente da temperatura, mas não são mecanismos de medição simples. O cone pirométrico é descrito por Dodd e Murfin (1994) como "a pyramid with a triangular base and of a defined shape and size; the "cone" is shaped from a carefully proportioned and uniformly mixed batch of ceramic materials so that when it is heated under stated conditions, it will bend due to softening, the tip of the cone becoming level with the base of a definitive temperature". As séries mais conhecidas são os Cones Seger (Alemanha), Cones Orton (EUA) e os Cones Staffordshire (Reino Unido) (CANOTILHO 2003: 49).

Em 1782, Josiah Wedgwood criou cones pirométricos com maior escala de temperaturas e maior exatidão. O design moderno do cone pirométrico, no entanto, foi desenvolvido pelo técnico em cerâmica, o alemão Hermann Seger, e utilizado pela primeira vez para controlar a queima de porcelanas na Königliche Porzellanmanufaktur, na Berlim de 1886. Os cones eram, usualmente, feitos de material cerâmico e em forma de pirâmide triangular alongada, medindo aproximadamente $7 \mathrm{~cm}$ de altura. Seu funcionamento ocorria da seguinte forma: depois de se optar pela temperatura que se pretendia atingir, escolhia-se o cone correspondente a essa temperatura (cones vendidos comercialmente têm uma numeração a que corresponde uma 
temperatura de fusão). Eram postos, então, perto de uma abertura de observação do forno. Quando o forno atingia uma temperatura, prefixada, o cone inclinava-se completamente tocando, com a ponta, a prateleira em que estava localizado. O cone deve ser colocado em uma determinada posição que permita ser observado pelo ceramista através de um visor, que normalmente situa-se na porta do forno (CANOTILHO 2003: 49). No sítio Petybon, os cones não possuíam nenhuma numeração indicando um possível código para temperatura. Também não foi possível saber se os cones eram fabricados no estrangeiro ou na própria fábrica.

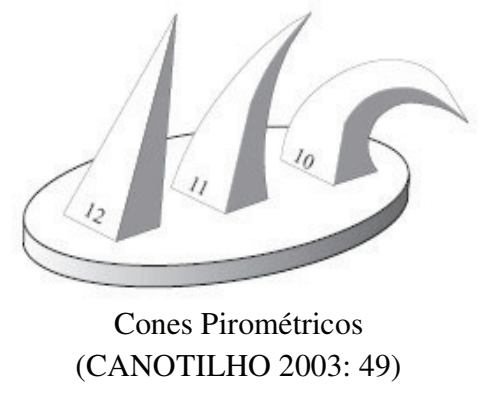

É interessante lembrar que desde a antiguidade, até o aparecimento da eletricidade e do forno elétrico, a medição da temperatura não se baseava numa medição precisa, fruto de qualquer equipamento. A temperatura era medida através da recolha de amostras ou pela cor interior do forno. Esta operação era e é executada nas últimas fases da cozedura, permitindo uma análise visual e baseada sempre na grande experiência do enfornador. Este processo empírico era, geralmente, complementado com a observação direta da cor interior do forno (assim é o processo na Porcelana Monte Sião atualmente). Somente no final do século XIX, portanto, com fornos mais comerciais, é que os cones pirométricos se tornaram, sem dúvida, o método mais popular para determinar a temperatura no interior de um forno que não tem qualquer tipo de sistema de controle (como algum termostato).

A coleção analisada é composta por 123 cones pirométricos, mas apenas um cone com marcas de utilização [figura 3 abaixo]), a maior parte deles anexado a uma base de argila refratária. Somente mais tarde seriam inventados os cones com base para seu auto-suporte (self-suporting cones), sem a necessidade de fixá-los sobre uma base de argila, eliminando alguns possíveis erros decorrentes de sua montagem e posicionamento mal feitos. 

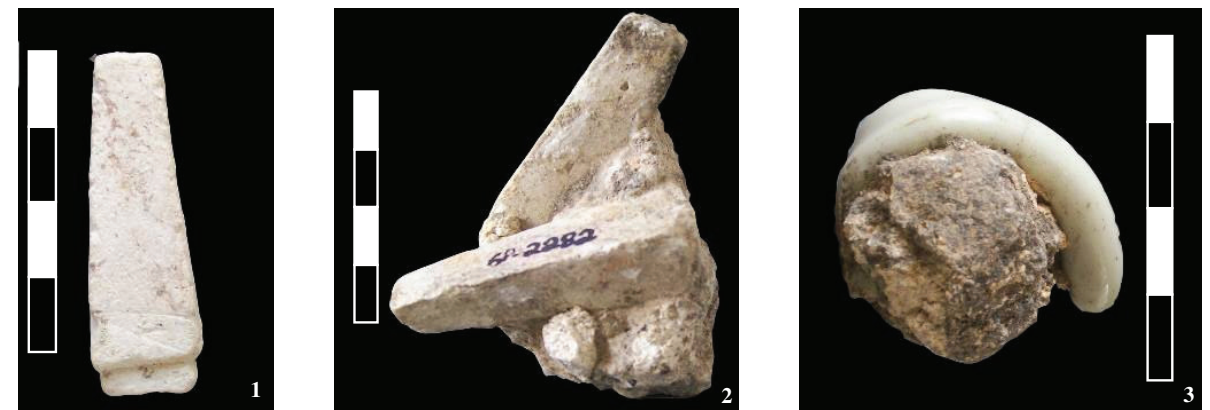

1 - Cone pirométrico

2 - Cones pirométricos apoiados sobre base de cerâmica refratária, ainda não utilizado.

3 - Cone pirométrico apoiado sobre base de cerâmica refratária depois de utilizado.

\section{B) $\quad \underline{\text { Trempes }}$}

A definição de "trempe" é bastante ampla. De "trempes" também eram as estruturas com três pedras que apoiavam panelas ou tachos para cozinhar, as estruturas metálicas sobre as quais colocamos hoje nossas panelas nos fogões, e não necessariamente têm sempre uma estrutura tri-partida. Segundo o Houaiss (2001) o termo surgiu por volta do século XIV para designar o aro de ferro com três pés usado para apoiar panelas sobre o fogo, sinônimo, às vezes, de tripé. Portanto, destarte sua mesma função, poderia estar se referindo tanto a materiais em pedra, como em ferro ou cerâmica.

José de Alencar em Til, romance de 1872, narrando os arredores de Santa Bárbara, no estado de São Paulo, referindo-se a um casebre e depois a uma venda de beira de estrada, escreve:

[...] fervia a panela posta em uma trempe de pedra no meio do chão. (ALENCAR 1965: 110)

- Nhanica![...] Coa um bocado de café! Ergueu-se então a rapariga [...] tirou da trempe a panela de feijão para deitar o boião d'água; e arranjando o saco [...] correu a buscar água [...] (ALENCAR 1965: 112)

E referindo-se à casa de um plantador de cacau nos arredores de Óbidos, no Pará, o viajante Henry Walter Bates, em meados do século XIX, testemunha o uso de uma trempe de barro:

Os utensílios domésticos - jarros de barro, quartinhas e caçarolas - estavam no chão, em uma 
extremidade, perto do fogo de lenha, com um bule de café fervendo em trempe de barro. (BATES 1944: 296)

Nos Inventários e Testamentos arrolados para São Paulo, do século XVII, constam "trempe de ferro" (Inventário de Izabel Mendes, 1633) e "3 trempes de ferro" (Inventário de Maria Tenória, 1620). Nos Autos da Inconfidência Mineira, do final do século XVIII, muitos dos testamentos contêm, dentre os bens arrolados, "trempe de ferro de 3 fogos" (Inventário de Cônego Luís Vieira da Silva, 1789-1791), "trempe grande de ferro com três pés" (Inventário de José Ayres Gomes, 1791).

No entanto, para a indústria cerâmica a trempe tem um significado mais preciso, não obstante sua função de apoiador ser basicamente a mesma. Assim, as trempes, ou "pés de galinha", são peças em faiança fina com forma estrelada, com 3 pontas, que serviam como suporte dos recipientes côncavos, como xícaras, malgas e canecas. "A trempe era um objecto estrelar de três braços e terminal dobrado em unha, feito à forma. As trempes serviam, conforme os seus tamanhos, para a base das peças vidradas a enfornar" (FERNANDES 1993: 100). Deste modo, são usadas para impedir que a superfície vidrada de objetos cerâmicos entre em contato com a superfície das caixas refratárias ou com o interior do forno durante a queima. Portanto, o uso das trempes não é necessário quando a parte inferior da peça não é vidrada.

Deixam na base dos vasilhames três pequenas marcas onde o vidrado aderia, ligeiramente, aos três únicos pontos do apoiador que tocavam a peça. Segundo Bockol (1995: 47), as trempes eram fabricadas para serem utilizadas com o terminal dobrado em unha voltado para a base da peça; eles permitiam que as peças fossem empilhadas, de modo que somente ficassem três pequenos pontos no vidrado na base. Além disso, a utilização da trempe possibilitava a não retirada do vidrado da base ou da borda da peça, não deixando qualquer possibilidade para o biscoito aparente, diminuindo as possibilidades de gretamento.
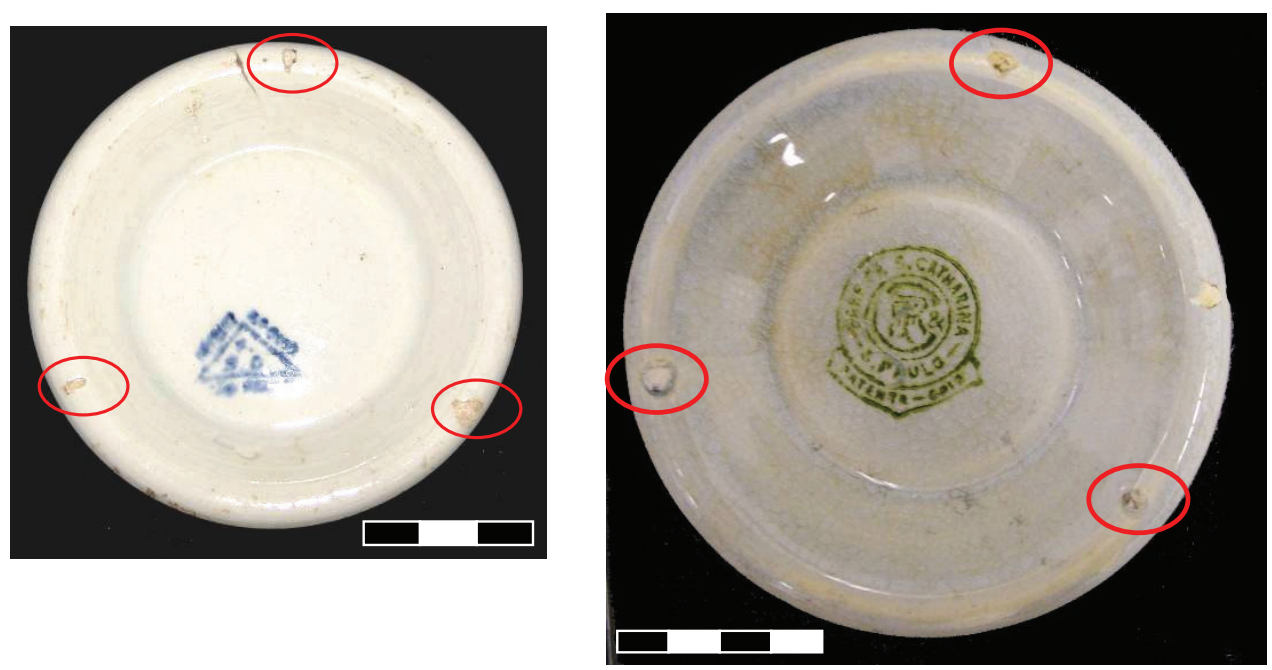
As escavações realizadas na fábrica de louças de Coalport, levadas a cabo por Barker e Horton, entre 1991 e 1995, localizaram as mesmas formas de apoiadores, tanto as trempes (silts ou spurs), quanto os apoiadores de corpo prismático triangular (saggar pins), ambos feitos em faiança fina creamware (BARKER \& HORTON 1999). As escavações no Mandarim Chinês, região da baixa Lisboa, entre 1991 e 1996, identificou um conjunto de fornos de produção cerâmica referentes a uma olaria de cerâmica vidrada e não vidrada, de cronologia islâmica (final do século X-século XII), que gerou uma coleção na qual a maior parte dos artefatos são "cerâmicas de olaria", ou seja, trempes e o que foi chamado "barras" (BUGALHÃO, SOUSA \& GOMES 2004). A coleção contida no IPHAN-RS referente aos trabalhos de escavação em locais de Missões Jesuíticas contém um fragmento de trempe pertencente ao sítio São Lourenço Mártir, no município de São Luiz Gonzaga/RS, local de antiga missão fundada em 1690 pelo Padre Bernardo de la Vega, com população proveniente da redução Argentina de Santa Maria (ZANETTINI ARQUEOLOGIA 2008). No Convento de São Miguel das Gaeiras, freguesia do Concelho de Óbidos, em Portugal, a presença franciscana legou também trempes associadas a trabalhos na olaria, concomitante a localização de antigo forno para cerâmica vidrada durante as intervenções para restauração do convento na década de 1990.

A recorrência destas formas, em outras fábricas e contextos produtivos oleiros, parece apontar para uma bem sucedida relação entre forma e função na tecnologia destes artefatos. Ao que parece, uma vez descobertos, foram utilizados por contextos variados, dentro do repertório de produção cerâmica, sempre com pequenas nuances em suas morfologias.

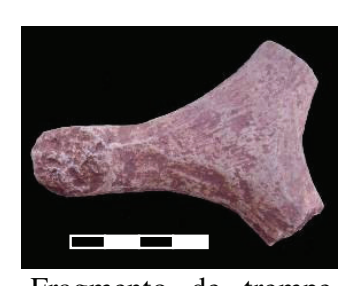

Fragmento de trempe do sítio arqueológico São Lourenço Mártir, RS, século XVII-XVIII

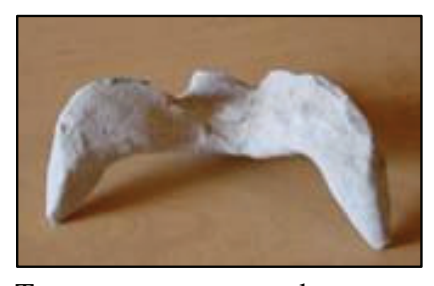

Trempe encontrada no Convento de São Miguel das Gaeiras, freguesia do Concelho de Óbidos, Portugal, séculos XVII-XVIII

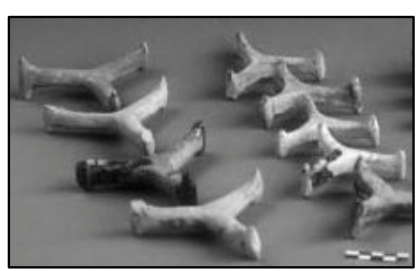

Trempes da olaria islâmica do Mandarim Chinês, Lisboa, Portugal, séculos X-XII.

O sítio Petybon possui 1266 separadores, dentre trempes, cravilhos, etc. Na amostra composta pelas coleções IPHAN, MAE e NAUBC foram localizadas 19 trempes, a maior parte delas sem vidrado, em tamanhos variados. A presença do vidrado em algumas das trempes pode ser explicada, talvez, pela natural volatilização do mesmo durante a queima. 

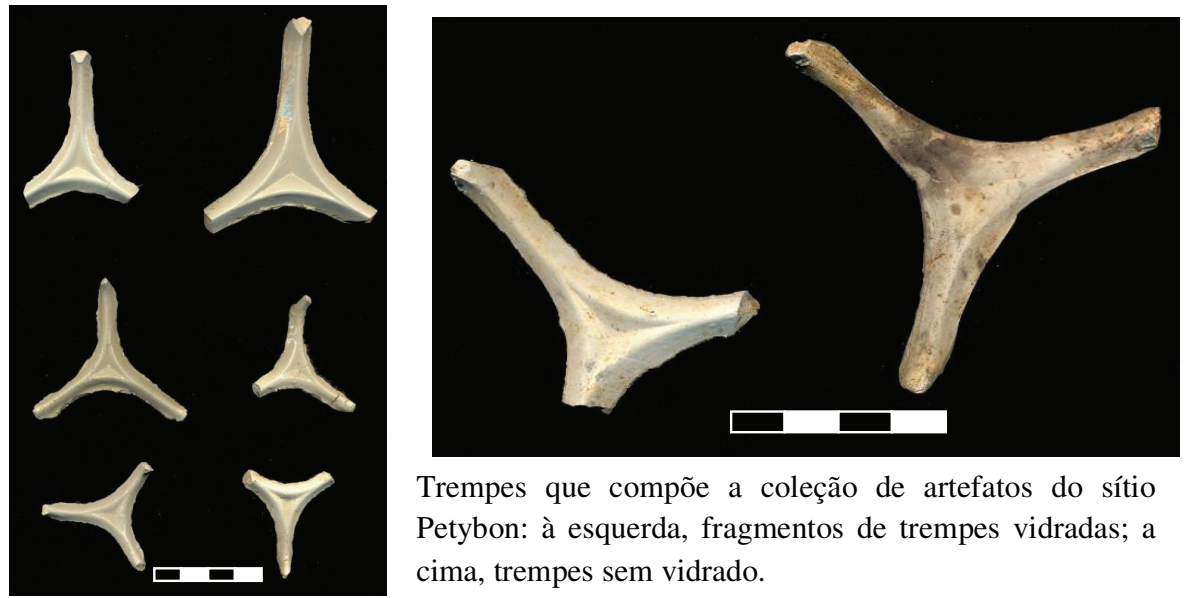

Trempes que compõe a coleção de artefatos do sítio Petybon: à esquerda, fragmentos de trempes vidradas; a cima, trempes sem vidrado.

A imagem abaixo é desenho esquemático que mostra a utilização de trempes e apoiadores durante a queima de louças em faiança fina. A primeira apresenta o desenho de um forno elétrico para cerâmica, utilizado para louças, com seu mobiliário: além de cones pirométricos e alguns moldes de gesso, vê-se a presença dos apoiadores e separadores, com forma semelhante aqueles encontrados no sítio Petybon.

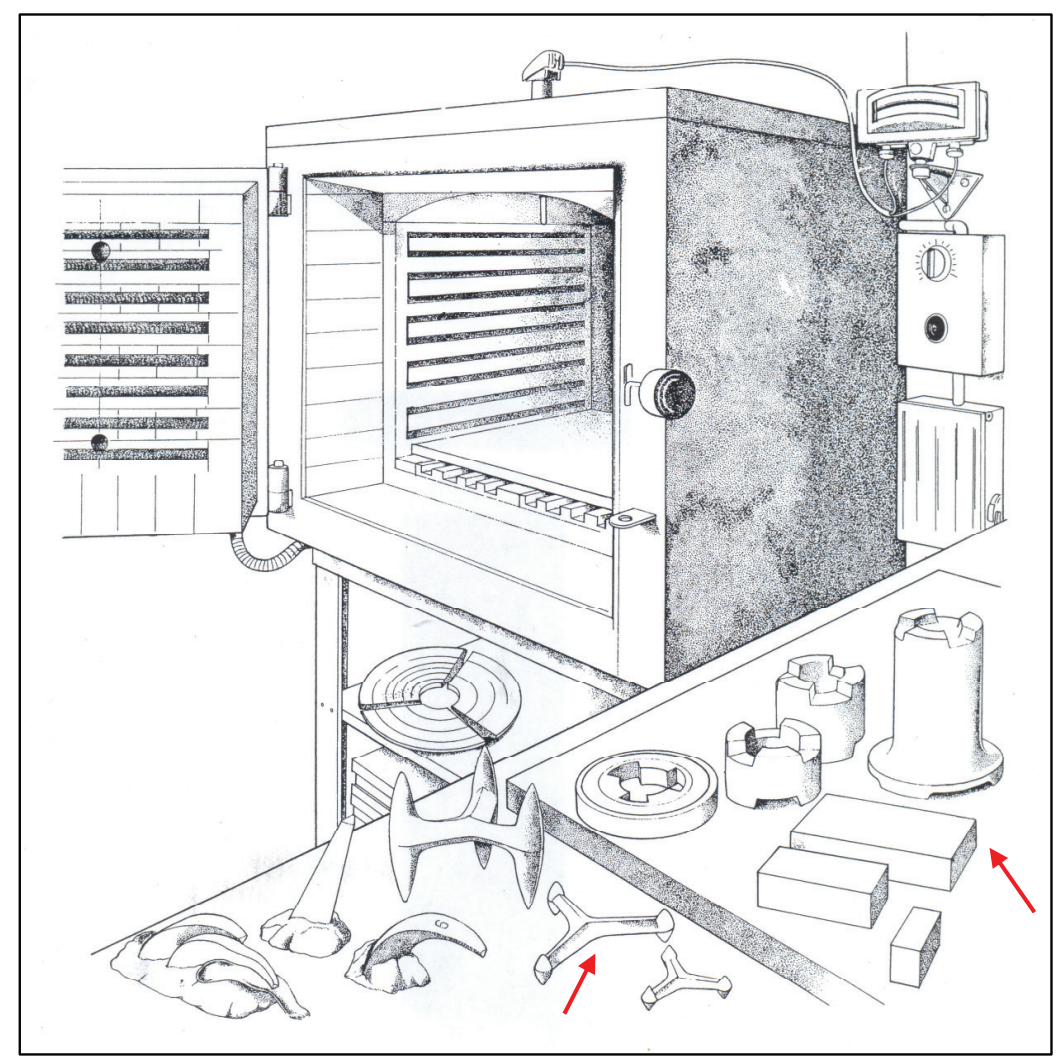

Mobiliário do forno segundo GWILYM (1973: 63). Vemos o uso de trempes e apoiadores na forma de barras prismáticas. No canto a esquerda, cones pirométricos. 


\section{C) $\quad$ Cravilhos}

Cravilho, cravilha ou cavilha, são os artefatos com corpo em forma de prisma retangular com uma fileira de "dentes" para apoio de abas, ligados à fabricação de pratos e outros recipientes abertos como travessas. Acredito que o uso era semelhante ao da peça do desenho esquemático apresentado por Bockol (1995), a seguir, que chama de thimble. Segundo Fernandes (1993: 100), o cravilho é uma barra prismática feita com uma seringa rudimentar, causador de muitos pratos apresentarem defeitos na parte externa das abas. Brancante (1981: 704) registra ainda o termo no feminino "cravilha", "peça refratária que serve para separar as peças no forno".

A amostra analisada pormenorizadamente do sítio Petybon contém 18 separadores neste formato. Com os cravilhos, as bordas de cada lado do recipiente apoiado entre os dentes eram voltadas para cima para que o separador tocasse somente a parte externa da aba do prato, permitindo que a borda do recipiente ficasse vidrada, suprimindo, igualmente, a necessidade de retirar parte do vidrado da base da peça - já que não eram queimados apoiando-se pela base.

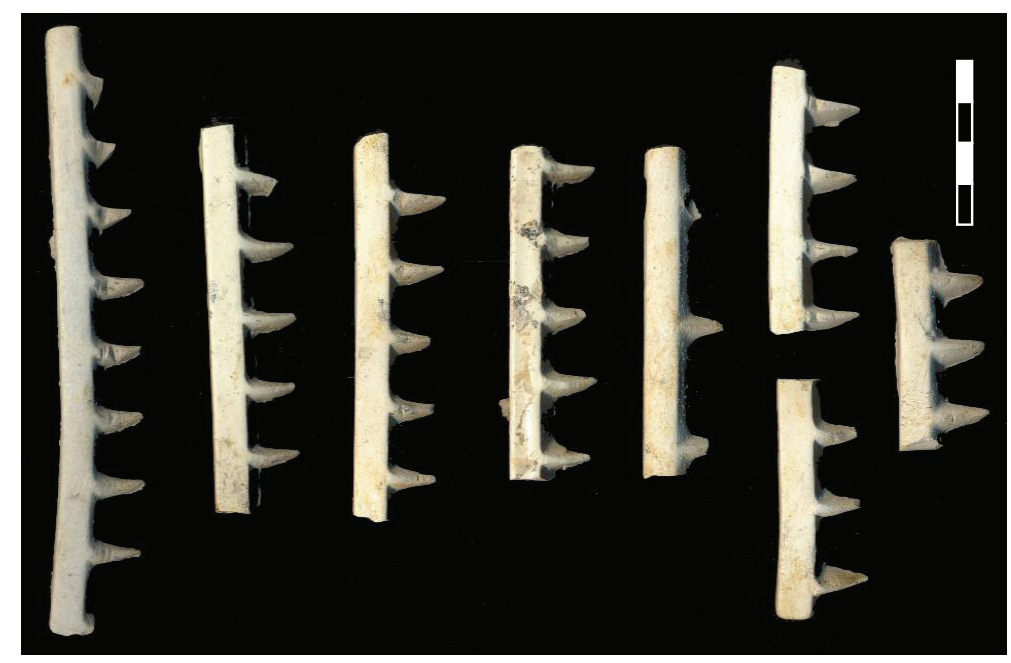



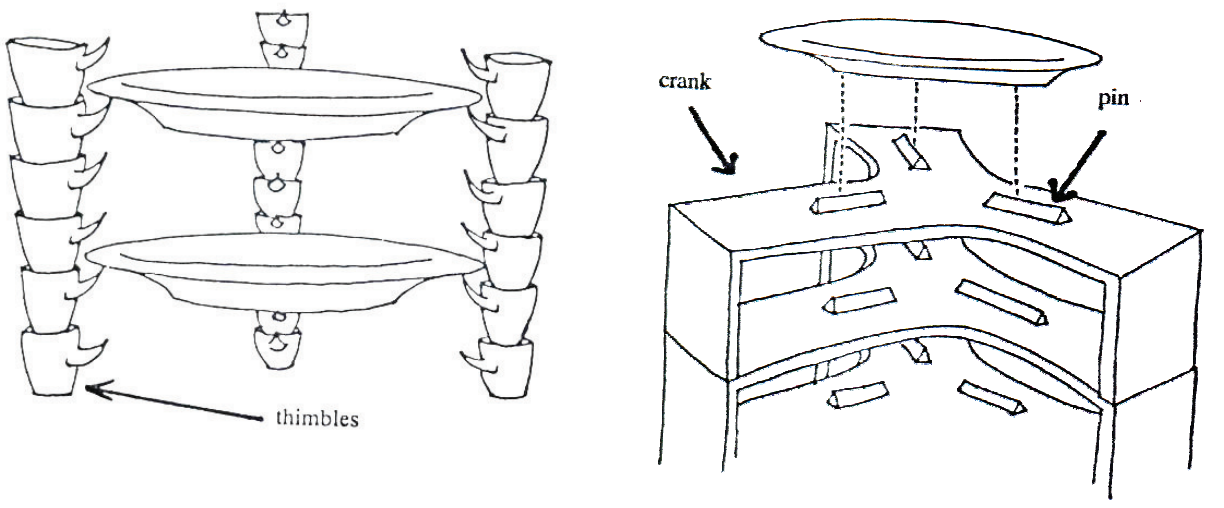

Exemplo do uso dos apoiadores com forma de prisma triangular (pin) e de outros separadores com função semelhante aos cravilhos (thimbles). Adaptado de BOCKOL 1995.

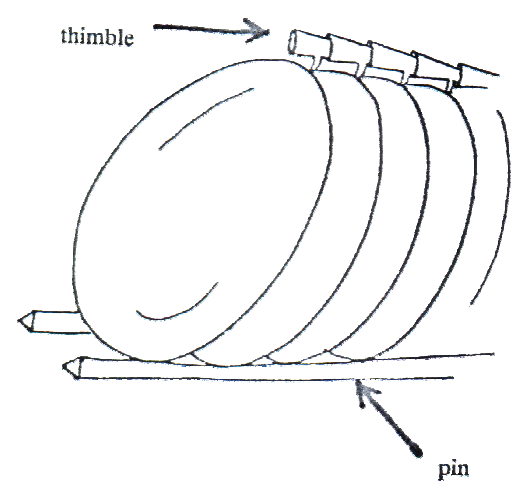

\section{D) Apoiador com canaleta}

É uma peça única com formato retangular, com a presença de uma canaleta em "v" que corta a peça longitudinalmente. Pode-se pressupor que servia também como apoiador devido sua semelhança aos demais apoiadores, mas não há como afirmar com certeza.

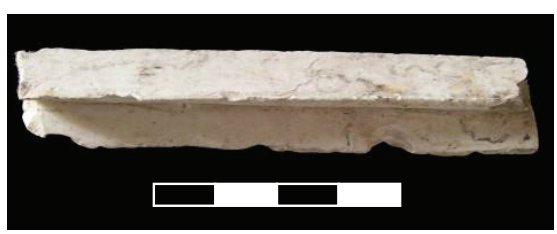

\section{E) Apoiadores em prisma triangular}

Chamo de prisma triangular os apoiadores em forma de prisma, no qual as diretrizes são triangulares compostas por 2 triângulos e 3 retângulos. Alguns destes apresentaram, em uma de suas arestas, diminutas marcas côncavas com maior quantidade de vidrado que podem remeter 
ao ponto de apoio dos lábios dos pratos durante a queima. O uso deveria ser semelhante ao da peça do desenho esquemático apresentado por Bockol (1995), acima, ao qual chama "pin”.

Muito provavelmente estes separadores estavam ligados à fabricação de pratos e outros recipientes abertos como travessas, como pode-se perceber na figura acima. A função pode ser semelhante àquela dos artefatos que Bugalhão, Sousa e Gomes (2004) chamaram "barra" para o mobiliário do forno localizado nas escavações da olaria no Mandarim Chinês em Lisboa.

Desta tipologia de separadores, a amostra da coleção analisada contém 15 peças.

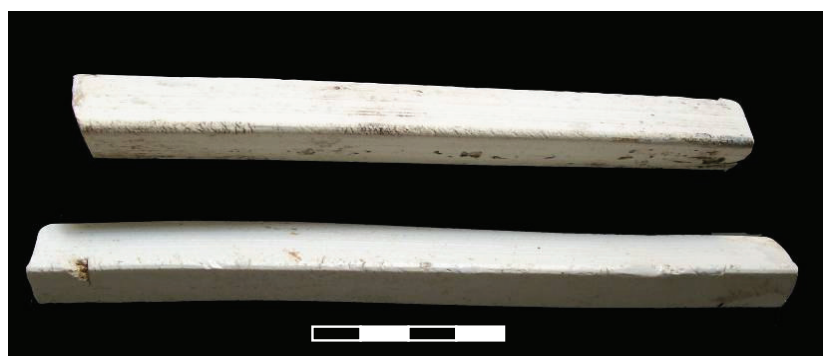

Ao lado apoiadores na forma de prismas triangulares. Abaixo, grupo de apoiadores unidos por alguma alteração ou problema durante a queima.

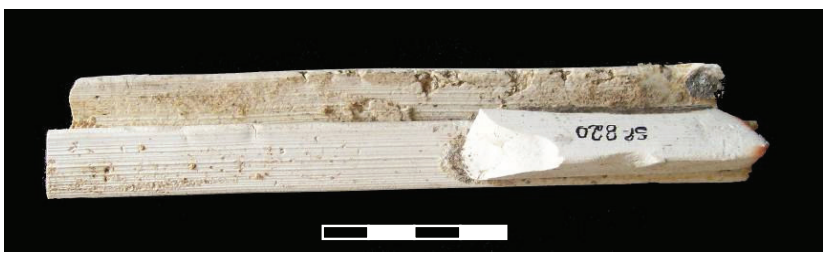

\section{F) $\quad$ Placas e caixas refratárias}

Do total de peças resgatadas do sítio Petybon, 382 peças, inteiras e fragmentadas, conhecidas como "caixas refratárias". Análise pormenorizada foi efetuada em 16 delas, presentes na coleção IPHAN, MAE e NAUBC. Caixas refratárias são recipientes feitos, em geral, no torno, de espessura e granulometria grossas, cuja pasta é, basicamente, composta por chamote, ou seja, um subproduto proveniente de materiais cerâmicos, enquanto rejeito da produção. A fabricação das caixas refratárias é um importante processo suplementar à manufatura de louças, já que todos os artefatos no biscoito ou com vidrado são protegidos por elas (STRATTON 1932: 667). São destinadas a acondicionar as louças durante as queimas, fazendo com que a queima seja mais eficiente, ao mesmo tempo em que protege as cerâmicas em seu interior das chamas diretas e das cinzas no forno (BOCKOL 1995: 47; PILEGGI 1958: 187; KINGERY \& VANDIVER 1986: 265; STRATTON 1932: 667). Dependendo, como mostrei, do tipo de cerâmica e do processo de esmaltação, as peças em seu interior são arrumadas de determinadas formas com ou sem o uso de cerâmicas de olaria. As caixas do sito 
Petybon foram analisadas segundo a pasta, o anti-plástico, as dimensões (altura, diâmetro da boca, diâmetro da base e espessura) e o tratamento de superfície. Aqui, apresentaram como anti-plásticos fragmentos de quartzo bastante grandes, cacos de caixas refratárias, biscoitos e louças moídas.

As caixas são todas feitas de argila refratária. Materiais de argila refratária são aqueles destinados a funções nas quais tem de resistir a longos períodos de aquecimentos ou choques térmicos bruscos (AUN 2000: 69). A pasta, bastante porosa e com grandes poros, serve para uma máxima resistência aos choques térmicos (RYE 1981: 27); a presença da grande quantidade de anti-plástico mineral de grandes proporções, como quartzo, auxilia na condução de calor, já que os minerais são melhores condutores térmicos (MACHADO 2005/2006: 98). O uso do caco moído funciona também como anti-plástico, que tem a facilidade de estar disponível a qualquer momento num universo de produção oleira, eliminando a necessidade de transporte, além de já estar queimado, tornando-se mais estáveis durante as queimas (RYE 1981: 33). Sabe-se, no entanto, que quanto menor os anti-plásticos, maior a resistência aos choques térmicos, inverso do que ocorre na coleção do Petybon, onde está claro que a pasta não passou por um processo tão apurado de moagem nas marombas. Esta menor resistência aos impactos das caixas pode estar associado a pequena preocupação em manter a vida útil desse vasilhame (MACHADO 2005/2006: 100), pois as caixas são refeitas com relativa facilidade. Se as caixas sofrem danos que podem ser reparados, são restauradas com roletes; se não, tornam-se chamote ou são definitivamente descartadas.

Suas superfícies contêm, por vezes, algum tratamento de superfície, como a aplicação de caulim líquido através de um pano, esponja ou brocha, que deixa marcas na parte interna de algumas caixas (presente em 6 peças). $\mathrm{O}$ vidrado na parte externa das bases e em algumas paredes, em suas faces internas, é resultante da precipitação do mesmo durante a queima (presente em 7 peças). Algumas caixas ainda contêm, na parte interna do fundo, fragmentos de quartzo fundidos à superfície refratária (portanto, queimados juntos da caixa ainda crua) que talvez estejam associados a alguma técnica com objetivo de impedir que as peças corressem dentro da caixa, tocando umas nas outras, sem que o trabalhador percebesse, fundindo-se durante a queima e sendo, por conseguinte, descartadas - ou seja, para evitar uma perda na produção (presentes em 6 peças).

Além das caixas, a coleção contém placas refratárias. Placas são artefatos feitos do mesmo material das caixas, argila refratária, que iam ao forno geralmente como tampas. Durante a queima, às caixas se sobrepõem, a base da superior servindo como "tampa" da que 
está embaixo; mas a última caixa da pilha, vai com uma tampa em cima, para vedá-la: a placa. No sítio Petybon as placas tem formato retangular e são representadas por apenas 2 fragmentos.

No caso das caixas, na coleção analisada são representadas por um total de 16 fragmentos e peças inteiras, que se diferenciam entre 4 tipos: elípticas ( 9 peças), circulares ( 1 peça), quadradas (3 peças) e não identificados (3). As peças elípticas são as maiores, geralmente destinadas a peças côncavas (com diâmetro interno de até $31,5 \mathrm{~cm}$ ), com altura variando entre 17 e $20 \mathrm{~cm}$ (6 peças). As peças elípticas com altura entre 9 e $10 \mathrm{~cm}$ (3 peças), e as formas circulares e quadradas, são mais baixas em altura, e, provavelmente, estavam destinadas a conter recipientes planos, como pratos. Quanto à espessura, todas as caixas mantém certa média, sendo as bases mais grossas (variando entre $1,74 \mathrm{~cm} \mathrm{e} 3,23 \mathrm{~cm}$ ) do que as paredes (variando entre $1,38 \mathrm{~cm} \mathrm{e} 2,87 \mathrm{~cm}$ )

Abaixo, imagens das pastas das caixas refratárias e, a seguir, das caixas inteiras.
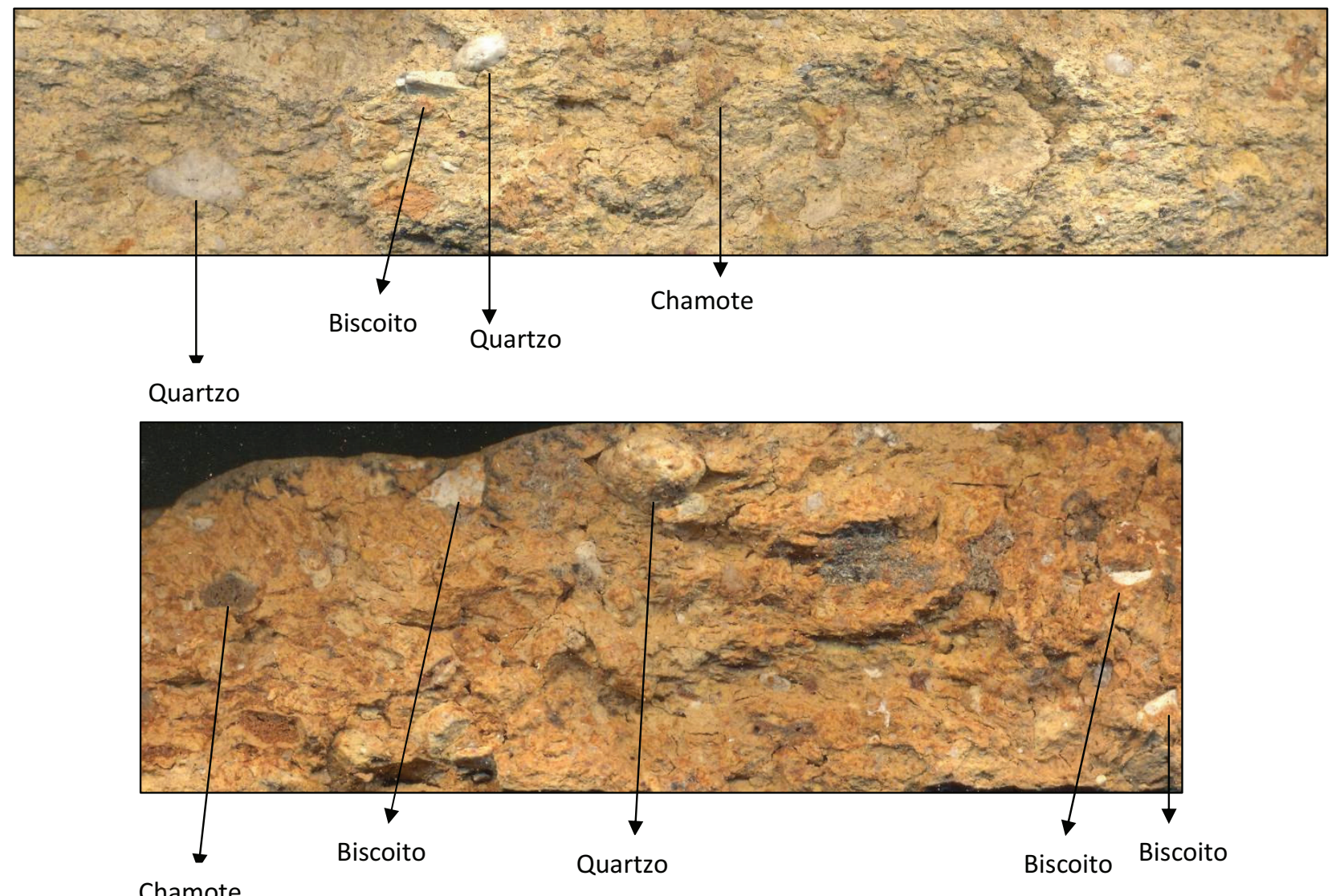


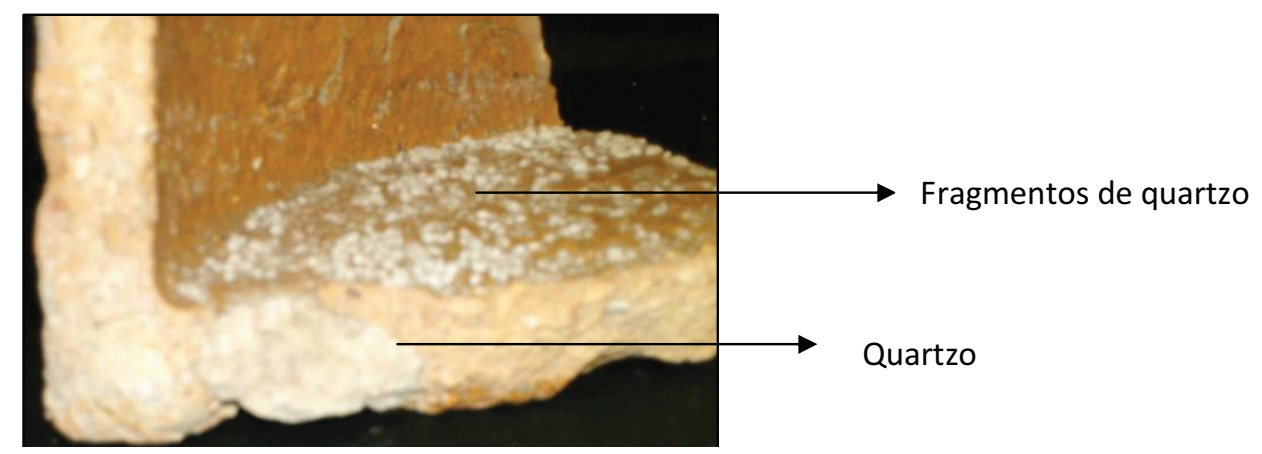

Caixa Refratária com fragmentos de quartzo na parte interna da base e quartzo como anti-plástico
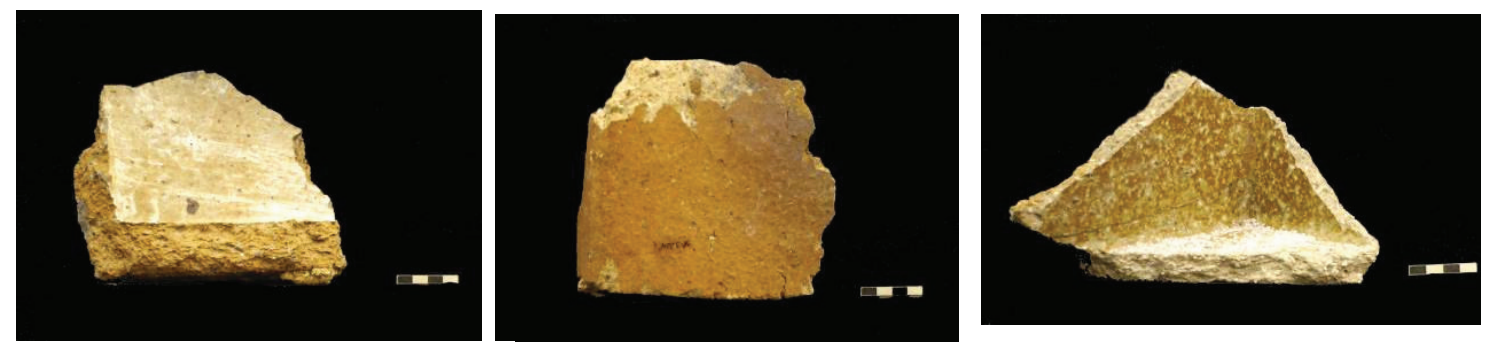

Caixas refratárias quadradas
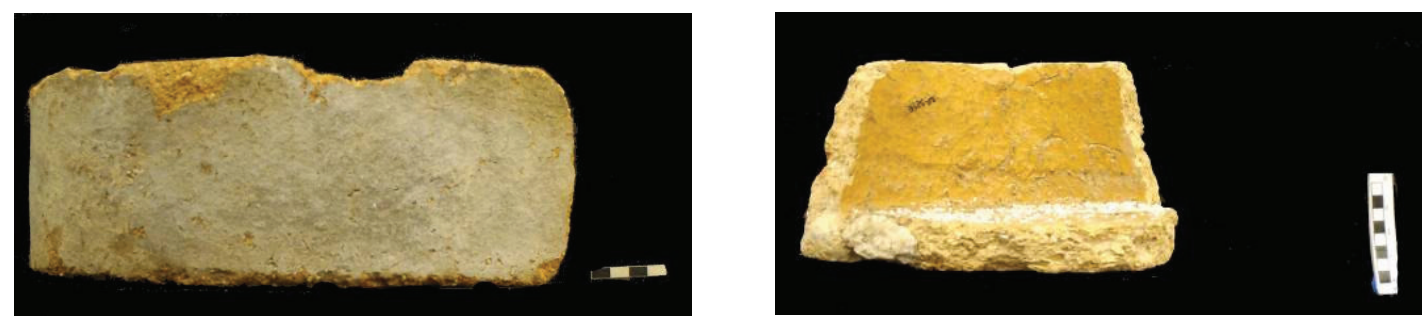

Caixas refratárias elípticas de baixa altura
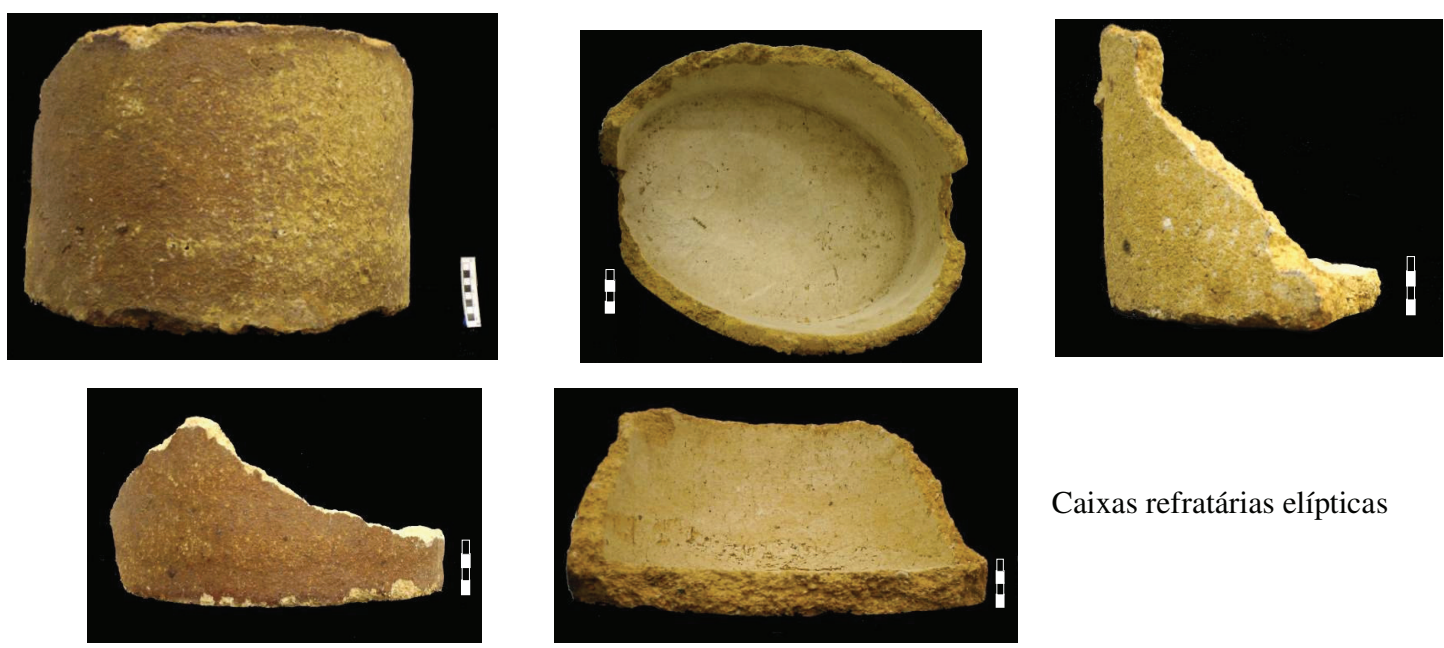

Caixas refratárias elípticas
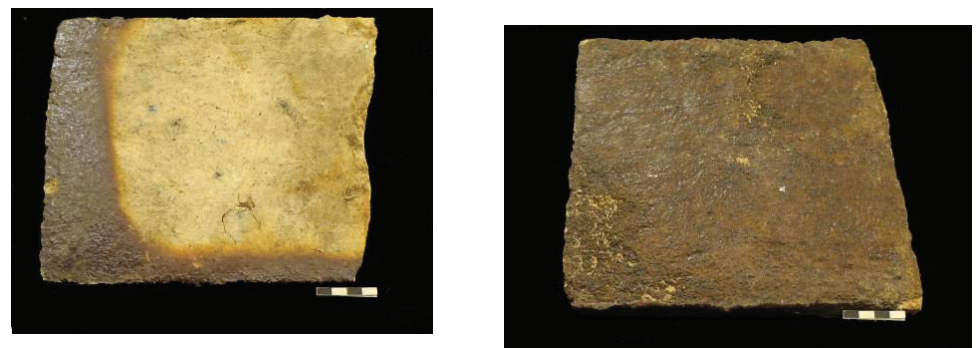

Placas 


\section{G) $\quad \underline{\text { Roletes }}$}

Roletes são utilizados, em geral, para a manufatura de cerâmicas com técnica roletada ou acordelada, na qual são sobrepostos. $\mathrm{O}$ uso de roletes tem ampla difusão no mundo e chega a ser considerado o método clássico de produção cerâmica (MACHADO 2005/2006: 100). O sítio Petybon contém vários destes roletes, feitos da mesma pasta que as caixas refratárias, ou seja, argila refratária com chamote. Assim como elas, caracterizam-se por uma pasta de granulometria grossa com anti-plástico de cacos moídos, tanto de caixas refratárias como de louças vidradas ou no biscoito, associados à anti-plástico mineral, igualmente de grandes proporções.

Notei que existem dois tipos de roletes: um primeiro, de corpo cilíndrico, e um segundo, que possui uma forma cilíndrica, mas que foi achatado (24 peças). Associando dados etnográficos com a presença de roletes ainda fixados às bases e bordas de 4 das caixas refratárias do sítio Petybon, percebi que o segundo tipo de rolete servia para vedar o vão que ficava entre as caixas quando eram empilhadas dentro do forno para queima das louças e biscoitos. Quanto ao primeiro tipo, igualmente através de dados etnográficos e análise do material arqueológico, pude notar que eram roletes com função de concerto, ou seja, quando um fragmento de caixa quebrava, gerando um "buraco" em sua parede, ao invés de ser automaticamente descartada, ela era restaurada com uma parede de roletes superpostos, prolongando, assim, a vida desse vasilhame.

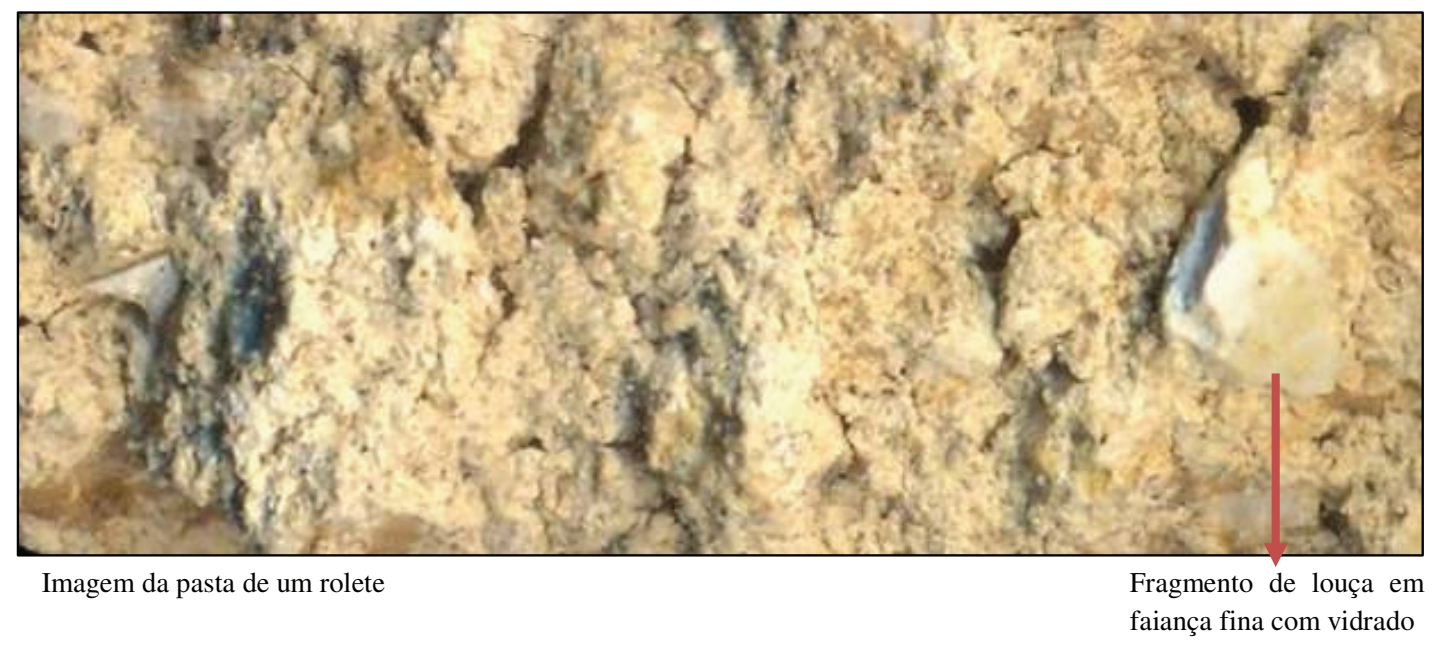



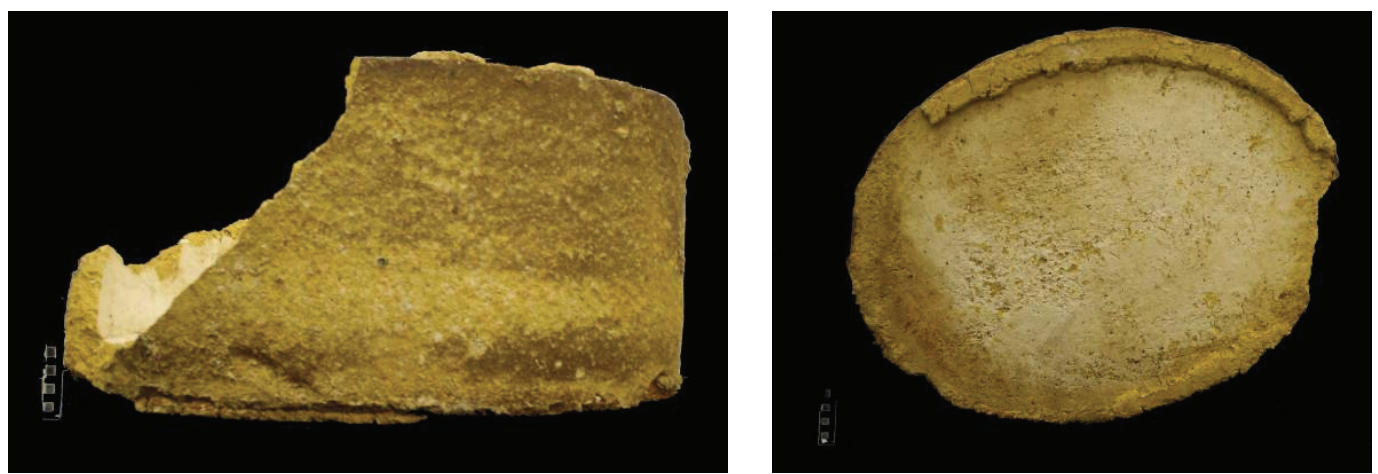

Caixas refratárias com roletes ainda grudados na superfície, tanto na boca quanto na base

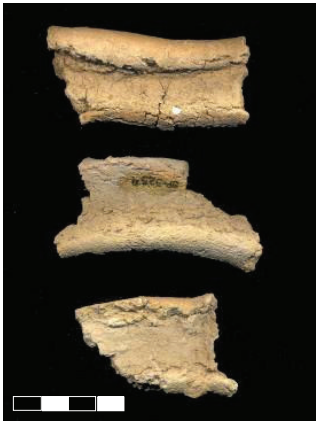

Roletes
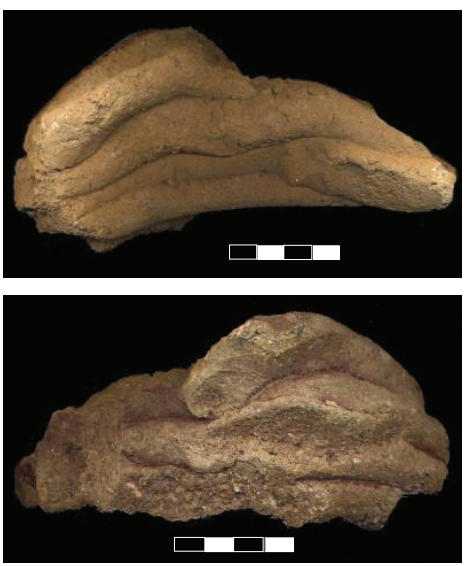

Roletes de concerto do sítio Petvbon

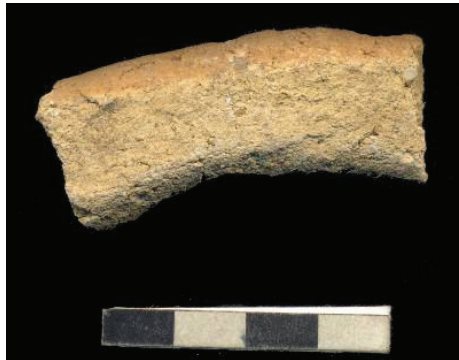

Rolete

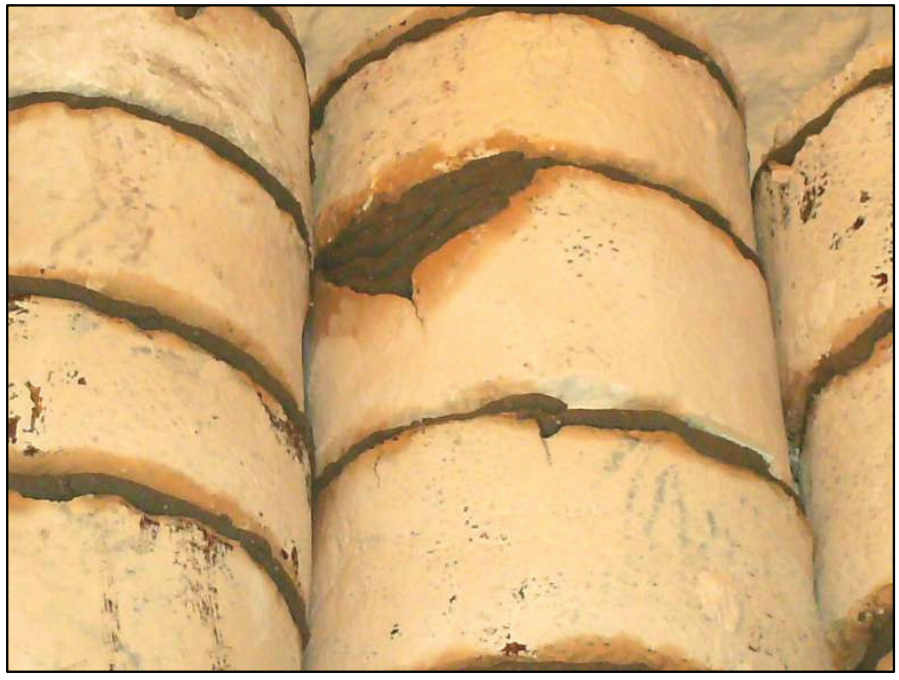

Roletes utilizados para concertar as formas refratárias na Porcelana Monte Sião, atualmente. Percebem-se também os roletes postos entre as formas. A fotografia foi tirada no interior do forno antes da queima. 


\section{H) $\quad$ Moldes de Gesso}

Há registros da utilização de moldes de gesso para a fabricação de cerâmicas por colagem desde o século XV (NORTON 1975: 110). A presença destes vestígios no registro arqueológico infere o uso do processo de colagem no qual a barbotina é vertida para o interior do molde, que absorve a água e contém a pasta que se deposita nas paredes do mesmo, configurando a forma do vasilhame. Para que a louça seja oca, quando se atinge a espessura desejada, o excesso de barbotina é despejado do molde. $\mathrm{O}$ uso dos moldes permite a reprodução de detalhes finos, além de ser estável química e fisicamente, com capacidade de absorção variável, com custos moderados. O processo de colagem com os moldes utiliza-se da pressão hidrostática e da relação da porcentagem de água na pasta líquida (a barbotina).

Os moldes nas indústrias de louça são preparados por uma mistura de gesso e água, cuja relação denomina-se "consistência" e é dada pela expressão $\mathbf{C}=$ massa $\mathbf{H}_{2} \mathbf{O}$ / massa gesso . 100 (AUN 2000). Quanto maior for à consistência, maior será a porosidade e a absorção de água, e menor a resistência mecânica da peça de gesso. É provável que os moldes encontrados no sítio Petybon sejam resultados de descartes dos mesmos, porque depois de um período de uso e reuso, podem perder alguns detalhes da forma desejada devido aos desgastes ocorridos durante o processo (AUN 2000: 178).

A parte em negativo dos moldes é sempre maior do que a peça produzida, pois quanto mais o molde absorve umidade, maior retração ocorre na peça, até que ela descole das paredes do molde e seja retirada do mesmo. Além disso, os negativos nos moldes de prato e nas bases nos moldes de malgas são mais curvos do que o vasilhame que deles resulta, pois há perda de umidade durante a queima, causando uma retração que faz com que essa curvatura das bases se torne planas. Se o molde já for plano, esse movimento durante a queima pode causar rachaduras.

No sítio Petybon, foram encontrados 411 moldes de gesso, sendo que 40 foram analisados com maior afinco para a amostra tendo em vista a parte que compõem (se tampa, se corpo), as dimensões, a louça que será produzida a partir dele e a cor. Assim, dos 40 moldes de gesso, 30 são de cor brancos e 10 rosados. Devido ao grau de degradação do gesso, posso afirmar com certeza que 7 moldes são para malga, 3 para xícaras, 1 para caneca, 6 para prato ou pires e 1 para alça. 


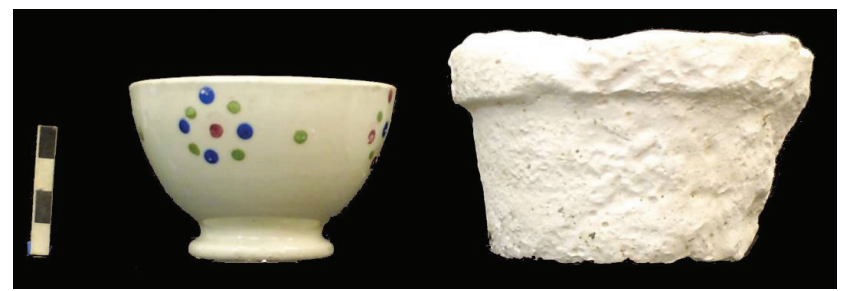

Moldes para malgas com a peça correspondente

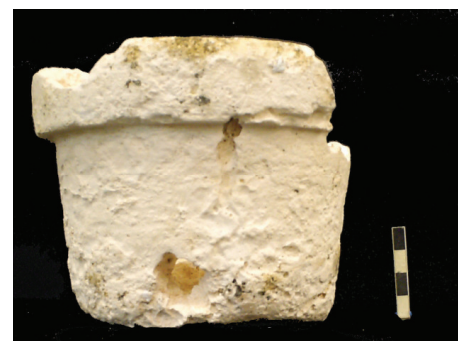

Molde para caneca

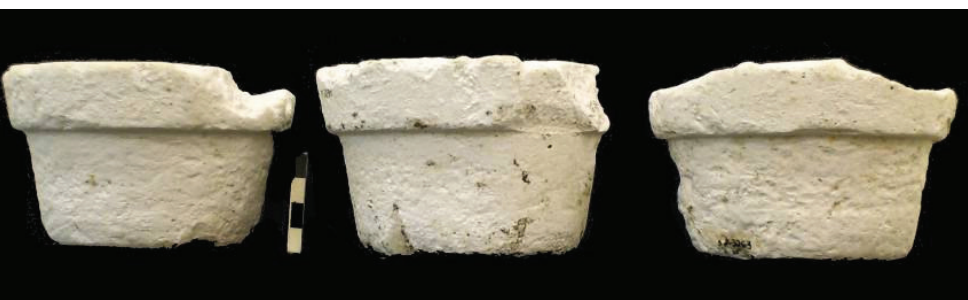

Moldes para malgas

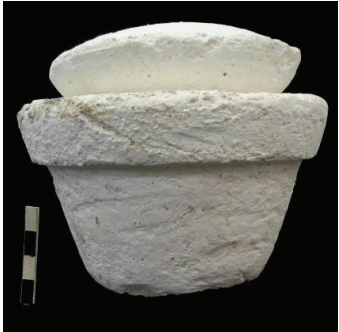

Molde para malga com tampa
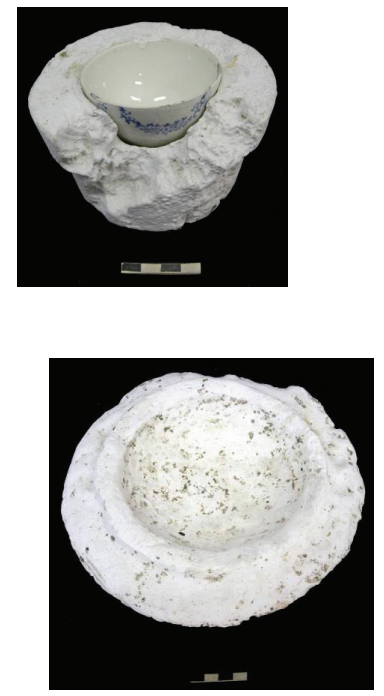

Molde para pires

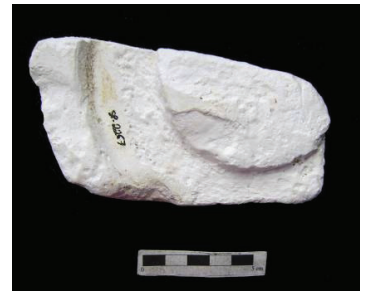

Molde para prato

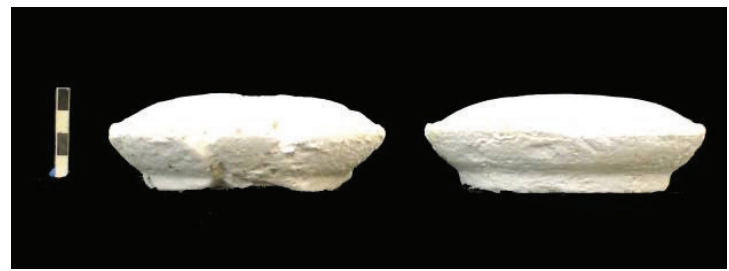

Tampas para moldes 


\title{
CAPÍTULO 3
}

\section{PRODUÇÃO: PARTICULARIDADES E ESPECIFICIDADES NA ESFERA PRODUTIVA}

\author{
SUB-CAPÍTULO 3.1
}

\section{PROCESSO PRODUTIVO NA FÁBRICA DE LOUÇAS SANTA CATHARINA / IRFM - SÃO PAULO: TECNOLOGIAS NACIONAIS E ESTRANGEIRAS PARTICULARIZANDO A LOUÇA EM FAIANÇA FINA NACIONAL}

Pretendo discorrer aqui sobre o processo produtivo das louças em faiança fina na Fábrica de Louças Santa Catharina, cujas etapas foram reconstituídas a partir dos vestígios arqueológicos encontrados no sítio Petybon, vestígios estes que indicam a sequiência operatória que caracteriza e particulariza esta faiança fina nacional. A cadeia operatória levados à cabo durante a produção, resultam em uma "estética" final do objeto, que o originaliza e que colabora com sua identificação e reconhecimento, por vezes difícil, nos sítios arqueológicos históricos no Brasil. Se as louças brasileiras parecem semelhantes às estrangeiras, pretendo, justamente, buscar a diferença nestas semelhanças (SAHLINS 2003: 187). Para isto, será necessário, também, dissertar sobre a conjuntura de instalação da Fábrica nos anos 1910 e sua composição do corpo de trabalhadores e diretores, que resultou na somatória de conhecimentos diversos. Separei, portanto, este capítulo em três partes que correspondem ao que Gallay (2002: 61) chamou elementos intrínsecos e extrínsecos dos artefatos arqueológicos, isto é, as propriedades tecno-morfológicas ligadas à cadeia operatória e os atributos ligados ao contexto no qual esta cadeia está inserida, por quem é "feita" e com quem dialoga.

Para isto, encaro a fabricação de louças como uma produção, uma poética (DE CERTEAU 2007: 39), durante a qual são produzidos significados que, por sua vez, produzem louças. A produção não seria apenas um "processo natural-pragmático de satisfação de necessidades" (SAHLINS 2003: 166); pois durante ela, "os homens produzem objetos para sujeitos sociais específicos, no processo de reprodução de sujeitos por objetos sociais" (SAHLINS 2003: 168). Produzir, portanto, é mais do que uma prática lógica de eficiência material, é uma "intenção cultural” (SAHLINS 2003: 169). E é como intenção cultural, e, 
portanto, enquanto sistema simbólico, que encaro o sistema de produção capitalista no qual está inserida a cadeia operatória das louças em faianças finas estudadas aqui.

A adoção de uma modalidade capitalista de produção, de cunho taylorista, pressupõe que esta modalidade, como tantas outras, gera-se no fulcro do universo cultural dentro da relação retroalimentada entre os meios materiais da organização cultural e a organização dos meios materiais (SAHLINS 2003: 206). Já que as forças materiais do capitalismo se instauram sob a égide da cultura, a produção das louças em faiança fina não é marcada por uma suposta intangibilidade capitalista, mas faz parte de um todo cultural (que não é necessariamente um todo homogêneo). Estas características fazem com que a cadeia operatória seja singular, durante a qual os gestos efetuados em sua seqüência geram atributos que são somados à peça $\mathrm{e}$ que, apesar de estarem além de seu apelo visual, caracterizam, intrinsecamente, estas louças nacionais, refletindo os sistemas simbólicos na qual foram produzidas.

Não existe produção sem um instrumento de produção, mesmo que este instrumento seja a própria mão, chamou atenção Marx em Para a Crítica da Economia Política do Capital (1996: 27). Se este instrumento é o próprio corpo ou uma extensão deste corpo, ele, então, está culturalmente configurado através dos gestos que compõe a produção de um objeto, caracterizando culturalmente o mesmo. Por isso os atributos que analisei nas louças do sítio Petybon têm sempre uma razão de ser, que não inexoralvemente determinista-funcional. Mesmo em condições materiais bastante semelhantes, ordens e finalidades culturais podem ser muito diferentes, sem falar nas opções de estratégias de produção que podem ser concebidas a partir da diversidade de técnicas existentes, negando ou seguindo o exemplo de sociedades vizinhas (SAHLINS 2003: 168). Estas técnicas e tecnologias, enquanto escolhas culturais, resultaram de "uma complexa teia de associações entre o mundo material, o social e o universo simbólico dos diferentes grupos humanos" (SILVA 2002: 126). Assim é o estudo dos sistemas tecnológicos, como o que pretendo apresentar aqui, da cadeia operatória da Fábrica de Louças Santa Catharina, entendido como meio de expressão cultural. Uma vez que uma fábrica de louças inglesa e uma fábrica de louças brasileira não são iguais, em seus mais variados aspectos, os produtos resultantes destes dois universos de produção são diferentes. Para Lemonnier (1993: 14), o que diferencia processos de produção são os modos como as pessoas concebem os objetos, assim como identificam vários elementos a serem feitos e montados, bem como a própria seqüência de montagem.

Por fim, é preciso lembrar que o ato de produção é também um ato de consumo em todos os seus momentos (MARX 1996: 31) - assim como é verdadeiro seu inverso (DE CERTEAU 
2007). A produção só tem sentido no consumo, esfera a qual ainda voltarei. Design, manufatura, distribuição e uso são todas atividades que envolvem traços culturais e organizações sociais (KINGERY 1993: 227), permeadas por escolhas e sistemas tecnológicos (LEMONNIER 1993: 2).

No que concerne à historiografia e bibliografia sobre arqueologia em fábricas de louças, os exemplos são poucos. Geralmente, há mais exemplos, em Arqueologia Histórica, de pesquisas em unidades domésticas ou em universos onde a louça é "consumo", do que em unidades produtivas. Isto porque, claro, uma única unidade produtiva abastece milhares de unidades domésticas, caso contrário haveria um desequilíbrio na balança da demanda. No entanto, é característico dos sistemas capitalistas produzirem mais do que consomem, numa reprodução ampliada que mantém viva a dinâmica do capital (GRUPPI 1980: 23), traço deste modo de produção que pode lançar luz sobre de onde vieram tantas louças que viraram aterro compondo um sítio arqueológico.

No entanto, a Arqueologia Histórica ligada ao estudo de fábricas vem sofrendo acréscimos com os últimos anos. Adoto a abordagens, neste campo, provenientes dos trabalhos de Paul Schakel com o complexo fabril do século XIX, a Harpers Ferry, e suas percepções críticas em relação aos temas da disciplinarização e da modernidade (1993; 1996). Baseandome em Schakel, afirmo que o incremento na capacidade de produção com a criação da Fábrica Santa Catharina em São Paulo é resultado tanto de um crescimento na capacidade de produzir estes itens pelos oleiros e proprietários, como indica uma mudança no universo do comportamento de consumo (LUCAS \& SCHAKEL 1994: 29). Com esta nova maneira de produzir, surgem novas estratégias de produção, compostas por uma organização, comercialização e opções tecnológicas que os produtores selecionam e que integram o andamento desta produção (GIBB, BERNSTEIN, CASSEDY 1990: 18), estratégias com as quais, como se verá adiante, os trabalhadores dialogam com suas diversas táticas (DE CERTEAU 2007).

Vale ressaltar, ainda, os poucos estudos arqueológicos em fábricas de louça branca, mas cujas reflexões e achados puderam dar alguns nortes em relação às possibilidades interpretativas do sítio Petybon. O que os arqueólogos que estudam fábricas de louça pensaram sobre elas? Nos anos 1920, Aubrey Toppin (1922) levou a cabo escavações na Bow China Factory, em Essex, Inglaterra, com o intuito de encontrar a exata localização da Fábrica (que se deu, primeiramente, segundo relatos da descoberta de fragmentos ainda no século XIX) e diagnosticar as decorações produzidas. Toppin encontrou uma enorme quantidade de biscoitos, 
que caracterizaram a maior parte da coleção, assim como moldes para produção de peças com decoração em relevo, formas refratárias, kiln furniture, e até mesmo inscrições numéricas (em tinta azul). Entre os anos 1950 e 1970, foi escavada a Longton Hall Manufactory, uma fábrica de porcelanas inglesas do século XVIII, cujas análises giraram em torno da investigação da cadeia produtiva e da análise química dos fragmentos para percepções sobre mudanças de composição durante a existência da Fábrica. Haggarty e McIntyre (1996), no final dos anos 1980, escavaram a Newbegging Pottery, em Musselburgh, Escócia, uma fábrica do século XIX, que encerrou suas atividades nos anos 1920; os arqueólogos procuraram estudar a relação entre os padrões decorativos e os diferentes proprietários da fábrica, além de descrever os artefatos encontrados, tais quais os biscoitos, muitos deles decorados, biscuit e o kiln furniture, além de apresentarem os resquícios de construções e embasamentos dos antigos fornos. Barker e Horton (1999) escavaram, no começo dos anos 1990, a Coalport Chinaworks Factory, na Inglaterra, e os estudos focaram nas análises geoquímicas e reflexões sobre as mudanças em tecnologias e pastas na produção, mas também mostrar formas, decorações e o mobiliário do forno, tão difícil de ser compreendido, como separadores, formas, etc.

No final dos anos 1990, Barker e Cole (1998) publicam os resultados de escavações arqueológicas em Digging For Early Porcelain, cujo objetivo foi trabalhar em seis fábricas de porcelana (William Littler Pottery em Longton Hall, William Littler Pottery em West Pans, The Limehouse Factory, uma produção em Newcastle-under-Lyme, Worcester Factory e a China Factory em Shaw's Brow, Liverpool), com produções iniciadas no século XVIII, chamando atenção para as primeiras tentativas de produção desta louça na Inglaterra, como a produção lidou com diversos problemas (como o controle da queima), a relação entre diferentes fábricas que compartilharam proprietários e funcionários, e como elas investiram em inovação e no desenvolvimento de novas tecnologias. Já no século XXI, a Brownlow Hill Factory, em Liverpool, que iniciou sua produção no século XVIII, foi escavada com intuito não apenas de possibilitar a identificação de artefatos arqueológicos caracterizados, em geral, nos sítios de unidades domésticas como "sem proveniência", como também analisar as condições da produção reconstruindo a atmosfera dos fornos, calculando gastos e produções anuais, acessando as mudanças tecnológicas e as confrontando com informações históricas sobre as manufaturas de porcelanas, indicando mudanças, no tempo, na composição das pastas e vidrados, avaliando as possíveis fontes de matéria-prima e as possibilidades de relações e trocas de conhecimento tecnológico entre produtores contemporâneos (OWEN \& HILLS 2003). 
Na América Latina, conta-se com a magnífica referência das pesquisas de Monika Therrien (MEJÌA \& THERRIEN, 2001/2002; THERRIEN, JAMARILLO PACHECO \& SALAMANCA 2003; THERRIEN 2002; THERRIEN 2004; THERRIEN 2007) sobre a Fábrica de Loza Bogotana, na Colômbia, nas quais a autora procurou tecer reflexões em torno da produção, circulação e consumo da louça industrial nacional, enquanto cerâmica de fabricação local pouco abordada pela literatura, imergindo a Fábrica em um contexto histórico de projetos de modernização para a Bogotá do século XIX, cujos intuitos giravam em torno de promover mudanças na ordem socioeconômica e alterar tradições vistas como arraigadas ao antigo regime colonial. Therrien propõe, ainda, uma arqueografia da louça nacional, para diferenciá-las de suas comparsas estrangeiras. As abordagens e os estudos da arqueóloga marcaram de forma definitiva a pesquisa e as reflexões em torno da Fábrica Santa Catharina e das louças nacionais em faiança fina.

No Brasil, apenas uma pesquisadora enveredou pelo difícil caminho da arqueologia das fábricas de louça branca nacional, desenvolvendo igualmente uma pesquisa de mestrado na UFPR. As pesquisas de Martha Morales (2008a; 200b), através de uma abordagem que versa sobre a Arqueologia e a História, tratam da primeira fábrica de faianças finas do país, a Fábrica de Louças Colombo, no Paraná, a partir da qual tece reflexões sobre as louças produzidas e as diferentes etapas da Fábrica, pautando-se nas mudanças não apenas de proprietários como da composição do corpo de trabalhadores, tendo como pano de fundo questões relacionadas às teorias de formação de identidades culturais.

A seguir, constam os sub-capítulos cujas temáticas versa sobre o universo da produção. São reflexões a respeito da cadeia operatória e dos agentes envolvidos, de temáticas pontuais como visões em torno dos defeitos e sua relação com as possibilidades de consumo e a presença de marcas digitais e artefatos com inscrições em uma fábrica de louça, permitindo um diálogo com o cotidiano e a presença dos trabalhadores no opressor sistema fabril. 


\subsection{1 - A cadeia operatória de produção das louças do sítio arqueológico Petybon}

... Eis o rumor dos quebradores, dos moinhos, que pulverisam o branco calcareo, dezenas de cylindros preparam o caolim, numerosos e enormes agitadores preparam a primeira massa que, atravez de outras machinas torna-se subtil, extendese, adquire elasticidade e resistência para em seguida ser adaptada á modellagem. Para esta operação servem centenas de turbinas horizontaes, sobre as quaes a massa guiada pela mão experta do operário, toma a fórma definitiva que se lhe quer dar $e$ transforma-se em prato, tigella, etc... (PICCAROLO \& LINOCCHI 1918: 148-149)

Quando Mauss investigou "as maneiras pelas quais os homens, de sociedade a sociedade, de uma forma tradicional, sabem servir-se de seu corpo" (MAUSS 1974: 401), mostrou que nossos gestos são culturais e históricos, caracterizando identidades e diferenciando culturas enquanto idiossincrasias sociais (MAUSS 1974: 404). Estes gestos e ações, culturalmente caracterizados, compõem um conjunto de técnicas que seguem, por vezes, lógicas nãotecnológicas (VAN DER LEEUW 1993: 17), às quais Leroi-Gourhan chamou "cadeia operatória" ou chaîne opératoire, isto é, quando técnicas escolhidas são aplicadas à matériasprimas em sequiências e combinações lógicas de gestos (VIANA 2003: 187; DAVID \& KRAMER 2001: 140), que transformam esses materiais brutos em produtos manufaturados (VAN DER LEEUW 1993: 240). Os gestos, as atitudes e as maneiras de se comportar no domínio do banal e do cotidiano "constituem os elementos de ligação ao grupo social de origem, dos quais o indivíduo nunca se consegue libertar por completo mesmo quando transplantado para uma outra classe ou etnia" (LEROI-GOURHAN 1983: 27). Veremos que a cadeia operatória que caracteriza as louças do sítio Petybon são uma somatória de conhecimentos de inúmeros indivíduos, por vezes, de origens diferentes, que compuseram um todo coerente que particulariza essa louça brasileira.

Esta longa gestualização do corpo através de um aparato tecnológico, a fim de produzir um artefato, caracteriza este artefato em sua performance final, mas não só. O uso específico para o qual um vasilhame é destinado implica em escolhas tecnológicas que resultam numa determinada forma, que corresponde às necessidades de sua performance (SILVA 2000: 183) por exemplo, a opção por não deixar o biscoito aparente na base dos recipientes e as tentativas de burlar o gretamento. Pressuponho aqui, que toda a cadeia de produção particulariza o objeto, isto é, o "fazer" no qual se somam sistemas simbólicos arraigados aos gestos que fabricam este mesmo artefato, caracterizando-o. Este "fazer" configura o equilíbrio dinâmico entre o oleiro e seu material (VAN DER LEEUW 1993: 243). Assim, etapas da produção, que não 
necessariamente terão impacto visual no produto final, são importantes para caracterizarem um artefato produzido por um determinado universo cultural. Estas etapas que não "aparecem" no produto final, apesar de relacionados aos processos envolvidos em sua produção, têm a ver, às vezes, com o fato de que "em cada seqüência, os gestos associados a ela deixam marcas impressas, no entanto, geralmente, os gestos associados à seqüência seguinte normalmente apagam as marcas deixadas pelos gestos anteriores" (VIANA 2003: 187) - é o caso dos acabamentos de superfície e sua relação com as impressões digitais, assim como a relação entre as marcas deixadas pelo uso de ferramentas cortantes no acabamento e o uso de esponjas ou, ainda, a relação destas marcas com a esmaltação que as preenche e "camufla", como será visto neste trabalho.

É assim que vejo essa louça brasileira: apesar de características visíveis que a diferenciam das demais louças estrangeiras e que resguardam sua originalidade, existem etapas do processo de produção não-visíveis e que constituem sua sequiência operatória. "As especificidades estão ao longo de toda a cadeia e há maneiras diferentes de realizar todas as etapas, por mais que elas tenham o mesmo fim" (BUENO 2005: 34); estas maneiras diferentes envolvem escolhas tecnológicas articuladas dentro de um universo de possibilidades culturalmente constituído. Por isso, a tecnologia da produção da cerâmica branca deve ser entendida como "um sistema de representação social no qual estão inseridos, além de artefatos, conhecimentos/habilidades específicas, relações sociais de trabalho, redes de ensino aprendizagem e, enfim, uma visão de mundo específica" (BUENO 2005: 25). Mesmo num ambiente de manufatura fabril e produção em série, a técnica é encarada como um fenômeno social, muito mais cultural que adaptativo (VAN DER LEEUW 1993: 239).

$\mathrm{Na}$ cadeia operatória da louça em faiança fina nacional atributos são incorporados no decurso da produção, processo que envolve uma série de decisões técnicas que estão imersas e condicionadas por relações sociais e práticas culturais (DAVID \& KRAMER 2001: 140). Todos estes atributos que caracterizam essa cerâmica são resultantes de escolhas tecnológicas possíveis, disponibilizadas pelo ambiente, pela própria tradição cultural ou contatos externos (LEMONNIER 1993: 6). Defendendo a originalidade desta louça brasileira e os traços que a diferenciam das louças inglesas, por exemplo, não penso que suas tecnologias de produção surgiram a partir do nada. O empréstimo de técnicas locais ou estrangeiras, de oleiros brasileiros, italianos ou ingleses, e a decisão por adotar procedimentos tecnológicos existentes em outras cadeias de produção é, em si, uma inovação, porque prevê que a técnica emprestada ache seu lugar na nova cadeia, fazendo com que um novo traço tecnológico tenha que se 
encaixar fisicamente em práticas já existentes (LEMONNIER 1993: 13). Este novo gesto, artefato ou sequência operatória deve ser entendido como "a potencial means of actions on the material world" (LEMONNIER 1993: 14).

A produção de louças em faiança fina no Brasil, enquanto fato inédito poderia ser encarada como uma invenção técnica em relação às cadeia operatórias das louças de barro já produzidas aqui - implicando numa quebra de rotina. Contudo, e que uma invenção é sempre baseada numa reorganização de elementos já presentes na cultura material local, emprestar é adaptar algo a um corpo pré-existente (LEMONNIER 1993: 21). Fica difícil, e talvez seja desnecessário, ou mesmo impossível, saber o que é nacional e o que é estrangeiro na cadeia de produção dessa louça nacional. Estudar a produção desta louça, suas escolhas tecnológicas e suas características, visíveis ou não no produto final, é fazer uma crítica às abordagens que buscam o "nacional por subtração" (SCHWARZ 2005), ou seja, a busca que caracterizou épocas como o modernismo, por exemplo, na qual acreditava-se ser possível "limpar" a cultura de elementos considerados forâneos para chegar a seu corpo "original" - elucidante do caso, são os roletes em argila refratária. Empréstimos sempre existem, uma vez que as culturas não são isoladas no mundo, mas isso não implica em meras "cópias aculturadas". Assumo que estudar o sistema tecnológico da produção de louças em faiança fina em uma fábrica brasileira, permite diferenciá-las das estrangeiras, porque imerso em culturas diferenciadas, permitindo compreender sua cadeia operatória e as dimensões sociais e simbólicas que configuram esse sistema tecnológico como meio de expressão cultural (SILVA 2002: 132). Daí mais um argumento que corrobora a impossibilidade da louça brasileira ser uma "cópia" ou uma "cópia mal feita" (SCHWARZ 2005).

Ao longo da apresentação da cadeia operatória das louças, pensada a partir dos vestígios do sítio arqueológico Petybon, perceber-se-á a produção de algumas "respostas" tecnológicas a problemas da produção, ao que Akrich e Latour chamaram translation. Essas "respostas" relacionam-se a lógicas não-tecnológicas que perpassam as escolhas tecnológicas das cadeias operatórias, bastante plurais e complexas (LEMONNIER 1993: 17). Fatores econômicos, étnicos e políticos têm peso importante na adoção ou rejeição de um traço tecnológico, e as respostas aos problemas surgidos durante a produção dialogam diretamente com eles (LEMONNIER 1993: 18). Na cadeia do sítio Petybon, o taylorismo, como característico de uma produção capitalista standard, com uma lógica específica de tempo e produção, além de uma relação particular com os trabalhadores, tem bastante a ver com a configuração da sequência operatória levada a cabo para a produção das louças brancas. Muitos dos elementos 
introduzidos na cadeia por ideologias cientificistas do trabalho, por vezes, são invisíveis no vasilhame final, mas têm um papel decisivo no status do oleiro, do consumidor e do produto em si.

A cadeia operatória das louças em faiança fina da Fábrica Santa Catharina, como qualquer outra cadeia, relaciona-se às conjunturas sociais, políticas e econômicas na qual está inserida e a partir da qual foi pensada, sendo possível, a partir de sua investigação, identificar e compreender as dimensões políticas da organização da produção e das relações sociais no interior da Fábrica (RIBEIRO 2006). A cadeia e os operários que dela participaram são perpassados por métodos de racionalização e cientificidade do trabalho, como o taylorismo. Diferentemente de cadeias operatórias onde o oleiro ou oleira retém o conhecimento de todo o processo e/ou onde produz a cerâmica que consome, no taylorismo, a ideologia capitalista de consumo e produção caracteriza um universo onde o trabalhador não mais domina todo o processo de produção, mas apenas alguns gestos dentro da cadeia, fabricando um artefato para um mercado consumidor que não é estritamente ele próprio - que pode mesmo nunca consumir um objeto que produziu. Ao que, Marx chamou alienação do trabalhador.

Além disso, o sistema taylorista na Fábrica configurou uma produção que conjugou mãode-obra intensiva com artefatos mecânicos simples. Esta cadeia de produção de louças visava, portanto, obter a maior quantidade possível através de uma rigorosa coordenação dos operários em termos de tempo e sincronização das tarefas (RIBEIRO 2006). Conseguinte, essa organização científica do trabalho objetivava facilitar a utilização de uma mão-de-obra sem experiência de trabalho industrial, garantindo uma elevada produtividade, exatamente como parece ter sido o caso da Santa Catharina, onde a maior parte dos operários deveria ter pouca experiência com um universo fabril, assim como com a produção de louça branca, destarte a experiência de alguns com produção de cerâmica vermelha.

Na cadeia operatória de tipo taylorista, a divisão operativa do trabalho faz com que cada operário execute, idealmente, apenas uma única tarefa, "se possível abreviada a um gesto simples" (RIBEIRO 2006), uma cadeia operatória que sujeita os operários a ritmos de trabalho muito intensos, marcados por gestos simples repetidos quase até a exaustão (RIBEIRO 2006: 10) - ao que Leroi-Gourhan (1983: 52) chamou "taylorização dos gestos" e Michel Foucault (2007: 107) de "enquadramento dos gestos". Além disso, esta cadeia, de cunho fabril, faz com que várias "mãos" produzam um mesmo artefato, ou seja, gestos individuais de diferentes indivíduos compõem a seqüência operatória de uma mesma xícara. Desse modo, cada corpo faz um gesto segundo sua própria historia de vida e visão de mundo, compartilhados ou não em um 
universo cultural, que "marca" a louça de diferentes maneiras. No entanto, para a conformação de uma cadeia em níveis industriais, como a seqüência operatória no taylorismo, é necessário que, não obstante os micro-estilos de exteriorizar um gesto, busque-se características comuns e minimamente semelhantes dos passos que compõem essa cadeia, para que consiga-se traçar um todo coerente de produção, onde a particularidade de cada gesto é ilimitada dentro dos limites de uma visão de mundo, cultura ou comportamento, que é a cadeia operatória - ou seja, apresentando os passos de um todo coordenado (VAN DER LEEUW 1993: 258). A padronização dos gestos implicados no processo de produção da louça em faiança fina na Fábrica de Louças Santa Catharina, gerou uma padronização na forma final dos artefatos (BUENO 2005-2006: 42), caracterizando uma produção industrial em larga escala.

É a partir destas reflexões que a "formação das cadeias operatórias levanta, nas suas diferentes etapas, o problema das relações entre o indivíduo e a sociedade" (LEROIGOURHAN 1983: 25); o diálogo entre os gestos individuais dos trabalhadores oleiros e um background coletivo conformando a cadeia operatória taylorista. Uma dialética entre as diferentes "cabeças" que pensam e materializam a cadeia, os proprietários e os operários.

Ressalva seja feita ao fato de que apesar da existência de fontes escritas e etnográficas que auxiliem na descrição da cadeia operatória da produção de louças em faiança fina, tentarei reconstituir a cadeia baseando-me mais nos vestígios materiais encontrados no sítio Petybon, restringindo-me aos limites interpretativos do registro arqueológico. Por isso, etapas geralmente atestadas nos estudos da cadeia operatória, tanto cerâmica quanto lítica, como as coletas de matéria prima não serão abordadas, pela própria limitação do registro. Além da complexificação do acesso às fontes de matéria-prima num ambiente fabril, por diversas estratégias de aquisição, compra e venda, a existência de meios de transporte e táticas de consumo faz com que estas possam vir até mesmo de fontes trans-oceânicas. É necessário lembrar, também, que enquanto cadeia taylorista, a coleta de matéria-prima pode nem mesmo ter relação com oleiros.

Neste item, enfim, me aterei ao processo que leva à fabricação das formas, apesar de estar atento ao aspecto rizomático das cadeias operatórias (tanto no que concerne a seu caráter de entrelaçamento com outras cadeias, como caracterizando-as segundo a acepção deleuziana de "rizoma temporal"): as cadeias, portanto, se juntam num todo complexo de cadeias operatórias infinitas, imbricamento que tende a uma coerência estrutural (SILVA 2002: 123). Assim, não dissertarei, com maior profundidade, a cerca da cadeia operatória que caracteriza as decorações. Mesmo porque, tentarei ater-me ao que Van der Leeuw (1993: 250) chamou de 
elementos invariáveis da sequência operatória básica da fabricação da louça. Como veremos, a decoração é móvel na cadeia operatória, podendo ser aplicada em diversos pontos da produção (LEMONNIER 1993: 258).

O quadro e o fluxograma que vêm a seguir são: no quadro, procurei organizar as diferentes etapas de produção com base no material arqueológico, pondo a descrição dos vestígios que me levaram a conclusão da existência da etapa produtiva; em vermelho, seguem as partes que são variáveis e que não são imprescindíveis para a formação da sequência operatória básica de construção da peça. O fluxograma mostra, igualmente, a cadeia operatória: em azul e verde estão as etapas da sequência básica de produção, e em vermelho, os elementos variáveis. Os polígonos azuis são compostos pelos dados baseados nos registros arqueológicos e os verdes são baseados em registros escritos e fotográficos que descrevem ou apontam etapas que não podem ser inferidas a partir do sítio arqueológico. 

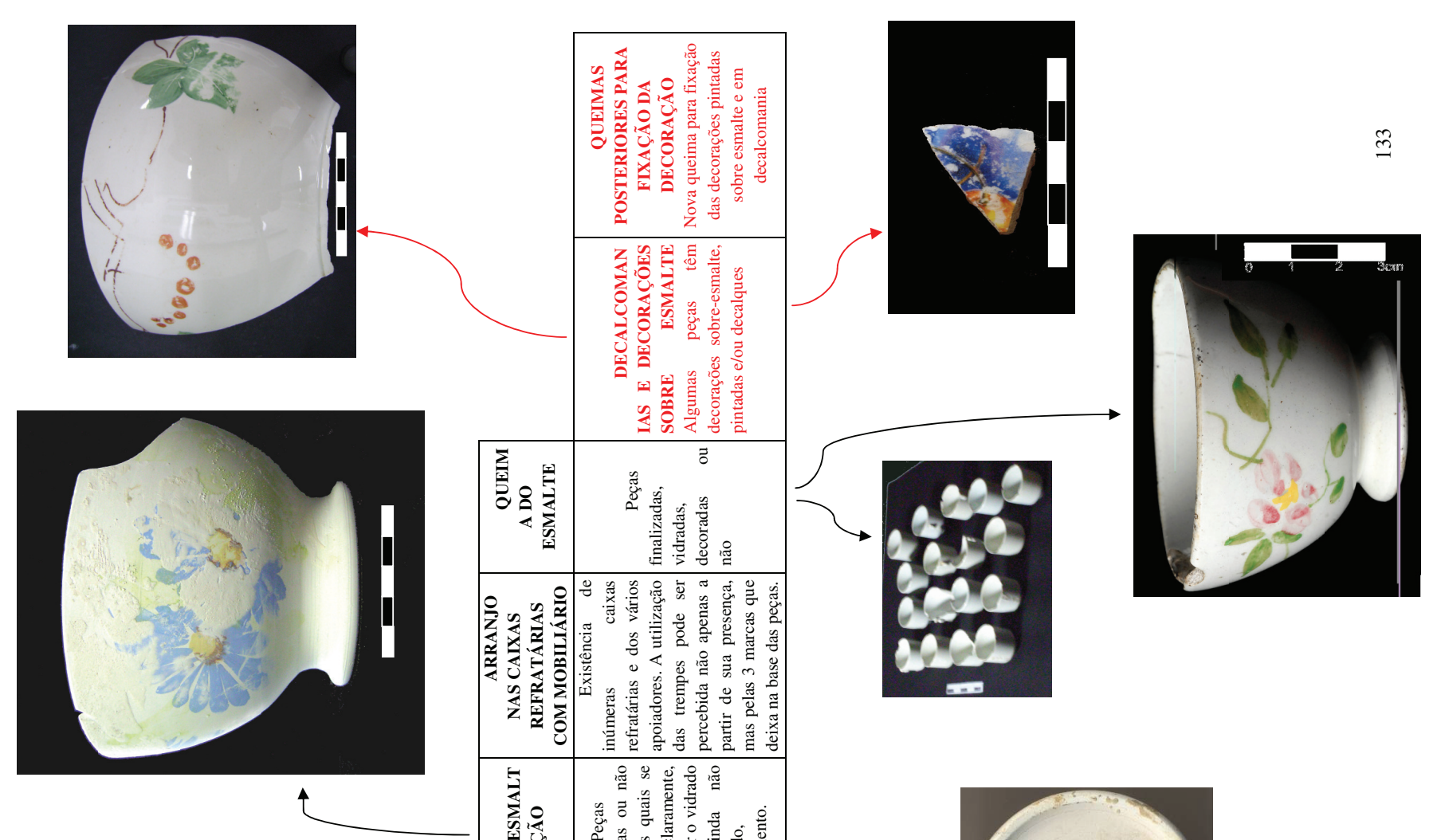

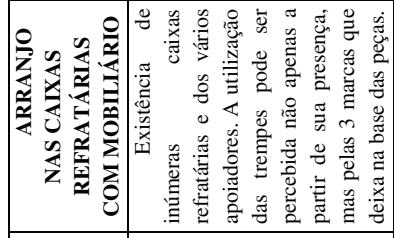
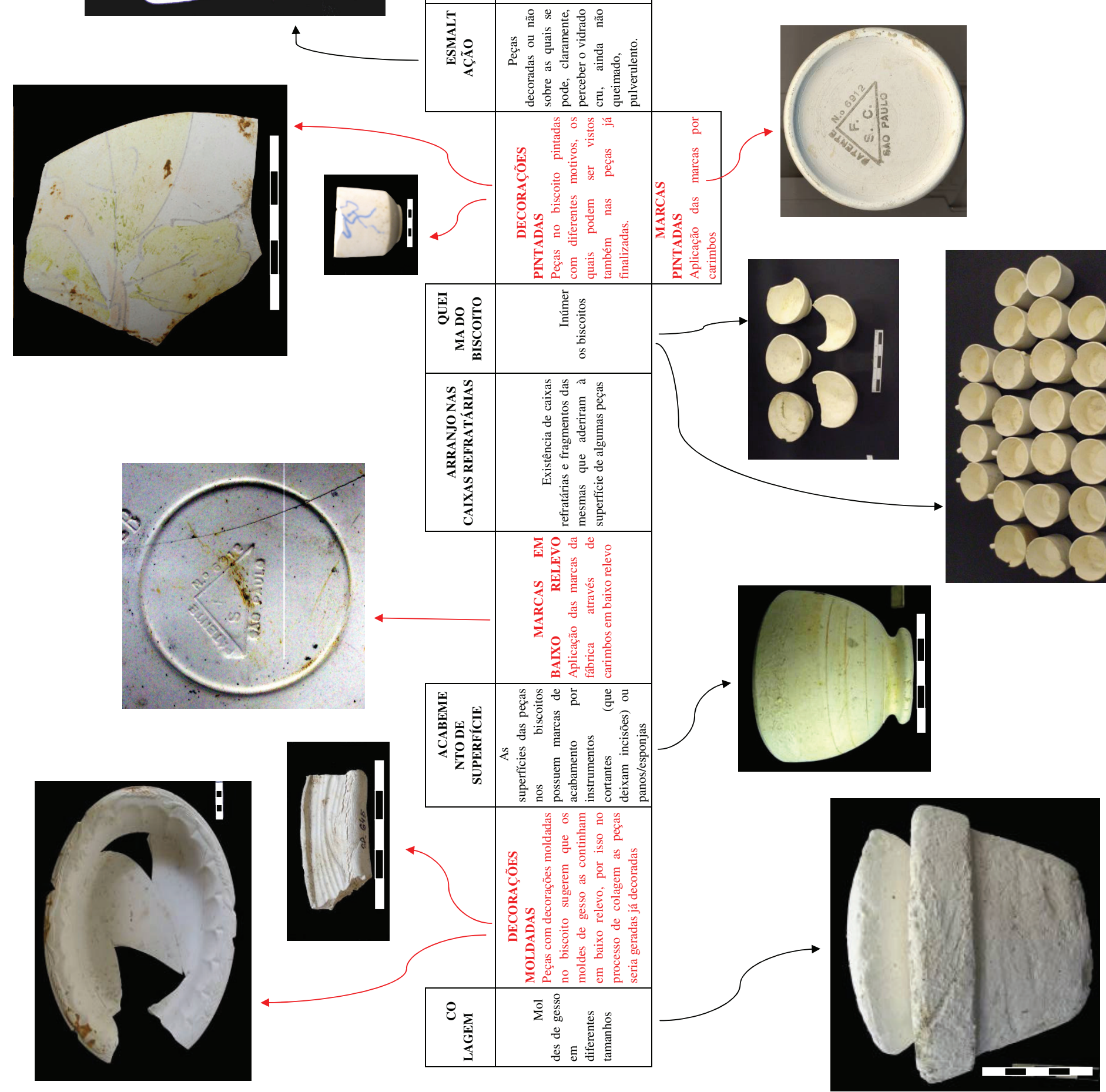

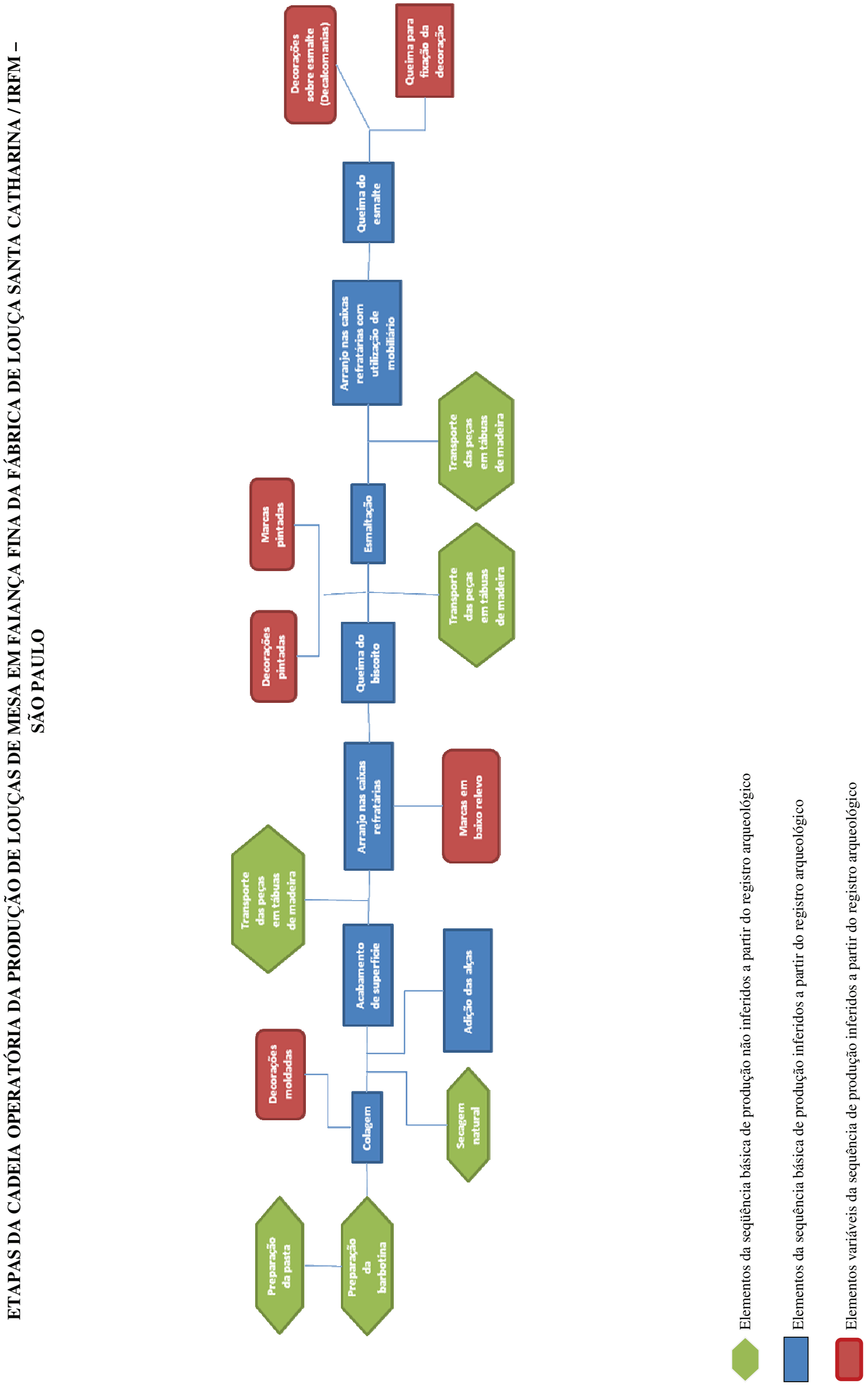
Deste modo, temos o seguinte:

As matérias primas em fábricas de cerâmica como esta são, em geral, compradas de terceiros, a proximidade das fontes em relação à fábrica favorecendo seu barateamento. $\mathrm{Na}$ Fábrica Santa Catharina, a cadeia operatória se inicia no preparo da pasta e não na coleta de matérias-primas, que não está mais sob responsabilidade da produção. Após a aquisição e armazenamento das matérias-primas na Fábrica, as mesmas são postas em quantidade determinada no tamborão (um enorme moedor e triturador giratório em forma de barril). Somam-se a argila, o caulim, o quartzo e o feldspato, a serem moídos e misturados. Este pó é diluído em água formando uma massa aquosa que é dividida em máquinas de prensa para secagem e conformação da pasta em forma de discos, para armazenagem. Para utilização, estes discos são novamente imersos e misturados à água, formando a barbotina. A barbotina é então vertida, através de baldes, ou algum outro recipiente côncavo, nos moldes de gesso, postos enfileirados em bancadas de madeira, um processo de conformação chamado colagem (slip casting). Os moldes contêm as formas das futuras louças em negativo. Neste ponto, também é realizada a decoração dita "superfície modificada" ou moldada, pois são nos moldes, em baixo relevo, que estão as decorações como os trigais. Este tipo de decoração diminui as etapas da cadeia operatória barateando o custo da produção, já que a construção da forma e a decoração constituem uma única etapa.

"No processo de colagem com drenagem, o molde de gesso absorve parte da água da barbotina, formando uma camada de massa rígida, espessa o suficiente para agüentar o próprio peso, e então o excesso de barbotina é despejado. É importante controlar-se a densidade da barbotina, assim como também o tempo de formação da camada, pois ele vai inferir no sistema produtivo e no produto final. Nas indústrias não automatizadas, onde o operário faz a colagem, deve ser conhecido o tempo de formação de camada para calcular o número de moldes de uma bancada. Ao término do enchimento do último molde da bancada, já deve estar em tempo de se virar o primeiro" (AUN 2000: 180). Motta, Tanno e Cabral Júnior (1993: 158) descrevem a colagem como um "processo cerâmico que se baseia na retirada lenta de água de uma suspensão densa (ou barbotina) com a conseqüente formação de uma parede, ou torta no contato com a superfície filtrante, isto é, vertendo-se a barbotina num molde de gesso, o molde absorve a água da barbotina por capilaridade, enquanto as partículas sólidas vão-se acomodando contra a superfície do molde. A peça assim formada apresentará uma configuração externa que reproduz a forma interna do molde".

A porosidade dos moldes de gesso absorve a água da barbotina e a pasta em suspensão se acumula nas paredes do mesmo. Quando a espessura, controlada por um tempo $x$ da 
barbotina nos moldes, alcançou o tamanho desejado, o trabalhador então retira dos moldes o excesso de barbotina, vertendo-o. Por mais algum tempo, a pasta crua, ainda mole, fica no molde para que este absorva ainda mais água, e a forma ganhe uma dureza minimamente manipulável. Com a absorção da água, há uma retração da forma que diminui em tamanho descolando-se das paredes do molde.

Após a retirada das formas do molde, os vasilhames, já em seu formato final, são acumulados em estantes de madeira para secagem natural. Segundo fontes escritas, na Fábrica, a "sala de seccação" tinha um "systema engenhosissimo de aberturas" onde era mantida em “incessante ventilação" (PICCAROLO \& LINOCCHI 1918: 148). A etapa da secagem natural é imprescindível para diminuição da umidade da peça, reduzindo, conseqüentemente, o tempo de duração da queima.

Portanto, diferente da produção em torno, acordelado ou outra técnica, a topologia (topology) (LEMONNIER 1993: 257) do artefato não era comum a todos os oleiros, quando exteriorizam um design que têm em mente, mesmo de maneira inconsciente, como ocorreria com oleiros em outros universos; no presente processo, a forma já é dada pelo molde, ela é quase fixa (para ser standard). Na verdade, a topologia das louças, na Fábrica, está restrita a um número pequeno de trabalhadores oleiros, que materializam uma certa forma segundo a ideologia dos proprietários e gerentes da fábrica, que pensam as formas a serem produzidas, e segundo suas próprias maneiras de materializar esta mesma forma, de acordo com muitos de seus próprios pressupostos e escolhas tecnológicas. Este operário específico, dentre poucos na Fábrica, conhece toda a produção de uma cerâmica em torno, já que são eles quem fazem as chamadas matrizes, isto é, as formas originais, os modelos, a partir das quais serão feitos os moldes de gesso. As matrizes são peças torneadas, compactas, a partir das quais são feitos os moldes de gesso, que são, assim, negativos das formas. Confirma a tese marxista da perda do conhecimento do total do processo produtivo pela maioria dos trabalhadores, assim como a compartimentação deste mesmo saber em uma cadeia de cunho taylorista. Mesmo que aqueles poucos oleiros fabricassem cerâmicas torneadas, elas não são os objetos vendidos para consumo pela Fábrica; desse modo, os mesmos não dominam todo o processo de fabricação da louça por colagem porque participam apenas de uma parte do todo, a fabricação dos modelos torneados (que, são, per se, uma cadeia operatória). Por isso mesmo, o processo onde o oleiro poderá mais se expressar é o da decoração manual.

Após o que, são os vasilhames, já em sua forma final, transportados para a seção de acabamentos, onde "as irregularidades, tanto da superfície quanto da própria forma, podem ser corrigidas" (MACHADO 2005/2006: 104). Antes disso, os recipientes que terão alças vão para 
um setor de adição das alças, anexadas ao corpo do vasilhame também ainda cruas. $\mathrm{O}$ acabamento, nesta etapa, tem por objetivo eliminar as imperfeições da peça: ocasionalmente, algum pedaço de gesso aderiu à superfície, poeira acumulou nas peças ou pedaços de argila. Apenas aqui são utilizados acessórios que não se relacionam necessariamente ao núcleo do processo de manufatura da materialização das formas (VAN DER LEEUW 1993: 261). A utilização de acessórios como os instrumentos e ferramentas usadas nesta etapa da cadeia operatória da produção das louças constitui o que Van der Leeuw chamou executive functions, aspectos da tradição da produção abertas a modificação ou substituição, que, em geral, estão relacionadas a escolhas conscientes.

Enquanto colagem, com a utilização dos moldes de gesso, um dos aspectos da produção que só é possível inferir pela própria existência dos moldes, já que não há marcas necessariamente nas peças, é a existência das "costuras", isto é, rebarbas acarretadas pela penetração da barbotina nos vãos entre as peças que compõem o molde (tampas com corpo ou duas partes do corpo de um molde). Estas costuras são "cortadas", provavelmente, com o uso de ferramentas como estiletes ou objetos cortantes de metal.

Além disso, as louças no biscoito apresentam dois tipos de marca, inferindo dois modos de realizar os acabamentos de superfície: a primeira são marcas, possivelmente, de esponjas passadas no interior das peças côncavas (canecas, malgas, xícaras, penicos) e no interior e exterior das peças planas (pratos, travessas, pires). No exterior das peças côncavas duas são as marcas: incisões e relevos. As incisões são de dois tipos: formando uma espiral ao redor da peça e na base das mesmas, onde a distância entre as linhas é muito mais próxima, ou incisões formando circunferências eqüidistantes ao redor da peça. Quanto ao que chamo de marcas em relevo, são marcas resultante de uma pressão sobre a peça formando faixas que circundam de modo homogêneo sua superfície, estreitando-se em direção à base. Com exceção das marcas de esponja, com função de alisamento, limpeza e de suavizar as leves arestas criadas pelo corte da costura, as demais marcas são resultado de instrumentos de raspagem, ou seja, causam maior intervenção sobre a superfície das peças ainda cruas. O formato espiralado, principalmente na parte externa da base, sugere a utilização de uma mesa giratória, um torno, sobre os quais as peças eram postas. Assim, a mão do oleiro e a ferramenta ficavam quase imóveis, enquanto que o que girava era o vasilhame. Após o acabamento, as peças eram transportadas para a seção dos fornos, onde eram organizadas dentro das caixas refratárias. As caixas refratárias são, então, empilhadas dentro do forno para a chamada queima do biscoito, que ocorre a uma temperatura entre $1200-1300^{\circ} \mathrm{C}$ (PILEGGI 1958: 180). 
Segue, então, um período de resfriamento dos fornos, à lenha, que não podem ser abertos logo após a queima, por acarretar perigo, não só aos trabalhadores, como a toda a fornada. Depois de abertos, as caixas refratárias são retiradas e as peças no biscoito armazenadas. Daqui podem seguir três caminhos: ir direto à seção de esmaltação, ir para a seção de pintura ou para a seção de marcas. Seguindo diretamente à seção de esmaltação, a peça originará uma louça branca ou com decoração em relevo, ou, ainda, pode ganhar uma decoração em decalcomania. Se for para a seção de decoração primeiro, não conterá marca, e será uma peça com decoração pintada. Se for primeiro para a seção de marcas, poderá ser uma peça branca ou com decoração em relevo, com marca carimbada, ou uma peça pintada que será depois carimbada. Acredito que o carimbo da marca sempre seja aplicado primeiro, no caso de uma peça pintada, para que a manipulação da peça a ser carimbada não borre a decoração já aplicada no biscoito.

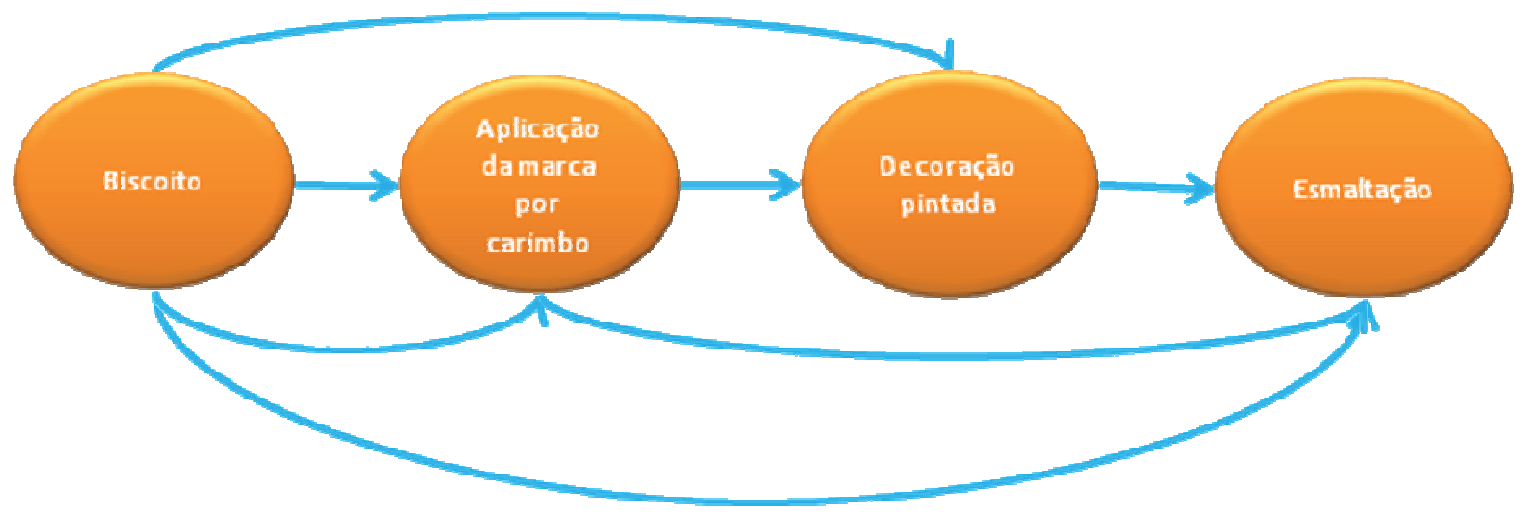

Depois de decorados, ou não, os biscoitos vão à seção de esmaltação ou vidragem. $\mathrm{O}$ sítio Petybon contém inúmeras peças no biscoito com decoração pintada, sem decoração ou com decoração moldada, sobre as quais há o vidrado cru, ou seja, o vidrado aplicado enquanto suspensão aquosa, por imersão, nas peças no biscoito. Os biscoitos, porosos, absorvem a água, seguido de gradual evaporação, ficando sobre a superfície do vasilhame uma cobertura rosada pulverulenta, o vidrado não queimado.

Após estas etapas, as peças vão novamente esperar em estantes de madeiras o momento da queima. Ocorre, então, algo bastante semelhante a primeira queima: as peças são transportadas para a área do forno, organizadas dentro das formas refratárias, que são empilhadas para encher o forno e começar a queima. A diferença aqui está no uso do mobiliário do forno, ou seja, as peças são apoiadas e separadas dentro das caixas refratárias sobre trempes e apoiadores, que impedem que o vidrado funda-se com a superfície refratária ou uma peça 
com a outra. A queima do vidrado é realizada em atmosfera redutora, em temperatura mais baixa, de no máximo $1150^{\circ} \mathrm{C}$ (PILEGGI 1958: 180).

É importante ressaltar que tanto a queima no biscoito como a queima do vidrado envolvem cadeias ligadas à produção, e manutenção para uso mais prolongado, das fôrmas refratárias. Primeiramente, para a queima, as formas são empilhadas no forno. Devido sua irregularidade, o empilhamento não acarreta uma total vedação do interior da caixa pela base da caixa acima. Por isso, a Fábrica produzia roletes de argila refratária que eram postos crus entre a boca de uma forma e a base da superior, para vedar o interior das mesmas, onde estavam as louças. No entanto, com uso contínuo e manipulação, as formas podem quebrar, quebras não tão significativas a ponto de impossibilitarem sua reutilização (o que, se ocorrer, faz com que as formas sigam para a maromba, que produz o chamote que é misturado à nova argila refratária para fabricação de novas formas). Assim, quando partes das formas quebram e caem, os oleiros constroem uma nova parede com roletes superpostos e unidos, sem grande preocupação de acabamento ou união dos mesmos. Por isso, muitas das caixas podem possuir duas técnicas no mesmo corpo: o torneado, técnica de manufatura básica das formas, e o roletado, através do que chamei de "roletes para concerto".

Após a segunda queima, a queima do vidrado, segue um período de espera para que as louças esfriem, quando o forno é, então, aberto e esvaziado. As peças estão prontas para venda, sendo, talvez, armazenadas em caixotes de madeira, dentro dos quais os pratos são usualmente empilhados e as malgas são ou postas umas sobre as outras ou postas uma dentro das outras em graus de volume crescente. A partir daí, os caminhos do mundo do consumo e da aquisição de objetos são inúmeros. Caso ocorra decoração sobre esmalte ou decalcomania na superfície vidrada, aplicar-se-á um decalque, o qual será, novamente, queimado, em geral em forno contínuo, com temperatura ainda mais baixa que nas outras queimas (aproximadamente $600^{\circ} \mathrm{C}$, podendo chegar até $850^{\circ} \mathrm{C}$ em alguns casos).

Observação seja feita quanto ao uso da decalcomania nas faianças finas, onde fica claro uma técnica resultante de uma escolha e não de uma necessidade (KINGERY 1993: 224). A inovação que a faiança fina trouxe foi a de justamente poder ser decorada diretamente no biscoito, na superfície cerâmica, implicando uma única aplicação de vidrado, diferenciando-a da faiança portuguesa, cujos processos de queima e esmaltação em maior número encareciam a produção. O uso da decalcomania, talvez, tenha uma lógica funcional pensada a partir da conjuntura da cadeia de produção, mas do ponto de vista tecnológico ela parece resultar de escolhas mesmo aparentemente paradoxais, pois se havia possibilidade de decoração sobesmalte, com 2 queimas e 1 esmaltação, a decalcomania acarretava 3 queimas (biscoito - 
vidrado - fixação do decalque) encarecendo a peça - se não houvesse um reflexo no barateamento da mão de obra, pouco especializada; a aplicação do decalque é um processo muito mais rápido, já que é apenas a colocação de um "adesivo", do que o de pintura a mão livre, produzindo-se mais peças por dia. Além disso, a utilização do decalque pode estar ligada às opções do mercado por decorações com características mais "industriais", haja visto o contexto da cidade de São Paulo nesse começo de século XX. A decalcomania e outras decorações sobre esmalte são um exemplo claro de escolha tecnológica associada mais a valores simbólicos (LEMONNIER 1993: 3) ou dimensões não-materiais da produção (VAN DER LEEUW 1993: 244) do que a alguma necessidade adaptativa.

Apesar de tratar dos significados dos defeitos de produção e seus posteriores aproveitamentos a posteriori, gostaria de dizer que o sítio Petybon contém muitos produtos da cadeia operatória que podem ter sido encarados como defeitos ou desvios. Estas variantes na cadeia parecem resultar "de procedimentos diferentes respondendo a acidentes, imprevistos e às marcas estilísticas individuais ou mesmo imposições comerciais" (VIANA 2003: 187) - não sendo incorporados, aqui, os dois últimos casos. A maior parte dos defeitos, como pode ser visto no fluxograma a seguir, é gerado na etapa da queima do vidrado. Antes do biscoito, os defeitos surgidos podem ser solucionados ou no acabamento de superfície, quando é possível fazê-lo, ou fazendo com que a peça retorne ao princípio da cadeia e seja, novamente, misturada a pasta. Após a queima no biscoito, entretanto, fica difícil reaproveitar o refugo gerado na cadeia e dar um "fim" aos descartes da produção; por exemplo, misturá-los novamente à pasta das louças alteraria a plasticidade das mesmas, podendo acarretar ainda mais defeitos durante as queimas. No entanto, a Fábrica tentou responder a estes problemas da produção criando algumas soluções que, apesar de não definitivas e de não darem fim a todo o refugo gerado, criaram algumas formas de aproveitamento, mesmo que não conscientemente com esta finalidade, reciclando e re-utilizando as louças. Alguns destes defeitos têm características, como veremos mais à frente, que ainda possibilitariam sua venda e consumo, mas como uma categoria de louça mais barata.

Como apontarei em capítulos seguintes, a Fábrica criou diversos mecanismos a fim de reaproveitar ou descartar as louças que não seriam mais vendidas: lançar à rua para que a população a utilizasse (seja como louças inteiras, sejam os fragmentos para aterrar buracos no barro das ruas ou para realizar brincadeiras), usar os fragmentos no biscoito e as louças como anti-plástico de caixas refratárias e tijolos, e, ainda, usar os biscoitos como suportes para a escrita. O fluxograma seguinte demonstra que os defeitos gerados ao longo da cadeia operatória não significavam o descarte final dos artefatos nos quais estavam contidos, mas, por vezes, a 
entrada dos mesmos em novos contextos e novas cadeias operatórias. Destaquei em vermelho os caminhos que se podem inferir através dos registros materiais.

Um último ponto apontado aqui é o referente ao transporte das peças, durante a produção, para os diferentes setores da fábrica. Diferentemente das cerâmicas roletadas ou das torneadas, onde a maior parte da construção da peça ocorre num mesmo local, a produção das louças na Fábrica acarretava seu transporte para diferentes lugares, onde diferentes indivíduos continuariam o processo da mesma peça, uma das características de uma cadeia de cunho taylorista. Este transporte era feito através de tábuas de madeira, como pude inferir a partir de fotografias da Fábrica e de dados etnográficos. Estas tábuas teriam a função, primeiramente, de transporte de uma quantidade maior de louças do que se fossem utilizadas apenas as mãos, uma vez que as peças são enfileiradas sobre as tábuas. Além disso, quanto menos manuseio, menos possibilidades de gerar perdas na produção, como defeitos resultantes de choques mecânicos durante a manipulação, marcas de dedos, etc. As mesmas tábuas que realizam o transporte são as tábuas nas quais as louças são armazenadas durante a secagem natural, no intervalo entre a queima do biscoito e a esmaltação e entre a esmaltação e a queima do vidrado. Estas tábuas compõem as estantes de armazenamento. Assim, diminui-se ainda mais o contato físico entre o trabalhador e a cerâmica. As estantes são, na verdade, grandes esqueletos nos quais são apoiadas as tábuas com as peças em cima.

Por fim, após os fluxogramas, segue a reprodução de um texto contido no catálogo da Exposição Universal de 1918, documento que indica características da produção, assim como aponta os discursos pelos quais a elite industrial paulista forjou as imagens das fábricas em seus projetos de modernidade para o país e para a cidade, tema que retomarei ao longo da dissertação. Optei pela reprodução do texto na íntegra por ser um documento de extrema relevância para a Fábrica. 
POSSIBILIDADES DE GERAÇÃO DE DEFEITOS AO LONGO DA CADEIA OPERATÓRIA DAS LOUÇAS

DE MESA DA FÁBRICA DE LOUÇAS SANTA CATHARINA / IRFM - SÃO PAULO
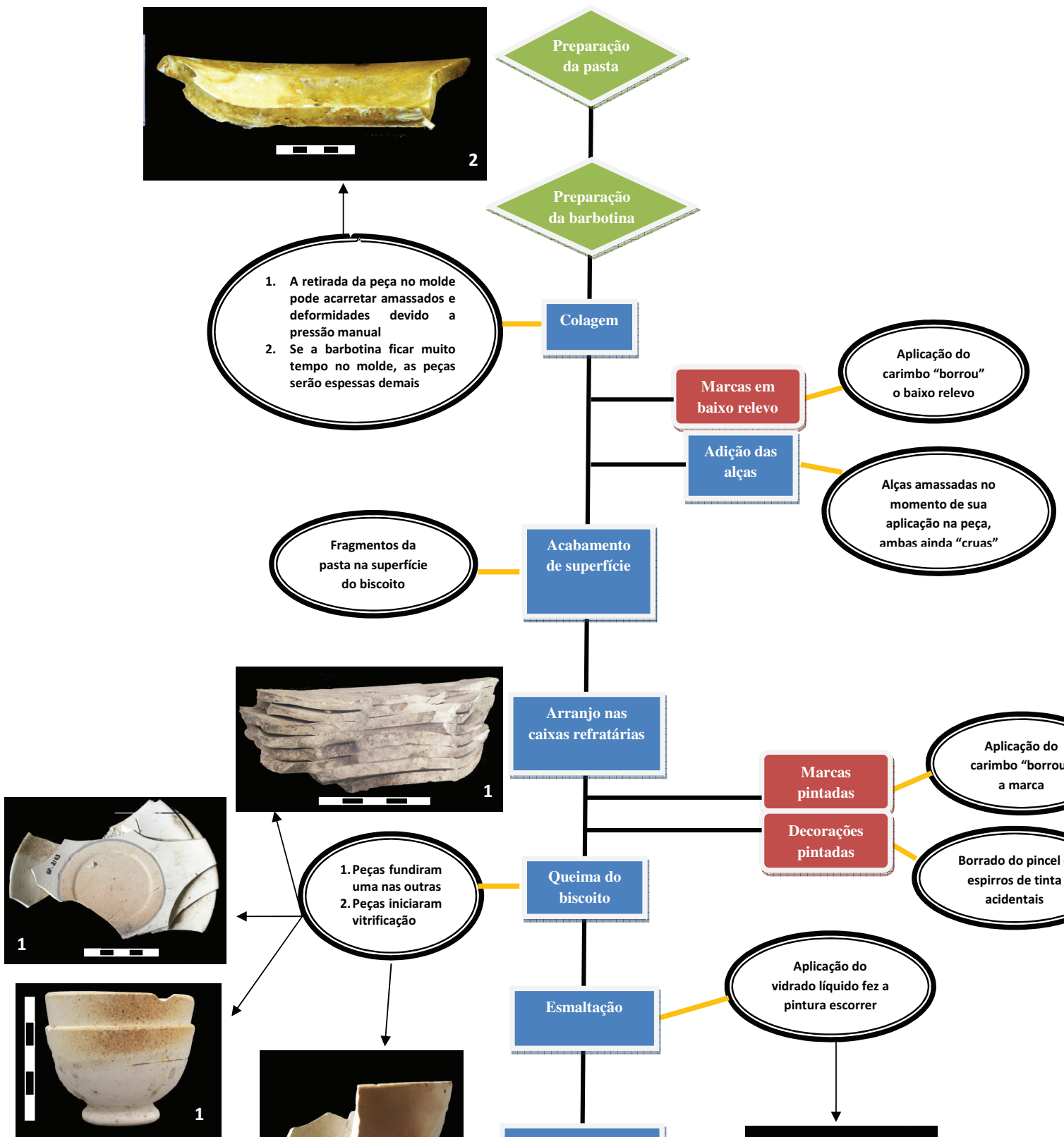

de superfici
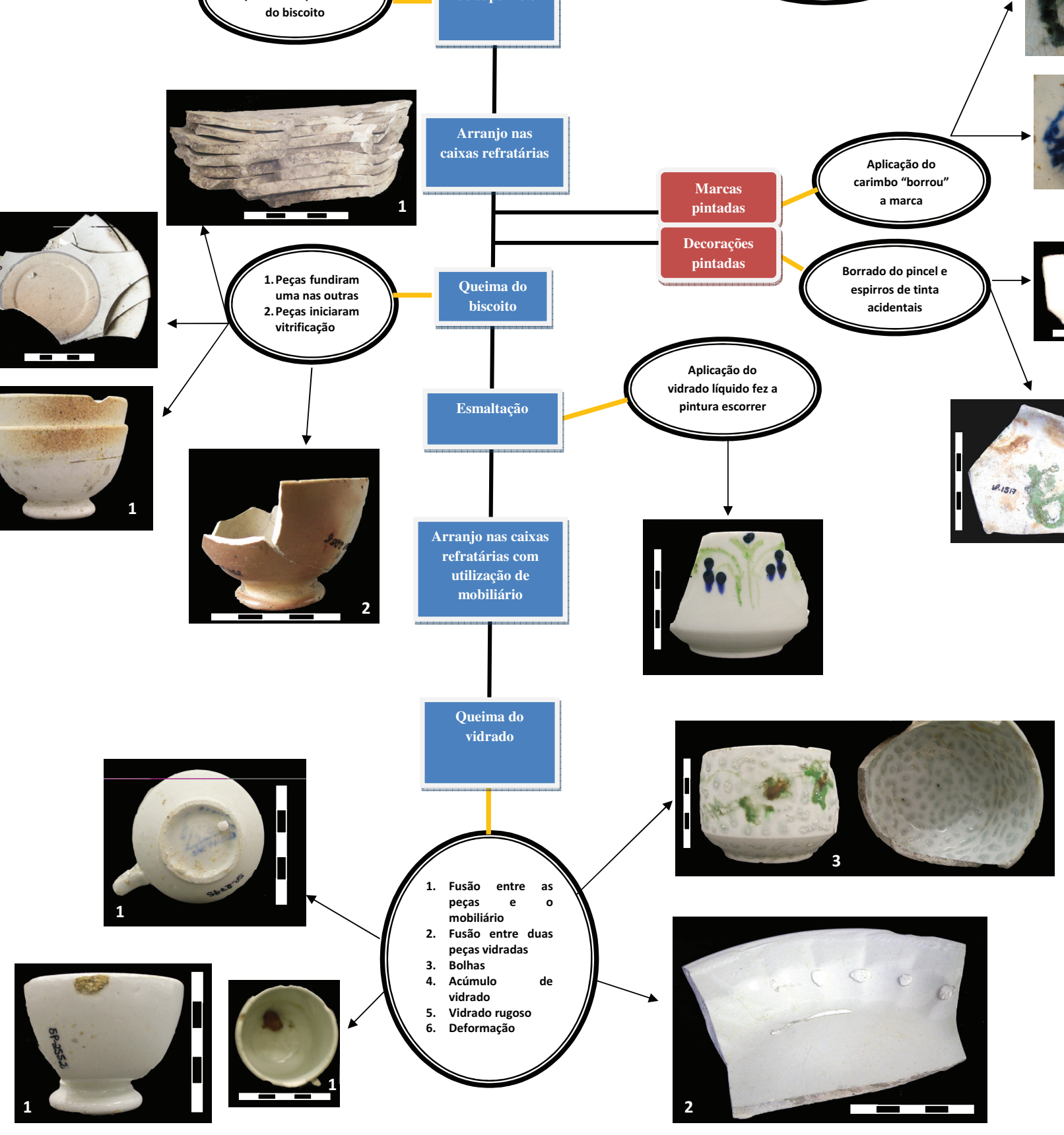
MOMENTOS DE DESCARTE DE ALGUMAS PEÇAS POR DEFEITO AO LONGO DA CADEIA OPERATÓRIA E SUAS RESPECTIVAS POSSIBILIDADES DE REUTILIZAÇÃO NA FÁBRICA DE LOUÇA SANTA CATHARINA / IRFM - SÃO PAULO

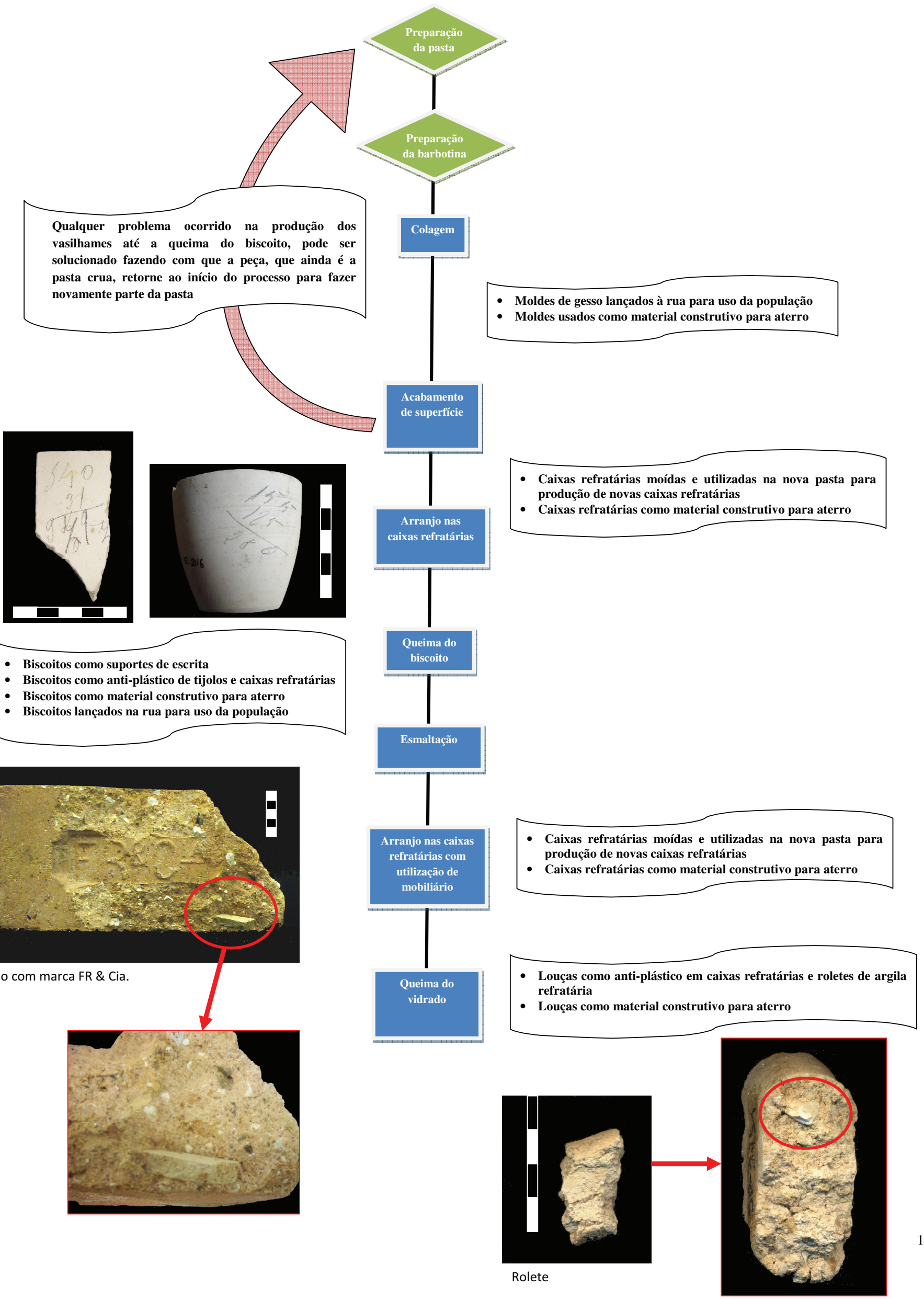


Fábrica Santa Catharina

Rua Amelia
Fagundes, Ranzini \& . $^{\text {ia }}$

Água Branca

Este estabelecimento que é hoje, sem duvida, o maior e o mais importante deste gênero em toda a America do Sul, foi criado pela energia indomavel e pela esclarecida intuição de Romeu Ranzini - um moço italiano que deve tudo o qeu é a si mesmo, aos seus estudos de campo da chimica industrial, ao seu trabalho disciplinado e incançavel - juntos á um vigoroso espírito de iniciativa e á fé inquebrantável no sucesso dos Srs. Fagundes que não duvidaram em dispensar o seu valido apoio á empreza que em cauda das difficuldades techincas apresentadas no inicio afigurava-se como acompanhada por obstaculos insuperaveis.

Penetrando nas vastíssimas construções que constituem o conjuncto da Fabrica Santa Catharina, sente-se a impressa do esforço grandioso, do gosto continuo de energia que foi e é ainda preciso para dotar São Paulo de um estabelecimento deste gênero.

Naquella colmeia em que se desenvolve quotidianamente a actividade de 800 operarios a impressão da força do trabalho vence o espírito. Eis o rumor dos quebradores, dos moinhos, que pulverisam o branco calcareo, dezenas de cylindros preparam o caolim, numerosos e enormes agitadores preparam a primeira massa que, atravez de outras machinas torna-se subtil, extende-se, adquire elasticidade e resistência para em seguida ser adaptada á modellagem. Para esta operação servem centenas de turbinas horizontaes, sobre as quaies a massa guiada pela mão experta do operário, toma a fórma definitiva que se lhe quer dar e transforma-se em prato, tigella, etc., que passam em seguida na grande sala de seccação onde por meio de um systema engenhosissimo de aberturas é mantida uma incessante ventilação.

Depois de conseguido determinado grau de seccação estes productos são introduzidos nas grandes fornalhas das quaes damos aqui a photographia.

Depois de um período de tempo mais ou menos cumprido nestes fornos, que por si só são sufficientes para dar uma idéia da importância do estabelecimento, pois cada um pode conter de 150 á 200 mil peças de louças, os productores passam á operação da esmaltação e envernização para serem em seguida submettidos a nova cozedura, a definitiva, depois de que passam nos armazéns para serem enviados a todas as praças do Brasil e também a alguns mercados do extrangeiro. 
Digno especialmente de lembrança é o facto que todos os trabalhos de modellagem são executados $n$ mesmo estabelecimento, numa secção especial onde artistas modeladores estudam e cada dia cream novos modellos.

Salas especiaes são destinadas às decorações dos productos finos, como vasos, estatuas, taboleiros, castiçaes, e cada dia o incançavel Sr. Ranzini estuda vernizes novos, effeitos decorativos que nada têm a invejar aos productos congêneres de que até hoje o Brasil foi tributário á velha Europa.

Digno de nota a este respeito é o facto que a secção artistica do estabelecimento vae de dia em dia tomando vulto no movimento de conjuncto, pelo bom gosto dos seus proprietarios que não procuram só o lucro, mas que este sabem conciliar com um gosto artístico indiscutivel, para egualar os productos de grande valor provenientes das mais acreditadas fabricas europeas.

Inutil accrescentar que também as industrias accessorias, como a producção de materiaes refractarios, a confecção das mercadorias acham o seu logar no estabelecimento, o que representa na verdade um digno coroamento dos esforços empregados no trabalho pelos Srs. Fagundes e Ranzini, que são a evidente demonstração de quanto passam o trabalho e a iniciativa nesta terra feliz (PICCAROLO \& FINOCCHI 1918: 147-149). 


\title{
3.1.2. Na longa duração da mercantilização e da industrialização: a Fábrica Santa Catharina / IRFM - São Paulo e a instalação das fábricas de faiança fina em São Paulo
}

\author{
... A nossa indústria já alçou vôo seguro buscando seguir a \\ rota dos nossos predecessores de além mar. \\ (Presidente do Sindilouça Francisco Sales Vicente de \\ Azevedo, em Memorial de 20/03/1948)
}

A história da industrialização no Brasil, e na cidade de São Paulo especificamente, é contemplada por uma vasta bibliografia. É debate constante o período do início da industrialização no país, alguns pesquisadores apontando para o final do século XIX, outros para as décadas de 1920, 1930 ou, até mesmo, 1950. Segundo Luz, por exemplo, a década de 70 do século XIX marcaria o início da história da industrialização no país, que, anteriormente, configurava-se por pequenas fábricas que tentavam participar das vantagens sócio-econômicas que o avanço tecnológico proporcionava ao Ocidente (LUZ 1974: 28).

Em geral, a visão que perpassa estes estudos parece ser a formada pelas grandes sínteses de Caio Prado, Celso Furtado, Boris Fausto, Gilberto Freyre e Fernando Novais os quais, a partir da década de 1930, pensando o sistema colonial brasileiro, elaboraram a idéia do sistema exportador de plantation, do grande latifúndio, voltado para o mercado externo, sendo a produção interna brasileira quase nula, já que a função da colônia seria a de consumir apenas os produtos importados da metrópole (NOVAIS 1986; PRADO 1953). Deste modo, após um período de improdutividade, o Brasil, a partir de fins do XIX, teve um boom industrial que marcou uma ruptura e significou uma transformação total na sociedade, visão clássica na qual a economia de subsistência e o mercado inteiro seriam meros apêndices do sistema colonial.

É apenas a partir do final da década de 1970 e 1980, não obstante expoentes anteriores como Amaral Lapa, que uma revisão destas idéias é levada à cabo com maior afinco, acarretando o surgimento de trabalhos como os do grupo de História Agrária da UFF. Maria Linhares (1996), por exemplo, estudando a agricultura no país, procurou demonstrar que a visão plantacionista na historiografia brasileira é uma marca persistente e deveras conservadora que implica numa defasagem na relação que se percebe entre a importância da pequena lavoura e o papel da agricultura de subsistência na Colônia. Começou-se, deste modo, a serem sistematizados estudos sobre a agricultura de alimentos, a pecuária e o comércio de abastecimento. 
Para Linhares, a pequena lavoura e a agricultura tiveram importante papel em torno da questão da ocupação da terra e na organização de trabalhos sob a forma familiar, responsáveis em produzir excedentes e atender, progressivamente, às necessidades dos núcleos urbanos em expansão e das frotas que se dirigiam ao sul e à África (LINHARES 1996: 137). Para a autora, equivoca-se quem pensa que o Brasil viveu de açúcar e nada mais que açúcar e, após o século XIX até 1930, de café e só café. A mandioca, por exemplo, era a segunda (depois do cultivo da cana) dentre as dez maiores culturas brasileiras, segundo estatísticas do século XIX; mandioca e cana persistiram por séculos em sua parceria histórica, levantando, inclusive, questionamentos sobre o peso da participação indígena no meio mameluco (LINHARES 1996: 138). Além disso, a associação entre produção de alimentos e pecuária, durante o Brasil Colônia, foi responsável por uma enorme movimentação de renda, impulsionando a economia do país; coisa que a teoria da plantation, exportadora de grande propriedade, acabou camuflando.

Comento sobre estas novas interpretações em relação às dinâmicas econômicas no Brasil Colônia, porque elas estão diretamente relacionadas às abordagens em torno dos argumentos de "pobreza", "isolamento" e "auto-suficiência" que foram forjados sobre São Paulo. Estes argumentos tentaram delimitar uma modernidade e um período de progresso opostos a uma São Paulo colonial estática, com base nas visões clássicas do Brasil colônia e do sistema colonial, o que acarretou uma periodização da história da cidade "que enxerga uma fase de decadência, pobreza e isolamento no período que vai do século XVIII até o advento das estradas de ferro, da plantação intensiva do café e dos movimentos imigratórios mássicos, subsidiados pelo Estado" (MOURA 2005: 15). Deste modo, com base na tese do isolamento paulista no período colonial, em relação aos "centros dinâmicos" no Nordeste ou em Minas, foi forjada a imagem da pujança paulista no século XX, que ora era vista como a "locomotiva da nação" (LOVE 1984), ora "explorando a não inserção da região paulista nos mecanismos exploratórios do Antigo Sistema colonial", apontando-se "para o dinamismo paulista na fase pós-independência com o café e a posterior industrialização" (BLAJ 2000: 242).

A crítica a esta postura e às abordagens de uma paulicéia moderna surgida com o final do XIX e começo do XX, sob o prisma braudeliano da longa duração, mostram que a fundação da Fábrica de Louças Santa Catharina, em São Paulo, e de outras fábricas, na realidade, fazem parte de um longo caminho de mercantilização da metrópole (BLAJ 2001), associada a seu caráter movediço (MOURA 2005), ao qual, com o tempo, vieram se somar, 
aos modos de produção presentes na cidade, o sistema de fábrica e as indústrias. Por isso, não me posiciono favoravelmente a idéia de um boom industrial, mas sim de que as indústrias e fábricas são parte de um processo mais longo que inseriu a cidade na esfera capitalista da mercantilização a partir do século XVIII.

Os trabalhos de Ilana Blaj foram marco nas interpretações sobre a mercantilização do Brasil, e de São Paulo, no período colonial, mostrando que uma análise mais pormenorizada do processo no país desmente a aparente "pasmaria" da economia colonial e de inícios do Império. "Estudos mais recentes sobre a vila de São Paulo no período colonial têm destacado seu grau de mercantilização crescente e a formação de uma sociedade rigidamente hierarquizada" (BLAJ 1998), e, nesta linha, Blaj mostra que a partir, pelo menos, do século XVIII, assiste-se a sedimentação de uma elite paulistana que concentra em suas mãos terras, escravos, gado, produção agrícola e comércio, "e que, através das relações patrimonialistas no âmbito da Coroa Portuguesa, consolida-se progressivamente no poder" (BLAJ 1998).

As inúmeras queixas registradas na documentação escrita sobre São Paulo colonial referentes, por exemplo, à falta de víveres produzidos na região, que são, usualmente, encaradas como indícios da pobreza de São Paulo seriam, segundo a autora, indicativos de toda uma produção local e regional e de todo um movimento mercantil que se orientou, gradativamente, a uma lógica de mercado, fato acelerado pela articulação entre a cidade e as áreas mineradoras, que ampliaram as possibilidades de comércio, especialmente a partir da terceira década do século XVIII (BLAJ 1998). A dinamização da economia paulistana seria parte do contínuo processo de mercantilização de São Paulo, que, no período, passa a manter um grande comércio de exportações e importações através do porto de Santos, abastecendo não apenas áreas interioranas e bairros rurais, como também Minas Gerais, Cuiabá e Goiás, e fornecendo gêneros às capitanias da Bahia e do Rio, fazendo com que, nas palavras de Blaj, a antiga vila de Piratininga se tornasse "um importante pólo comercial, estendendo, cada vez mais, as redes de sua teia mercantil" (BLAJ 1998).

A Arqueologia também corrobora estas novas abordagens, notadamente em suas pesquisas sobre universos produtores de cerâmica da cidade e seus arredores. Zanettini, por exemplo, mostra como não houve uma ruptura tão grande, como nos fez crer a historiografia, entre um mundo pré-industrial e um pós. É claro que as indústrias trouxeram transformações, não há como negar, mas São Paulo não acordou de um longo sonho de abandono econômico. Pelo contrário, por toda a região, a movimentação de mercadoria gerava lucros e rendas e inseria a cidade num esquema maior de mercantilização da economia do país em sua relação 
ao restante do mundo. A produção de cerâmica local/regional sugere uma indústria local que atendia a demanda de uma população crescente e cada vez mais necessitada destes produtos (ZANETTINI 2005).

Semelhante idéia foi apresentada por Morales para a Jundiaí do século XVIII. Segundo o mesmo, durante este período, com o crescimento da demanda dos aglomerados urbanos, criou-se a necessidade de abastecimento das vilas e cidades, e um dos produtos de grande produção local era a cerâmica. É possível que durante o século XVIII, a cerâmica encontrada nas áreas do entorno de São Paulo possuísse duas micro-divisões, a produzida nos aldeamento e a confeccionada em propriedades rurais (MORALES 2001: 181). Coexistiriam, assim, produções cerâmicas voltadas para a venda e para consumo próprio; isto teria perdurado pelo menos até o século XIX, quando uma população indígena e mestiça intensificou a produção cerâmica para uma demanda, por produtos mais baratos, por parte da população com menor poder aquisitivo (MORALES 2001: 180).

Com o século XIX, foram se reunindo, em São Paulo, as condições necessárias ao desenvolvimento do setor comercial e de indústrias destinadas a substituir a importação de bens de consumo pela produção nacional (ÉRNICA 2004: 168). Além do mercado de capitais, trabalho e circulação de moeda na economia, desenvolveu-se o setor de infraestrutura (malha ferroviária e usinas de energia elétrica), e a concentração demográfica, na capital e no interior, gerou demanda por bens de consumo semiduráveis e por alimentos. Com isto, a produção cerâmica e as olarias foram trazidas para dentro das fábricas e sua estrutura começou a ganhar moldes mais capitalistas. Segundo Érnica (2004: 169-170), no estado de São Paulo, as indústrias foram criadas primeiro no interior e só depois se concentraram na capital, fazendo com que a cidade, na década de 1910, fosse o maior pólo industrial brasileiro, responsável por mais da metade da produção nacional. No entanto, caminhos inversos fizeram as fábricas de louças brancas no estado: capital rumo ao interior (PEREIRA 2007).

Com a $\mathrm{I}^{\mathrm{a}}$ Guerra Mundial, as fábricas brasileiras passaram a exportar alimentos e tecidos para os países em conflito, e o governo deu início a uma política de substituição das importações, favorecendo os manufaturados nacionais. Por isso, entre 1914 e 1920, surgiram cerca de seis mil novas fábricas no estado, trazendo consigo novos elementos do cenário político, como as organizações operárias e as tensões das greves (MARANHÃO 1994: 63).

A implantação da indústria de cerâmica branca, no Brasil, apresenta-se dentro desta conjuntura, associada ao que se poderia chamar de uma gradativa adoção dos meios de 
produção capitalistas à produção cerâmica. A origem da cerâmica como atividade industrial, em São Paulo, se deu a partir do final do XIX e início do século XX, relacionada, portanto, à expansão do mercado interno, aumento da imigração e urbanização e expansão da economia cafeeira (BELLINGIERI 2003: 5). Não se deve esquecer, contudo, que uma produção cerâmica com fins comerciais já existia e vinha se fortalecendo na cidade, para abastecer um mercado local ou regional, desde a Colônia e por todo o Império (BELLINGIERI 2004; ZANETTINI 2005).

Foi a rápida proliferação de olarias que representou o marco inicial da indústria cerâmica e de sua associação ao sistema fabril, em São Paulo; olarias já se faziam presentes quase em todas as cidades e núcleos urbanos do estado, desde antes das últimas décadas do século XIX (ZANETTINI \& MORAES 2005). O número de olarias no estado está ligado não apenas ao aumento da população, urbanização e mercado interno, criando grande demanda por produtos cerâmicos, mas também à disponibilidade da matéria-prima básica, a argila (BELLINGIERI 2003: 7). Na capital, as cerâmicas estavam quase todas localizadas ao longo da várzea do rio Tietê, nos bairros da Água Branca e Barra Funda.

No começo do século, toda uma legislação em torno do ofício de oleiro começa a ser delineada, indicando um reconhecimento da profissão, que culminará, como veremos adiante, com a greve de 1917 e a fundação da Liga dos Ceramistas. Em 1907, por exemplo, o cargo criado pela municipalidade de "fiscal de rios" tinha a incumbência de "impedir a extração de 'barro para cerâmica nas várzeas do Bom Retiro, Catumbi, na parte edificada do bairro do Peri e nos lugares onde essa extração for permitida, quando não haja licença prévia ou quando as escavações possam prejudicar a saúde publica'; designar onde cada oleiro ou proprietário de olaria poderá extrair barro e garantir que fizessem isso sem o 'esburacamento' da várzea" (JORGE 2006: 36-37). O impacto das valas de extração de argila ao longo do leito do Pinheiros e do Tietê levou, inclusive, à proibição da instalação de olarias próximas ao perímetro urbano em 1913 (JORGE 2006: 119) - fato que pode ter influenciado na escolha do local de implantação da Santa Catharina. Era grande o número de olarias na cidade e muitas das fábricas de louça branca foram instaladas em locais próximos de antigas olarias de cerâmica. A própria Fábrica Santa Catharina estava muito próxima da Cerâmica Paulista, instalada na Água Branca, em 1893, pelo imigrante português Joaquim Ferreira, que fabricava cerâmica torneada (BELLINGIERI 2005). Para uma visão mais detalhada da evolução dos estabelecimentos cerâmicos em São Paulo, nos séculos XIX e começo do XX, conferir Bellingieri (2003, 2004, 2005). 
Com o crescimento das fábricas no período XIX-XX, e suas construções em alvenaria, com tijolos aparentes, houve forte impulso por novas olarias. "Nas várzeas, inúmeras olarias encontravam o barro utilizado na fabricação das telhas, tijolos e manilhas que abasteciam os infindáveis canteiros de obras paulistanos" (JORGE 2006: 57). Este novo impulso, somado à tradição de olarias presentes na cidade de São Paulo, desde muito tempo, produziu uma mãode-obra que manipulava com intimidade a argila e a produção cerâmica, que pode, e foi, aproveitada pelas fábricas de louças posteriores, através da contratação desses brasileiros para trabalhar com a faiança fina, somados aos estrangeiros.

A própria região da Água Branca, no bairro da Lapa, onde estava instalada a Fábrica, no final do século XIX era um bairro tido como oleiro, com várias olarias e locais de extração de argila. Inúmeras olarias de tijolos existiam no local como a de Felisberto Migliani (1887), a de Griselho Ginondo (1885), de Maralino Gerard (1885), Manoel José Ferraz (1885), Pensimini Paulo (1885) e Zoelli Zunga (1885) (MAESIMA 1997). A planta geral da cidade de São Paulo de 1914, produzida pela Comissão Geographica e Geológica, onde encontramse marcadas as fábricas do período, informa que existiam 10 fábricas de louça de barro e 3 de cerâmica, sendo que na Água Branca estão marcadas 4 fábricas na categoria cerâmica, ladrilhos, cal, cimentos ou outros materiais de construção e 2 fábricas na de vidros, louças de barro ou ferro esmaltado, além de uma fábrica na categoria azeite, óleo, cera, resinas ou vernizes. A Fábrica Santa Catharina, marcada como fábrica de cerâmica, aparece na esquina da rua Fábia com Aurélia.

A Água Branca também se configurou, até meados do século XX, como local de caça de pequenos animais em seus restos de matas (JORGE 2006: 100). Fora caminho dos tropeiros no século XVIII, e entra no século XX como um bairro urbano da cidade de São Paulo, onde a São Paulo Railway chegou em 1899. Com a transferência da São Paulo Railway da Luz para a Lapa, em 1898, o bairro teve sua paisagem urbana e vida modificada, caracterizando-se como pólo de atração de mão-de-obra (SEGATTO 1988: 27). A partir do final do século XIX, se instalaram ali a Vidraria Santa Marina (1896), a Fábrica de Tecidos e Bordados Lapa (1913), a Santa Catharina, a Fiat Lux (1919) e etc. A localização da primeira fábrica de louças da cidade neste bairro, especificamente, me fez pensar que seu mercado consumidor era não apenas o do próprio centro urbano, mas também o resto do estado e do país, já que a Lapa era porta de entrada obrigatória para quem vinha do Oeste, de Jundiaí e Campinas (MENDES 1958: 352). 
Quanto à produção de louça em faiança fina no Brasil, em geral, as indústrias de louça branca começaram a surgir um pouco mais tarde, já no século XX, fruto de uma sociedade cuja demanda cresceu por estes produtos, que tiveram sua produção impulsionada, principalmente, no contexto da I Guerra, com a drástica redução das importações e o incentivo à produção nacional. Falo, porém, da cerâmica como uma atividade do setor fabril, o que corresponde, também, as primeiras produções de louça branca em moldes industriais. Entretanto, já se tentou fazer louça no Brasil, a exemplo da muito comentada tentativa de João Manso Pereira que procurou produzir porcelana, no século XVIII (BRANCANTE 1981). Brancante aponta, igualmente, para o século XIX, em Minas Gerais, a tentativa da Cerâmica Nacional, em Caetés, fundada, em 1893, com o objetivo de "produzir artigos finos visando a porcelana" (BRANCANTE 1975: 64). Para o período de 1903-1921, o autor fez um levantamento documental que apontou para um possível "fabrico de peças utilitárias em porcelana em Caeté, de forma industrial" (BRANCANTE 1975: 64).

Ainda anterior a Santa Catharina houve, a Fábrica de Louças Colombo, fundada no Paraná, em 1902 (fundada no final do século XIX, mas que só começou a produzir cerâmica branca a partir de 1902). A Fábrica também teve fases (1902-1909 e 1921-1926), que variaram de acordo com seus proprietários - italianos e alemães - e contou com a presença de técnicos trazidos da Europa e de "gente da terra" (CARNEIRO, s/d: 13; MORALES 2008). Possuía 3 fornos, 1 para cozimento e 2 para queima do vidrado, alcançando uma temperatura de $1200^{\circ} \mathrm{C}$. O interessante desta fábrica é que ela está inserida, muito fortemente, na conjuntura do fim da abolição, e as técnicas de coerção dos trabalhadores e operários são bem interessantes, pois, diferentemente, das estratégias de racionalização do trabalho - como o taylorismo e o fordismo, bastante presentes na Santa Catharina -, a Colombo contratava até feitores em um regime de trabalho com claras alusões ao sistema escravista.

A Santa Catharina, no entanto, foi a primeira fábrica a produzir louças em grandes quantidades, industrialmente, a saturar o mercado com milhares de produtos em série. A fábrica produziu, em faiança fina, vasos, pratos, tigelas (malgas), canecas, xícaras, pires e louça sanitária. Segundo Bellingieri (2004: 29), a partir de meados da década de 1920, a empresa passou a produzir também velas filtrantes, a base de caulim, destinadas, por exemplo, ao Instituto Butantã, para filtros especiais para a fabricação de soros antiofídicos. A Carta Patente (Coleção Ranzini, Museu Paulista) de 28 de Fevereiro de 1912 mostra que a Fábrica inaugurou um novo processo, no Brasil, com uma nova pasta e com novas tecnologias para produzir artefatos em louça branca: 
... para provar que se acha em uso effectivo nesta Republica a invenção de um novo processo de fabricação de louça branca fina, esmaltada e decorada, ladrilhos e artigos semelhantes.

A Fábrica de Louças Santa Catharina foi, posteriormente, comprada pelas Indústrias Reunidas Fábricas Matarazzo (IRFM), tendo funcionado entre 1913 e 1937. A compra pela IRFM marca o início de uma nova fase na Fábrica, que por isso pode ter sua cronologia dividida em dois períodos: 1913-1926 e 1927-1937. A Fábrica Santa Catharina foi originalmente fundada por 5 sócios, quatro deles da família Fagundes (dentre os quais o majoritário era Euclydes Fagundes), e Romeo Ranzini. A Fábrica, fundada na Lapa, entre as ruas Coriolano, Fábia e Aurélia, ganhou este nome, segundo Miriam Ranzini (nora de Romeo Ranzini), devido à estátua de uma Santa, Santa Catarina, que veio com a família Ranzini da Itália para o Brasil. Santa Catarina é hoje uma das padroeiras da Europa, além de padroeira da Itália junto a São Francisco de Assis; a santa refere-se à Catarina de Siena, a 24 a filha de um tintureiro, nascida em Siena, na Itália, que fez parte da Ordem de São Domingos desde os 15 anos e participou do Grande Cisma do Ocidente no século XIV. Foi canonizada pelo papa Pio II, no século XV, declarada segunda padroeira de Roma no século XIX, por Pio IX, e tornouse padroeira da Itália, em 1939, por Pio XII.

A partir da década de 1920, a Fábrica entrou em algum tipo de crise devido às taxas alfandegárias, à Revolução de 1924 e ao custo da energia elétrica, o que a teria levado, após um período de hipoteca, a ser comprada pela IRFM (PEREIRA 2002: 31). A partir da compra oficial, efetuada em 1927, a Fábrica passou a ser conhecida como Fábrica de Louças da Água Branca. Conta-se, neste processo, também com a morte de Euclydes Fagundes, justamente em 1926, o que colaborou para a venda da Fábrica, uma vez que, como principal administrador e sócio majoritário, passou as ações à sua esposa, Adélia, que não quis continuar com o negócio. O significado da presença dos Matarazzo na Fábrica, antes da compra oficial da mesma, ainda é bastante obscura. É possível que a IRFM fosse responsável pela distribuição das louças da Santa Catharina a estabelecimentos comerciais, ou que eles mesmos as comercializassem e cobrassem pelo transporte e armazenamento.

Abro um parêntese aqui para ressaltar que apesar do nome, não existe uma marca de louça, um selo, "Fábrica de Louças da Água Branca" (pelo menos até hoje não se tem notícia disso); era um nome "fantasia" do local, pois todas as louças referentes a essa fábrica são marcadas com "IRFM - São Paulo". O mesmo parece ter ocorrido com a Fábrica de Louças Cláudia, em São Caetano, que, adquirida pelos Matarazzo em 1935 (VICHNEWSKI 2004), 
vem selada como "IRFM - São Caetano". A planta abaixo, de uma fachada da fábrica, mostra o nome "ficção" pelo qual a Fábrica ficou conhecida pós-1927:

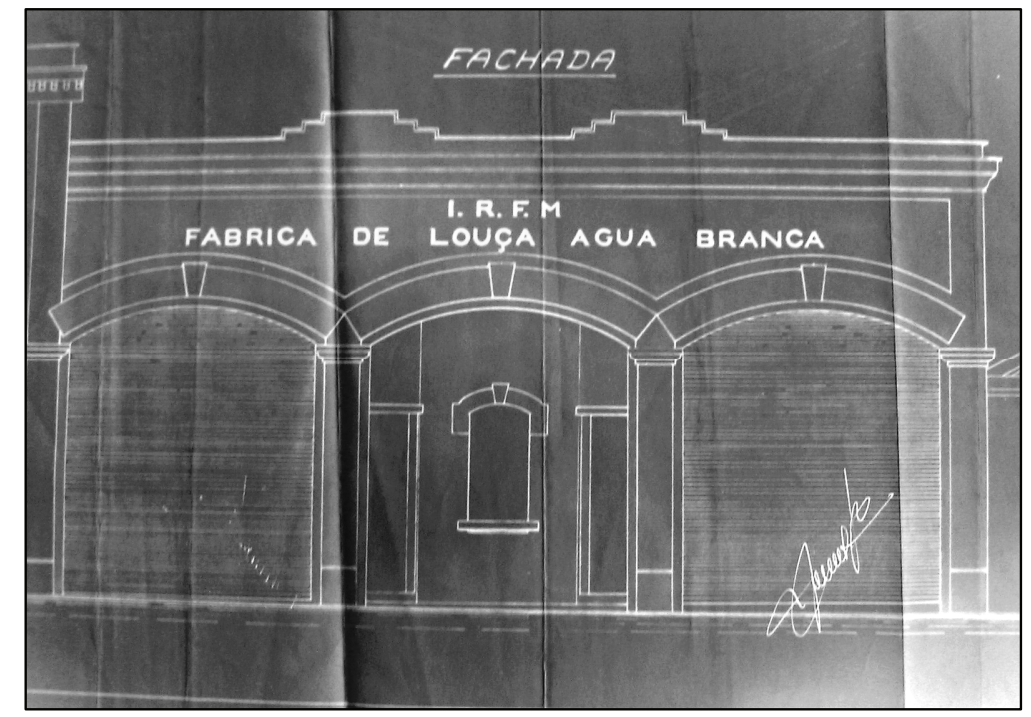

(Acervo do Arquivo Geral/ DPH/SMC/PMSP)

Em 1922, ano da Semana da Arte Moderna, da crise do café, da alta na inflação e de um abalo sísmico (AMERICANO 1962: 207), a Fábrica levou seus produtos à Exposição Internacional do Rio de Janeiro, na qual ganhou o grande prêmio. Segundo o depoimento de Miriam Ranzini, o período áureo da Santa Catharina foi o de 1918-1926, apesar da crise acarretada pelas taxas alfandegárias e o aumento da energia elétrica - assim como outros ramos industriais em São Paulo, a Fábrica utilizou energia a vapor para as máquinas, adotando, em data ainda imprecisa, posteriormente, energia elétrica para iluminação dos galpões ou mesmo como força motriz (PEREIRA 2007: 60). Neste mesmo período, também sofreu impacto da Revolução de 1924, que acabou afetando a produção (ZANETTINI ARQUEOLOGIA, 2003), já que a Fábrica teve suas atividades paralisadas:

Em 1924, a chamada Revolução do Isidoro (...) A Indústria ficou paralisada. Em alguns bairros, como a Mooca, o Belenzinho, os danos foram de grande monta. A fábrica Santa Catharina não sofreu graves danos, teve apenas suas atividades paralisadas... (VICENTE DE AZEVEDO apud PEREIRA 2007: 60). 
Em 1924, São Paulo sofreu ocupação dos militares entre 5 e 28 de julho quando as forças rebeldes tomaram de assalto o quartel da força pública, e várias pessoas não conseguiram chegar ao trabalho devido ao arame farpado espalhado pelas ruas (BORGES \& COHEN, 2004: 297). A tomada imediata das estações de trem e das entradas e saídas da cidade, provavelmente, dificultaram a ida dos trabalhadores e o escoamento da produção; a população, num dado momento, acabou saqueando a cidade e o governo, então, bombardeou São Paulo (BORGES \& COHEN, 2004: 300-302).

A partir da década de 1920, a Fábrica parece ter entrado em crise devido aos problemas já apontados acima (taxas alfandegárias, a revolução de 1924 e o custo da energia elétrica), o que teria colaborado à compra pela IRFM (PEREIRA, 2002: 31), quando a Fábrica passou a ser conhecida como Fábrica de Louças da Água Branca. Com certeza as Indústrias Reunidas a estavam pressionando, já que n'O Estado de São Paulo de 01 de Julho de 1922, foi publicado o anúncio, não muito amigável, que segue abaixo:

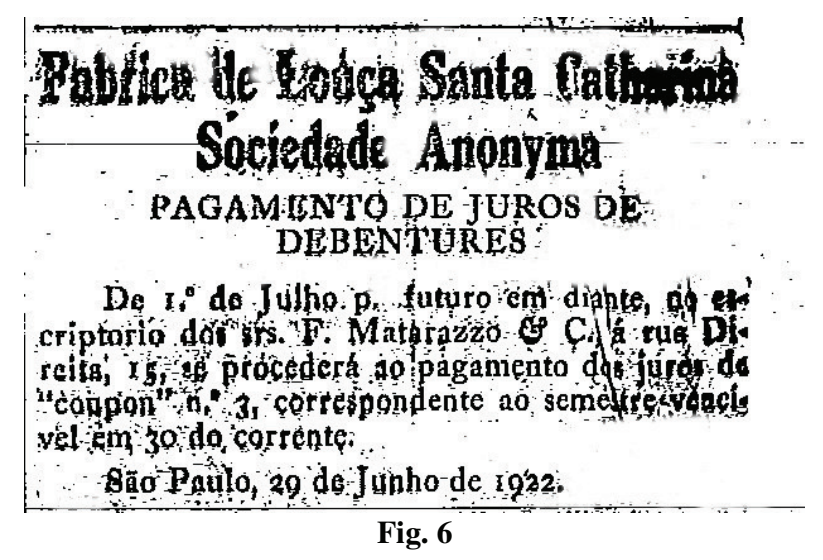

Em 1918, os Matarazzo já aparecem como agentes da Fábrica. Um organograma, montado, em 1925, com as empresas relacionadas à IRFM, mostra o complexo de fábricas das quais eram donos na época, na Água Branca, onde sua relação com a Fábrica Santa Catharina aparece como a de "agentes" (COUTO 2004), ou seja, a IRFM vendia os produtos da fábrica retendo para si a diferença entre o preço por que comprava e o preço da venda, isto é, eram uma espécie de intermediário em negociações mercantis (HOUAISS 2001). Isto configura o movimento clássico de alguns industriais paulistanos de monopolização, especialmente em relação aos bens de consumo pessoal (DE DECCA 2004: 128), gerando revolta dos operários e consumidores médios urbanos. Vilas operárias dos Matarazzo 
continham lojas que vendiam apenas seus produtos, assim como alguns salários eram pagos, em parte, com produtos de suas fábricas. O jornal operário, O Combate, de 14/03/1929, sob a voz do "revolucionário" Cabanas, traz:

Matarazzo, Gamba, Crespi, toda essa quadrilha que possui o monopólio e o "trust" dos gêneros alimentícios e de primeira necessidades, dos tecidos e das bebidas nacionais e até estrangeiros, estão fazendo do Brasil o que bem entendem e com uma petulância irritante, auxilidados pelos respectivos consulados e embaixadas... (DE DECCA 2004: 131) 


\section{INDÚSTRIAS REUNIDAS F. MATARAZZO - $1925^{*}$}

São Paulo Rua Direita no 11

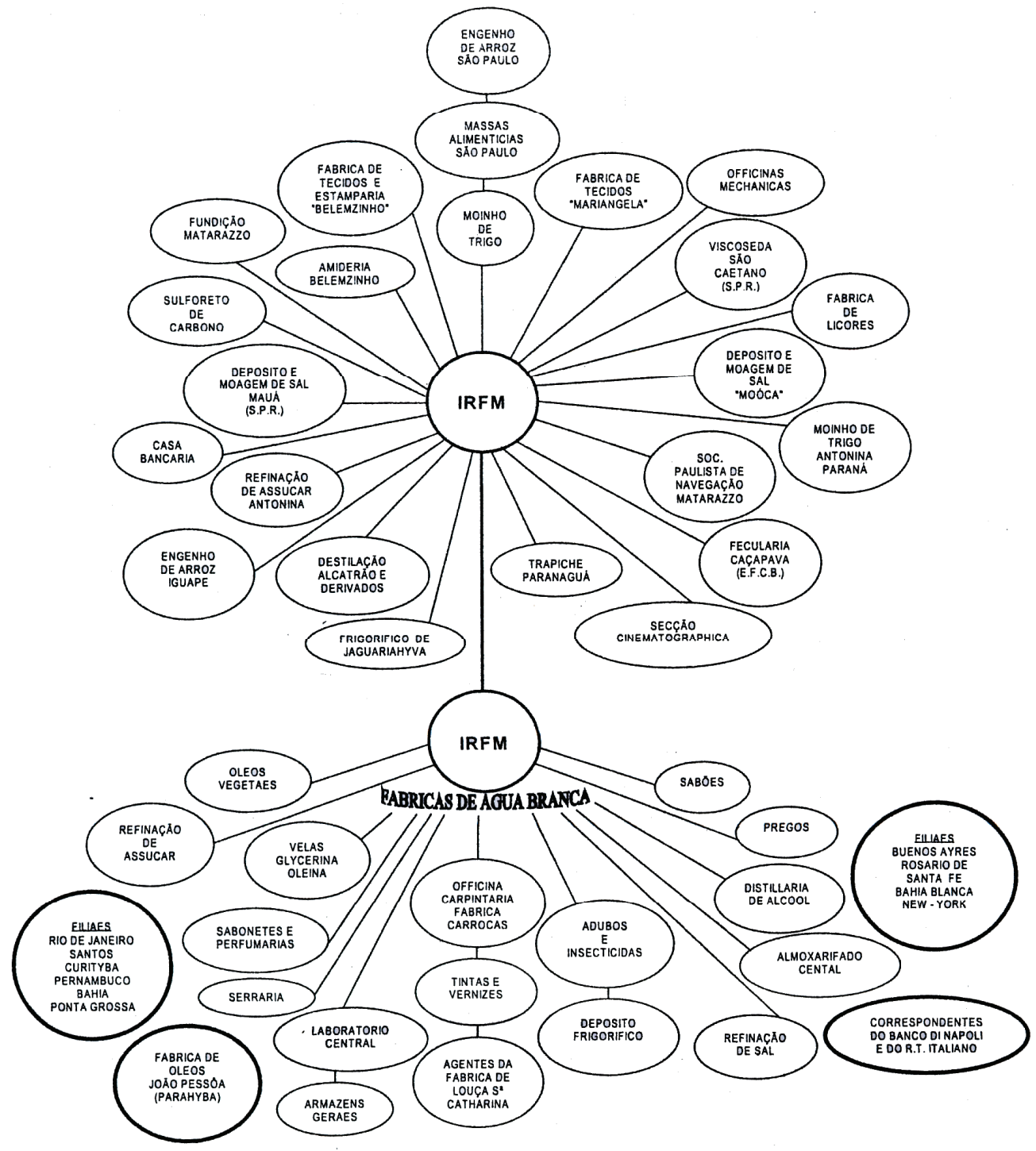

(COUTO 2004)

Após passar ao controle oficial dos Matarazzo, no final da década de 1920, a IRFM inicia uma série de obras na Fábrica e começa a diversificar sua produção (louça sanitária e azulejos). No ano de 1937, a produção de louças da IRFM (já focada mais em azulejos e louças sanitárias) cessa e dá lugar a Fábrica de Biscoitos Petybon, que funciona no local até a década de 1980. Aparentemente, para dar lugar a esta nova unidade fabril, montanhas de 
louças estocadas ou jogadas nos fundos da fábrica foram utilizadas para a construção de um aterro, o sítio Petybon.

A Fábrica, inicialmente, ocupava um terreno de $36 \mathrm{mil} \mathrm{m²}$, com área construída de 15 mil m². Apesar disso, o Registro de Imóveis da Capital, de 1931, registra que a Fábrica possuía $26.755 \mathrm{~m}^{2}$ e de área coberta $19.266 \mathrm{~m}^{2}$; isto porque sofreu inúmeras reformas ao longo de sua existência. Segundo Pereira (2007), as obras de ampliação se tornaram essenciais ao funcionamento da Santa Catarina, tendo, no início dos anos 1920, a mesma sofrido reformas para ampliar sua capacidade produtiva através de mais e maiores depósitos de matéria-prima, novos fornos e mesmo para verticalização:

E por isso mesmo estão se realizando importantes obras para a construção de naus as seguintes dependências: Um edifício de dois andares (...) Um outro salão de grandes dimensões será construído especialmente destinado ao encaixotamento de louça... (apud PEREIRA 2007)

Já na fase Matarazzo, as "remodelações concentram-se em pontos afastados das edificações mais antigas (...) as plantas localizadas revelam a expansão do conjunto fabril em direção aos fundos do terreno" (PEREIRA 2007: 61). O projeto da construção original da Fábrica foi trazido por Ranzini da Alemanha, feito por August Reissmann, sendo, depois, ampliado de acordo com o desenvolvimento da mesma, com obra iniciada em 1912. Segundo Ranzini, a Fábrica era composta por um

Terreno com $36.000 \mathrm{~m}^{2}$, com frente para a Rua Aurélia e limitada pela Rua Coriolano, Rua Fábia e nos fundos pela Rua Catão, na Vila Romana, no Bairro da Lapa. A construção dos primeiros pavilhões, iniciada em 1912, foi concluída nos fins desse ano. O projeto foi fornecido pela firma August Reissmann, fabricante do maquinário que Ranzini adquiriu por ocasião da viagem à Itália.

Abaixo, duas fotografias de visões gerais e externas da Fábrica e uma fotogrametria aérea. A primeira publicada no catálogo da Exposição Universal de 1918 (não necessariamente sendo de 1918) (PICCAROLO E LINOCCHI 1918) e a segunda, sem data, em documento produzido pela própria empresa (PEREIRA 2007: 65). Percebe-se o destaque, 
em ambas as fotos, que se quis dar a imponência da Fábrica meio a um ambiente "natural", quase que selvagem, praticamente sem vizinhos:

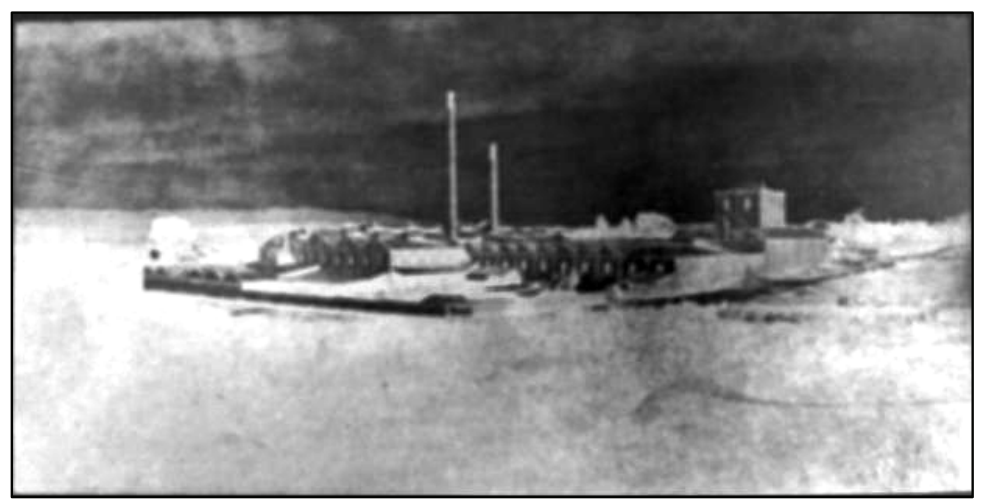

(PICCAROLO \& LINOCCHI 1918)

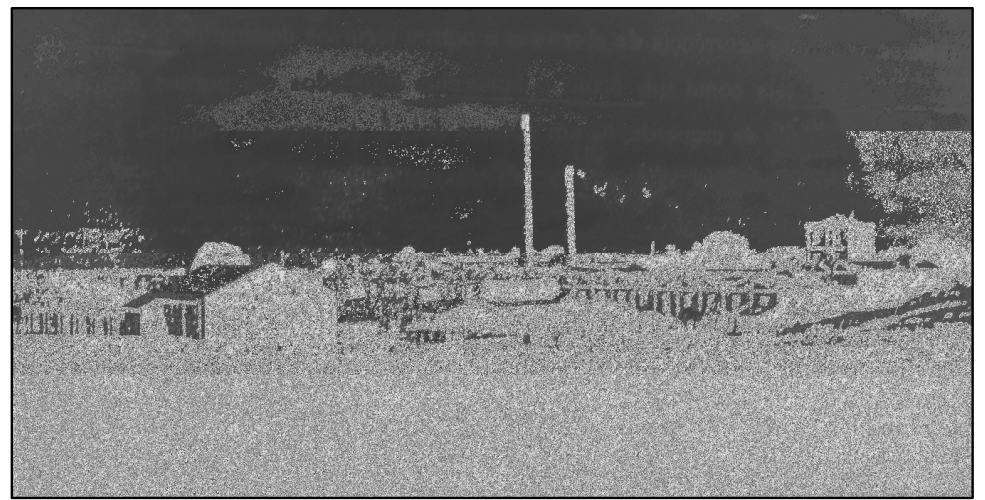

(PEREIRA 2007)

Segue, igualmente, planta baixa da Fábrica dos anos 1930, disponível no acervo do DPH, além de dois desenhos de fachadas ainda visíveis quando da época do resgate, as quais correspondem a edificações internas ao terreno, não voltadas para a rua. A planta baixa, se comparada a aerofotogrametria que apresentei no Capítulo 1, permite perceber que o número de galpões aumentou consideravelmente entre os anos 1930 e 1950 e que o "Forno" sobrepõem-se ao que é uma chaminé na foto aérea. Também indica que a área de maior potencial arqueológico, o vazio entre a rua Coriolano, Fábia e o "Forno", não possuía construções. 